$$
\text { DOE/CE/40887--T1 }
$$

$\mathrm{DOE} / \mathrm{CE} / 40887--\mathrm{TI}$

DE92 013619

\title{
FOUNDRY ENERGY CONSERVATION WORKBOOK
}

\section{Fall 1990}

$$
\text { FGO1-89CE } 40887
$$

Project Co-Sponsors: AMERICAN CAST METALS ASSOCIATION

ALABAMA CAST METALS ASSOCIATION CALIFORNIA CAST METALS ASSOCIATION FOUNDRY ASSOCIATION OF MICHIGAN PENNSYLVANIA FOUNDRYMEN'S ASSOCIATION WISCONSIN CAST METALS ASSOCIATION

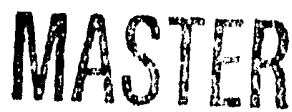




\section{Acknowledgments}

Funding for this research project was provided by the U.S. Department of Energy through a contract with the California Cast Metals Association (CCMA).

Contributions of time, expertise, and facilities by CCMA members and staff added greatily to the success of this project.

\section{NOTICE}

This report was prepared as an account of work sponsored by an agency of the United States government. Neither the United States government nor any agency thereof, nor any of their employees, makes any warranty, express or implied, or assumes any legal liability or responsibility for the accuracy, completeness, or usefulness of any information, apparatus, product, or process disclosed, or represents that its use would not infringe privately owned rights. Reference herein to any specific commercial product, process, or service by trade name, tradmark, manufacturer, or otherwise does not necessarily constitute or imply its endorsement, recommendation, or favoring by the United States government or any agency thereof. The views and opinions of authors expressed herein do not necessarily state or reflect those of the United States government or any agency thereof. 
A. ENERGY UTILIZATION . . . . . . . . . . . . . . 1-1

B. PERFORMING AN "IN-HOUSE" ENERGY AUDIT . . . . . . . . . 1-5

A. ELECTRICAL POWER

Use in foundries . . . . . . . . . . . . 2-1

Electrical terminology . . . . . . . . . . . 2-1

Reading the bill . . . . . . . . . . . . 2-2

The Energy Charge . . . . . . . . . . . . 2-5

The Fuel-Adjustment Charge . . . . . . . . . . . 2-6

The Demand Charge . . . . . . . . . . . . 2-6

Power factor . . . . . . . . . . . . . 2-6

Power factor Improvement . . . . . . . . . . 2-7

Power demand controls . . . . . . . . . . . . 2-8

Demand shifting ................. 2- 2-8

off-peak melting . . . . . . . . . . . . . . 2-9

Maximization of melting capacity . . . . . . . . 2-13

Electric arc furnaces . . . . . . . . . . . . 2-14

Induction furnaces . . . . . . . . . . . . 2-17

Electric resistance heated reverberatory melting furnace - 2-19

Graphite rod holding furnace... . . . . . . . 2-20

Ladle Metallurgy . . . . . . . . . . . . 2-20 
A. Cont inued:

Plasma Fired Cupola . . . . . . . . . . . . 2-21

Plasma Assisted Cupola . . . . . . . . . . . 2-23

B. NATURAL GAS AND EQUIVALENT FOSSIL FUELS

Usage in foundries . . . . . . . . . . . . 2-24

Terminology and the bill ............... 2-25

In-plant metering ................. 2-26

obtalning a combustion analysis ........... 2-27

Temperature measurements . . . . . . . . . 2-30

Burner combustion efficiency ............ 2-31

Premix burner systems .. . . . . . . . . . 2-32

Nozzle mix burners . . . . . . . . . . . . 2-32

Furnace pressure controls . . . . . . . . . 2-35

Furnace efficiency . . . . . . . . . . . . 2-36

Furnace covers . . . . . . . . . . . . . 2-37

Crucible pot and reverberatory furnaces ........ 2-38

Upgrading gas fired furnaces . . . . . . . . . . 2-38

Heat treat furnaces . . . . . . . . . . . 2-39

Ladle heating . . . . . . . . . . . . . 2-41

Cokeless cupola . . . . . . . . . . . . . . 2-43

C. COKE AND SUPPLEMENTAL FUELS

Use in foundries............... 2-. 2-45

Foundry coke ..................... 2-46

Supplementary fuels . . . . . . . . . . . . 2-46

Storage .................... 2-. 247

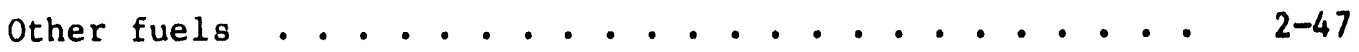

Cupola modifications... . . . . . . . . . 2-48 
D. WASTE HEAT RECOVERY SYSTEMS

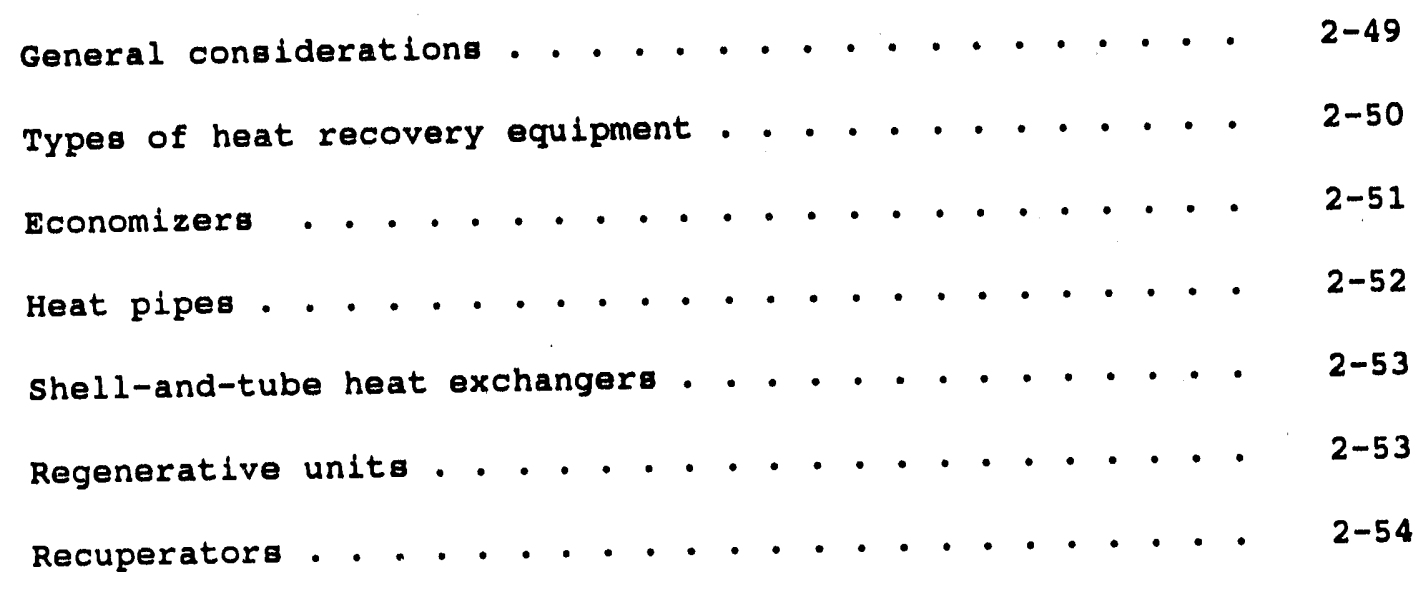

E. PROCESSES OF SECONDARY IMPORTANCE

cleaning and finishing . . . . . . . . . . . . . . . 2-56

Mold and core making . . . . . . . . . . . . . . . 2-57

Pouring and shakeout . . . . . . . . . . . . . . . . 2-57

Compressed air systems . . . . . . . . . . . . . . . 2-58

Dust and fume collection . . . . . . . . . . . . . . 2-60

Heating, ventilation and air conditioning . . . . . . . 2-60

Process water . . . . . . . . . . . . . . . . . 2-61

Plant lighting systems . . . . . . . . . . . . . . 2-62

F. LONG TERM PROCESS CHANGES

Charge preheating . . . . . . . . . . . . . . . . . 2-63

Co-generation . . . . . . . . . . . . . . . . . . 2-64

G. MANAGEMENT ACTIONS

Yield improvement programs . . . . . . . . . . . . . 2-66

Establish energy management program . . . . . . . . . . 2-69

Operating procedures . . . . . . . . . . . . . . . . $2-70$

H. MAJOR PROCESS CHANGES

Melting (gas versus electric) . . . . . . . . . . . . . 2-71 
H. Continued:

Melting (coke versus electric) . . . . . . . . 2-72

Cost comparison analysis................ 2-73

Ladle preheat (gas versus electric) . . . . . . . . 2-73

Insulating board linings................ 2-74

SECTION 3 - ANALYSIS OF ENERGY CONSUMPTION

A. ELECTRIC MELTING

General . . . . . . . . . . . . . . 3-2

Input data... . . . . . . . . . . . . . 3-2

Load profile development . . . . . . . . . . . . 3-4

off-peak melting . . . . . . . . . . . . . . 3-7

Demand shifting and demand control... . . . . . . 3-10

Demand control .. . . . . . . . . . . . . 3-14

Power factor correction .. . . . . . . . . . 3-15

Improved furnace design . . . . . . . . . . . 3-15

Summary - potential energy savings . . . . . . . . . 3-17

B. NATURAL GAS MELTING

General considerations............... 3-18

Gas furnace data input . . . . . . . . . . . . 3-19

Graphs, tables and charts ........ . . . . . 3-20

Sample calculations (crucible furnace)

Improving combustion efficiency . . . . . . . . 3..27

- Combustion air preheating ........... . 3-29

- Refractory materials ............... 3-30 
B. Continued:

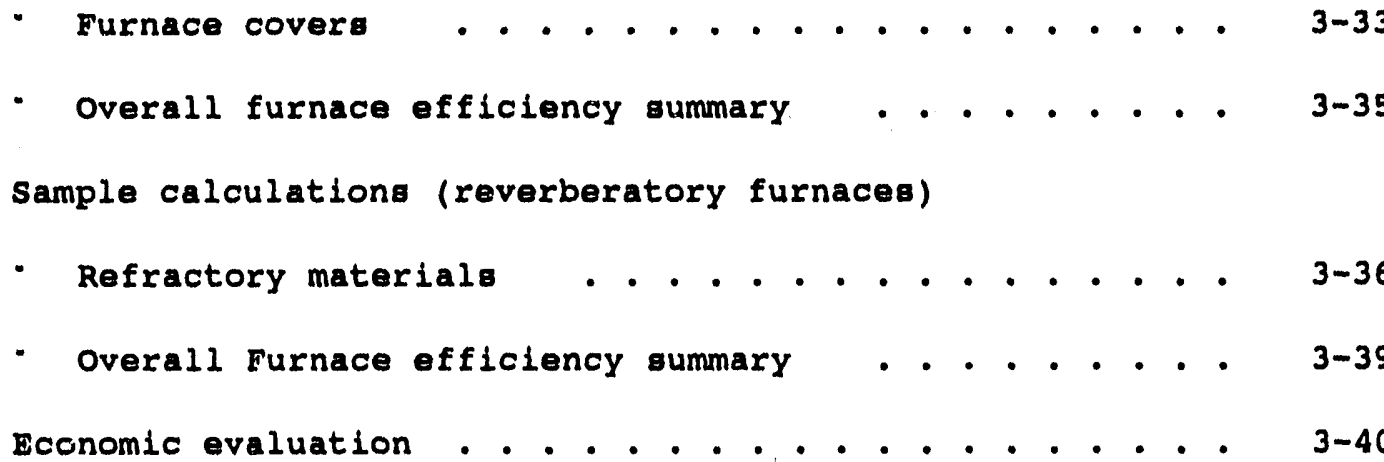

HEAT TREATING

General considerations............... 3-41

Heat treat data input ............... . 3-42

Tables, graphs, and charts.......... . . . . 3-43

sample calculations .. . . . . . . . . . . . 3-46

- Upgrading furnace linings . . . . . . . . . . 3-46

- Improving combustion efficiency . . . . . . . . 3-49

- Combustion air preheating ........... . 3-51

- Overall furnace efficiency ........... . 3-51

Economic evaluation ...... . . . . . . . . 3-52

LADLT HEATING

General ................... 3-53

Load operational data fact sheet... . . . . . . . 3-53

Graphs, tables, and charts.............. . 3-54

sample calculations . . . . . . . . . . . . 3-57

- Ladle covers ................. 3-57

- Combustion systems ............. 3-58

- Insulation .. . . . . . . . . . . . 3-59

Economic Evaluation ................ . . 3-61 
C. COKE FUEL MELTING (CUPOLA)

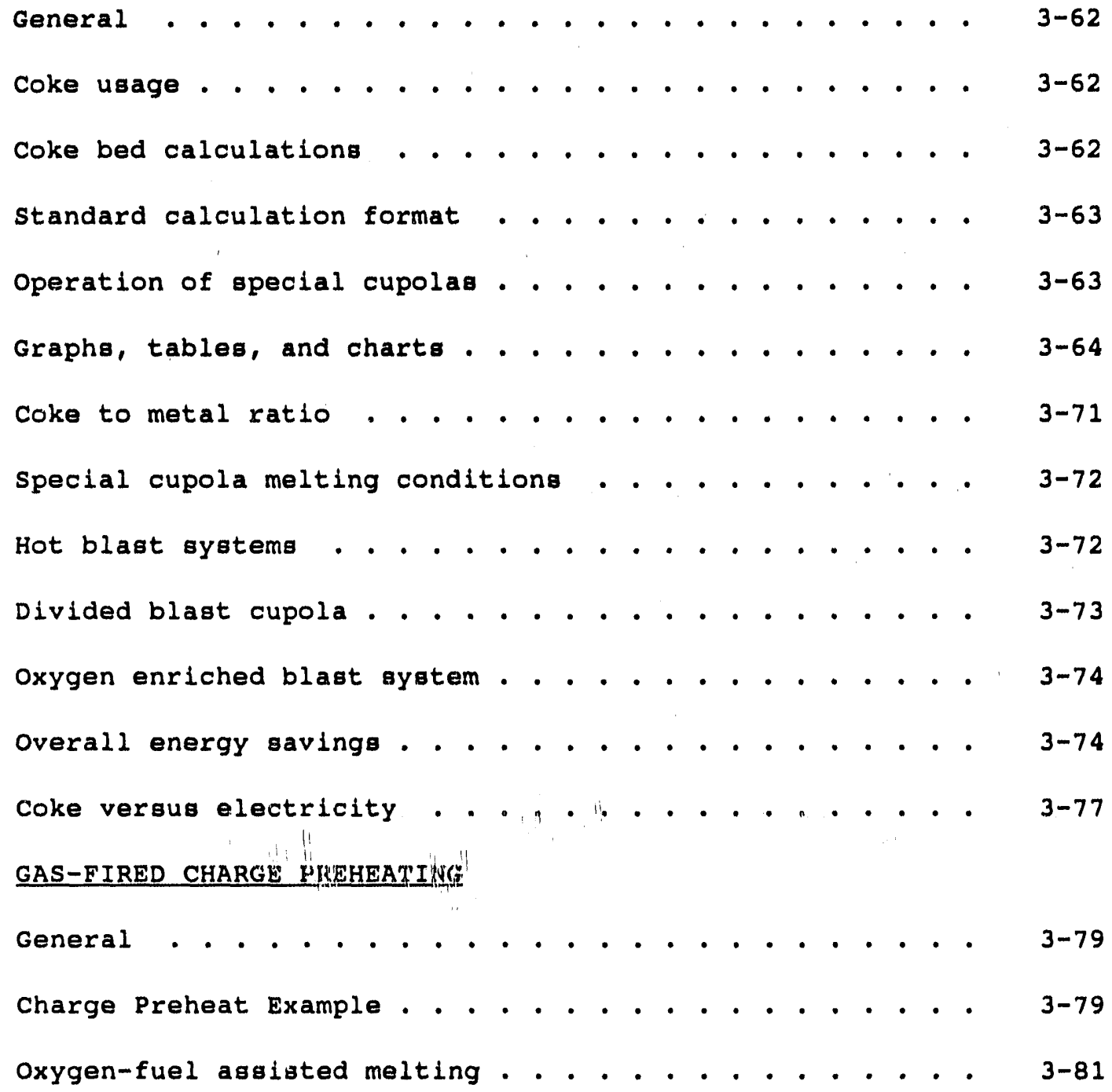

SECTION 4 - ENERGY AUDIT FORMS

A. ENERGY USE TABLES AND PRODUCTION STATISTICS . . . . . . 4-1

Electrical Power ugage... . . . . . . . . . . . 4-2

Annual Gas Consumption................ 4-3

Annual Coke Consumption ................ 4-4

Annual 011 Consumption............... 4-5 
A. Continued:

Annua1 Propane Consumption . . . . . . . . . . 4-6

Annual Production ............... . . 4-7

Plant Equipment Horsepower List . . . . . . . . . 4-8

Flow Rates of Gas Fired Equipment . . . . . . . . . 4-9

Present Energy-Efficlency Record . . . . . . . . 4-10

Potential Energy-Efficlency Record . . . . . . . . 4-11

B. OPERATIONAL DATA FACT SHEETS . . . . . . . . . 4 4-12

7-day Electrical Load Profile Form . . . . . . . . 4-13

48-hour Electric Load Profile Form . . . . . . . . 4-14

Electric Arc Furnace Data .. . . . . . . . . 4-15

Coreless Induction Furnace Data . . . . . . . . 4-16

Gas Melt Furnace Data .. . . . . . . . . 4-17

Heat Treat Furnace Data . . . . . . . . . . 4-18

Burn-Out Furnace Data .............. 4-19

Ladle Preheat Data. . . . . . . . . . . . 4-20

Cupola Furnace Data . . . . . . . . . . . . 4-21

Electric Heat Treat Furnace Data . . . . . . . . 4-22

Gas-Fired Scrap Reheat Data . . . . . . . . . 4-23 
SECTION 5 - ENERGY SAVINGS PROCEDURES CHECK LIST

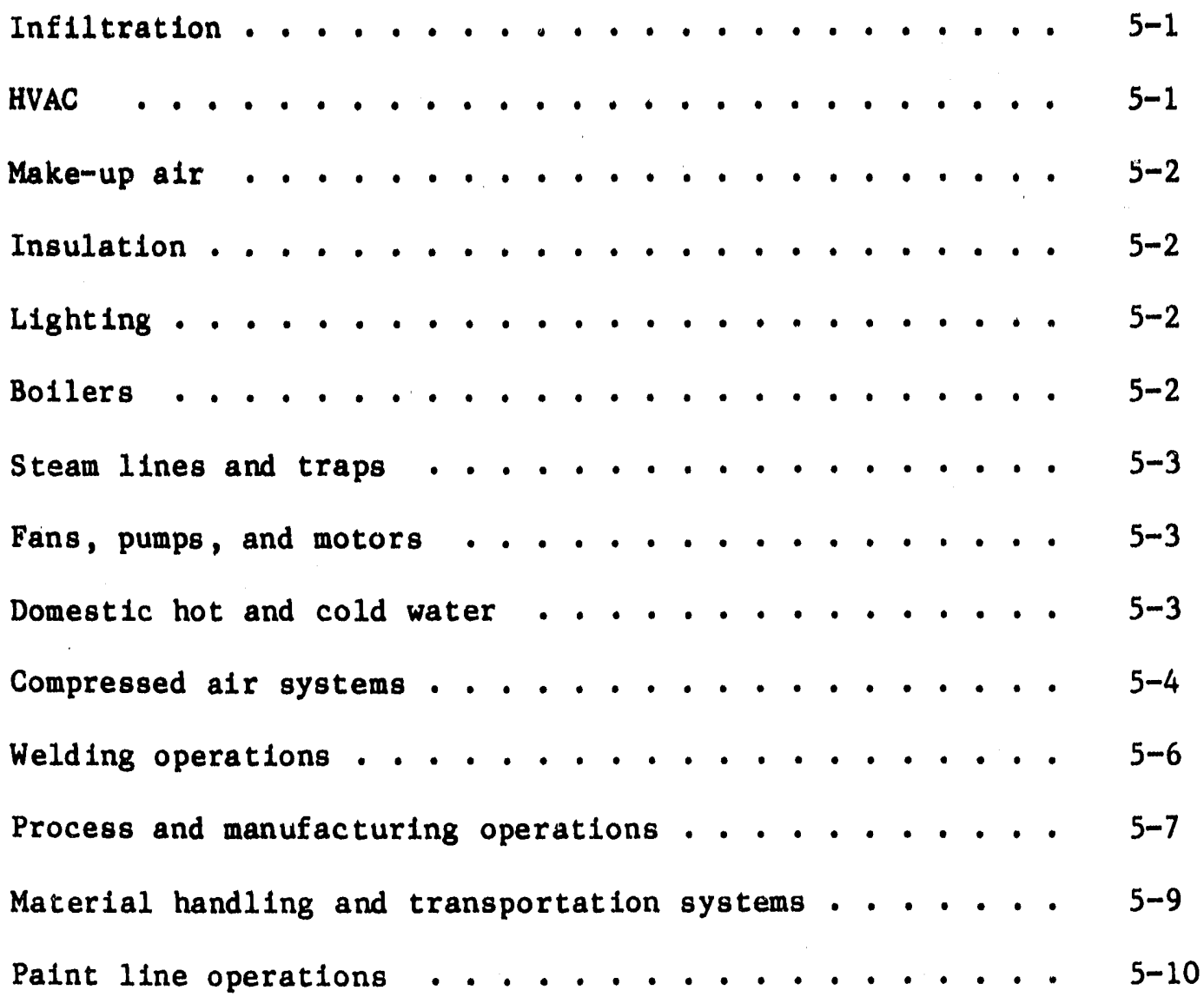

\section{SECTION 6 - EXAMPLE ENERGY ANALYSIS}

A. GENERAL DESCRIPTION . . . . . . . . . . . . . 6-1

B. ENERGY USE TABLES

Electrical power usage, Table 6-I . . . . . . . . 6-2

Annual gas consumption, Table 6-II . . . . . . . . 6-3

Annual coke consumption, Table C-III . . . . . . . 6-5

Plant equipment H.P. 11.st, Table 6-IV .......... 6-6

Flow rates of gas-fired equipment, Table 6-V . . . . . 6-9 
B. Continued:

Present energy-efficlency record table, Table 6-VI . . . 6-10 Energy-efficlency record table, Table 6-VII . . . . . 6-11

C. PRODUCTION STATISTICS

Annua1 production, Table 6-VIII . . . . . . . . 6-12

D. OPERATIONAL DATA FACT SHEETS

Electrical load profile, Figure 6-1 . . . . . . . 6-13

Heat treat furnace data, Table 6-IX .......... 6-14

Ladle preheat data, Table 6-X . . . . . . . . . 6-16

Cupola furnace data, Table 6-XI ........... 6-17

E. ENERGY CONSERVATION POTENTIAL

Methodology . . . . . . . . . . . . . 6-18

Electrical energy cost saving . . . . . . . . . 6-19

Damand controlling ................. 6-20

Kilowatt demand load profile industrial

Demand ccntrolling, Table 6-XII . . . . . . . . 6-21

Upgrading heat treat furnace ............ . 6-22

Upgrading ladle heaters . . . . . . . . . . . 6-23

Upgrading cupola furnaces . . . . . . . . . . . 6-24

F. ECONOMIC ANALYS IS

Electric energy .................. 6-25

G. SUMMARY OF ENERGY REDUCTION PROCEDURES

Summary of energy reduction . . . . . . . . . . 6-26

Profected energy-efficlency record .......... 6-27 
INTRODUCTION

There is no longer any need to stress the Importance of saving energy. Price increases and the realization that reserves of fossil fuels are finite and 1imited is an internationally recognized fact of modern 11 fe.

As a result, many governments, while searching for alternative energy sources and supporting new energy development programs, are taking direct action to conserve those resources that still remain. This workbook and the seminars that w111 be represented using this workbook are examples of this type of effort.

The foundry industry is a significant user of energy, and therefore, a natural candidate for efforts to save energy and improve efficlency by both governmental agencles and technical/trade associations. These efforts are designed to both imp:ove the national energy position and improve the industry's efficiency and profitability.

Increased energy cost and the reduced avallability of fossil fuels at certain times have provided the incentive to curb waste and to utilize purchased energy wisely. Energy costs now approach and sometimes exceed $10 \%$ of the sales dollar of many foundrles. Although energy use by foundries has gradually decreased on a per/ton basis in recent years, the foundry industry must continue to find ways to utilize energy more effictentiy.

\section{A. ENERGY UTILIZATION}

The average foundry consumes approximately 70 to 80 percent of its total energy input in three principal areas of operation:

- Melting operations

- Heat treating operations

- Ladle heating operations

Areas of secondary Importance for energy reduction measures are:

- Cleaning and finishing operations

- Mold and core making

- Pouring and shake-out 
- Sand reclaim system

- Dust and fume collection

- Compressed air systems

- Heating, ventilation and air conditioning systems

- Process cooling water systems

- Domestic hot water heating systems

Additional areas where energy conservation measures may be utilized:

- Building lighting systems

- Builúing weatherproofing

- System shut down during nonproduction periods

- Improvement in preventive maintenance programs

Long term process changes for significant energy reduction measures are:

- Scrap preheating

- Increasing yield

- Reduction in casting weight

- Reduction in holding furnace operations

- Preheating of castings

- Cogeneration systems

As stated above, approximately 70 to $80 \%$ of a foundry's energy input is consumed by melting, heat treat and ladle heating operations. Investment casting facilities and foundries in colder clinates, however, would reduce this percentage due to the relatively large amounts of energy consumed for large process air condtioning systems and make-up air ventilation systems. 
The following is a typical example of the energy mix and annual consumption rates in a steel foundry:

\begin{tabular}{|l|c|c|}
\hline \multicolumn{1}{|c|}{ Item } & Btu's per yr $\left(\times 10^{6}\right)$ & * overall energy \\
\hline Natural Gas & & \\
\hline Heat treat & 30,180 & 42 \\
Ladle heating & 16,490 & 23 \\
Core drying and misc. gas & $\frac{681}{47,351}$ & 1 \\
Subtotal & & \\
Electricity & 13,000 & 18 \\
Arc furnace (5 tons) & 1,000 & 1.5 \\
Induction furnace (250 $\mathrm{kW})$ & 750 & 1.0 \\
Lighting & 7,000 & 10 \\
Major motors & 3,000 & 3.5 \\
Misc. Electrical & 24,750 & 100 \\
\hline Subtotal & 72,101 & \\
Foundry total & & \\
\hline
\end{tabular}

NOTE: Above figures not applicable to nonferrous operations.

The above figures are purely hypothetical from the standpoint of yearly energy consumed by various processes; the overall energy utilization percentages are fairly representative of a steel foundry operation. The energy mix is approximately $66 \%$ gas and $34 \%$ electricity.

Based on the above observations this energy conservation workbook will address the three primary energy consuming processes, as previously mentioned, namely metal melting, heat treating and ladle preheating. An in-depth energy management analysis will be performed, by utilizing hypothetical mathematical models, to 111 ustrate the potential energy savings and energy cost reduction measures possible by modification of existing equipment aud/or changing basic process operations.

The principal areas for the "In depth" analysis will be as follows:

A. Gas Consuming Equipment

1. Heat treat furnaces:

(a) Installation of recuperators to preheat combustion air.

(b) Changing of burner system from atmospheric type to sealed - pressure regulated burners.

(c) Upgrading of heat treat furnaces to eliminate cracks and openings. 
(d) Change conventional fire brick to ceramic fiber 1iners.

2. Crucible or reverberatory furnaces:

(a) Installation of recuperators to preheat combustion air.

(b) Change burner system.

(c) Replace castable refractory with vacuum - formed ceramic fiber.

(d) Provide charge access covers while furnace is in a holding mode.

(e) Install electric melt furnaces.

3. Ladle heating:

(a) Change burner from atmospheric to gas and compressed air with regulators.

(b) Install insulated covers

(c) Add insulation

(d) Change to electric ladle heating

B. Coke Consuming Equipment (Cupola)

1. Twin blast lined cupola

2. Hot blast lined cupola with recuperation

3. Hot blast water cooled cupola with recuperation and gas afterburners

4. Oxygen enriched cupolas

C. Electrical Consuming Equipment

1. Electric Arc Melting Furnace

(a) off-peak melting

(b) Controlling demand

(c) Maximizing heat transfer

(d) Load management and optimization

(e) Installing water cooled blocks 
2. Induction Furnace Melting (Coreless)

\author{
(a) off-peak melting \\ (b) Improve operational methods \\ (c) Improved furnace design \\ (d) Oxygen-fuel assisted melting \\ (e) Water cooling heat recovery \\ (f) Maximization of melting capacity
}

3. Induction Furnace Melting (Channel)

(a) Off-peak melting
(b) Improve furnace design
(c) Water cooling heat recovery

Energy conservation associated with other foundry processes (1.e., those that collectively represent approximately $20 \%$ of total energy input) will be discussed briefly, however, no attempt will be made to quantify possible energy savings.

\title{
PERFORMING AN "IN-HOUSE" ENERGY AUDIT
}

An efficient energy management program can only be implemented successfully if energy consumption habits of various foundry equipment is identifled and recorded in a logical and workable format.

The result of active energy management is improved energy utilization; this invariably pays off in dollars, as well as making a major contribution to the national drive towards energy conservation.

To effect this result management should implement the following procedures:

1. Understand the plant's energy services and organize for dayto-day control.

2. Cost the energy services to determine incentives for potential profit.

3. Apply the same basic business principles to energy services that are used for other materials and supplies.

4. Encourage a long range energy plan that fits future plans of the foundry.

5. Initiate regular performance reports on energy usage. 
Before the above work assignments can be put into effect, a comprehensive plant energy audit must be conducted. The following is a step by step procedure for an "In-house" audit.

1. Analyze 8as, electricity and miscellaneous fuel bills for the past 12 months and convert all energy information into Btu's; use the following converion figures to accomplish this:

- $1 \mathrm{kWh}=3,412 \mathrm{Btu}$ 's

- 1 MCF natural gas $=1,000,000$ Btu's

- 1 pound coke - 12,500 Btu's

- 1 gallon of propane $=91,600$ Btu's

While tabulating annual consumption of energy sources into Btu's and dollars, an attempt should be made to determine which departments use how many Btu's of which fuel type (Installation of in-house metering is essential for accurate data).

2. Analyze and record production schedules for the same time frame used for energy consumption. Total number of units in pounds produced by each department and the entire foundry should be recorded, also on a month to month basis. Make sure all information is recorded in units or weight and not a combination of both.

3. Physically inspect all equipment and identify systems or processes which are wasting energy and offer the best cost effective energy program. To determine equipment eff1clencles, the following data should be recorded:

(a) Total running time of equipment per day

(b) Hourly energy consumption converted to Btu's

(c) Operating temperatures

(d) Flue and stack temperatures

(e) Flue and stack airflow rates

(f) Combustion data: i.e., $\mathrm{CO}_{2}$ content of flue gas

(g) Type and model number of gas burners

(h) Anc1llary motor horsepowers

(1) Material through-put in pounds

(j) Electrical demand profile and power factors 
4. Ut1lization of data gathered under 1 tems 1, 2, and 3 will be sufficient to calculate:

- Avallable heat to do useful work

- Efficlency of equipment

- Avallable heat for reclamation

- Electric power utilization and efficlency

- Percent energy savings

Section 3 will show examples of how to construct an energy flow diagram by utilization of mathematical models. Also, Section 3 will 11lustrate the necessary procedures required to calculate potential energy savings .

Construction of energy flow dlagrams for varloug equipment processes will identify which areas of fer the greatest energy saving potential. The final step is to make an economic evaluation in order to calculate the return on investment for capital improvements. Return on investment (ROI) will require the following input information.

- First Cost (Capital Expenditure)

- Annual Operating Costs

- Annua 1 Fuel Savings

- Profected Fuel Price

- Estimated Life

A simple method for economic analysis is to calculate the payback perlod; this method utilizes the above basic data and will be used in this study. 


\section{A. ELECTRICAL POWER}

\section{USE IN FOUNDRIES}

As stated previously the typical usage of electrical energy in a steel foundry amounts to approximately 348 of the total energy used. The percentage could be much higher in foundries engaged in around the clock electric melting and minimal heat treat operations. Nonferrous foundries, on the other hand, will generally utilize less than 348 of electrical energy due to heavy gas melting.

Electrical energy is used in the following foundry operations:

- Melting metal

- Refining metal

- Holding melted metal

- Transporting meltod metal

- Mixing and transporting sand

- I'ransporting cores and molds

- Cleaning and finishing (air compressors)

- Environmental control

- Miscellaneous equipment

- Lighting

- Heat treating

\section{ELECTRICAL TERMINOLOGY}

In this section reference will be made to various electrical units; to enable an understanding of each unit, the following identification is provided:

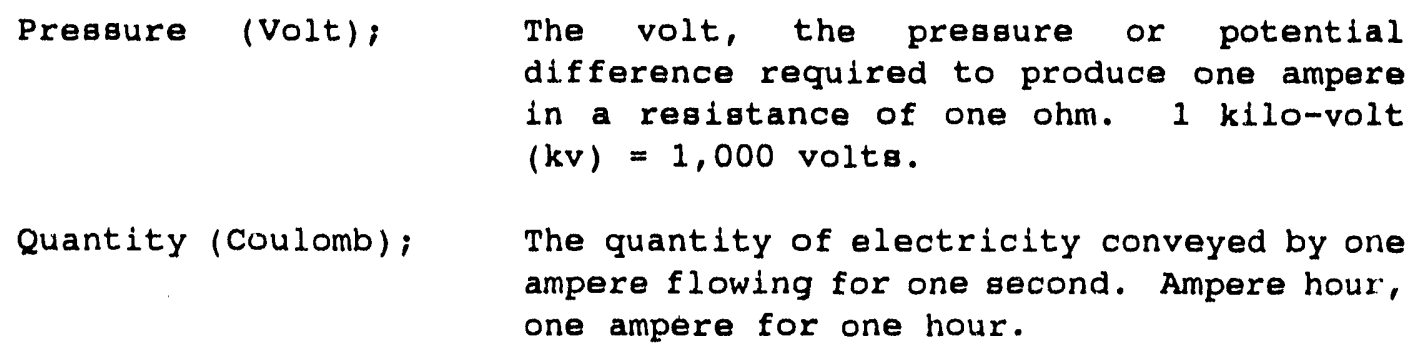


Power (Watt);

Energy (Joule);

Capacitance (Farad);

Current (Ampere);

Volt - Ampere;
The watt is the power generated by a steady current of one ampere at a pressure of one volt. The kllowatt $(\mathrm{kw})=1,000$ watts. One hor sepower $=746$ watts.

The foule is the energy conveyed by one watt during one secnnd, the kllowatt hour ( $k w h$ ) is one kilowatt flowing for one hour.

The farad is the electrostatic capacitance which will hold a charge at a pressure of one volt.

The ampere, the rate of flow of a unvarying electric current.

The product of the rated load amperes and the rated range of regulation in kilovolts (kva).

READING THE BILL

The cost of purchasing electrical power from the utility companies is derived from four major factors; they are, energy charge, fueladjustment charge, demand charge, and low power factor penalty.

Other incldental items which affect the power charges are, character of service, service voltage, and equipment charges - these are fixed charges.

\section{ELECTRIC BILL TERMINOLOGY}

Example of a Typical Bill

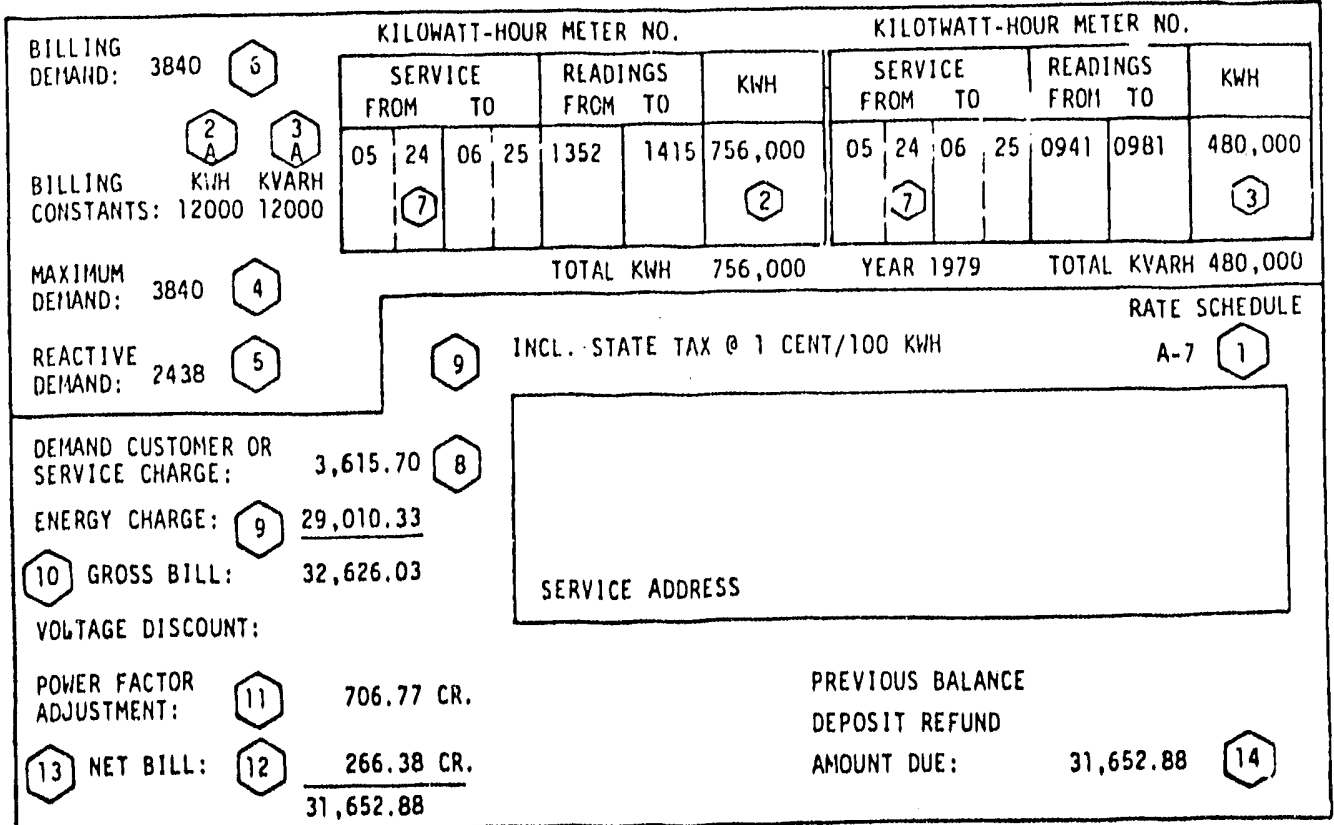




\section{EXPLANATION OF EXAMPLE ELECTRIC BIIL}

1. The utility rate schedule A-7 is the key to analyzing the electric bill. It is normally included as part of tho contract.

2. The energy used expreseed in kilowatt-hours (KWH) is determined by the difference of two monthly meter readings times the billing constant $2 A$.

The billing constants $2 A$ and $3 A$ are also described as "Meter Multipliers". They are determined by the product of the current and potential transformer ratiog installed at the particular location.

3. The reactive power used, sometimes called "wattless powtr", expressed reactive kilowatt ampere hourg (KVARH) is determinea from a separate reactive meter similar to the KWH meter 2 above.

This power is required to magnetize the steel cores of motors and transformers. It is not registered on the KWH meter.

4. The maximum demand in kilowatts for the current month is read from a separate register on the KWH meter. The value is the largest quantity of kilowatts consumed during a time interval prescribed in the contract. Example - 30 minuter.

5. The reactive demand in KVAR is calculated from the formula KVAR - KW (KVARH/KWH) .

6. The billing demand is the average of the maximum demand for the past 11 months and the current month's demand. The minimum is half of the past 11 -month value.

7. Date and time span of the current bililing. 
8. The service charge, as specified in the rate schedule, is based on the billing demand 1 tem 6 and the service charge, is also used as the minimum billing if the energy usage falls to a low value.

9. The electrical energy charge is based on the k1lowatt hours used as shown in item 2 . Certain adjustments are made to the energy charge determined from the meter readings as follows:

a) Energy cost adjustment known as "ECAC" varies with the change in fuel cost to the utility.

b) Fuel balance factor usually is a credit.

c) Load management factor.

d) State tax as indicated on the monthly bill.

10. The gross bill is the sumation of 1 tems 8 and 9 .

11. The voltage discount is avallable for services that are metered on the high voltage or primary side of the power company transformer. This discount is made to compensate for the utility transformer losses which are now included in 1 tem 2 .

12. The power factor adjustment may be a penalty or a discount depending on the amount of reactive power, item 3 , required by a plant. Power factor is defined as the ratio of the $\mathrm{kW}$ to KVA, sometimes stated as the ratio of "real power to the apparent power", this value is not read directly from the ut1lity meters but must be calculated. A simpler method, using a hand calculator, is to solve as a right angle triangle where power factor $(\mathrm{PF})=\mathrm{KW} / \mathrm{KVA}=\mathrm{KWH} / \mathrm{RKVAH}$$$
\mathrm{RKVAH}=(\mathrm{KWH})^{2}+(\mathrm{RKVAH})^{2}
$$$$
\text { This month's PF }=756,000 /(756,000)^{2}+(480,000)^{2}=0.849
$$$$
\% \mathrm{PF}=100(0.849)=85.9 \% \text { Power Factor }
$$ 
On this rate schedule a power factor over 70.7 \& provides a oredit, below a penalty, however, other utilities may use a different break even point - 858 is used by many.

13. City tax where applicable.

14. Net bill is the summation of all of the above chargea, adjustmenta, and credita.

\section{THE ENERGY CHARGE}

Energy charge is based on the number of kilowatt hours (kWh) used during the billing cycle. The total kilowact hours are multiplied by the energy charge for total energy billing. The energy charges can vary with the type of service, voltage, and energy consumption. Example - energy rate schedules are as follows:

Example 1. General service schedule which lo applied to electrical load demand of up to 8,000 (kWh) kilowatt hourg per month. Thus a nondemand charge schedule, the cost of energy and demand are one charge.

Example 2. Rate schedule A-12 lo applied to electrical load demand of 30 to 1,000 kilowatt $(\mathrm{kW})$ of demand per month. This schedule has an energy charge, fuel-adjustment charge, demand charge, and low power factor penalty.

Example 3. Rate schedule A-22 is applied to electrical load demands of 1,000 to 4,000 kilowatt $(\mathrm{kW}$ ) of demand per month. This schedule has an energy charge, fuel-adjustment charge, demand charge, and low power factor penalty. This rate schedule has a "time of day" billing rate for energy and demand for both eummer and winter. The summertime hour periods are from 1 May to 30 september; the energy and demand charges change between the following hours:

- Peak hours - $12: 30 \mathrm{pm}$ to $6: 30 \mathrm{pm}=6$ hours

- Partial peak hours $-8: 30$ am to $12 ; 30 \mathrm{pm}=4$ hours

- Partial peak hours - 6:30 pm to 10:30 pm = 4 hours

- Off peak hours - 10:30 pm to $8: 30 \mathrm{am}=10$ hours

The wintertime hour periods are from 1 october to 30 April; the energy and demand charges change between the following hours:

- On peak hours $-4: 30 \mathrm{pm}$ to $8: 30 \mathrm{pm}=4$ hours

- Partial peak hours $-8: 30$ am to $4: 30 \mathrm{pm}=8$ hours

- Partial peak hours $-8: 30$ pin to $10: 30 \mathrm{pm}=2$ hours 
Example 4. Rate schedule $A-23$ 1s applied to eleotrioal load demanda of 4,000 and above kilowatts (kW) of demand per month. All other oharges and "time of day" billing hours and periode are the same ar rate schedule A-22. Additional rates are avallable for the purchase of supply voltage of 4,500 or 12,000 volta, this schedule provides for a high voltage discount of the total energy and demand charges.

\section{THE FUEL-ADJUSTMENT CHARGE}

This charge le tied directly to the energy charge and can only be reduced by a reduotion in overall enexgy usage. The fuel-adjustment change permits the utility companies to adjust the total oost for producing energy due to increased fuel costs, without making a request for a rate increase.

\section{THE DEMAND CHARGE}

This charge compensates the utility company for the capital invegtment required to serve peak loada, even if that peak load is only used for a few hours per week or month. The demand is measured in kilowatts ( $k W$ ) or kilovolt amperes (KVA); these unita are directly related to the amount of energy consumed in a given time interval of the bililing perlod. The demand perlods vary with the type of energy demand; the high fluctuating demand has a short demand perlod which can be as short as five minutes, but generally demand perlods are of 15 or 30 minutes. The perlod with the highest demand is the one used for bililing demand charges. For instance, on a 15-minute demand perlod with a 70 kllowatt demand, and then adding a further $70 \mathrm{kllowat}$ demand for $15 \mathrm{minutes}$ and then dropping back to 70 kilowatts for the rest of the billing period, the billing demand then is 140 kllowatts for that month. This represents the incerval of maximum energy demand from the utility system for that month. Demand charges can be a aignificant portion of the total electrical bill; in some cases, demand charges can amount to as much as 80 percent of the bill. The demand charge can be reduced by smoothing out the peaks in energy demand by rescheduling of work or through a demand control program to shed loads when a demand limit is approached. This concept is particularly important for foundries using electric melting procerses.

\section{POWER FACTOR}

Power factor, in aimple terms, is the ratio of actual power uged in a circuit, expressed in watts or kilowatts, to the power which is apparently being drawn from the line, expressed in volt-amperes or kilovolt amperes. Mathematically, power factor is expressed as

$$
\mathrm{PF}=\frac{\mathrm{KW}}{\mathrm{KVA}} \text { or } \mathrm{KVA} \times \mathrm{PF}=\mathrm{KW}
$$


Power factor can also be defined as the mathematical factor by which the apparent power is multiplied in order to obtain active power. For example: Assume a load on a 480 volt 3-phase system: The ammeter Indicates $200 \mathrm{amps}$ and the watt-meter reads $120 \mathrm{~kW}$ - What is the power factor of the load?

The apparent power for a 3 phase circult is given by the expression;

$$
\begin{aligned}
& \text { KVA }=\frac{E \times I \times \sqrt{3}}{1000} \\
&=\frac{480 \text { volts } \times 20 \mathrm{amps} \times 1.73}{1000}=290.6 \mathrm{KVA} \\
& \text { Therefore: } \quad \mathrm{PF}=\frac{\mathrm{KW}}{\mathrm{KVA}} \text { or } \frac{120}{290.6}=41.2 \%
\end{aligned}
$$

From the above example it is apparent that by decreasing the power drawn from the 11ne (kVA) the power factor can be increased.

\section{POWER FACTOR IMPROVEMENT}

Preventive measures involve selecting high-power-factor equipment. Only high-power-factor ballasts should be used for fluorescent and highintensity-discharge (HID) 1ighting. Power factor of so-called normalpower factor ballasts is notorlously low, on the order of 40 to 55 percent.

When induction motors are being selected, the manufacturer's motor data should be Investigated to determine the motor power factor at full load. In the past few years, some motor manufacturers have introduced premium lines of high-efficlency, high-power-factor motors. In some casest; the savings on power factor alone can justify the premium prices charefin for such motors. Motors should also be sized to operate as closety as possible to full load, because power factor of an induction motor gluffer severely at light loads. Power factor decreases because the inductive component of current that provides the magnetizing force, necessary for motor operation, remain virtually constant from no load to full loait, but the in-phase current component that actually delivers work varles alliost directly with motor loading.

Corrective measures for poor power factor involve cancelling the lagging curtent component with current that leads the applied voltage. This canccliation can be done with power-factor-improvement capacitors, or by ustag synchronous motors. Capacitors have the effect of absorbing reactive culrent on a one-to-one basis, because almost all of the current flowing through a capacttor leads the applied voltage by $90 \mathrm{deg}$. A capacitor rated at $100 \mathrm{kllovolt-amperes} \mathrm{capacitive} \mathrm{(kvac)} \mathrm{will,} \mathrm{therefore}$ cancel 100 kilovolt-amperes reactive (kvar). 
Synchronous motors provide an effective method of improving power factor because they can be operated at leading power factor. Moreover, power factor of a synchronous motor can be varied by varying the D.C. excitation applied to the motor. To be effective in improving power factor, remember, a synchronous motor cannot be applied to intermittent loads, because overall plant power factor will decrease when the motor is not in service.

A synchronous motor can be used in lieu of an induction motor, with a resulting improvement in power factor. In this example, using a synchronous motor to serve a load with actual power requirements of 1,000 $\mathrm{kW}$, Improves power factor on the load center from 80 percent to 89 percent. This improvement at the load center contributes to an improvement in overall plant power factor, thereby reducing the power factor penalty on the plant electric bil1. The burden on the load center, plant distribution system, and entire electric-utility system ts $400 \mathrm{kVA}$ less than $1 f$ an induction motor with a power factor of 85 percent were used. Power factor can be improved still more by operating the synchronous motor at leading power factor.

\section{POWER DEMAND CONTROLS}

The power demand controller automatically regulates or 11mits operation in order to prevent set maximum demands from being exceeded. The role of such a power demand controller has been widely recognized, the "time of day" bllling rates will make it far more necessary in the future. The type of controller best sulted for a foundry operation is that which w111 predetermine the demand IImit and the demand interval.

The overall usage of power is constantly monitored from the power company meter, the power usage of all the controlled loads is also monitored. By having this information the controller can calculate when an overrun of the desired demand 11mit will occur. The controller will delay any shed action to allow time for loads to shed normally. When $1 t$ is determined that it will be necessary to shed one or more loads, to keep from exceeding the demand, the controller at the last possible moment will shed the necessary loads. This means that shedding will occur only once during a demand interval and maximum use of avallable power will be realized.

\section{DEMAND SHIFTING}

Due to the lack of avallability and the increased cost of natural gas and petroleum products, Industry has come to rely on electrical power as a major source of energy. The use of electrical energy has increased at a greater rate than was anticlpated and therefore a critical shortage has also bcen created in some areas. This is particularly true during the normal working day hours. Over the past few years this condition has caused situations known as "brown-outs", which is controlled curtailment of power. 
Even with power componies doing their best to cope with the problem by bullding new generating stations, installing additional equipment in existing facilities, and operating all equipment at maximum capacity, they still have not been able, in some cases, to keep up with the rapid growth in the demand for electrical energy.

The demand for electrical energy is not constant, but occurs in peaks and valleys. Power companies are obligated to have enough equipment available to meet a customer's peak demand, even though this equipment is only used during tine peak periods and is not in use during most of the working day. In order to finance the equipment necessary to provide this peak demand service for industrial users, the power demand charge was created. In some localities this high demand rate is the rate which is paid for the next year, even if $1 t$ is never reached again, and the price pald for power demand can be very high.

With peaks and valleys in electrical demand, caused by electrical melting during the normal work day, maximum demand peaks should be controlled by sequencing the furnace's operation and maximum power input to each furnace. By applying this proceciure, the revised operation would level out the peak demands and produce a flat demand profile during normal day time melting. With this melting operation the "Load Factor" would be improved, thus preventing high maximum demand peaks, which are developed through all furnace's operating on full power at the same time. (See Figures 2-1 and 2-2 for comparison.)

\section{OFF-PEAK MELTING}

With the revised billing methods of "time of day" rates being adopted by the electrical utility companies, any energy user of 1,000 kflowatts ( $\mathrm{kW}$ ) or over of demand, each month, will be billed on the "time of day" billing rate schedule. It will be noted from the schedule that demand and energy charges are high during normal working hours, with no demand charge during the night hours and very low energy charges. If the metal melting operation was moved to a night operation, maximum savings could be made on energy costs with no demand cost charge. The amount of night melting will depend on the total melting and holding capacity available.

If the melting and holding capacity is limited, it: may require molding and pouring to be carried out at night together with melting to take full advantage of the "off-peak" electrical rates.

For graphic illustration of off-peak melting operations see Figure 2-3. For load profile for off-peak melting see Figure 2-4.

CAUTIONARY NOTE - It may be difficult to obtain adequate supervisory personnel for night shift operations resulting in quality and productivity problems. 


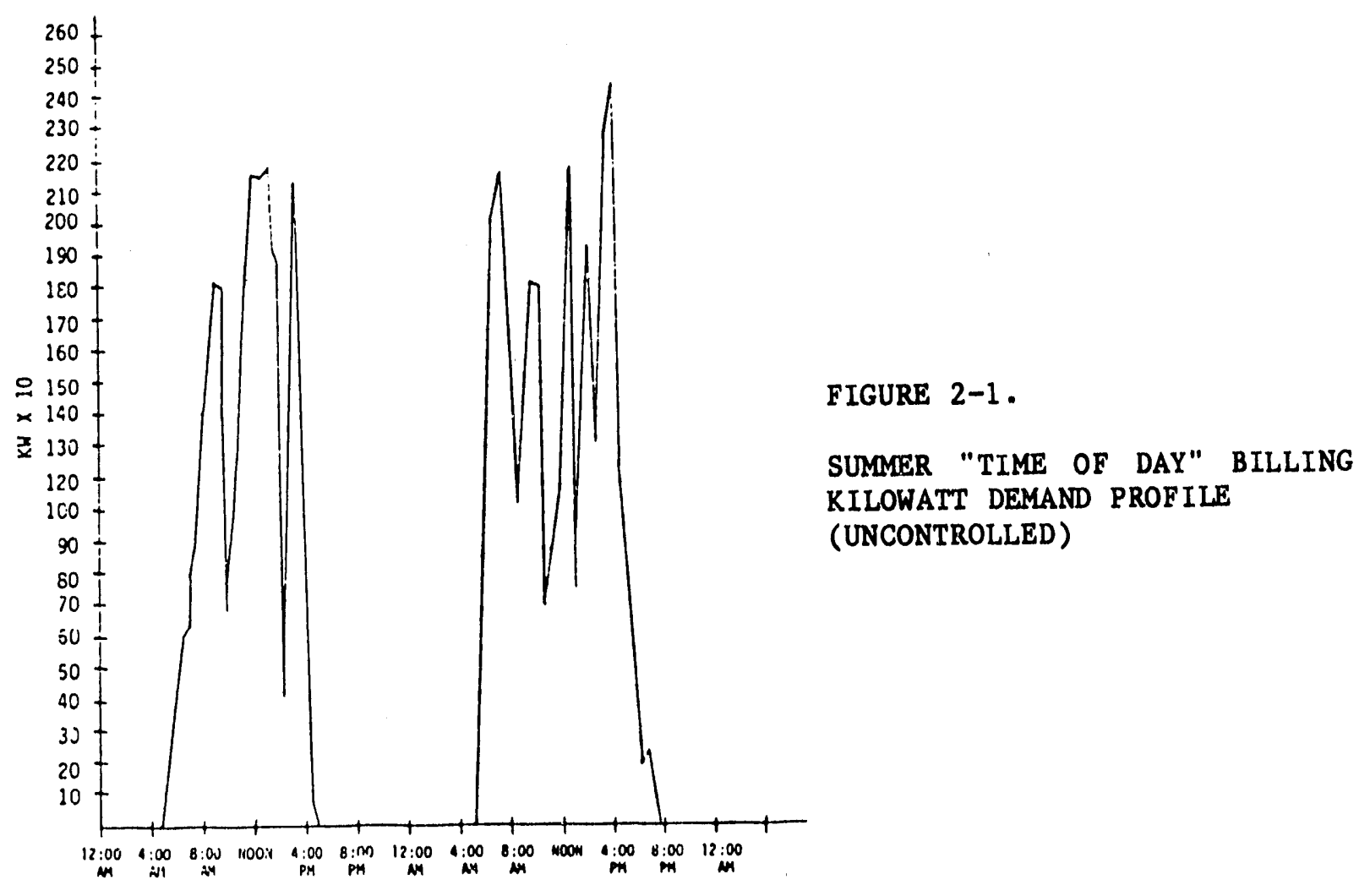

FIGURE 2-2.

SUMMER "TIME OF DAY" BILLING

KILOWATT DEMAND PROFILE (CONTROLLED)

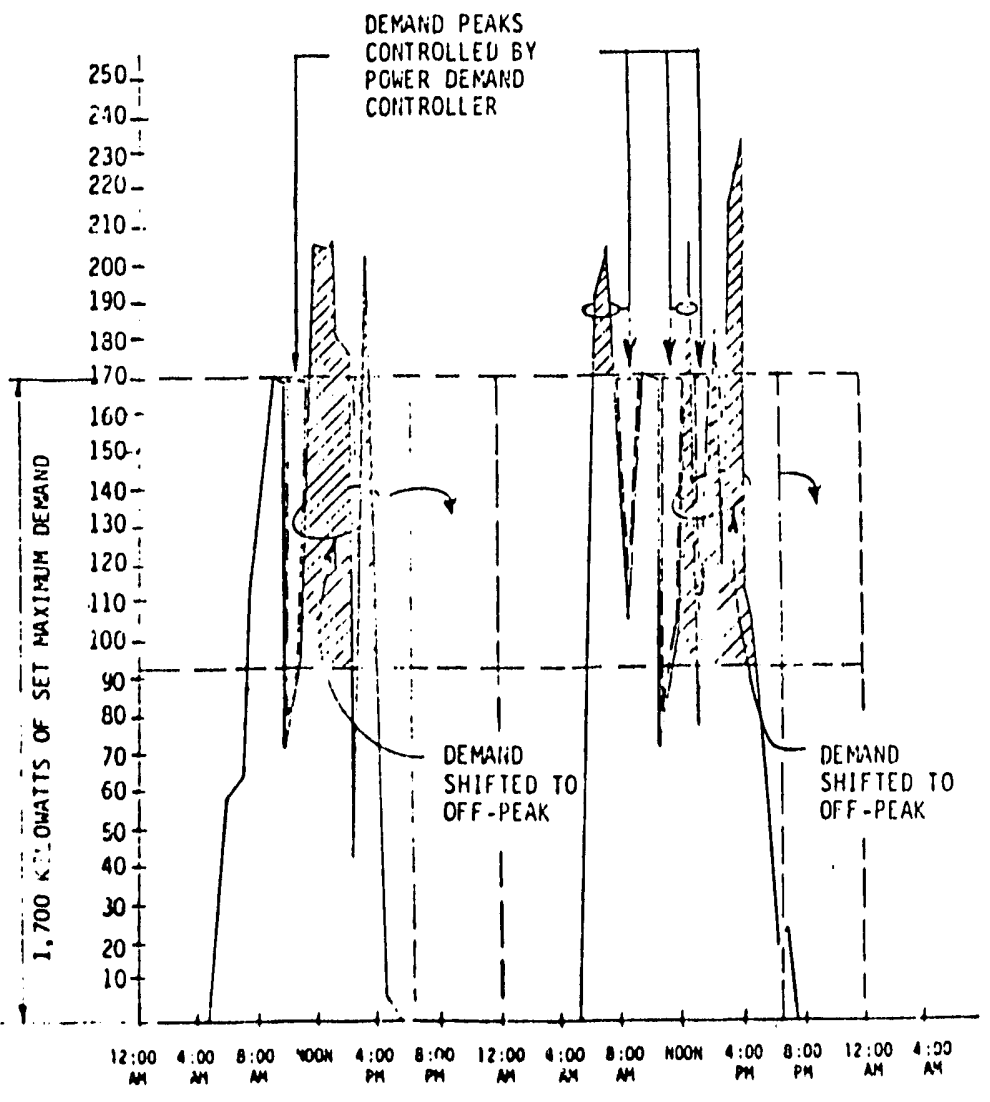




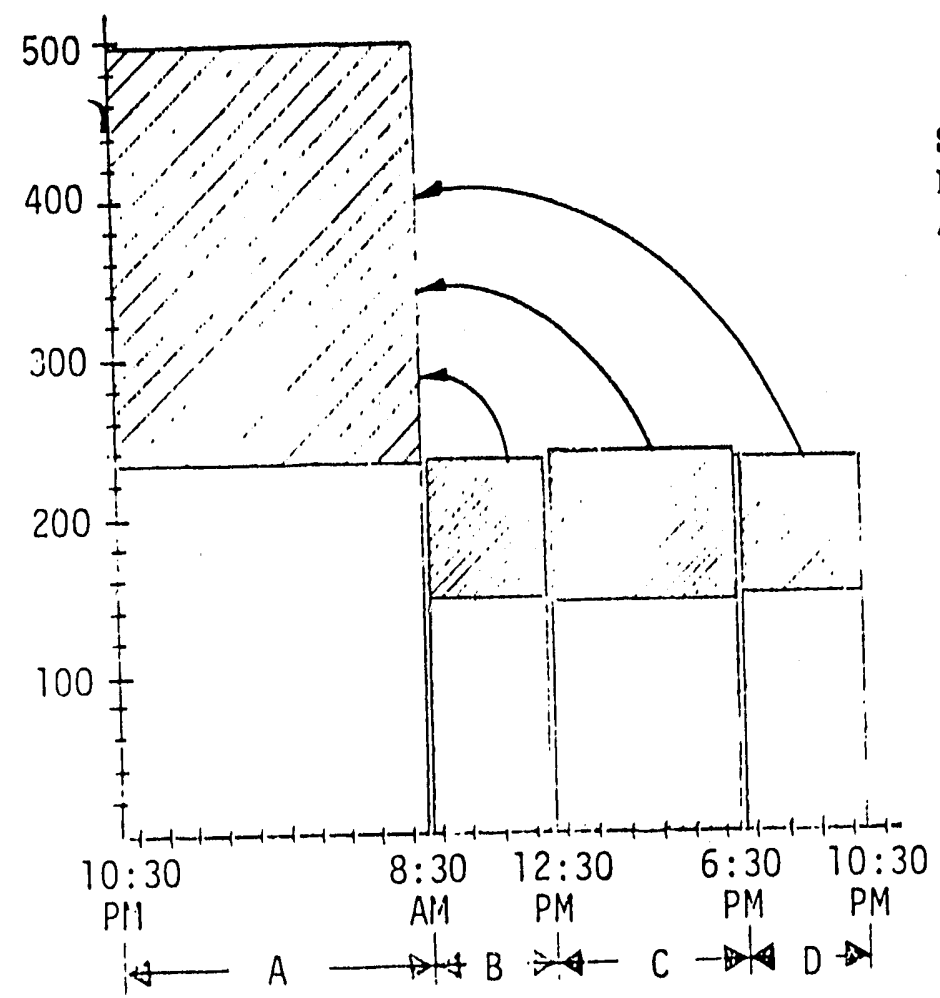

KILOWATT DEMAND BY "TIME OF DAY" BILLING

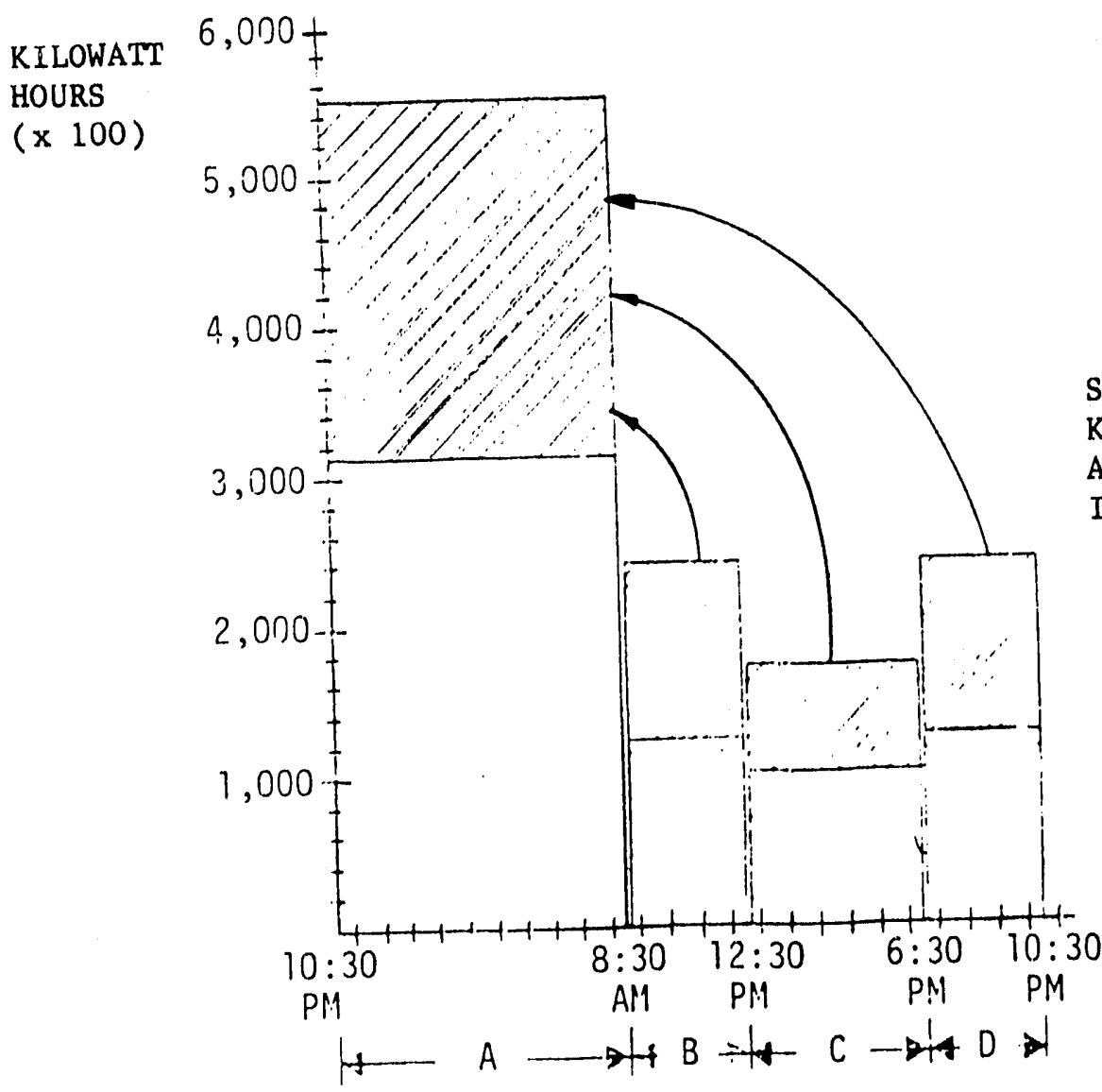

KILOWATT ENERGY USAGE BY "TIME OF DAY" BILLING

FIGURE 2-3 GRAPHIC ILLUSTRATION OF "OFF-PEAK" MELTING
SHADED AREA - REDUCTION IN KILOWATT DEMAND DURING ON-PEAK AND PARTIAL PEAK HOURS, WITH INCREASE IN OFF-PEAK PERIOD.
A OFF-PEAK HOURS
B PARTIAL PEAK HOURS
C N-PEAK HOURS
D PARTIAL PEAK HOURS

SHADED AREA - REDUCTION IN KILOWATT HOURS DURING ON-PEAK AND PARTIAL PEAK HOURS, WITH INCREASE IN OFF-PEAK PERIOD.
A OFF-PEAK HOURS
B PARTIAL PEAK HOURS
C ON-PEAK HOURS
D PARTIAL PEAK HOURS 


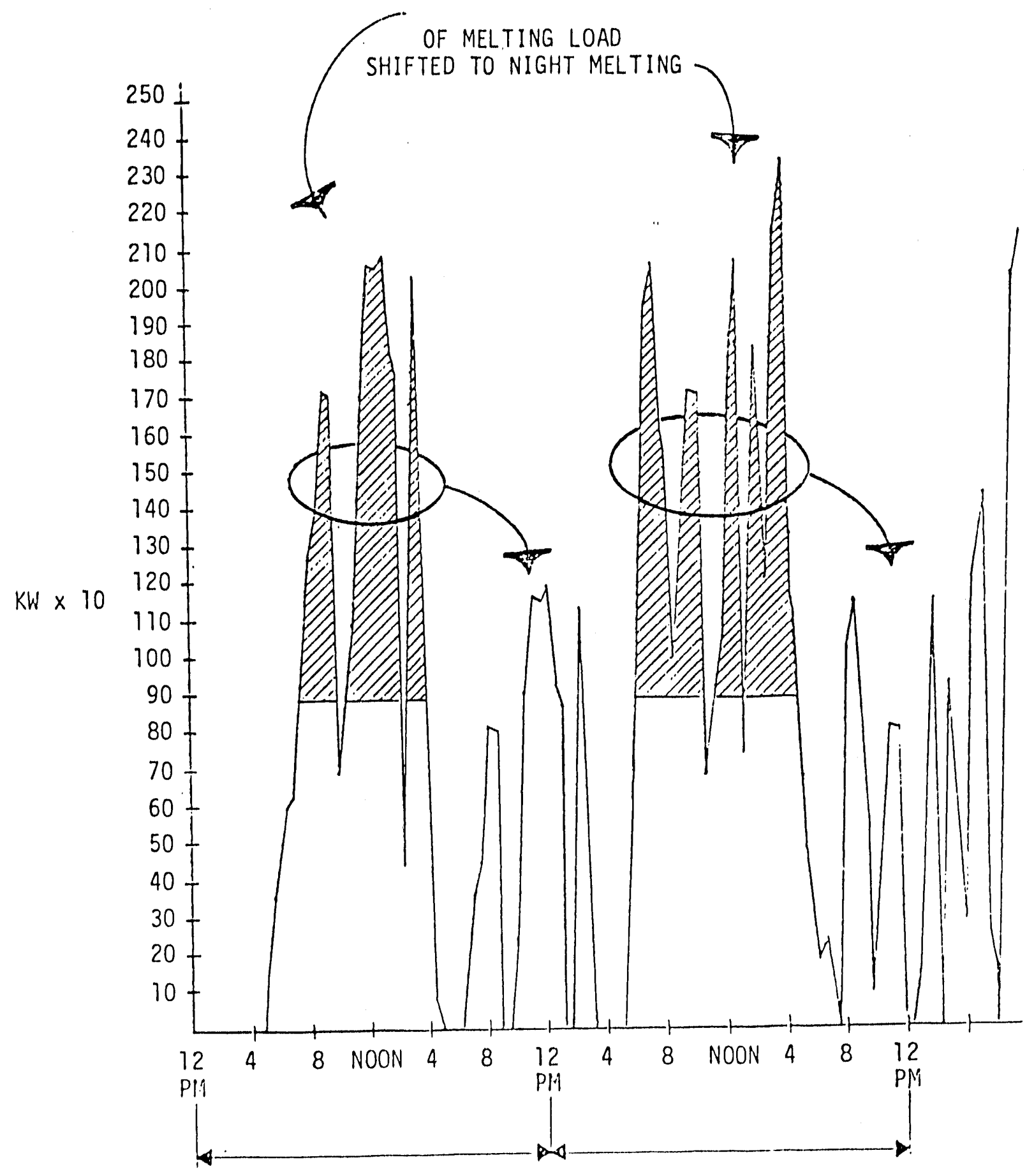

FIGURE 2-4 LOAD PROFILE - "OFF-PEAK" MELTING 
In this and other sections of this study references and recommendations have been or will be presented for electrical energy conservation in the melting of metal. As previouly stated, approximately 348 of the total energy used in a typical oteel foundry is electrical. of the 348 approximately 208 is uged for melting or holding melted metal. The total kllowatts used for melting a ton of metal can only be reduced with improved furnace efficiency and operation, which will reduce the melt rate (tons/hour) and reduce energy consumption (kllowatt hours/ton). Areas where maximizing the melting capacity can save substantial energy are:

- Load factor should operate at high percent power utilization. The measure of the efficiency of utilization of electrical energy, taken on a monthly basis, is determined as the ratio of the average consumption in the month to the peak demand in that month.

- Electrical power costa per ton of metal melted will increase when "holding" metal for any length of time due to decreased power utilization. This condition is due to the thermal losses becoming proportionally larger when the furnace is in the idling mode, thus a melting operation should utilize full furnace power whenever possible and restrict holding time, thereby maximizing energy-saving potential.

- During slagging and charging of induction furnaces, it is necessary to open the furnace cover or lid to accomplish the intended actions. When the lid is open, thermal losses occur due to radiation from both the lid refractory and from the molten iron. The longer the "lidopen" time, the greater the loss of energy from the furnace. It follows that the energy consumption charge will increase with increased "lid-open" time, thus "lid-open" time should be no longer than absolutely necessary. The sama principles apply to opening the roof on an arc furnace.

- The use of on-load solid-state stepless power controls has the following advantages:

1. Furnace power can be maintained at a maximum level throughout the lining campaign.

2. Furnace power can be phased back exactly as required by the plant demand control system.

3. Furnace power can be phased back easily while tapping and charging which increases productivity.

A good furnace operator can save energy in many ways. Fast charging and slagging of the furnace, with minimum cover "open time", will save the most heat energy. Bringing metal to temperature shortly before it is dispatched to the molding line and not keeping the metal in the furnace at its highest temperature for a prolonged period of time will result in less heat losses via refractory and spout; an added advantage is prolonged lining life. With an automatic molding line operation, it would be practical to deliver metal to the pourer in constant intervala, and deliver only the amount of metal he can pour in the molds rather than 
gupply him with a congtant amount of metal he cannot pour off before it cools down to the polnt where pigging is required.

- Some foundaries melt off-peak and hold so that pouring can be completed during the day-shift, thereby reducing demand charge.

\section{MELT FURNACE IMPROVEMENT}

Electric Arc Furnaces

The axc furnace is a refractory-lined vessel. At the beginning of the melting cycle it is filled by swinging aride the movable refractory lined roof and dumping in a charge of metallic scrap. The electrical energy needed to convert this charge to liquid metal ia transmitted through aeveral electrical distribution componenta, ending with the electrodes in the arc furnace (see figure 2-5).

The furnace transformer takes the high transmisaion voltage and converts it into a lower operating voltage. The operator can choose from geveral operating voltage levels called "tap voltage".

Energy consumption, measured in kwh per ton, is fairly constant in mogt arc furnace operationg, ranging from 450 to $550 \mathrm{kwh} / \mathrm{ton}$ of charge, depending on the scrap type and length of heat. luts are few upportunities to decrease power consumption in electric arc furnace melting because the roof 1 s off only for charging. However, heat can be recovered from the cooling water or furnace stack. Scrap preheating is an effective energy and electrode saver, as is the use of oxy-fuel burners.

Energy cost savings however can be substantial by applying the following procedures:

- Off Peak Melting

- Demand Limiting

- Demand shifting

Energy conservation in arc melting is closely tied to power distribution, power demand regulation, furnace regulation and, most important, operating practices.

In a given furnace, the fastegt heat usually not only produces the most tonnage but also convertg energy most efficiently. The heat transfer at the arc should be optimized under various operating conditions. "Bore down" and "melt down" are normally best performed uaing maximum power for long arcs whose increased mobility speeds up the conversion of scrap to hot metal with minimum electrical losses. During meltdown, where the arc is surrounded by scrap, approximately 75 percent of all energy is used and thermal losses are at a minimum. During the refining period, when sidewalls are bare and only energy at a low power level is needed, to raise the bath temperature a few degrees, thermal los aes are correspondingly higher. 
Energy conservation in arc melting can be affected by many different variables. The most important ones are:

- arc furnace regulation - This system automatically lowers and raises the electrodes during the automatic mode of operation, always responding to the change in secondary current and voltage, and maintaining a pre-set distance between the electrode tip and the furnace charge. A regulating system which is not optimized can result in long and inefficlent heats, requiring additional energy.

- power system characteristics - Primary power distribution switching by the supply and power company can change the existing short-circuit capacity and perhaps the primary voltage which in turn affects the arc length, resulting in excessive electrode consumption or excessive refractory erosion. This type of variable will also affect furnace productivity resulting in a higher consumption of energy.

- operating delays - Interruption in melting, scheduled or unscheduled, by unnecessarily lengthening the heat time, reduces furnace output and adds to the thermal losses in melting and can greatly increase the consumption of energy.

- human element - People are responsible for most major problems or improvements in energy conservacion. Unnecessarily long, inefficlent heats caused by many different interruptions always require additional energy. Energy can also be wasted by not using optinum voltage selection or by inappropriate changing power input, power factor and current due to misuse of electrical control devices. More and more arc furnace melt shops are placing increased emphasis on operator training in order to achieve better production and improved energy conservation.

A power profile or power program, which takes into consideration the full equipment capability, can be used with or without automated operation to greatly improve overall melting performance and energy management. This program defines precisely when to change the power input characteristic or when to recharge by noting the consumption of energy ( $\mathrm{kw} / \mathrm{hr}$ ) in relation to weight and makeup of charge materlal. 

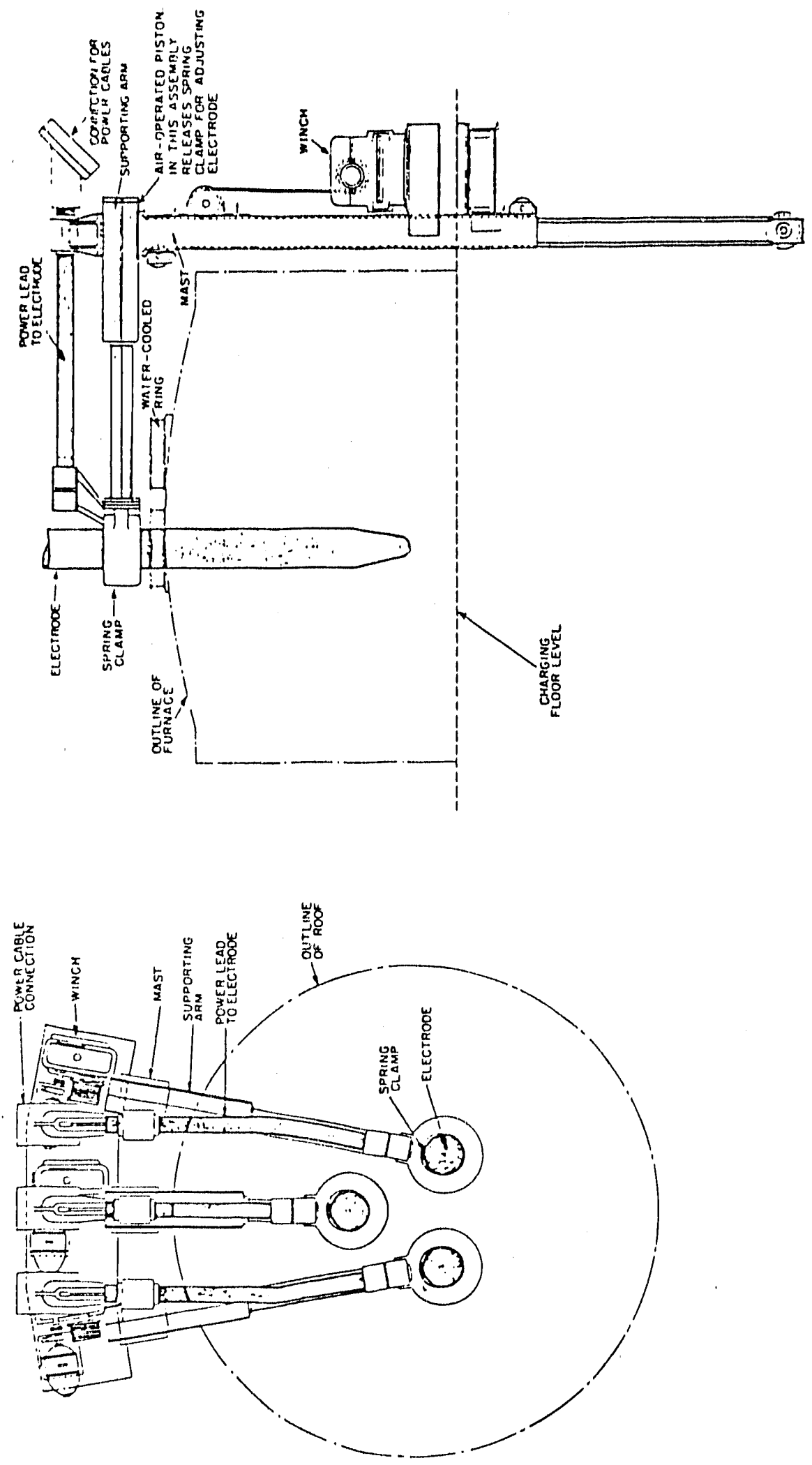

FIGURE 2-5. SCHEMATIC ARRANGEMENT OF THE ELECTRODES, THEIR SUPPORTING MASTS, AND THE ELECTRICAL LEADS FOR AN ELECTRIC-ARC STEELMAKING FURNACE 
Iron foundries that utilize electricity for melting use mostly coreless and channel type induction furnaces. All induction furnaces operate on the principle that when alternating current is passed through a coll, a magnetio field is created which induces eddy currents in a metal charge placed within that fleld. The degree of heating achieved is dependent on the rate of variation of the magnetic field (frequency) and on ita intensity (power).

Channel furnaces are used for melting and duplexing, the requirements to always keep a heel in the furnace and the limitations of inductor power level limita their application as a primary melter. Electrical efficiency of an inductor is $94-95$ percent, this is extremely high compared to coreless furnaces with a 76-81 percent efficiency.

Corelegs furnaces loose approximately one fifth of the total energy consumed to the cooling water system, therefore considerable work has been done to improve furnace design.

The use of profile "D" (see Figure 2- 5 ), for the power coil, reduces the penetration of magnetic flux lines through the outside corners which minimizes eddy current 108ses. Also, "D" profile allows the coil to be wound tighter with sufficient creepage distance which improves efficiency.

The cooling colls (Figure 2-7), on top and bottom, extract energy which should have gone into the melt. The use of newer castable backup refractory helps eliminate the need for cooling colls.

Electrical efficiency of the Induction furnace can be increased by as much as 108 with these improvements. A foundry ahipping 20 tons a day (at 50 yleld) can save approximately $\$ 20,000$ annually with 108 improvement in efficiency (cost of electricity 4 cent. kwh lncluding demand charge). 

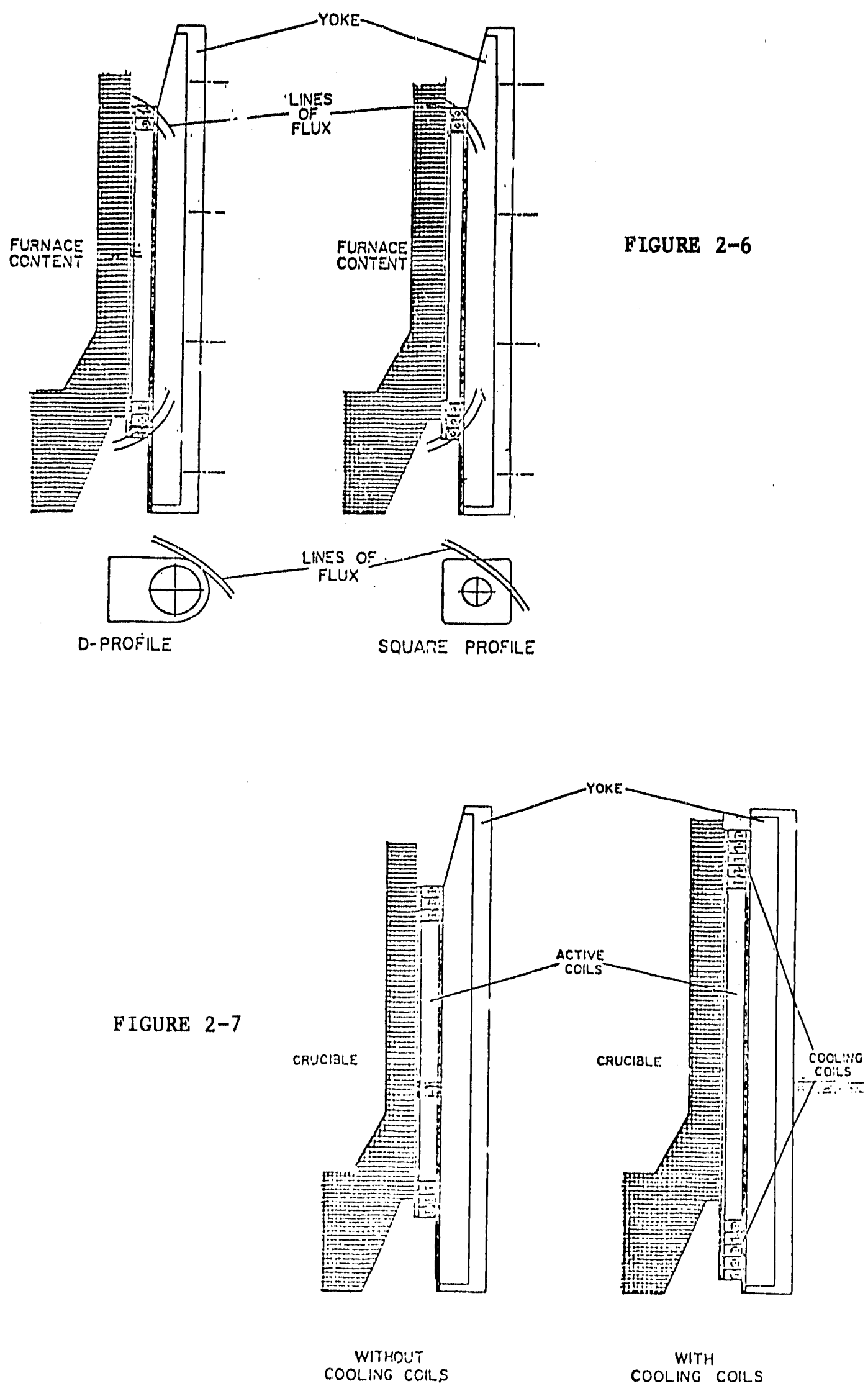
Eleotrio Reglatance Heated Reverberatory Melting Furnoge for Aluminum Meltingl.

Much like the fuel-fired furnace, the wleotric Reverberatory Melting Furnace (DRMF) is congtruoted with an aluminum-resiatant refraotory lining and atructural steel ahell. The total height of the furnace lo much lower because the bath depth 1. more shallow, and less apace la required above the bath. The furnace is heated by ilicon carbide or other realotance elemente mounted horizontally above the bath. Heat la transferred through direot radiation from the elements and radiation from the refractory roof and sides.

The second type ERMF metal melting syatem employs electrio immeraton type elements. The elemente are inserted into allicon carbide tuber which are immersed into the molten aluminum. Through radiation, the element passes 1ta heat to the silicon carbide tube and through conduction, the tube releases its heat into the bath. With the heating length of the element aix inches from the bottom of the bath, temperature uniformity is good. With this immersion type, heat does not have to be transferred down through the bath from the surface.

Because the electric furnace does not need a flue, the heating chamber can be made almost airtight with the only heat lose being through the shell and from exposed radiant metal surfaces. A well is provided for charging of scrap and solids so there is no need to open the accesa door to the main chamber.

Metal Melting Losg

The metal 108s from drogs, due to oxidation, is approximately one percent for $11,000 \mathrm{lbg}$. of aluminum metal. At the present metal cost of $\$ 1.00$ per pound this represents a very aignificant 108 , and potential for aavinga.

\section{Metal Quality}

With the melting of aluminum metal, low gas levels and minlmum oxide inclusions are a must. The only source of hydrogen gas in an ERMF is from the materlals being charged into the furnace. Treatment of gcrap and clean ingots keeps hydrogen gas at low levela.

\section{Working Conditiong}

Working conditions around an ERMF are vastly superior to gas-fired reverberatory furnaces, the two major differences belng nolse and heat. ERMF are practically noiseless, while a bank of gas-fired reverberatory furnacer creater noige levela close to OSHA limita of 90 decibela. The heat losg from a bank of gas-fired reverberatory furnaces is extremely high and could amount to approximately 15 times more than the ERMF. 
Uncovered charging and dip-out wells and bath radiate 20,000 $\mathrm{Btu} / \mathrm{ft}^{2} / \mathrm{hr}$ vs on $1 \mathrm{y} 500 \mathrm{Btu} / \mathrm{ft}^{2} / \mathrm{hr}$ for a covared well, a factor of $40 \mathrm{t} 1 \mathrm{mes}$. The importance of well covers in a holding altuation cannot be overemphasized.

Graphite Rod Holding Furnace

As the graphite rod holding furnace to not a primary melting furnace, this furnace will not be addressed with regards to cost savings. The efficlency and utilization of energy input to metal holding is high. The power factor 1s maintalned at near unity. With this type of unit not much design lmprovement is possible.

\section{Ladle Metallurgy}

In recent years, a great deal of emphasis has been placed on the concept of "Clean Steel Technology" in the steel foundry industry. Considerable research funding has been applled to the definttion and production of clean steel. From a foundryman's standpolnt, "Clean Steel" generally means low levels of sulfur and phosphorus, low gas content, and a minimum of inclusions, both macro and micro. These requirements are, of course, driven by the marketplace and these trends will continue.

These challenges have been met in the baslc steel industry through the use of varfous ladle refining technologles. These processes, however, have been difflcult to transfer directly to the foundry industry because of the small size ladles used in the typlcal foundry. These ladles are generally 5-ton capactty and smaller. Heat losses in small ladles are proportionally greater than for large ladles whlch severely reatricts the time avallable for ladle treatments. In addition, a reagent to be used for desulfurization or Inclusion control should have maximum time avallable for complete dissolution which implies introduction to the ladle at the very bottom and a sufficlent depth of metal to allow disoolution during the time avallable for flotation to the upper ourface. Small foundry ladles often do not have aufficlent depth to allow this to occur.

A further consideration 18 the nature of the slag cover on the ladle. Slags that are effective in lowering the sulfur and oxygen content often have relatively high melting polnts and tend to crust and be nonreactlve under the conditions described above. In order to overcome these problems, a good deal of work 1s in progress to develop viable foundry size ladle furnaces that would compensate for the heat losses and allow sufficlent time for effective refining.

It is apparent from the above discussion that these ladle refining processes all result in increased processing time in the ladle and temperature losses that at times may be quite severe. One method comoniy used to compensate for these heat losses is to tap the heat at a considerably higher temperature than otherwise required. However, to carry out extensive ladle refinting operations without some sort of reheating would likely result in temperature losses that would be too 
great to be compenated elmply by using a higher tap temperature. In addition, the use of a higher tap temperature reaults in excesalve energy conaumption, exceralve refractory wear and unnedeasary reoxidation.

The above constderationa, then, have j.w to the intereat in developing foundry olzed ladle furnace oapable compensating for heat loses during refining, melting subatantial alloy additiona, and oontrolling (Inoreasing if necossary) the pouring temperature.

Another feature of a foundry ladle furnace la that it la capable of incroaling productivity by performing a mafor part of the total heat cyole in a separate vesel. This allow the primary melting unit to perform the funotion that 1.t was deaigned for, that is, melting. Most melting furnaces, partioularly aro furnaces, are very lnefflolent refining vessels dise to shape, power input levela, and lack of atiring oapability. It is for this reason, that refining 1 more efflolently oonducted in a separate unit that is specifloally designed and equipped to perform these functions. The use of this concept can increase productivity in the melting operation by approximately 20-30 per cent.

\section{Plagma Flred Cupola}

A cupola is a vertical cylindrical shaft furnace which is conventionally used in the foundry industry for the production of cast iron. One of the main features of such a furnace is counter-flow preheating of the charge material by upward-flowing hot gases. Because the conventional cupola relies on the combuation of metaliurgloal ooke for its source of energy, the velocities of the gaaes are high. To avold entrainment of ocrap partioles in the flowing gas atream, briding and oxidation of mall - lze derap muat be avolded, limlting the flexlbility of cholce of melt materials. Finer materiale such as turnings and borings, which are much oheaper than conventional gorap, cannot be fed direotly into the cupola unlese they are flest briquetted, a costly and inconvenient procese.

In order to oiroumvent these problems, a plasma ilred oupola has been folntiy developed by Westinghouse, Modern Equipment, General Motorw, and EPRI. This oupola, a more-or-10se conventional oupol shaft furnace fltted with plasm torcher, has the diatinct advantage of providing the energy for iron melting independent of coke combustion. since the volume of plasma gas needed to introduce this energy la much smaller than the volume of coke combuation producta, the velocities of the gasea riaing in the plasma-fired cupola are relatively low. Therefore, low-cost charge materlals like borings and turnings can be fed directly into the cupola.

Beyond allowing the use of low cost charge materlals, the plasmaflred cupola has othex key benefita. The oxidation of alloy elements (ailicon, chromium, manganesis, etc.) and their corresponding lose to the olag la a costiy characteribtio of conventional cupolas. By using a plasma super-heated blast at the tuyere level of the oupola, a faster reaction rate between the carbon of the coke and the oxygen of the blast alr is realized, and $h i g h \mathrm{CO} / \mathrm{CO}_{2}$ ratios result. This produces a highly reducing atmosphere which reduces the oxidation 108seg. Therefore, the 
reoovery of the alloy elemente 1o Inoreaged. Moreover, the temperature in the bottom section of the oupola can be aignifleantly increased. With this, reducing oondition can be eatablished to a level sufflolent that allicon can be produoed through the reduction of allica. Procedures such as this are not practioal in oonventional oupolas. They apply the oombustion of ooke, ofl or gas and attain operating temperatures of the order of $3000^{\circ} \mathrm{F}$ maximum. With plasma technology, temperatures in the reaction zone can reach $10,000^{\circ} \mathrm{F}$.

Another economio benefit of the plasma-fired oupola id the increase in productivity due to the olgnifloantly higher operating temperatures. The melting capacity of a conventional oupola can be increaged by as much as fifty percent by using plasma as an energy souroe. Further, the startup of the plagma-fired oupola has been found to be much faster than the conventional cupola, thereby reducing labor cost.

The environmental benefits of the plasma-fired cupola are also noteworthy. Because of the avallablilty of electrical energy for the melting of the lron, coke consumption and thus the generation of combustion products, can be minimized. As a result, levela of environmental emiseions are reduced proportionately. Coke is required in the plasma-fired oupola to provide a source of carbon for the iron and to provide for the proper porosity of the charge materlal as it moves downward through the cupola shaft. It also contributes to the preheating of the upward flowing gasea. Coke combustion also provides a portion of the energy required for the iron melting. Using plasma, the proportions of electrical energy and coke coneumption energy can be optimlzed to achleve the lowest cost production on hot metal.

The initial experimental work Involved a pilot-scale test cupola using a single $1500 \mathrm{~kW}$ Westinghouse plasma torch at the Westinghouse Plasma Center located at the Waltz Mill site in Madion, Penneylvania. Based on the results of this work a commercial inatallation was constructed at the General Motora Central Foundry Diviaion plant in Defiance, Ohio.

This cupola, called the plagma Melter, began life as a conventional 13-ft.-diameter cupola and was retrofitted with $81 \times 1.5$ megawatt direct current Westinghouse plasma torches in the tuyere section of the cupola. Blast air volume was reduced from $25,000 \mathrm{cfm}$ for conventional operation to $10,000 \mathrm{cfm}$ in the Plasma Melter.

The Plasma Melter produced lron for its first castings in March 1989, and is now operating on a two-ghift basis with electrodes inspected and maintained over the weekends. The rated capacity of the Plasma Melter is 45 tons/hour.

This installation has been economically fustified on the basis of being able to use in-house turnings and borings as melt stock without costly briquetting. These economics may not apply to all foundries, however, this technology should find wide application and contribute to the profitability of many organizations. 


\section{Plasma Assisted Cupola}

A somewhat different approach to the use of plasma heating with cupola melting is the "Plasma Assisted" oystem developed by Aerospatiale in France. In this approach, a conventional hot-blast cupola was retrofitted with a plasma torch located in the wind box to serve as a supplemental heating device.

A demonstration study was conducted at the sept-Fons (France) foundry of Automobilea Peugeot by fitting a portable, 2 MW plasma torch to an existing 20 ton/hour hot-blast cupola. The current installation produces griy cast iron for mass-produced parts such as cylinder blocks, hub-drums, disc brakss and exhaust manifolds. Hot blast temperature (without plasma assist) ranges from $660-930^{\circ} \mathrm{F}$ depending on the blast rate.

The test campaign was run using hot-blast temperatures ranging from $1650-2370^{\circ} \%$ again depending on the blast rate. The principal advantage realized by this approach was the ability to use a higher percentage of low-rost steel scrap in the charge. In addition, Peugeot reported savings in coke consumption. Further, the use of oxygen enrichment was not required resulting in further savings. Based in Peugeot's figures, a payback period of 2.2 years was realized. The generally favorable results of this demonstration effort resulted in the commissioning of a $4 \mathrm{MW}$ production unit in 1988 . Operating results of this installation have not yet been reported in the literature.

Additional study of this approach is required, and it appears that the use of a lower preheat temperature may allow a lower cost installation as far as refractories, ingulation, etc. are concerned. This, in turn, would shorten the payback period - perhaps significantly. This approach has considerable merit and should be studied further with the goal of optimizing the relationship between preheat temperature and installation/ operating costis. 


\section{USAGE IN FOUNDRIES}

As atated previously in this study, a typical teel foundry uses up to 668 of its fuel energy input for gas fired equipment. In most foundries overall efficiency of melt furnaces, heat treat furnaces and ladle heating is about 20 or even lower which, in relative terms, means that for every 100 unite of gas energy input only 20 units are utilized to heat the product, the remaining 80 units are expended in furnace $108 \mathrm{ses}$ and exhaust losses, Figure 2-8.

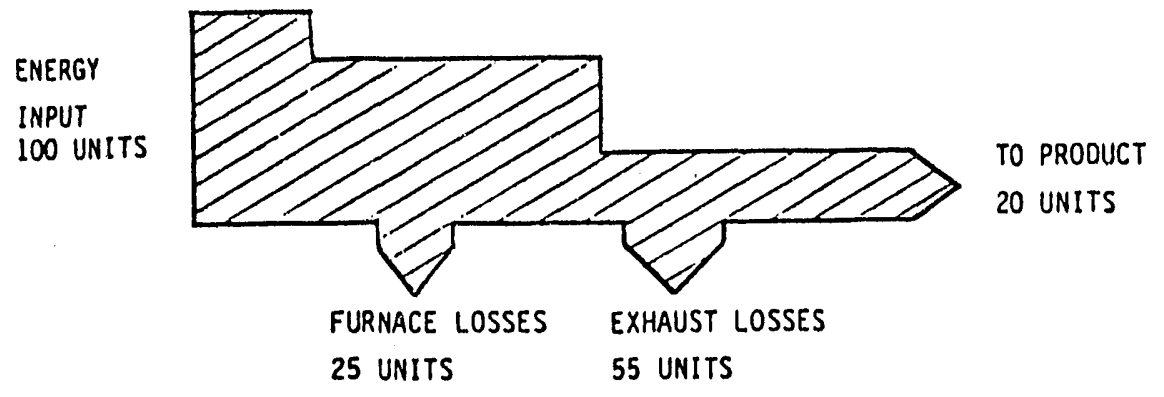

FIGURE 2-8 PROCESS ENERGY FLOW DIAGRAM

By drawing a process energy flow diagram, as illustrated above, one can actually see the mafor arean of concern. Once the above information has been developed, an energy flow diagram of the same procese under ldeal conditione can be developed. By comparing the actual diagram to the 1deal, one can further improve chances of maximizing energy uavinge while minimizing capltal inveutment.

While energy recovery 10 unually the flret area addreseed for onergy conservation, a closer look at the problem will usually prove that improvements in the combuetion ale to gas ratio, furnace presenure controla, ineulation, and refractory produce the bulk of the avallable onergy uavings at the least capital cout. 
Unlike electricity, gas utility bills are very simple to read, the following is a typical example of a monthly gas utility bill:

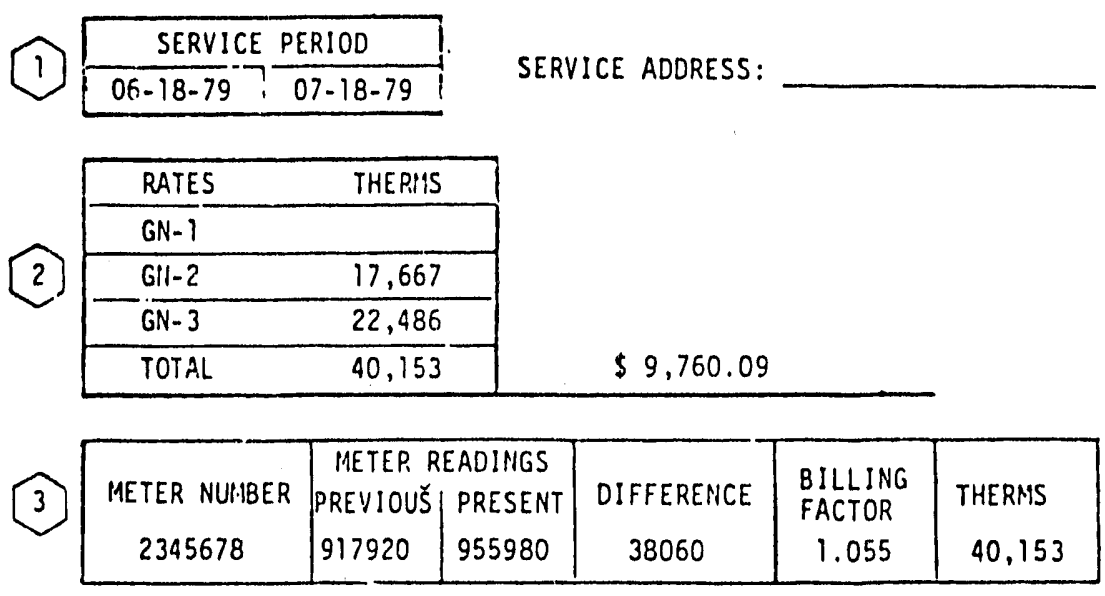

Box 1 is the service period on a monthly basis.

BoX 2 is the rate schedule and terms used.

Gas company rates are based on the following priority schedule:

- GN-1 is for residential and small industrial users consuming less than 100,000 cubic feet of gas per day.

- GN-2 is for industrial users consuming over 100,000 cubic feet per day and who have standby fuel capability.

Box 3 shows the actual months consumption in cubic feet of gas.

The billing factor is the actual heat content of the gas. (Can vary depending on location).

The final column is the amount of therms used for the month. Meter units are $100 \mathrm{cu}$. ft. (1.e., example equals 3,806,000 cu. ft.) 
Our hypothetical bill is interpreted as follows:

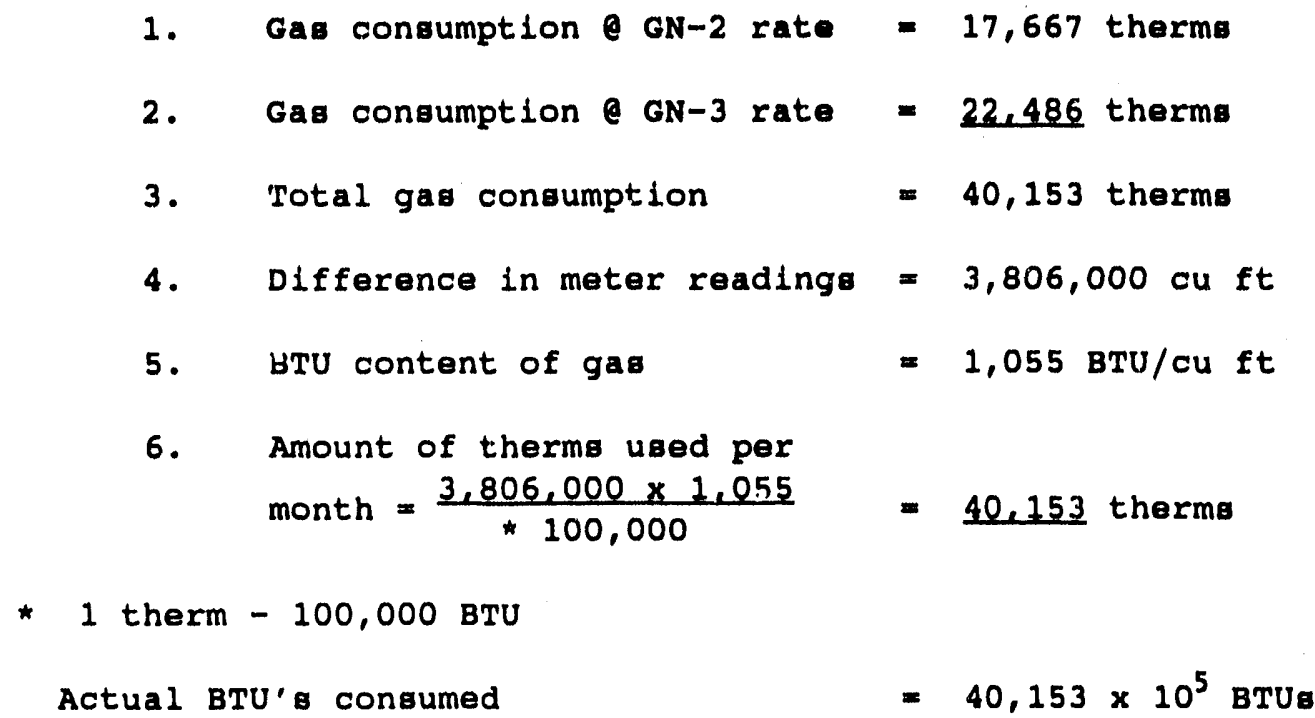

\section{IN PLANT METERING}

The monthly gas utility bills show how many Btu's have been expended to produce a product, what the bill does not tell you is where the Btu's were used in a particular gas consuming process.

As the nation's energy requirements grow, the Foundry Industry can expect to pay even more for gas in future years. Foundries that will remain dependent upon gas for their production processes will be placing even greater emphasis on in-plant conservation efforts in order to achieve maximum production efficiency from this lncreasingly expensive fuel.

Cost allocations, within departments, and fuel surcharges to customers will become commonplace. Close monitoring of allocated supplies will become a necessity in energy management.

The basic and most important tool in energy management is an energy monitoring system. Before energy can be saved, an accurate metering system must be established in the foundry to determine exactly how and in what quantities, energy is being used, considerable savings can be realized almost immediately from the data derived from an energy audit using in-plant metering.

Gas consumption monitoring can also be advantageously used to control oven or furnace temperatures and prevent over-temperature damage. Also equipment problems can be detected before they cause emergency shut down.

Measuring fuel consumption alerts maintenance crews to a variety of potential problems such as:

- Leaking fuel lines 
- Faulty temperature measuring devices

- Faulty rellef valves

- Excessive burner cycling

- Warped furnace doora

- Deteriorating furnace insulation

A relatively low cost monitoring device is the "Annubar". This device is a primary flow aensor deaigned to produce a differential preseure that is proportional to flow. The flo-tap annubar can be inserted and removed from operation without gystem shut down.

Annubar can be interfaced with secondary devicea, a standard flow meter is available for rate of flow indicalion. It can be used as a portable meter or permanently mounted.

Annubar connected to a differential pressure transmitter (Electric or Pneumatic) is used with a variety of atandard secondary equipment for totalizing, recording or controliling complex systems.

\section{OBTAINING A COMBUSTION ANALYSIS}

In order to determine the operating efflciency of melt and heat treat furnaces. it is imperative that a flue gas analygis be made. One of the best ways available for obtaining a flue gas analysis for $\mathrm{CO}_{2}$ and $\mathrm{O}_{2}$ is the use of a comburtion analyzer.

In most actual combustion processes the determination of correct air-fuel ratio cannot be made by direct. measurement of entering air, since various leakages through auxiliary openings will be responsible for a substantial increase in total air over that metering at the burner, thus for practical purposes the air-fuel ratio must be determined by calculation from data available, hence the combustion analyzer.

The flue gas data resulting from a combustion analysis are used with suitable charts (see section 3) for determining the percent excess air and, together with the information on flue gas temperatures, to determine the heat lost in the stack.

(N.B. pages $2-28$ and $2-29$ have been deleted) 
Accurate measurement of high temperatures 18 one of the most critical factors in determining equipment performance and process efficlencies of energy consumption in foundries, high temperatures are defined as those between 700 and $3,500^{\circ} \mathrm{F}$.

Sensors used to measure elevated temperatures are classiffed as efther contact or non-contact. Contact sensors include thermocouples, resistance temperature detectors, bimetallic thermometers, thermistors, and filled systems. Non-contactors include optical and radiation pyrometers. Thermocouples are used in a large number of the applications in industrial plants.

Portable thermocouples of various deslgns are avallable. The instruments are compact, 11ghtwelght, and battery powered, and they can easily be carried around the plant to measure process or equipment temperatures easily. Most models have a variety of interchangeable thermocouples sensors and multiple temperature selector switches to provide maximum versatility. (See table 2wI for comparisons).

TABLE 2-I. COMPARISON OF COMMON THERMOCOUPLES

\begin{tabular}{|c|c|c|c|}
\hline Type & $\begin{array}{l}\text { Usable } \\
\text { Temperature } \\
\text { Range }\end{array}$ & Advantages & Restrictions \\
\hline $\begin{array}{l}\text { Type J } \\
\text { (Iron- } \\
\text { constantan) }\end{array}$ & $\begin{array}{l}-300 \text { to } \\
1500 \mathrm{~F}\end{array}$ & $\begin{array}{l}\text { Comparat ively inexpensive. } \\
\text { Sultable for continuous } \\
\text { service to } 1600 \mathrm{~F} \text { in neutral } \\
\text { or reducing atmospheres. }\end{array}$ & $\begin{array}{l}\text { Moximum upper limit in } \\
\text { oxldizing dtinosphere is } \\
1400 \mathrm{~F} \text { because of the } \\
\text { oxidation of the iron. } \\
\text { Protection tubes should }\end{array}$ \\
\hline
\end{tabular}
be used doove $900 \mathrm{~F}$.

protection tubes should always be used in a contaminating medium.

\begin{tabular}{|c|c|c|c|}
\hline $\begin{array}{l}\text { Type k } \\
\text { (inickel, } \\
\text { chromiun- } \\
\text { nickel, } \\
\text { d luminum) }\end{array}$ & $\begin{array}{l}010 \\
2500 \mathrm{~F}\end{array}$ & $\begin{array}{l}\text { Suitable for oxidizing } \\
\text { dtmospheres. } \\
\text { In higher temperature ranges, } \\
\text { provides a more mechanically } \\
\text { and thermally rugged unit } \\
\text { then plat inum or rhod lum.- } \\
\text { platinum, and longer life } \\
\text { than iron-constantan. }\end{array}$ & $\begin{array}{l}\text { Especially vulnerable to } \\
\text { reduc ing dtinospheres. } \\
\text { requiring substintial } \\
\text { protection when used. }\end{array}$ \\
\hline $\begin{array}{l}\text { Type Y } \\
\text { (Copper- } \\
\text { constantan) }\end{array}$ & $\begin{array}{l}-300 \mathrm{~F} \\
700\end{array}$ & $\begin{array}{l}\text { Resists atmospheric corrosion. } \\
\text { Applicable in reducing or } \\
\text { oxidizing dtinuspheres below } \\
600 \mathrm{~F} \text {. } \\
\text { Stability makes it useful at } \\
\text { subzero temperatures. } \\
\text { Has high conformlty to } \\
\text { published calitidtion data. }\end{array}$ & $\begin{array}{l}\text { Copper oxidizes above } \\
600 \mathrm{~F} \text {. }\end{array}$ \\
\hline $\begin{array}{l}\text { Type E } \\
\text { (ilickel. } \\
\text { chromium- } \\
\text { constantan) }\end{array}$ & $\begin{array}{l}-300 \text { to } \\
1600 \mathrm{~F}\end{array}$ & $\begin{array}{l}\text { Has nigh thermoelectric } \\
\text { power. } \\
\text { Both e lements are highly } \\
\text { corrosion-resistant, permitting } \\
\text { use in oxidizing atmospheres. } \\
\text { Does not corrode at suosero } \\
\text { temper atures. }\end{array}$ & $\begin{array}{l}\text { Stabllity is unsat is. } \\
\text { factory in reducing } \\
\text { dtmospheres. }\end{array}$ \\
\hline
\end{tabular}


TABLE 2-I (CONTINUED)

\begin{tabular}{|c|c|c|c|}
\hline Type & $\begin{array}{l}\text { Usable } \\
\text { Temperature } \\
\text { Range }\end{array}$ & Advantages & Restrictions \\
\hline \multirow{2}{*}{$\begin{array}{l}\text { Type s } \\
\text { (plat inum, } \\
\text { io\% rhod fum- } \\
\text { plat I num) }\end{array}$} & \multirow[b]{2}{*}{0 to } & $\begin{array}{l}\text { Usable in oxidizing atmos. } \\
\text { pheres. }\end{array}$ & \multirow{4}{*}{$\begin{array}{l}\text { Eastly contaminated in } \\
\text { other than oxidizing } \\
\text { atmospheres. }\end{array}$} \\
\hline & & $\begin{array}{l}\text { Provides a higher usable range } \\
\text { than Type } K \text {. }\end{array}$ & \\
\hline $\begin{array}{l}\text { Type R } \\
\text { SPlat inum, }\end{array}$ & $2700 \mathrm{~F}$ & $\begin{array}{l}\text { Frequent ly more practical } \\
\text { than noncontact pyrometers. }\end{array}$ & \\
\hline platinum) & & $\begin{array}{l}\text { Has high conformity to } \\
\text { published calibration data. }\end{array}$ & \\
\hline \multirow{4}{*}{$\begin{array}{l}\text { Type B } \\
\text { (Plat inum, } \\
\text { 30x rhodium- } \\
\text { plat inum, } \\
\text { ox rodium) }\end{array}$} & \multirow[t]{4}{*}{$\begin{array}{l}1600 \text { to } \\
3100 \mathrm{~F}\end{array}$} & $\begin{array}{l}\text { Better stabllity than Type } S \\
\text { or R. }\end{array}$ & $\begin{array}{l}\text { Avallable in standard } \\
\text { grade only. }\end{array}$ \\
\hline & & Increased mechanical strength. & High-temperature $1 \mathrm{imit}$ \\
\hline & & $\begin{array}{l}\text { Usable at' } h \text { lgher temperatures } \\
\text { than Type } S \text { or R. }\end{array}$ & $\begin{array}{l}\text { requires the use of } \\
\text { plumina insulators and } \\
\text { protestion tubes. }\end{array}$ \\
\hline & & $\begin{array}{l}\text { Reference-junction compensa- } \\
\text { tion is not required if junction } \\
\text { temperdure does not exceed } \\
\text { l50 F. }\end{array}$ & $\begin{array}{l}\text { Easily contiaminated in } \\
\text { other than oxidizing } \\
\text { atmospheres. }\end{array}$ \\
\hline
\end{tabular}

\section{BURNER COMBUSTION EFFIC IENCY}

Conserving fuel in melting, heat treating and ladle heating operations is a complex operation. It requires careful attention to the following:

- Refractories and Insulation

- Scheduling and operating procedures

- Preventative maintenance

- Burners

- Temperature controls

- Combustion controls

Providing the correct combustion controls will increase combustion effictency measurably. Complete combustion of Natural Gas Yields:

(a) Carbon d toxide

(b) Water vapor

If gas is burned with the chemically correct amount of air, an analysis of the products of combustion will show it contains about 11 to 
$128 \mathrm{CO}_{2}$ e 20-228 water vapor. The remainder is nitrogen, whioh was present in the alr and passed through the combustion reaction esentially unchanged.

If the same sample of natural gas is burned with less than the correct amount of air ("rloh" or "reducing flre"), filue gas analygle will show the presence of hydrogen and carbon monoxide, products of incomplete combustion. Both of these gases have fuel value, so exhausting them from furnaces is a waste of fuel. (See Figure 2-9)

If more than the required amount of alr le used (lean or oxidizing flame), all the gas will be burnt but the products of combustion will contain excess oxygen. This excess oxygen is an added burden on the combustion system - it is heated and then thrown away thereby wasting fuel.

The following steps should be taken to upgrade burner and combuation controls:

1. Use sealed-in burners. Make all combustion air go through the burner - open cage type burnerg are very inefficient.

2. Use power burners. Insplrator or atmosphere burners have very poor mixing efficiency at low inputs, especially if gas pressure is low.

3. Install a fuel/alr ratio control system.

\section{PREMIX BURNER SYSTEMS}

Premix burner systems commonly use a venturi mixer known as an aspirator or proportional mixer. Air from the blower pasees through the venturi, creating suction on the gas line and drawing in the correct amount of gas at reduced firing rates, air flow is cut back, reducing suction on the gas line, and the amount of gas drawn into the mixer drope in proportion to air flow. Aspirator systems are falrly simple to adjust and maintain accurate fuel/atr ratios over wide turndown ranges, but their use is limited to premix burners. (Figure 2-10)

\section{NOZZLE MIX BURNERS}

Nozzle mix burnerg used with a Ratio Regular System is widely used for industrial furnace applications. Orifices are installed in the gas and air lines to a burner and then adfusted so that air and gas are in correct burning proportions when pressure drops across the orifices are equal. Once the orifices are set, they will hold the correct air/ga日 ratio as long as the pressure drop remains the same, no matter what firing rate. Ratio Regulator systems have good accuracy and are fairly easy to adjust. (Figurs 2-10)

On large furnaces where fuel consumption is extremely high, or on furnaces where very close control of the atmosphere is raquired, extremely accurate fuel/air ratio control is vital, both for fuel economy and product quality. On these installations hydraulic or electronic flow controls are often used. 
FIGURE 2- 9 PERCENT EXCESS AIR FROM $\mathrm{CO}_{2}$ READING

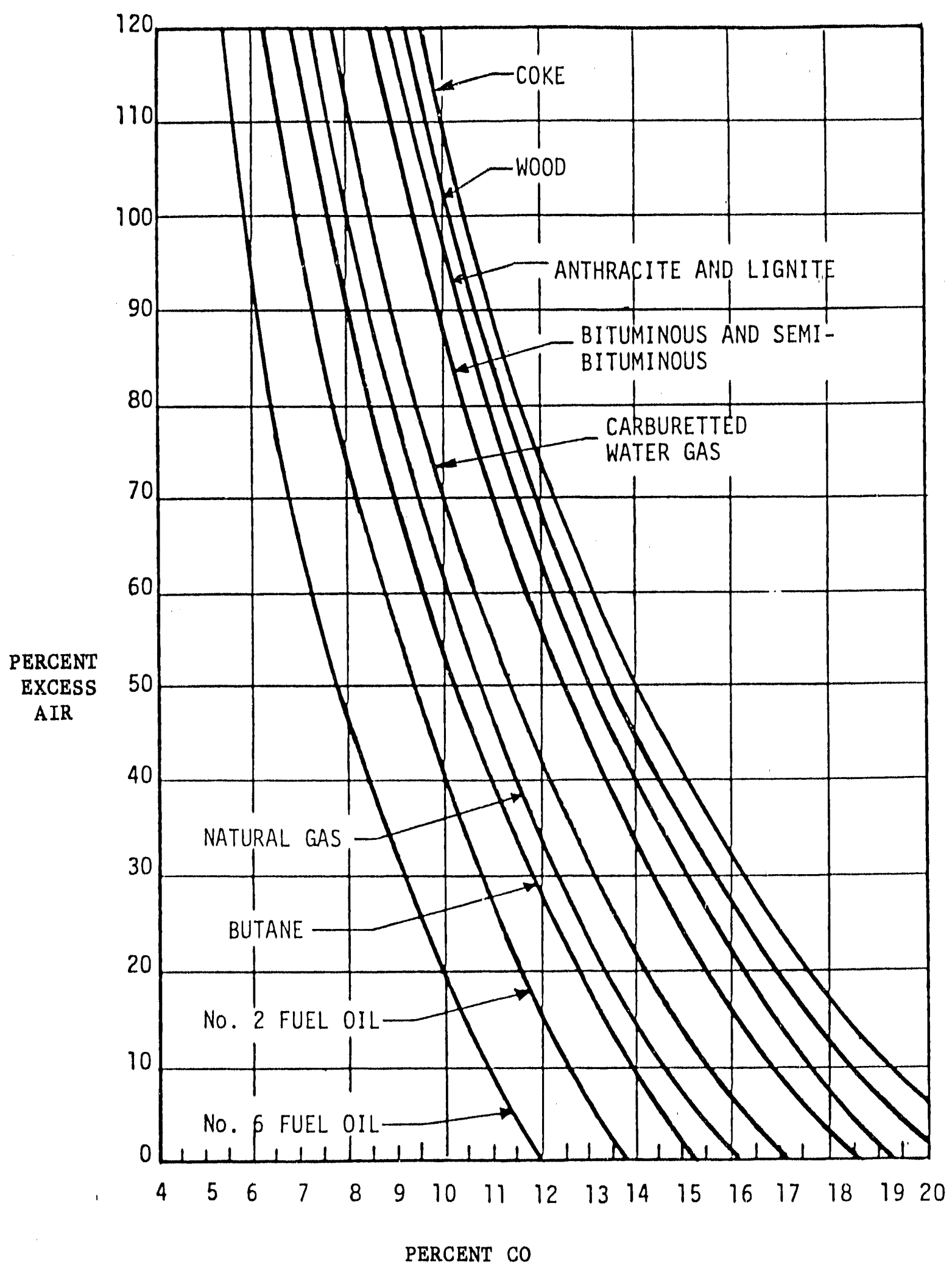



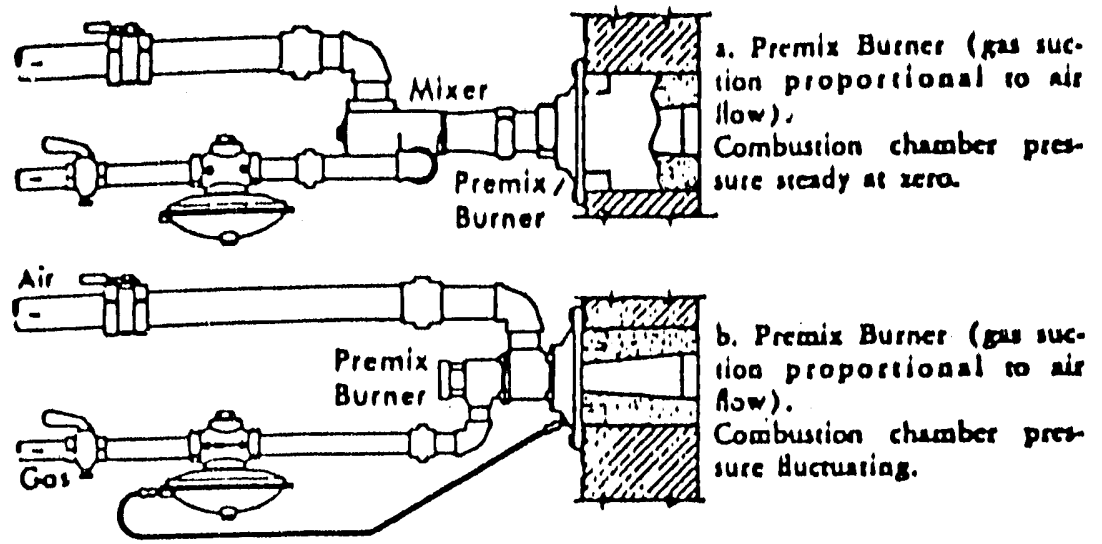

b. Premix Burner (ous suce lioo proportional to ais how).

Combustion chromber prer sure Huctuatiag.

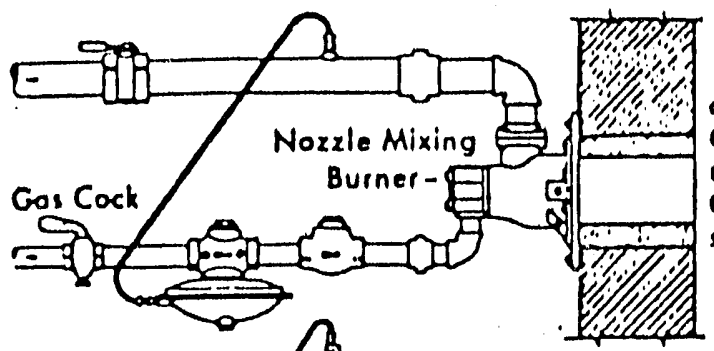

c. Nouxle Mixing Burner. Gas pressure $=$ or gecate than sir peessure. Combuscioa chumber pres sure siendy or Gurruaciog.

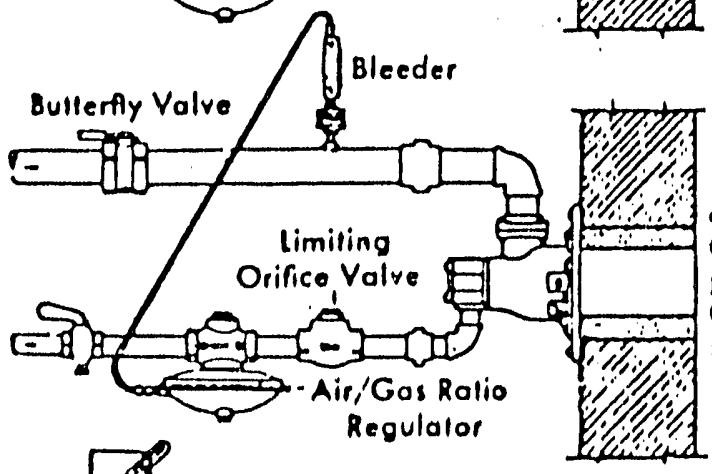

d. Nozsle Mixing Burner. Gas presure lowe than air persisuse.

Combusion chamber pres. sure neady at zera.

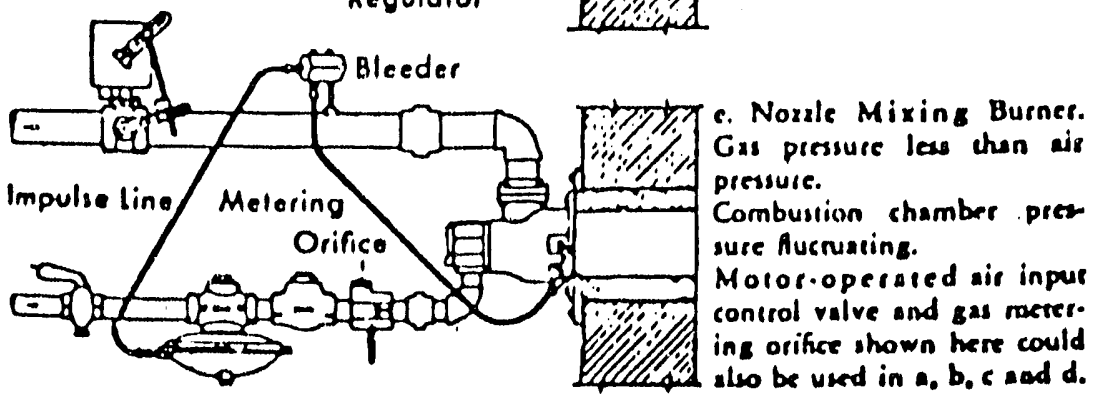

FIGURE 2-10 TYPICAL GAS/AIR REGULATOR HOOK-UP 
These aystems feature fixed orifloes in both gas and als atreams, and these orteloes are szed to pase proportional amounts of gas and atr at equal pressure drops, pressure drop ignals are fed to a ratio controller which comparea them. One of the outatanding featurea of thig oystem 1 that the fuel/air ratio can be adjusted by turning a dial. since burner can be thrown of correct gas ratlos by ohangea in amblent air temperature and humidity, thio ratio adjuatment foature permits the operator to get the burner baok to peak operating efflolenoy with very little effort.

On multiple burner furnaces, the combuation products of all burners $\mathrm{mix}$ together before they reach the flue gas ampling point (Furnadea ghould have mantfolded lue gas outlets in order to obtain common aampling point for flue gas analyaia). If, for exampl,a, oome of the burners are unintentionally set lean, and others rloh, the exoess alr from the lean burners could consume the exdeds fuel from the rloh burners, producing flue gas with ultimate $\mathrm{CO}_{2}$ and practically no free oxygen or combuatiblea. Samples of these gases could be mleleading and show correct alr/gas ratio, when in fact they are not. Also if a burner 1 s get rioh and the exoess combustibles in the flue gager find air in the staok and burn there, flue gas analyale will again auggest that the burner 18 properly adfusted.

To overcome the problem of misleading flue gas analysis in multiburner furnaces, metering orffloes ghould be installed on the gas lines to each burner. If pressure drope acrose all oriflcea are ldentioal, gas flow to each burner will be the same.

\section{FURNACE PRESSURE CONTROLS}

Furnace Pressure Controls will afford additional energy aavinga, partloularly on top-flued furnaces. If a furnace operates under negative pressure, cold air is drawn into it through badly fltted doors and cracks. This oold air has to be heated, adding to the burden on the combustion system and wasting fuel. If the furnace operates at high positive pressure, flames will sting out through doors, site porta and other openings, damaging refractorles and buokling shells. Ideally a neutral furnace pressure overcomes both these problems.

Automatio furnace preagure controle maintain a pre-determined pressure at hearth level by opening or closing dampera in response to furnace pressure fluctuations.

In summation; good fuel/air ratio control equipment and automatio furnace preseure controls are two useful weapons for combating gas energy wastage in heating operations.

Properly applied, they also offer the side benefite of improved product quality and shortest possible heating oyoles. 


\section{FURNACE EFF ICIENCY}

Conventional refractory linings in heating furnaces can have poor Insulating abilitles and high heat storage characterlstics. Baslc methods avallable for reducing heat storage effect and radiation $1088 e$ in melt and heat treat furnaces are:

1. Replace atandard refractory linings with vacuum-formed refractory fiber ingulation matertal.

2. Install flber liner between standard refractory lining and shell wall.

3. Install ceramlc flber lintings over present refractory 1iner.

The advantages of Installing refractory fiber insulation are:

- Refractory flber materlals offer exceptional low therma1 conductivity and heat storage. These two factors combine to offer very substantlal energy aavings in cruclble, reverberatory and heat treat furnaces (documented savings - 35\% or better).

- With bulk densities of 12-22 lbs./cuft, refractory flber linings weigh $8 \%$ as much as equivalent volumes of conventional brick or castables.

- Refractory flbers are restative to damage from drastc and rapld changes in temperature.

- Fiber materials are simple and fast to Install.

- The density of flber refractory 1s low, so there 1s very 11ttle mass in the lintig, therefore much less heat 18 supplied to the lining to bring it to operating temperature. This results in rapld heating on the start-up. Conversely, cooling 18 also rapld, since there is less heat stored in the lining.

- More comfortable working environment 1s attalnable due to Lower shell surface temperatures.

The basic design criterla for flber lined cructble furnaces are the same as used for furnaces lined with dense refractorles. Two rules should be followed:

1. The midpoint of the burner should be at the same level as the bottom of the cructble, and the burner ahould fire tangentially into the space between the cructble and lining.

2. The space between the out 81 de of the cructble, and the furnace lining near the top should be about $10 \%$ of the crucible dlameter. 
Cruobble furnaces oan be construoted using a combination of fiber with denge refractory or almost entirely out of flber. Inoreasing the proportion of flber will lnorease the energy arings and maximize the other benefita previously 11 sted.

Flber materiale are avaliable in varyling thioknesag, aultable for a complate monolithio inataliation, and oomporition to handie $2,400^{\circ} \mathbf{F}$. $2,600^{\circ} \mathrm{F}$, and $2,800^{\circ} \mathrm{F}$.

The higher temperature compositiong oontaln high alumina fiber. whioh lowerg the amount of ahrinkage at elevated operating temperaturea.

\section{FURNACE COVERS}

If preheating of combustion air utilizing furnace flue gas temperaturer is contemplated, Inatallation of furnace coverg 18 niandatory. The diffloulty in the past, in the fabrioation and use of furnace oovera, har been the problims of thermal shook and apaliling, materlala avallable today, suoh as refraotory fiber, have eliminated these problems.

In addition to technologioal advantages of fiber insulations. industry has also developed the capability of vacuum forming these materials over a varlety of metallio gupport atruaturea. Fiber insulation can be formed over elther expanded metal or angle iron frames, or both. with V-type anchors attached. The anchors are made from high temperature alloys, holding the flber to the metallio support structures to provide an Integral, fully secured assembly. No part of the anohor system is exposed to excessive temperatures, this eliminater attachment problems for ladle pre-heaters, oruoble furnace covers, and Induotion furnace covers. Ingtallation of furnace covera improves the thermal efflolency of the procese by approximately 50\%. 
Non-Ferrous Foundrles utilize three basto furnace types for melting and holding. They ares

- Gas firad oruolble

" Gag fired reverberatory

- Eleotrio reverberatory

The atationary oruoble furnace 1. primarliy used for aluminum, copper, and brass alloys. Its veraatility in allowing alloy ohanges makes it a desirable furnace for amall foundries where woh metal ohangeover in neceraary. Combuation burners are located so the flame is tangential to the orucible in order to avold direct flame impingement againat the oruoble wall. Blggeat diadvantage, other than therinal efflolencles, are short orucible 11 fe.

Fuel fired reverberatory furnaces are uad 2 ?! chosen when melt rate and/or capacity is such that a orucible would be too amall. The reverberatory is direct flred from elther the roof or oldewall with gas, propane, or oll burners (for tile purpose of this atudy the relative cost per BTU 1 asgumed as being e(fual). The heat 1s transferred to the bath by a combination of convection and radiation.

\section{IPGRADING GAS FIRED FURNACES}

1. Replace brlok or castable refractory with vacuum-formed refractory fiber on gas fired oructbles.

Example -- Arrow Casting and Development Co., in Santee, Callfornia, installed fiber liners on two - $425 \mathrm{lb}$. crucibles - documented 358 gaving in fuel. They can now produce a melt in one hour from cold gtart as compared to $2-1 / 2$ hours with conventional refractory liner-payback perlod - 6 munths.

Other advantages:

- Faster turn around time at reline time

- Lower shell temperatures (500 to $350^{\circ} \mathrm{F}$ )

2. Add fiber ingulated liner between atandard refractory liner of shell casing.

3. Update combustion controls (se burner combustion efflcienoy discussion)

4. Install furnace covers (see furnace cover discussion) 
5. Other miscellaneous changes that can be accomplished to improve furnace efficiencies.

- Reduce flus openiugs to a minimum, the correct design is 20-30,000 BTU per. square inch

- Optimize burner equipment maintenance

- Maintain clean blower filters

- Keep flues and slag hole clear

\section{HEAT TREAT FURNACES}

Heat treating is the eecond most energy intensive operation in many foundries. A comprehensive energy management program is mandatory as gas and oil costs continue to grow and diminish in supply. (Some foundries perform no heat treating.)

It is safe to say that many heat treat facilities in the foundry industry are not in particularly good operating shape. Minimum attention is paid to combustion efficiency and refractory maintenance.

Upgrading heat treat furnaces in the following areas will yield tremendous fuel savings:

- Replace existing burners with a modern pre-mix burner system

- Install efficient burner controls

- Install furnace pressure controls

- Replace conventional refractory lining with fiber insulation

- Seal all cracks and openings in casing and doors

- Install combustion air pre-heat system

Each of the above categories is related and dependent upon the state of the others, but will show an energy savings when individual improvements are made. Energy savings can be considered additive when an all out improvement program is implemented.

Process Operation and Control

Heat treat operations fall into two major categories - continuous and batch type. Ignoring specific casting requirements, restricting one process over the other, the continuous operation is favored from an energy conservation standpoint. With continuous operation, the furnace remains at equilibrium and is not heated and cooled and reheated with every new batch processed. The heat required to bring refractory up to various furnace temperatures and the heat lost through the furnace walls to the 
surrounding amblent temperature, besed on varying thicknesses of refractory, is 11lustrated:

TABLE 2-II HEAT STORAGE AND LOSSES BTU SQ. FT.

\begin{tabular}{|c|c|c|c|c|c|c|c|}
\hline \multirow{3}{*}{$\begin{array}{c}\text { HALL } \\
\text { THICKNESS }\end{array}$} & \multirow{3}{*}{ TYPE REFRACTORY } & \multicolumn{6}{|c|}{ HOT FA.CE TEMPERATURE ${ }^{\circ} \mathrm{F}$} \\
\hline & & \multicolumn{2}{|c|}{1,200} & \multicolumn{2}{|c|}{1,600} & \multicolumn{2}{|c|}{2,000} \\
\hline & & H. ST. & H.L. & H. ST. & H.L. & H.ST. & H.L. \\
\hline 9" & $\begin{array}{l}\text { Composite } \\
2,000^{\circ} \text { insulation } \\
\text { and firebrick }\end{array}$ & 13,700 & 285 & 19,200 & 437 & 24,800 & 615 \\
\hline $13-1 / 2^{n}$ & $\begin{array}{l}\text { Composite } \\
2,000^{\circ} \text { insulation } \\
\text { and firebrick }\end{array}$ & 22,300 & 335 & 31,400 & 514 & 40,600 & 718 \\
\hline $22-1 / 2^{\mu}$ & $\begin{array}{l}\text { Composite } \\
2,000^{\circ} \text { insulation } \\
\text { and firebrick }\end{array}$ & 43,200 & 182 & 61,000 & 281 & 79,200 & 392 \\
\hline $6^{\circ}$ & Ceramic fiber & 842 & 208 & 1,170 & 432 & 1,490 & 672 \\
\hline
\end{tabular}

Condensed from mark's handbook

B.ST - - Amount of heat stored

H.L. -- Amount of heat lost (Btu/Sq Ft)

The following information on present operating characteristics is necessary in order to evaluate present furnace efficiencies:

- Fuel flow rate in cublc feet per hour (gas) and gallons per hour (oil).

- Gas or o1l usage (by metering) per operating day or week (preferably from fire-up to shut down).

- Casting through-put in tons per hour for the same period.

- Fuel cost in dollars per million BTU's.

- Operating cycle, hours per load, and casting load in tons.

- Furnace operating temperature, waste flue gas temperature, and outside shell temperature.

- Types of existing burners, ratings, and percent of excess air (determined by flue gas analysis).

The above information can be used to determine existing heat input In BTU's per pound of castings processed and, calculate the anticipated heat input after replacement or renovation of existing furnaces. Such 
calculations form the basis of return on investment calculations that will permit a decision based on economical justification.

\section{LADLE HEATING}

The third largest gas consuming process in the foundry industry is ladle preheating. Most foundries use open ladles with Torch Type Gas Burners. Upgrading present ladle heating methods utilizing the following recommended procedures will result in substantial gas energy savings:

- Change unregulated Torch Type Burners to gas/compressed air type regulators.

- Install insulated covers.

- Add insulating lining between conventional refractory and shell.

Ladles come in numerous sizes and shapes, lined with castable or brick refractory or a combination of both. They are first heated slowly to expel moisture, without damaging refractory, until they are dry, then the heating rate is increased to allow refractory surface temperature to reach 2,0000 to $2,400^{\circ} \mathrm{F}$, primarily to reduce thermal shock to the lining and reduce temperature losses of the metal during pouring. Ladle practices vary largely from one cast metal facility to another. The practice is always energy intensive and what used to be good practice of a well operated shop, to have clean-heated ladles on standby at all times, is poor practice from the standpoint of energy management. The situation of high energy losses becomes progressively more serious when foundries use ancient, dilapidated, or homemade gas torches versus the latest stateof-the-art combustion equipment.

Ladle heating Equipment may be oil or gas fired or a combination of both; electric ladle heating is discussed under "Major Process Changes". see section $H$ Part 2 .

Generally, more efficient heating and drying systems and practices are possible in shops using large ladles where fixed ladle heating stations with covers or hotwalls with fully piped burners are being used. The tollowing diagrams show examples of fixed and wall type ladle s: ations. 


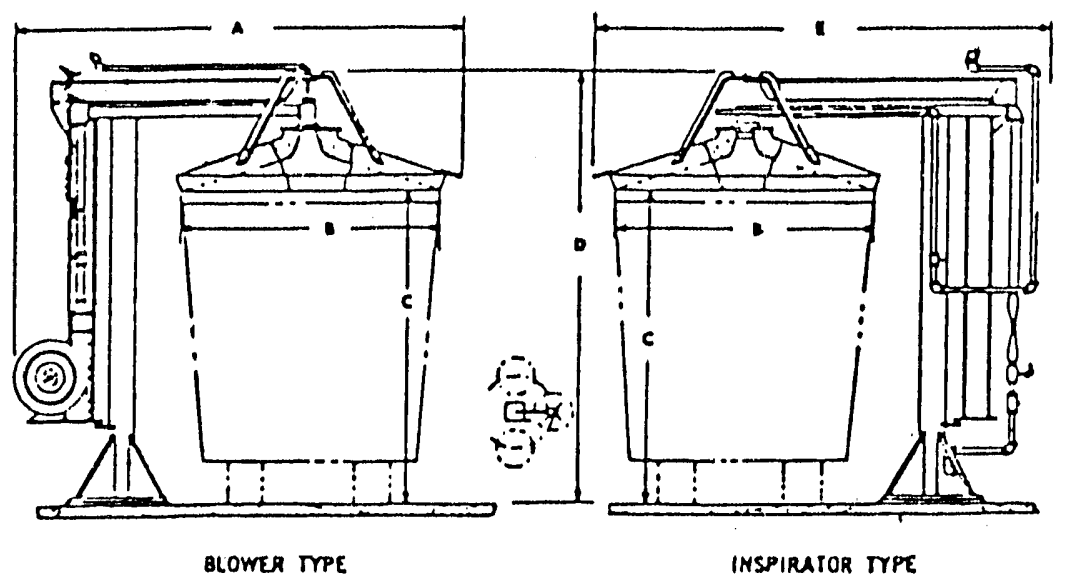

FIGURE 2-11 FIXED TYPE LADLE HEATING STATION

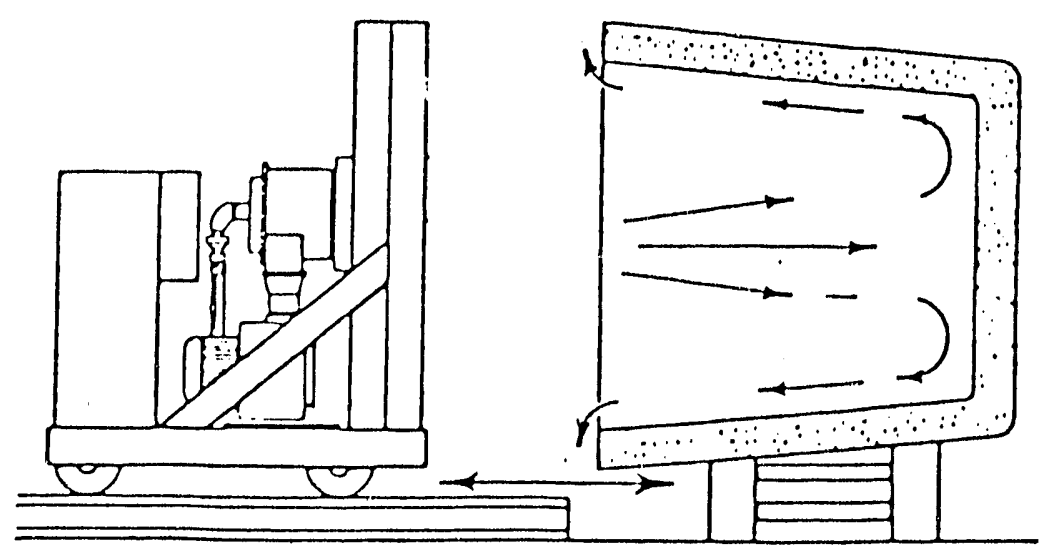

FIGURE 2-12 WALL TYPE LADLE HEATING STATION 
With many small foundry operations, the logistics and number of ladles handled make it difficult to maintain fixed burner stations using full alr/gas controls. Often portable torches are propped up on the ladle rim, gas flow rates are regulated by means of manual ball or gate valves. Gas consumption can be reduced by two thirds if regulated compressed air 18 added.

A foundry in the midwest installed regulated compressed air in a 500 pound ladle for drying and heating, they now use $220 \mathrm{cu}$. ft. of natural gas per hour compared with $660 \mathrm{cu}$. ft. when using open gas torch only.

The other option for smaller foundries is to substitute electric ladle heaters - see Section 2 part $\mathrm{H}$ for further discussion relative to electric versus gas ladle heating.

Potential Indirect energy reduction, due to control of metal temperature in the ladle by utilization of insulation and covers is possible due to control of pouring defects from cold metal and reduction in super heat necessary for metal to be avallable at optimum pouring temperature when tapped from the furnace.

The possibilities of such savings and increased production make it worthwhile to carefully analyze hot metal handling systems and ladle selections, with the alm of eliminating excessive losses of temperature caused by unnecessary transfers of metal, improper distribution schedules, and inadequate ladle insulation.

In some instances, ladle preheating may be eliminated entirely with the use of 1nsulating fiber ladle 1inings. See Section 2, part $H$ for further discussion.

\section{COKELESS CUPOLA}

A new technology that is creating a great deal of interest is the so called "cokeless" cupola. The basic concept of the cokeless cupola is the replacement of coke as the fuel for melting with a gas or oil fired burner. The charge material is supported by a bed of either refractory spheres or broken refractory products such as bricks. This whole mass rests on a water cooled grate. This concept was originally developed by Taft in England, and further commerclalized by several German cupola manufacturers. Approximately fourteen installations exist in Europe and Canada, ranging in capacity from 2 to 20 tons/hour.

A number of advantages are clalmed over the use of regular cupolas. The use of gas rather than coke eliminates the pick-up of sulfur from the fuel. This is particularly advantageous for the production of ductile iron. Also, the elimination of coke results in less dust and fume that must be collected in order to meet environmental regulations. It is doubtful, however, that pollution control equipment can be completely eliminated as 18 the case in some of the Eastern Bloc countries where the cokeless cupola has been more widely accepted. 
Another consideration is the cost of the refractory bed material. The Taft style of cokeless cupola used refractory spheres that may or may not be carbon coated to provide carbon to the melt. These are gradually consumed (d1ssolved) during the operation and represent a significant cost 1tem. Recent work published by the natural gas industry estimates the cost at $\$ 17.00$ per ton of 1ron produced. Another type of cokeless cupola, developed in West Germany, uses broken brick as the bed materlal which reduces the cost. However, the carbon must be added in a separate operation which offsets some of the savings.

The problem of most concern is the difficulty in achieving a sufficlently high iron temperature to allow further processing. If the burners are operated at a fuel/air ratio that would result in the required temperatures, the furnace atmosphere becomes excessively oxidizing which results in iron quality problems. The usual approach is to use a channel induction holding furnace for temperature adjustment and maintenance.

A pllot sized cokeless cupola was built and operated a number of years ago under the sponsorsh1p of the Gas Research Inst1tute. Work on this unit was discontinued and the results not reported to the industry.

The cokeless cupola has considerable potential for the 1ron foundry, particularly when used in conjunction with a channel induction holder. Further technical and economic evaluations are necessary before the cokeless cupola finds its proper place in the 11st of options avallable to the found ryman. 


\section{COKE AND SUPPLEMENTAL FULLS}

\section{USE IN FOUNDRIES}

Cupolas are coke-fired counterflow heat exchangers for melting Iron. Energy statistics published by the AFS and other organizations show that, on the average, fron foundries using cupolas consume approximately half of their total energy in the cupola. Based on material input to the melting operation, Flgure 2-17 and Table 2-III show energy use in the cupola (National Basis) per net ton of good castings.

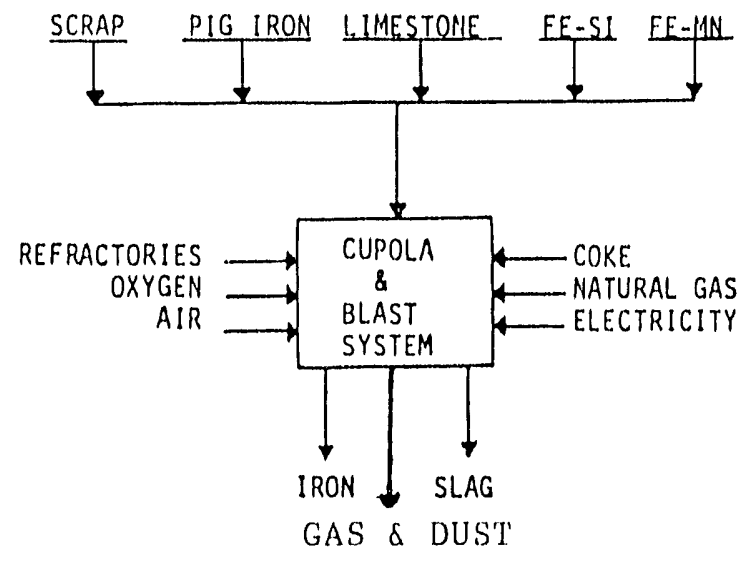

FIGURE 2-13 MATERIALS AND ENERGY USED I CUPOLAS

TABLE 2-III ENERGY USE IN CUPOLA (NATIONAL BASIS)

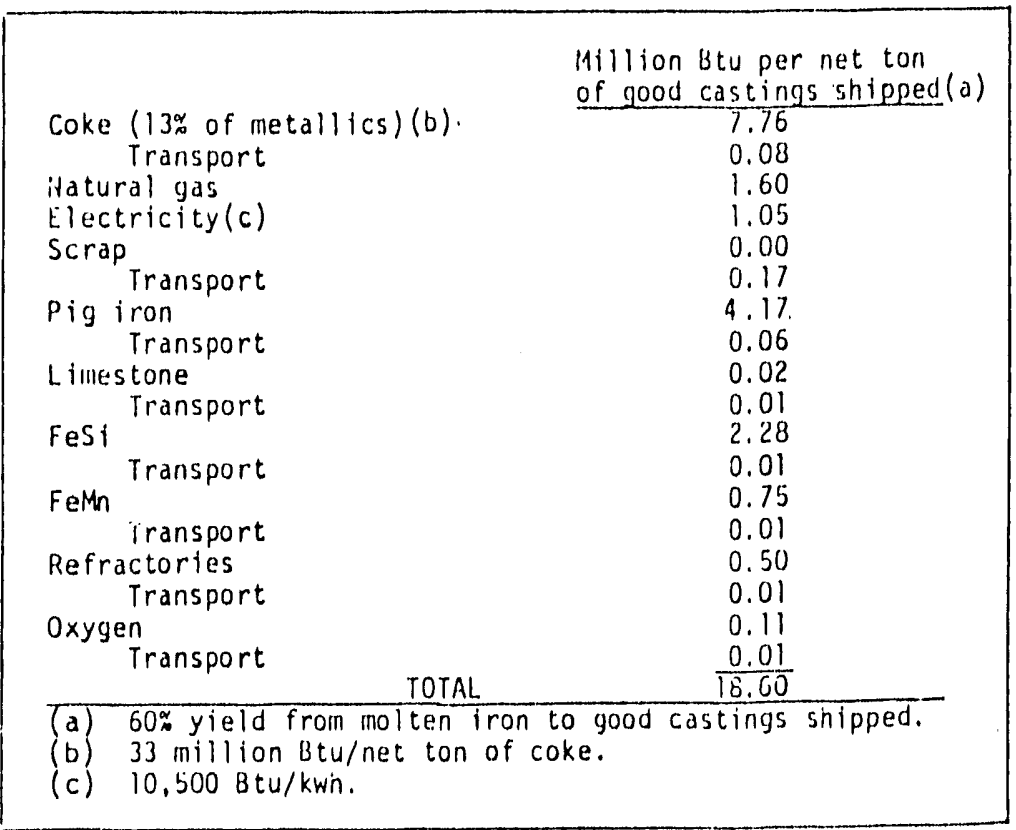


Foundry coke is a solid, cellular residue obtalned when certain bituminous coals are heated, out of contact with air, above temperatures at which active thermal decomposition occurs. Coke formed by heating above $1,652^{\circ} \mathrm{F}$ is called high temperature coke.

Typical foundry coke blends:

TABLE 2-IV. SOME TYPICAL FOUNDRY COKE BLENDS AND COKING CONDITIONS

\begin{tabular}{|c|c|c|c|c|c|c|c|}
\hline \multirow[b]{2}{*}{ Plant } & \multicolumn{3}{|c|}{ Blend, $\%$} & \multirow[b]{2}{*}{ Pulv'nl } & \multirow{2}{*}{$\begin{array}{l}\text { Coking } \\
\text { Time } 2 \\
\text { in./hr }\end{array}$} & \multirow{2}{*}{$\begin{array}{l}\text { Flue } \\
\text { Temp. } \\
\text { Ave. ' } \mathrm{F}\end{array}$} & \multirow{2}{*}{$\begin{array}{l}\text { Coke } \\
\text { Temp. } 3 \\
{ }^{\circ} \mathrm{F}\end{array}$} \\
\hline & $\begin{array}{c}\text { Low Vol. } \\
\text { Coals }\end{array}$ & $\begin{array}{c}\text { High Vol. } \\
\text { Coals }\end{array}$ & Inert 4 & & & & \\
\hline A & 30.5 & 56.5 & 13 & 80 & 1.1 & 2,500 & 1,800 \\
\hline B & 34 & 60 & 6 & 85 & 0.7 & 2,200 & 1,860 \\
\hline C & 32 & 59 & 9 & 80 & 1.1 & 2,610 & 1,800 \\
\hline 0 & 50 & 50 & 0 & 88 & 0.65 & 1,800 & 1,750 \\
\hline$E$ & 38 & 56 & 6 & 90 & 1.1 & 2,300 & -- \\
\hline \multicolumn{8}{|c|}{$\begin{array}{l}\text { Percentage passing } 1 / 8 \text {-in screen. } \\
2 \text { Oven width in inches divided by coking time in hours. } \\
3 \text { Average coke temperature calculated from hydrogen content } \\
\text { (see "Chemical Tests" in this chapter). } \\
4 \text { selected anthracite fines meeting foundry coke size and } \\
\text { gravity specifications. }\end{array}$} \\
\hline
\end{tabular}

\section{SUPPLEMENTARY FUELS}

Anthracte coal 1.s a dense, hard, natural product ranging in fixed carbon content from $85-87 \%$ compared to $90-93 \%$ for coke.

TABLE 2-V. MAJOR MATERIAL PROPERTIES

\begin{tabular}{|l|c|c|}
\hline & Anthracite & Coke \\
\hline Ash & $8-10 \%$ & $6-8 \%$ \\
Volatiles & $4.5-5.5 \%$ & $0.4-0.7 \%$ \\
Sulfur & $0.4-0.65 \%$ & $0.60-0.70 \%$ \\
Heat content (Btu/lb) $3,00-13,900$ & $12,500-13,500$ \\
Material density lbs/ft & $53-58$ & $26-32$ \\
\hline
\end{tabular}

The greater density gives more energy per volume of space occupied by the coal in the cupola; however, the nonporous nature causes slower burning .

Usage of anthracite coal up to $25 \%$ of the total fuel has been reported with some modification necessary to cupola operation and careful control of material size.

If oxygen enrichment is also avallable, the use of greater than $25 \%$ coal may be feastble. 
It is comon practice at many foundries to store coke in the open. No appreciable deterioration results in inild weather, but when exposed to alternate freezing and thawing, the size can be degraded due to water freezing in the coke fissures. Also, molsture content of coke increases if not stored under cover resulting in increased energy usage to dry the coke charged in the cupola.

\section{OTHER FUELS}

Supplementary cupola charge fuels are in use. Coke breeze is used as briquettes or direct injection through the tuyeres.

Table 2-VI shows typical analysis and sizing of the infection grade coke fines being used in a typical injection system. The substitution of injected coke fines for charge coke has resulted in reduction of charge coke by as much as $20 \%$. Replacement ratios of coke removed versus fines injected range from $1: 1$ and $1.5: 1$, that is to say, more coke is removed than fines infected with the corresponding cost reduction for materials.

TABLE 2-VI. COKE FINES SPECIFICATIONS

\begin{tabular}{|c|c|c|}
\hline SIZING: & 10 MESH $\times 0$ & \\
\hline \multirow[t]{5}{*}{ PROXIMATE ANALYSIS: } & Fixed Carbon & $88.0 \%$ \\
\hline & Ash & $11.0 \%$ \\
\hline & Volatile & $1.0 \%$ \\
\hline & Sulfur & $0.60 \%$ \\
\hline & Mois ture & $-1.0 x$ \\
\hline
\end{tabular}

TABLE 2-VII. COKE SUBSTITUTION VALUES FOR THREE CUPOLA OPERATIONS USING COKE FINES TUYERE INJECTION

\begin{tabular}{|c|c|c|c|c|c|c|c|c|c|}
\hline CUPOLA & $\begin{array}{r}\text { CUPOLA } \\
\text { DIALIETER }\end{array}$ & $\begin{array}{l}\text { BLAST } \\
\text { TEMAP } \\
{ }^{\circ} \mathrm{F}\end{array}$ & $\begin{array}{l}\text { OXYGEN } \\
\text { ENRICHMENT }\end{array}$ & $\begin{array}{l}\text { SCFM } \\
\text { BLAST } \\
\text { RATE } \\
\times 1,000\end{array}$ & $\begin{array}{l}\text { MELT RATE } \\
\text { TONS/HOUR }\end{array}$ & $\begin{array}{l}\% \text { COKE } \\
\text { CHARGEO }\end{array}$ & $\begin{array}{l}\text { * SUBSTITUTION } \\
\text { OF CHARGED COKE }\end{array}$ & \multicolumn{2}{|c|}{$\begin{array}{l}\text { SUBSTITUTION RATIO } \\
\text { POUND(S) OF COKE } \\
\text { REMOVED TO EACH } \\
\text { POUND OF COKE } \\
\text { FINES INJECTED }\end{array}$} \\
\hline A & $122^{\prime \prime}$ & 1.200 & $2 \%$ & $25-27$ & $50-60$ & $12 \%$ & $13 \%$ & 1.3 & 1 \\
\hline B & $108 "$ & 950 & INTERMITTENT & 18 & 35 & $15.8 \%$ & $11.4 \%$ & 1.6 & 1 \\
\hline c & 46 & NO & YES & & 10 & $19.5 \%$ & $10.3 \%$ & 1.25 & 1 \\
\hline
\end{tabular}




\section{CUPOLA MODIFICATIONS}

Hot Blast and Divided Blast Cupolas. The application of the preheated alr blast (hot blast) has lmproved the combustion efficlency and flextbility of cupola operations. Eng ineering developments have produced gas flred external heater systems capable of $1000-1200^{\circ} \mathrm{F}$ blast. Most modern Installations incorporate recuperative heating into the design in order to ut1lize the combustion potential of the off-gas. The hot blast. accelerates the combustion reactions and can increase temperature and carbon pick-up thus permitting the use of a higher percentage of steel scrap in the charge, or it can increase melt rate with a lower coke consumption.

Divided blast cupolas utilize a second row of tuyeres to proportionally distribute the combustion alr between two levels to obtain increased combustion efficlency and reduced coke consumption.

Oxygen Enrichment

The use of oxygen for cupola melting has been successful on both a continuous and intermittent basis. The amount of oxygen added is usually from 1 to $4 \%$. The application of oxygen enrlchment results in increased melt rate, higher temperature and increased flextbility. 


\section{WASTE HEAT RECOVERY SYSTEMS}

\section{GENERAL CONSIDERATIONS}

The first step in heat recovery analysis to to survey the l'oundry and take readings of all recoverable energy that lo being discharged to atmosphere. The survey should include analysts of the following condltlons:

\section{- Exhaust stack temperatures}

- Hlow rates through equipment

- Particulates, corrosives of condenstble vapors tin the alr stream

Ventilation, process exhaust and combustion equipment exhauste are the mafor sources of recoverable energy.

Table 2-VIII Lllustrates typlcal energy savings achleved by preheating combustion afr with hot exhaust gases from process or furnaces.

TABLE 2-VIII. FUEL SAVINGS REALIZED BY PREHEATING COMBUS'LION AIR*

Fuel savings, percent, when combustion alr prehedt temporature, $F$, is:

\begin{tabular}{|c|c|c|c|c|c|c|c|c|c|c|c|}
\hline $\begin{array}{l}\text { Furnace } \\
\text { outlet } \\
\text { eemperature, f }\end{array}$ & 400 & 500 & 600 & 700 & 800 & 900 & 1000 & 1100 & 1200 & 1500 & $1^{\prime \prime} 0$ \\
\hline 2600 & 22 & 26 & 30 & 34 & 37 & 40 & 43 & 46 & 18 & 50 & 52 \\
\hline 2500 & 20 & 24 & 28 & 32 & 35 & 38 & 41 & 43 & 15 & 48 & 50 \\
\hline 2400 & 18 & 22 & 26 & 30 & 33 & 36 & 38 & 11 & 43 & 45 & 4) \\
\hline 2300 & 17 & 21 & 24 & 28 & 31 & 34 & 36 & 39 & 11 & 43 & 45 \\
\hline 2200 & 16 & 20 & 23 & 26 & 29 & 32 & 34 & 37 & 39 & 11 & 43 \\
\hline 2100 & 15 & 18 & 22 & 25 & 28 & 30 & 33 & 35 & 31 & 39 & 41 \\
\hline 2000 & 14 & 17 & 20 & 23 & 26 & 29 & 31 & 33 & 36 & 38 & 40 \\
\hline 1900 & 13 & 16 & 19 & 22 & 25 & 27 & 30 & $3 ?$ & 34 & 16 & 38 \\
\hline 1800 & 13 & 16 & 19 & 21 & 24 & 26 & 29 & 31 & 33 & 35 & 37 \\
\hline 1700 & 12 & 15 & 18 & 20 & 23 & 25 & 21 & 30 & 32 & 31. & 35 \\
\hline 1600 & 11 & 14 & 17 & 19 & 22 & 24 & 26 & 28 & 30 & 32 & 34 \\
\hline 1500 & 11 & 14 & 16 & 19 & 21 & 23 & 25 & 27 & 29 & 31 & 33 \\
\hline 1400 & 10 & 13 & 16 & 18 & 20 & 22 & 25 & 27 & 28 & 30 & m. \\
\hline
\end{tabular}

* Natural gas with 10 percent excess alr: other charts are

avallable for different fuels and varlous amounts of excess alr. 
Regardleas of the amount or temperature of the energy diwoharged, reoovery 1. impraotloal unias. the heat oan be effectively umed ol wewhere in the foundry. Alwo, the reoovered heat must be cratiable when it is neaded, if not, mome mort of hat utorage equlpment is nocousary whioh will inorease the capltal oost expenditure and minlmize the return on investment.

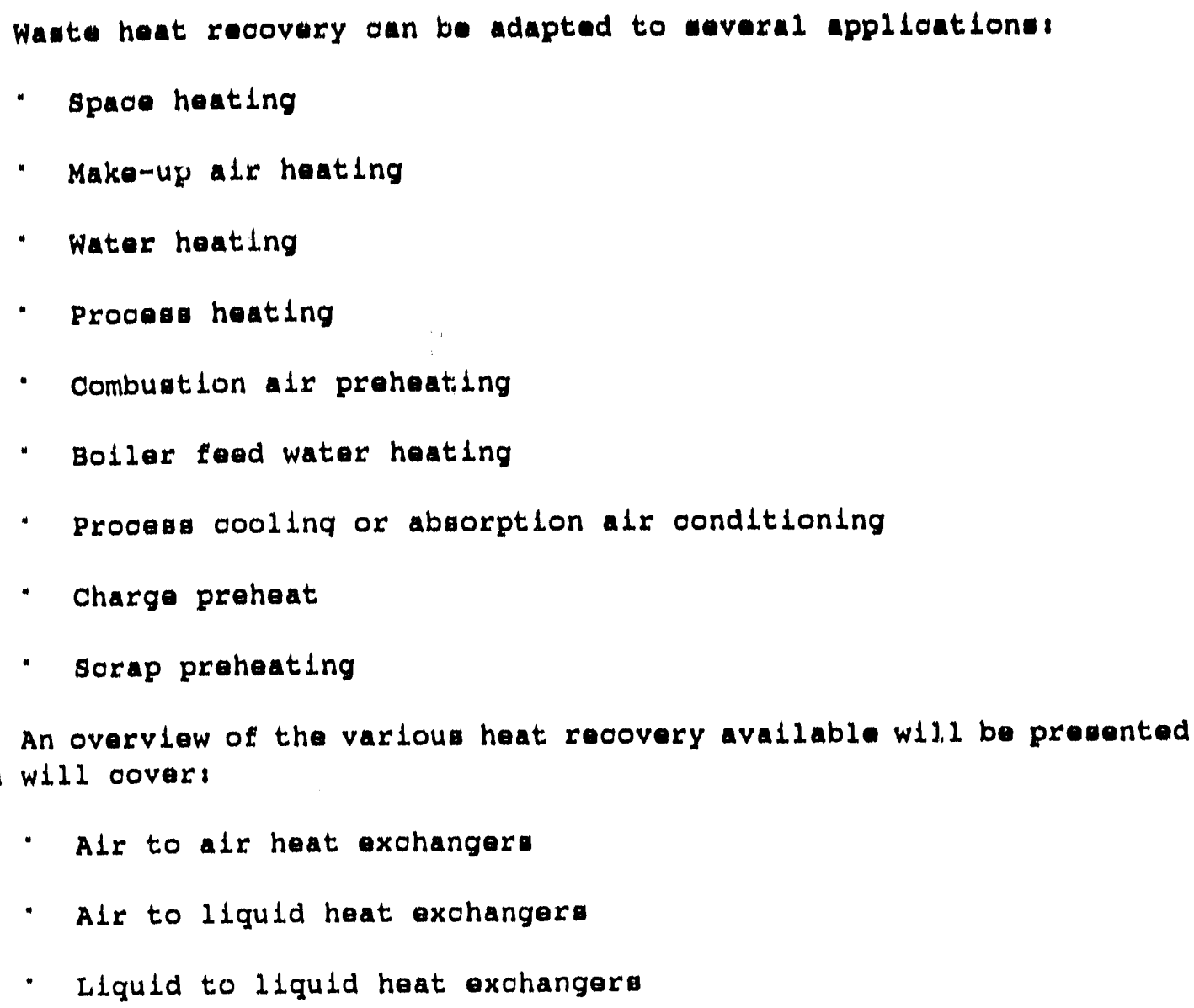

An overviow of the varlous heat recovery avaliable wll.1 be presented

- Alr to alr heat exchangera

- Air to liquid heat exohangera

- Liquid to Ilquid heat exahangers which will cover:

\section{TYPES OF HEAT RECOVERY EQUIPMENT}

Choosing the type of heat recovery device for a particular applioation dependa on a number of factors. For example alr-to-air aquipment i. the moat practioal oholoe if the polnt of recovery and uae are close coupled. Alr-to-liquid equipment ia the logloal choloe if longer distances are involved.

This atudy addresses five types of heat recovery equipment:

- Boonomizers

- Heat plpes

- Shell and tube heat exchangers

" Regenerative unito 


\section{Meonomizers}

Eoonomizers are alr-to-1 qquld exchangers. Thele primary applioation 1. to preheat boller feed water. They may aloo be uaed to heat prode日a or domeatlo water, or to provide hot liquida for apace heating or make-up air heating equipment.

The balo operation is a followe: Sendble heat la trangferred from the flue gaser to the dearated feed water, as the liquid flowe through a serles of tubes in the economizer, which lo looated in the exhaust ataok.

Most economizers have finned tube heat exchanges constructed of atalniess ateel whlle the lnlet and outlet duate are oarbon ateel lined with altable ingulation. Maximum reoommended waste gas temperaturea for atandard unita 1 g $1,800^{\circ} \mathrm{F}$.

Acoording to economlzer manufacturers, fuel consumption la reduced approximately is for each $40^{\circ} \mathrm{F}$ reduction in flue gas temperature. The higher the flue gas temperature the greater potentlal for enorgy aringa.

\section{Heat: PLpen}

The heat plpe thermal reoovery unit il a oounter flow alr-to-air heat exchanger. (See Figure 2-14)

Hot air la passed through one side of the heat exohanger and cold alr la passed through the other alde in the opposite direotion. 

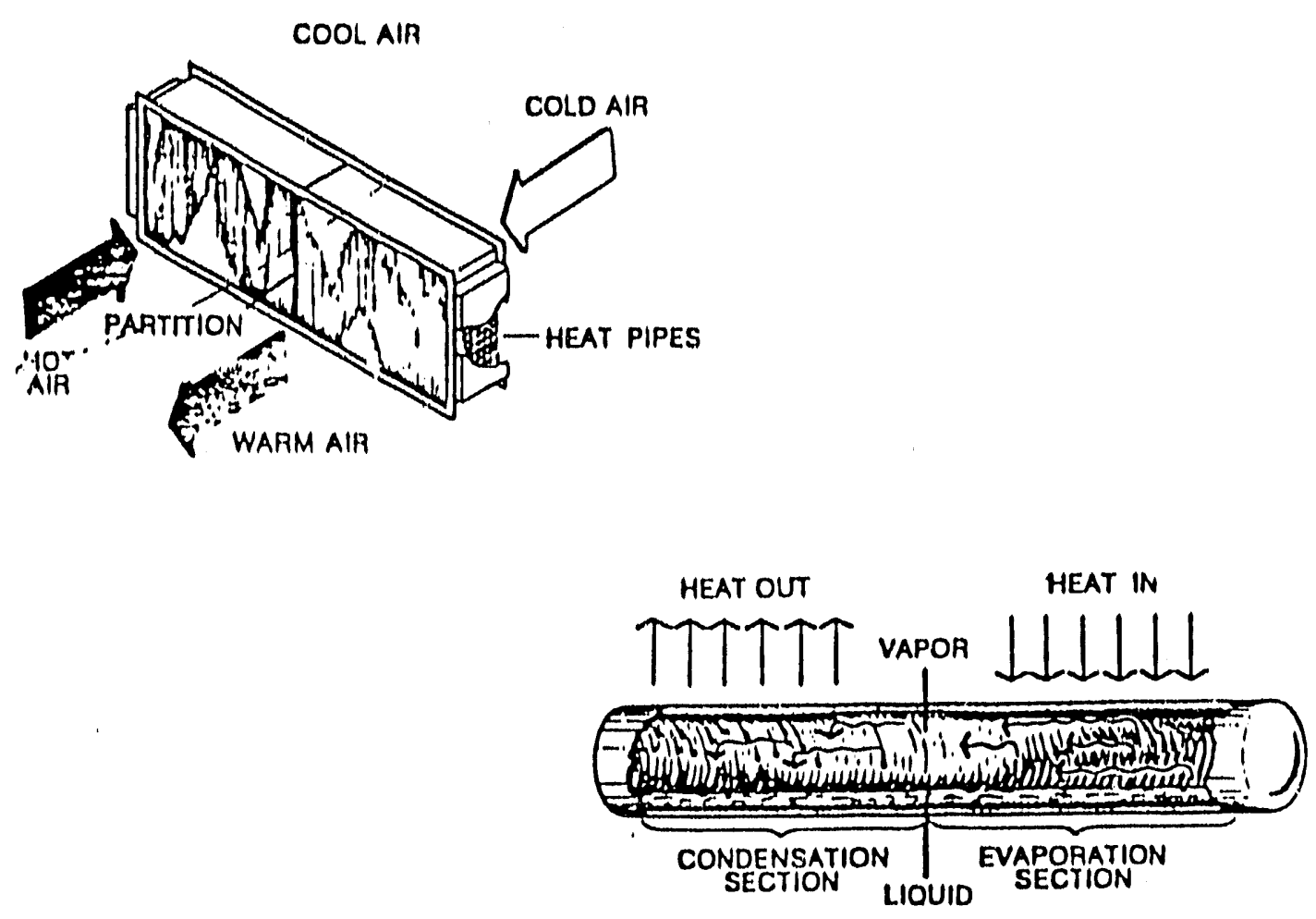

FIGURE 2-14. TYPICAL HEAT PIPE CONFIGURATION

Heat plpes are usually applied to process equipment in which discharge temperatures are between $150^{\circ}$ and $850^{\circ} \mathrm{F}$. There are three general classes of application for heat pipes:

(a) Recycling heat from a process back into a process (process-to-process)

(b) Recycling heat from a process for comfort and make-up air heating (process-to-comfort)

(c) Condtioning make-up atr to a bullding (comfort-tocomfort)

Heat plpes recover between 60 to $80 \%$ of the sensible heat between the two alr streams. A wide range of sizes are avallable, capable of handling 500 to 20,000 cu $f t$ of air per minute. The main advantages of the heat plpe are:

- No cross contamination

- Operates without external power

- Operates without moving parts

- Occuples a minimum of space 


\section{Shell and Tube Heat Exchangers}

Sheil and tube heat exchangers are liquid-to-liquid heat transfer devices. Their primary application is to preheat domestic water for toilets and showers or to provide heated water for space heating or process purposes.

The shell and tube heat exchanger is usually applied to a furnace process cooling water system, and is capable of producing hot watar approaching $5^{\circ}$ to $10^{\circ} \mathrm{F}$ of the water temperature off the furnace.

To determine the heat transfer capacity of the heat exchanger the following conditions of the operation must be known:

- The amount of water to be heated in gallons per hour

- The amount of hot process water available in gallons per hour

- Inlet water temperature and final water temperature desired

- Inlet process water temperature

Regenerative Unit (Heat wheel)

The heat wheel is a rotary air-to-air energy exchanger which is installed between the exhaust and supply air duct work in a make-up or air heating system. It recovers 70 to 908 of the total heat from the exhaust air stream.

Glass fiber ceramic heat recovery wheels can be utilized for preheating combustion air with exhaust flue gases as high as $2,000^{\circ} \mathrm{F}$. 
Heat wheels consist of: rotating wheel, drive mechanism, partitions, frames, air seals and purge section. Regeneration is continuous as energy is picked up by the wheel in the hot section, stored and transferred to the colder air in the supply section as the wheel rotates through it.

\section{Recuperatorg}

Recuperators are air-to-air heat exchangers built to provide efficient transfer of heat from hot exhaust gases to a cooler air stream.

Recuperators are generally used in the following processes:

- Preheating combustion air

- Preheating scrap metal

- Provide hot blast at cupola's

- Recovery heat from hot gas to supplement or replace the primary heat source in process or comfort heating applications. 
There are many different types of recuperator designs avallable torlay. The recuperator 11lustrated in Figure 2-15 is primarily used for combustion air preheating. It consists of three basic cylinders, the hot gases flow up through the inner cylinder, cold combustion air enters at the bottom of the outer cylinder, flows upward and down through the middle cylinder, exiting from the bottom of the middle cylinder.

Heat energy from exhaust gases is transferred through the inner cylinder wall to the combustion air by a combination of conduction and radiation heat transfer. The net effect is preheated air temperatures as high as $1,000^{\circ} \mathrm{F}$ with inlet exhaust gases entering at $2,000^{\circ} \mathrm{F}$ and exiting at $1,300^{\circ} \mathrm{F}$.

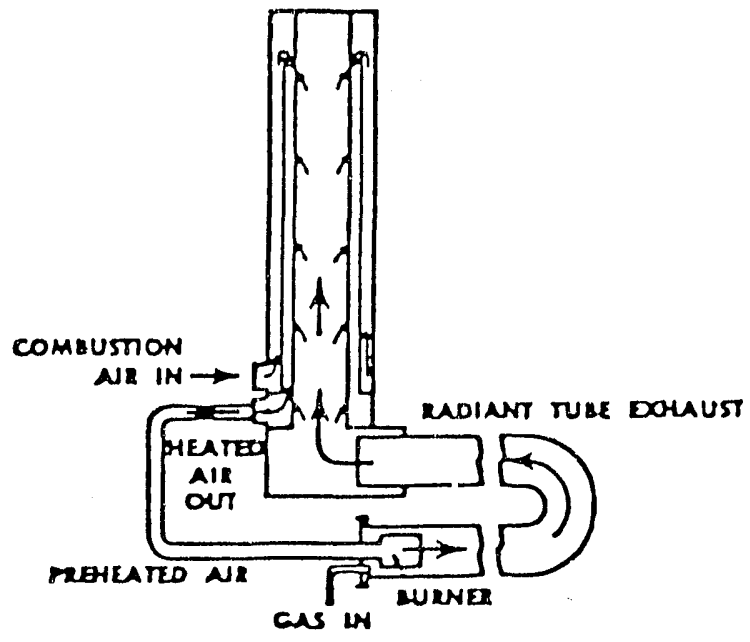

FIGURE 2-15. OPERATING PRINCIPLE

OF RECUPERATOR 


\section{E. PROCESSES OF SECONDARY IMPORTANCE}

As previously stated, approximately 208 of the plants energy input is consumed in secondary procesges - no attempt has been made to quantify energy savings in these areas except where actual percentages can be quoted from other sources.

\section{CLEANING AND FINISHING}

Material handling, welding, grinding, inspection, and painting processes comprise the minor energy using activitien remaining after heat treatment. Areas where additional energy can be conserved:

1. Compressed air tools and hoists require frequent servicing to maintain efficiency. Adequate lubrication is essentlal to reduce friction in high velocity air motors.

2. Air hoses should be sized for minimum pressure drop to air tools, a 108 drop from designed supply air pressure of $90 \mathrm{pol}$ results in 15 reduction in production output.

3. Replace air driven equipment with induction motors where practical. A high apeed induction motor can produce $5 \mathrm{cfm}$ at 100 psi pressure; an equivalent vane type air motor would consume $25 \mathrm{cfm}$ at the same pressure requirement.

4. Check and replace worn sand blast air nozzles to reduce air consumption. 5/16" nozzle worn to $3 / 8$ " diameter will consume an additional 55 to $70 \mathrm{cfm}$.

5. Welding units of the motor generator type should be shut down when not in use. Smoke detector activated exhaust fans over welding area will reduce unnecessary $108 s$ of in-plant heated air and power consumption. When using coated electrode-metal arc welding, use the largest diameter electrode possible to improve efficiency.

\section{EXAMPLE}

\begin{tabular}{|c|c|c|c|c|}
\hline Rod size & Current & $\mathrm{kW}$ & Deposition & $\frac{\text { Welded }}{\text { Efflciency }}$ \\
\hline $1 / 8 "$ & $110 a$. & 5.6 & $0.87 * / \mathrm{hr}$. & $47 \%$ \\
\hline $3 / 16^{\prime \prime}$ & $150 a$. & 7.65 & $1.32 * / \mathrm{hr}$. & 518 \\
\hline $1 / 4^{n}$ & $250 \mathrm{a}$. & 13.65 & $2.50 \% / \mathrm{hr}$. & $55 \%$ \\
\hline
\end{tabular}

6. Paint lines should use airless spray guns. It requires 9.5 HP to atomize $1 \mathrm{gpm}$ using air spray, compared to approximately 1.3 HP for airless type.

7. Consider direct fired paint drying ovens instead of indirect. The heat transfer coefficient for direct fired is about 978 v日. 608 for indirect. 
8. Install insulation on paint line heated wash and pretreatment tanks. For instance, an uningulated vessel at $200^{\circ}$ can waste up to $315 \mathrm{BTU} / \mathrm{hr} / \mathrm{sq}$. ft. Investigate using recovered process heat as source for paint line heating requirements. Schedule paint line for continuous perlod of operating rather than frequent shut downs and staxt ups. Robot painting manipulators can be programmed to start and stop the cycle as required.

9. Fork truck idling time and use of oversize vehicle for job wastes energy. Install door opening and olosing devices operable by truck driver in the operating geat. If possible, install double air-lock doors. In large facilities use portable radios to direct fork trucks to next asilgned area to reduce empty trips.

10. Improve work flow to reduce handling and movement.

MOLD AND CORE MAKING

The following modifications, changes, and additions to mold and core making operations to effect energy saviugs are:

1. Install manual shut-off valves on each gas distributing line on shell core making machines.

Example: A foundry in the midwest installed valves to control the flow of gas to each row of burner tips. Their objective was to use only as many gas tips as were required to heat the core box. By cutting of $f$ one row of burner tips, their energy savings amounts to $256 \times 10^{6}$ Btu per year.

2. Convert from hot box phenolic resin cores to cold box cores.

The same foundry as in (1) above saved gas in the amount of $1.170 \mathrm{Btu}$ per pound of core or $675 \times 10^{6} \mathrm{Btu}$ per year. In addition, they produced the cold box cores about three times as fast as the bottom box cores.

\section{POURING AND SHAKEOUT}

The following modifications, changes and additions to pouring and shakeout operations to effect energy savings are:

1. Excessive lighting levels over areas of mold cooling and incandescent lights used at work stations can be changed to reduce energy. Reported improvements of up to $15 \%$ were obtained by switching to high-pressure sodium lighting at a New Haven foundry. 
2. Movement of clean waste heat to where it is needed can be profitable by recovery of heat from molds and cooling areas for process heat in other areas.

3. Pouring yleld, that ia, the effective weight of castinga per mold relative to gross metal poured into the mold, is an important statiotio indicating efficiency of pattern layout and gating techniqueg.

An improvement in pouring yield from 408 to 458 reduced energy in remelting the returns approximately 98 at Hayes Albion and even at 608 yleld, about 408 of melt energy 1 s still being dissipated by recycling of metal within the foundry. Yleld improvement will be discussed further in section 2, Part $G$.

4. Shakeout systems operating with no load and excersive sand to metal ratiog consume energy with no increase in production.

\section{COMPRESSED AIR SYSTEMS}

A number of simple guidelines, if effectively followed, can save foundries significant amounts of energy through conservation of compressed air.

Conservation measures are especially nireded to increase the efficiency of pneumatic cylinders. Some foundriss have oversized cylinders and longer than necessary strokes. Only one cylinder size is correct for any given application and knowledgeable suppliers can provide the information necessary to determine the correct cylinder for any specific operation.

Use of higher pressure than those required wastes considerable compressed air; limiting pressures to the desired level with quality regulators quickly repays the initial investment. Figure 2-16 shows effect of different line pressurea. 


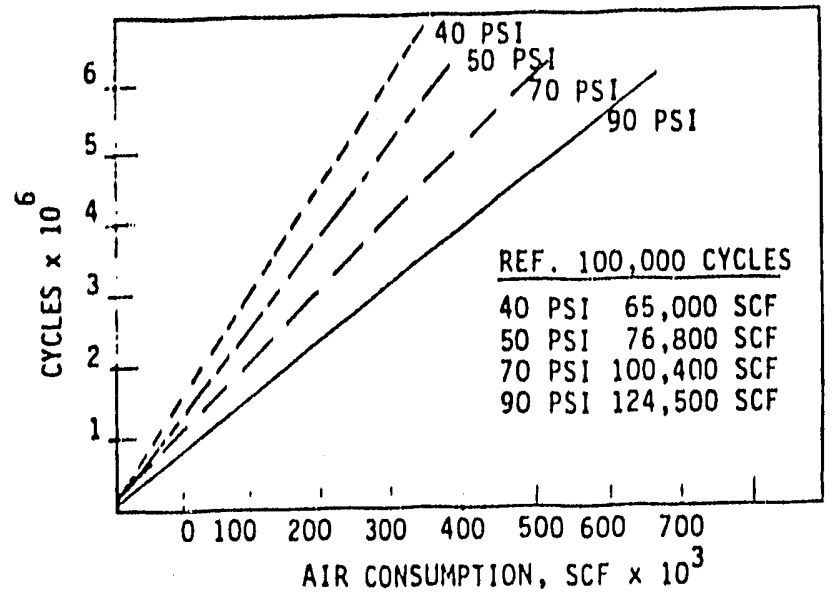

FIGURE 2-16. HOW LINE PRESSURE AFFECTS AIR CONSUMPTION

A large percent of cylinder and rotary actuator applications require maximum thrust in one direction only and the return stoke can be made with greatly reduced pressure - this is true with jolting, squeezing, stamping, swaging, clamping, and cutting operations -- see Figure 2-17.

WITHOUT REGULATOR

Advance stroke ................... 90 psi

Retract stroke ..................99 psi

Air consumed ............... $156 \mathrm{cu} . \mathrm{in} . / \mathrm{cycle}$

WITH REGULATOR

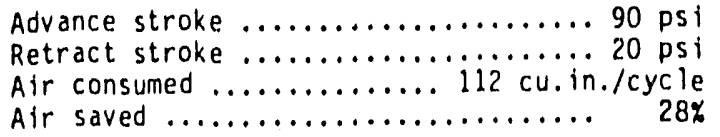

FIGURE 2-17. HOW PRESSURE REGULATION SAVES ENERGY

\section{Air Leaks}

Leaks occur from defective hoses, couplings, fittings, valves, tubes, and actuators. Even leaks that cannot be detected audibly contribute to substantial energy losses. The cost of energy loss through misapplication and leakage in pneumatic systems is so appreciable that it often results in foundries purchasing unnecessary air compressor capacity. Unnecessary expenditures combined with wasted air can be curbed with effective energy management.

Example of $10 \mathrm{ss}$ in energy due to leaks:

- 1/16 inch diameter a1r. leak uses about $2,520 \mathrm{kwh} /$ year

- $1 / 8$ Inch diameter afr leak uses about $10,100 \mathrm{kwh} / \mathrm{year}$ 
Duat collection equipment (baghouses, scrubbers, eto.) and 1ta aspoclated exhaust fans and miscellaneous accessories consume relatively large amounts of electricity.

Foundries generate a lot of dust and fumes in many phases of production. In order to satiafy the Environmental protection Agency (EPA) and local afr pollution control agencies, large volumes of alr need to be exhausted. Often, exhaust air must be replaced with pre-heated make-up alr, adding to overall energy consumption.

The energy aavings potential for duat of fume collection equipment is minimal providing the system is operated and maintained correctly. The following checkliat ahould be implemented to minimize electrical power consumption.

1. Ingtall. well deaigned ventilation hoods to keep alr volume to a minimum.

2. Keep pregsure drops acrose filters within initial design parameters.

3. Develop and maintain strict preventative maintenance procedures. (Check for leaks and infiltration.)

4. Turn gystem off when not needed.

Recent work indicates that the use of Adjustable Speed Drives (ASD) can provide aignificant energy savings over motors operated at constant speed.

\section{HEATING, VENTILATION, AND AIR CONDITIONING}

The need for comfort heating, ventilation and air conditioning can be significant in some areas for offices, pattern shops, laboratories, and the like.

Invertment casting facilities generally have fairly large proces air conditioning systems with otringent humidity requirements. Interior design conditions are usually $72^{\circ} \mathrm{F}$ dry bulb temperature and $45^{\circ}$ relative humidity which requires both uummer dehumidification and winter humidification.

Due to the many types of syatem variations and equipment applications in investment casting facilities it is impossible, and beyond the scope of this otudy, to recommend energy conservation measurea in speciflc terms. Facilities with air conditioning systems larger than 20 tons $(240,000 \mathrm{Btu} / \mathrm{hr})$ should engage qualified professionals to optimize system performance. 
The following list points out some areas where energy could be conserved olther by retrofit, ohanges and/or modificatione to exiating aystems:

- Add additional insulation to roofs, cellings, or walla where practical.

- Install solar film on windows to out cooling loads.

- Install weather stripping around windows and doors.

- Install higher efflolency lighting aystems where posaiblo.

- Recalibrate all controls.

- Lock thermostat to prevent resetting by unauthorized personnel.

- Install enthalpy controls to optimize use of outside air for natural cooling.

- Retest, balance and adjust eystems.

- Turn off air conditioning machinery during unoccupled hours.

- Optimize system startup times.

- Reduce outdoor air and system air volumes.

- Replace forced air heaters with infrared heaters.

- Insulate piping and ductwork in unconditioned spaces.

- Reclaim process exhaust energy and utilize it for space heating and absorption cooling.

- Install solar-assisted heat pumps.

- Replace constant volume air systems with variable volume type.

- Uae proper water treatment to reduce fouling of heat transfer surfaces in chillers and heat exchangers.

- Maintain all equipment for peak efficiency.

- storm doors and windows.

\section{PROCESS WATER}

Some foundries utilize "once through" process cooling water systems for melt furnace and quenching operations.

Water recovery in the foundry is a valuable source of increasing operating economics, and can lend itself to energy recycling. Cooling for 
hydraulio presses, alr compressors, melting furnaces, and quenohing operation ia generally acoomplished with water. As much as 988 of otherwise wasted water can be recbvered by lnatalling a "olosed loop" recirculating water system. The evaporative cooler, commonly referred to as a cooling tower is normally used for this purpose.

\section{PLANT LIGHTING SYSTEMS}

Foundries utilizing incandescent lighting syatems can save signifloant amounts of energy by replacing existing unite with high preseure sodium units. For examples If a foundry replaced 365 - 1,000 watts incandescent units with 185 - 400 watt high pressure sodium unito (HPS) the resulting decrease in electrical load would be 288 kllowatta with no slgniflcant change in light level. Aseuming the lights burned 250 days per year, and 8 hours per day and the cost of electricity was 5 cents per XWH the energy cost savings would amount to:

$$
288 \mathrm{~kW} \times 250 \times 8 \times 0.05=\$ 28,800 \text { per year. }
$$

In addition to conserving electrical energy, further saving oan be realized in replacement costa due to the longer ilfe of the HPS syatem. 
PART F

LONG TERM PROCESS CHANGES

\section{CHARGE PREHEATING}

Preheating of charge material is considered to be cost-efliective, however, total use of energy may increase.

Overall energy reduction would be possible with gas preheating provided that waste heat is recovered for combustion air heating.

The percent heat distribution in melting 1ron from $70^{\circ} \mathrm{F}$ temperature to $2,700^{\circ}$ is as follows:

\begin{tabular}{|c|c|c|c|c|c|}
\hline Form & Temperature & $\begin{array}{l}\text { Sp, heat } \\
\text { Btu/lb./ }{ }^{\circ} \mathrm{F}\end{array}$ & $\begin{array}{l}\text { Heat } \\
\text { Content } \\
\text { Btu/1b. }\end{array}$ & $\begin{array}{c}\text { Percent } \\
\text { Heat } \\
\text { Requitred }\end{array}$ & Stage \\
\hline $\begin{array}{l}\text { Solid } \\
\text { Solid } \\
\text { Solid } \\
\text { Solid } \\
\text { Liquid } \\
\text { Liquid } \\
\text { Liquid }\end{array}$ & $\begin{array}{rr}70^{\circ} & F \\
1,000^{\circ} & F \\
1,200^{\circ} & F \\
2,300^{\circ} & F \\
2,300^{\circ} & F \\
2,600^{\circ} & F \\
2,700^{\circ} & F\end{array}$ & $\begin{array}{l}0.130 \\
0.140 \\
0.147 \\
0.161 \\
0.214 \\
0.209 \\
0.208\end{array}$ & $\left.\begin{array}{r}10 \\
140 \\
176 \\
370 \\
492 \\
543 \\
562\end{array}\right\}$ & $\begin{array}{l}65 \% \\
22 \% \\
\frac{13 \%}{100 x}\end{array}$ & $\begin{array}{l}\text { Prehedt } \\
\text { Melt } \\
\text { Superheat }\end{array}$ \\
\hline
\end{tabular}

FIGURE 2-18. THERMAL PROPERTIES OF IRON

The percent heat required column indicates that mafor energy is used to preheat the metal.

The methodology used for comparing gas preheating versus all electric melting to as follows:

Heat required for preheating is expressed as

Btu/1bs. of metal = $\left(t_{1}-t_{2}\right) \times$ specific heat

Where :

$t_{1}=$ final preheat temperature $\left(1,000^{\circ} \mathrm{F}\right)$

$t_{2}=$ Inftial cold temperature $\left(70^{\circ} \mathrm{F}\right)$

Specific heat of iron $(0.140)$

Therefore: Heat required to ralse to $1,000^{\circ} \mathrm{F}$ 1s:

$$
(1,000-70) \times 0.140=135.8 \mathrm{Btu} / 1 \mathrm{~b} .
$$


Cogeneration, in simpliatlc terms, in a process of "energy cascadIng" by utilization of watte heat from vartous foundry operations (1.e., heat treat furnaces, melt furnaces, etc.).

The flrgt atep (or top cycle) of a cogeneration syatem 18 the generation of electrictty which la uead for in-plant electrlcal base load or peaking load service. The electrlctty produced replaces, in part, that which lo normally purchased from the utility company. The last step (bottom cycle) In the thermodynamic cycle 18 the use of wate steam for Industrlal processes and/or environmental conditioning (aec Figure 2-19 below).

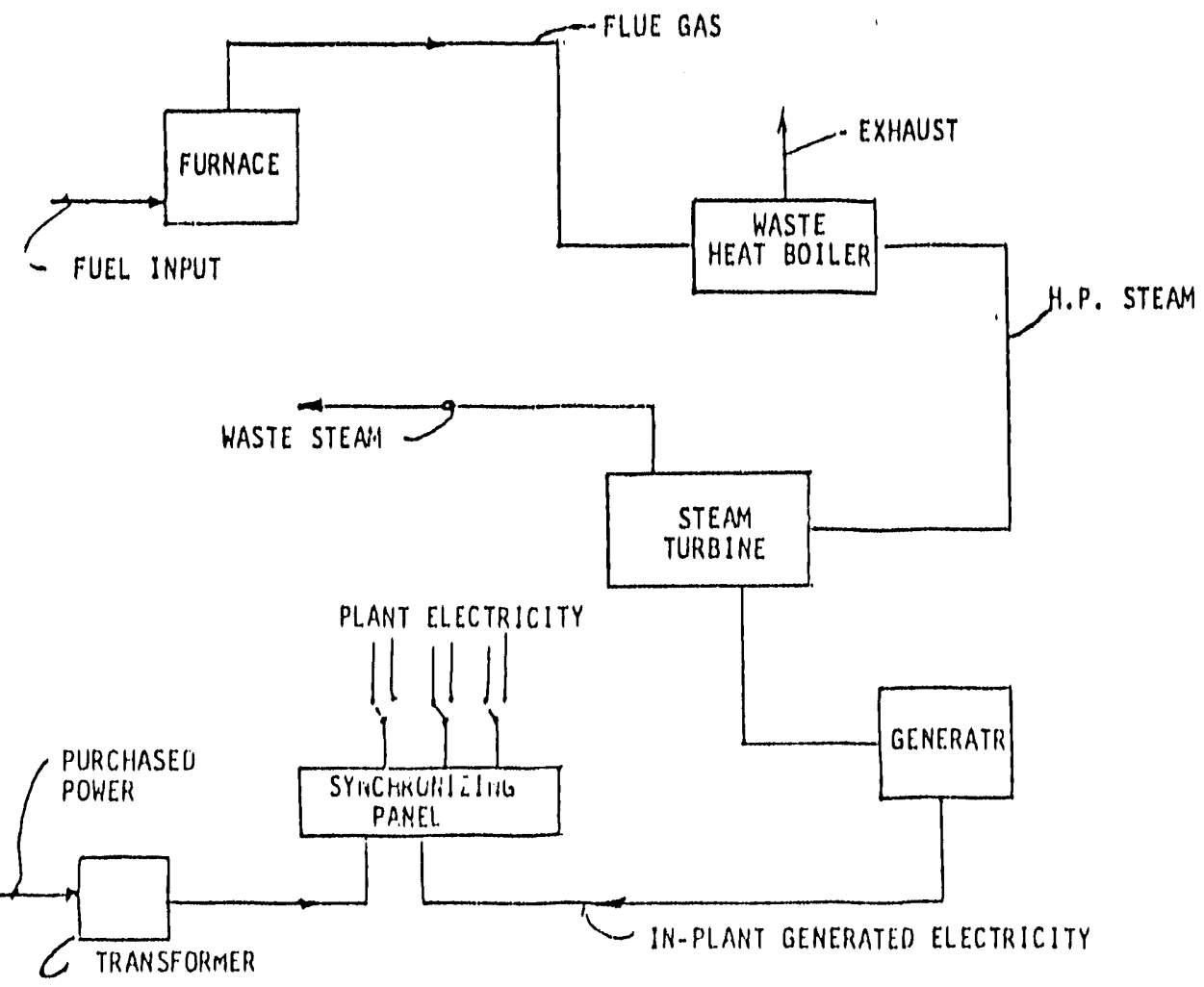

FIGURE 2-19. COGENERATION BLOCK DIAGRAM

Cogeneration in a typlcal foundry is an intermittent operation, electricity production is possible only when equipment that is developing waste heat 18 operational. 
Raterring to oogeneration blook diagram, Flgure 2-19, the following major aquipment is requirad for on-ulte power generations

- Wante hoat reoovery bollerl those are avaliable in water tube or ilse tube dentign.

- stoam turbina

- Eleotrloal generator

- Automatio mynchronization equipment

caneration of on-alte power by utilization of plant waste heat io axtremely cootiy to inatall and maintaln. Alwo, goneration of high proseure wteam could posibly rogulre a full-time clase "A" bollar oparatox.

The complexity and Initial expense of cogenexation, when applled to the typloal foundry, is not oost-effective at thid time. A detalled and comprehenelve analyals would be required to fuatify the use of on-alte power goneration in foundry of sultable olze to warrant suoh a gytem. 
PART C

MANAGEMENT ACTIONS

\section{YIMILD TMPROVEMFNT PROGRAMS}

Improvement in mold yield, to Inoraase good oastingw relative to total poured motal, has a direot impact on onergy usage by reduotion of total melted motal required for a flxed welght of good oastings.

Yield 1. made up of weveral part comprialng the effectu of:

- Melt 10ag due to oxidation

- slag

- splil motal

- Plgged metal

- Pouring gystem, (gating, rlserd, excoss oasting waight)

- Sorap loses, grinding and maohining 108008

The typloal foundry overall yleld is 508 whioh results in required energy to melt double the finlohed casting weight. One percent yleld Improvement for 100-pound casting, from 508 to 518 , reduces metal melted by 4 pounda. (Yleld varies with metal melted and processes used.)

Melt Lo88e日:

ocour in all molting processes and range from 128 in electrio furnaces to 7-108 in oupolas or higher in direot gas-fired furnaces. Selection of raw materials and raderlgn of melting unit and method changes can minimize the 1088.

Slag:

Generated from lmpurities in the metal and oxidation, inoluder a percentage of pure metal, operating practices to restriot excess metal entrapment in the olag are necessary.

spill:

Inaccurate pouring and poor transfer techniques result in metal meited that is not avallable for casting.

Pigged Metal: Can amount to 1-28 of total metal melted. The correct measurement of ladle quantities ia necessary in order to avold skull s remalning after pouring. Correct alzing of ladles to prevent exceeding the workable pouring temperature range, before all the metal lo utilized, will reduce pigging lose日. 
Pouring Systems: Ratio of poured metal to gross castings is the base yield figure. Improvements to runner systems, small risers or exothermic/insulators on the riser are required in an ongoing program to attain good yields.

Lightening of castings, if acceptable by the customer, will also reduce metal melting requirements and total energy used. The change may be in design of casting section thickness or closer tolerance to produce a casting with mold wall movement and "swell". The effect of weight reduction is shown in Figure 2-20.

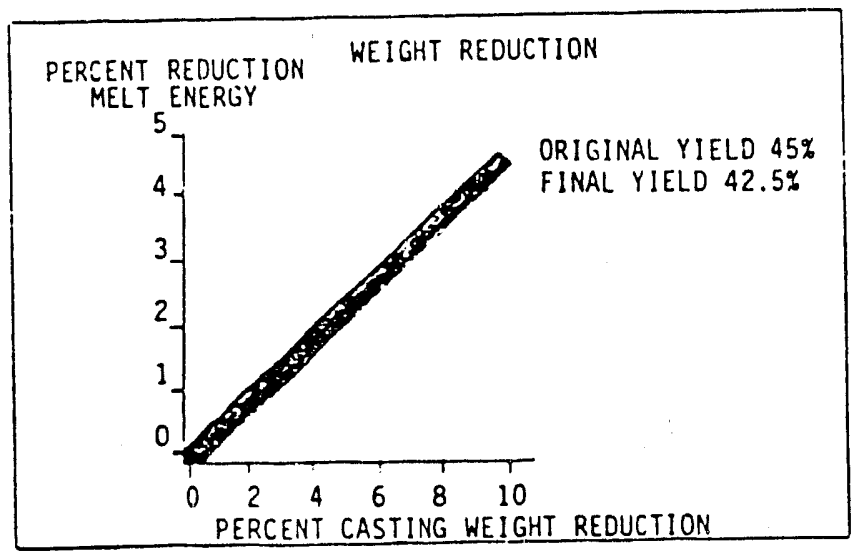

FIGURE 2-20. EFFECT ON MELT ENERGY OF REDUCING CASTING WEIGHT

(Hayes Albion)

Scrap:

Reduction of scrap is of utmost importance in all foundries for overall cost reduction and energy savings. Figure 2-21 shows the melt energy savings when scrap is reduced from 10 percent to zero. There is an approximately linear relationship of energy reduction to scrap reduction; $1 . e$. , one percent scrap reduction saves one percent in energy input. 


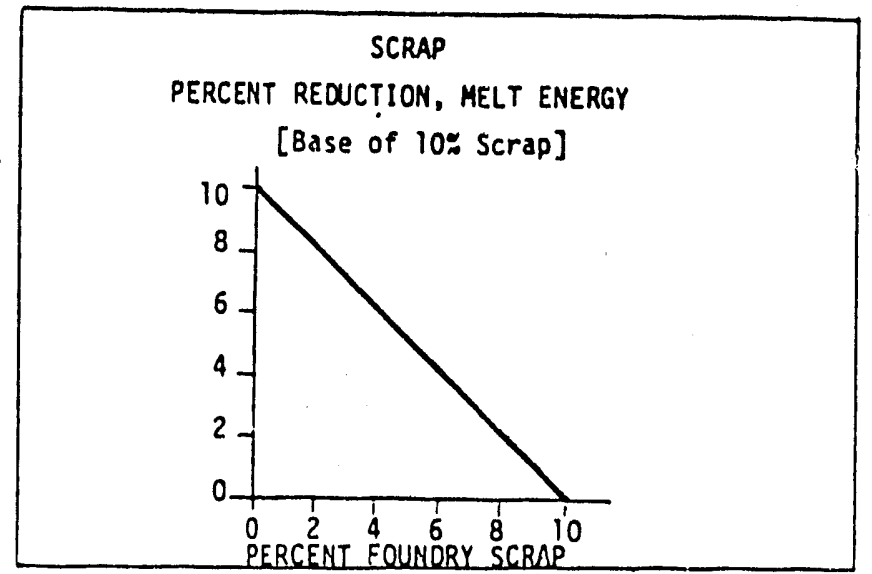

FIGURE 2-21. EFFECT ON MELT ENERGY BY REDUCING SCRAP

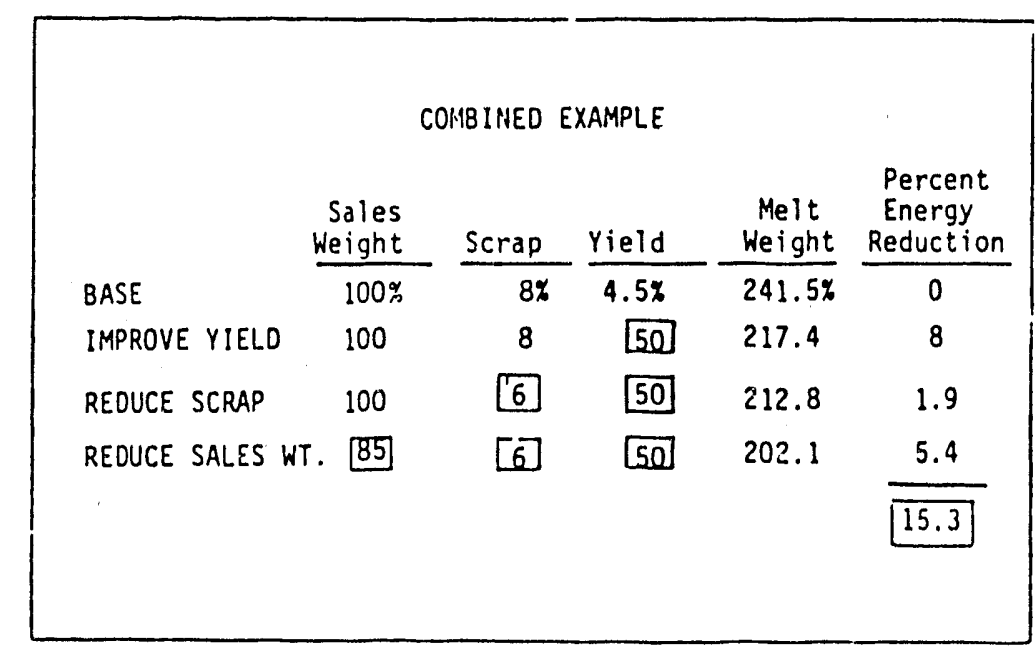

FIGURE 2-22. EXAMPLE OF EFFECT ON MELT ENERGY WITH COMBINED IMPROVEMENTS IN YIELD, SCRAP AND CASTING WEIGHT

Grinding and Machinery:
Losses due to machining away parts of the casting and grinding to remove ingate pads etc. must be minimized by design and careful positioning of ingates on the casting. Cooperation between customer's design engineer, on initial casting configuration, and the pattern maker is essential. 
For an energy management program to be fully effective foundry management should establish the position of "Director of Energy Conservation". The functions of this office would be:

- Establish the total energy cost per unit for each department or division.

- Perform in-plant inspections to identify energy conservation opportunities.

- Establish and maintain an on-going energy conservation program in each department.

- Establish an in-house training program for department supervisors.

- Analyze future energy requirements.

- Assist in establishing plans and capital investment requirements for implementation of conservation programs.

- Provide personal contact between various utility companies.

A single person cannot physically handle all the above assignments; the Director of Energy Conservation must form a committee comprised of top level management people and other members of virtually all departments of the foundry such as melting, heat treating, mold and pouring, cleaning and finishing, and maintenance. The committee thus formed must coordinate a total energy management program to determine what is to be done to reduce the amount of energy used.

After determination of energy reduction measures the committee must follow through with the modifications and changes, to equipment and processes, necessary to accomplish the end results.

Implementation of a full scale energy management program coupled with comprehensive preventive maintenance procedures will, by refining proven and successful foundry management concepts, derive major energy and cost savings.

Efforts to improve foundry profitability by reducing equipment and process downtime, increasing yield through reducing casting weight, reducing scrap and improved scheduling will also payoff in conservation of energy and related cost savings.

All out efforts to reduce energy consumption will gignificantly reduce the cost per ton of shipped casting, which will improve sales and profits. These challenges and opportunities are present in all foundries and should be carefully addressed by foundry management. 
Management approach must be to plan for operating with minimum energy usage. Improved scheduling in terms of when to run partial loads or reduce melting to fewer days but longer hours per day are very basic decistons.

It is not intended that all equipment operate 24 hours per day; careful scheduling can provide for metal to be melted up to pouring temperature at the time it is required, early melting will waste energy due to holding at temperature for long periods.

Changes in processes can be justifled in energy savings, for example: shell or hot box core making conversion to cold box or no-bake methods.

General control of heating and high energy using equipment is necessary to see that it 18 only running when needed. Heat treat furnaces operated on a condensed schedule of several loads back to back will reduce the total energy required to initially heat up the mass of refractory.

Demand limfters for electric power and shifting the production or melting program to take advantage of off-peak power rates is also covered el sewhere.

Advantages of energy efficlent conversions from direct fuel fired equipment to electricity may also be considered in terms of quality control refinements, improved operating conditions, with nolse and exhaust requirements reduced. In nonferxous melting operations the cost advantage of reduced melt losses with electric melting frequently offsets the added energy cost.

A checklist of practical energy conserving suggestions covering plant operations for management to investigate is included in Section 4. 
MAJOR PROCESS CHANGES

MELTING (GAS VERSUS ELECTRIC)

Foundries engaged in the planning of new melt facilities or contemplating mafor changes to existing facilitles should analyze gas versus electric melting, particularly from the standpoint of fuel avallability in the future. The following tables and graphs 111 ustrate the differences in energy consumption and costs for various types of melting practices.

TABLE 2-IX. COST OF ENERGY (EXAMPLES*)

\begin{tabular}{|c|c|c|c|}
\hline $\begin{array}{l}\text { Energy } \\
\text { Source } \\
\end{array}$ & $\begin{array}{l}\text { Energy Cost } \\
\text { per unit } \\
\text { Dellyered }\end{array}$ & $\begin{array}{l}\text { Conversion } \\
\text { Factor }\end{array}$ & $\begin{array}{l}\text { Energy Cost } \\
\text { per Therm } \\
\text { (100,000 BTU) }\end{array}$ \\
\hline Electrictity & S. .04/KWH & 3415 8TU/KWH & S 1.172 \\
\hline Natural Gas & $\$ 2.50 / 1000 \mathrm{CF}$ & $10008 \mathrm{TU} / \mathrm{CF}$ & $\$ .250$ \\
\hline Fuel oil & S. .45/GA1 & $144,000 \mathrm{BTU} / \mathrm{Gal}$. & S.312 \\
\hline Propane & s. .35/Gal & 93.000 BTU/Gal. & 5.376 \\
\hline Coke & S. .075/Lb. & $12,690 \mathrm{BTU} / \mathrm{Lb}$. & $\$ .590$ \\
\hline Cod 1 (Bitumimous) & s. $.0175 / \mathrm{Lb}$. & 14.030 BTU/Lb. & 3.124 \\
\hline
\end{tabular}

Note: Costs of fuels have wide variations with regards to location all governmental control. The resder should research his particular situation with fuel costs. Moreover, avallabllity of fuels rather than costs is emphasicad in this paper.

Energy usage by alternate fuels is shown on the following Table 2-X.

T'ABLE 2-X. ENERGY REQUIREMENTS FOR MELTING AT 100\% POWER UTILIZATION

\begin{tabular}{|l|c|c|c|c|c|}
\hline \multicolumn{7}{|c|}{ ENERGY CONSUMPTION IN KHH PER TON } \\
\hline METAL & $\begin{array}{c}\text { TEMPERATURE } \\
\left({ }^{\circ} \mathrm{F}\right)\end{array}$ & $\begin{array}{c}\text { HEAT CONTENT } \\
\text { KHH/TON }\end{array}$ & $\begin{array}{c}\text { THEORETICAL } \\
\text { OIL-FIRED }\end{array}$ & $\begin{array}{c}\text { GAS ANO } \\
\text { COKE-FIRED }\end{array}$ & $\begin{array}{c}\text { ELECTRIC } \\
(* * *)\end{array}$ \\
\hline Aluminum & 1.400 & 295 & $1,406 *-2,138^{* *}$ & N.U. & 500 \\
Copper & 2.300 & 190 & $1,523 *$ & N.U. & 334 \\
Gray Iron & 2.750 & 340 & N.U. & $801 * * *$ & 500 \\
Steel & 3.000 & 363 & N.U. & N.U. & 606 \\
\hline
\end{tabular}

References:

"Crucible Hanabook, Crucible Institute.

* "Stahl Specialty Company (Reverberatory Furnace).

**:Cupola Handbook. AF5, 1965, P.292.

*** Published Data by Induction and Arc Furnace Companies. 
Example: Asgume a requirement to operate $\mathbf{s i x ~ 2 , 0 0 0 ~} \mathrm{lbg} / \mathrm{hr}$ aluminum meltere with overall yearly utilization of 70 percent (no preheat).*

\begin{tabular}{|c|c|c|c|c|}
\hline Furndce & $\begin{array}{l}\text { Melting Therms } \\
\text { Per Ton } / Y r\end{array}$ & $\begin{array}{l}\text { Holding Therms } \\
\text { Per Ton } / Y r\end{array}$ & $\begin{array}{l}\text { Therms/Ton } \\
\text { Per Year }\end{array}$ & Cost/Year \\
\hline Gas/OIl Reverb. & 304,760 & 72,489 & 377,249 & $94,300 / 117,700$ \\
\hline Gas/0il Crucible & 288.000 & - & 288,000 & 72,000 \\
\hline Coreless Insuction & $\therefore \quad 1101,798$ & 6,231 & 108,022 & 126,386 \\
\hline Channel Induction & $11 / 1 / d 4$ & 3,232 & 74,976 & 87.722 \\
\hline Elect. Reverb. 1 & $88,565 \quad$ & 1,200 & 90,065 & 105,376 \\
\hline
\end{tabular}

* Note: Above costs should be adjusted for particular gituation and user energy rates. Also if $860^{\circ} \mathrm{F}$ preheat is utilized, gas/oll costa may be reduced approximately $\$ 24,500$. Preheating for electric melt reduces costs approximately $\$ 13,000$.

Energy only cost differences shows advantage for channel induction and gas crucibles, however, for cost justification analyses, other factors such as capital cost, maintenance, melt $108 s$ due to oxidation and general process variable should be taken into account on an individual basis.

MELTING (COKE VERSUS ELECTRIC)

\section{Coke Fuel for Melting in Cupolas}

The most efficient cupola system is a highly utilized large scale, uninterrupted operation. This will present the best metal to coke ratio. Provided tinat the coke ratio does not change during melting, the only additional coke charges made are to compensate for varlatione in operation.

The length of campaign will also be reflected in bed coke usage, with ratios as low as $1: 1$ for short dally melting cycles, also delay in blast-on time, after igniting the coke bed, allows excessive burn-out and waste.

Distribution of energy from cupola coke is shown as follows:

\section{Percent}

Heat in melted iron

Sensible heat in stack gas 
Modifications to the conventional cupolas to recover much of the stack 108s is feasible by use of the recuperative hot blast techniques, but a foundry may decide againgt this method because of excessive capital costs and tending to plug. Divided blast systems, where the tuyeres are located in two rows, separated by approximately 36 inches, is proven to increase top temperatures and reduce coke. Coke aavinge is also possible by enrichment of the blast air by 2.0 to 4.0 percent oxygen.

Injection of coke breeze to reduce fuel cost plus use of Anthracite coke and shredded auto tires, as an energy and carbon plck up source, are other methods of gavings, however, in all cases the degres of aavings is proportional to the capital cost and/or operating problems incurred. These energy reduction methods are all in use, but the total combination of savings is only available under experimental gituations. Capital costs of over 1.0 million dollars is reported to be involved in upgrading cupolag for full maximization of energy savings.

\section{Electric Furnace Molting}

Furnaces for melting with electric power are available as follows:

- Direct Aro

- Coreless thiuction

- Channel $\mathbf{T}$ pl Induction

- Resigtanci lype - Reverberatory Furnaces

The efficiency of electric melting is highest where a full bath of metal at liquid stage 41 being heated. Ability to maintain temperature within close tolerance and melt on a continuous or intermittent basis is of major advantage in ectric melting. Other applications of electric power usage, as applitid to the melting of metal, is covered elsewhere in this study.

\section{COST COMPARISON COMPUNHB ANALYSIS}

Computer models have been developed to determine cost comparisons between induction and cispola melting for iron, and between induction, electrical resistance, and gas-fired melting for non-ferrous metals. These modela can be accessed through the EPRI Center for Materialo Production, Plttsburglin, Penneylvania; or the CMP Foundry Office, Arlington Heights, Illinois.

\section{LADLE PREHEAT (GAS VEHSUS ELECTRIC)}

Electric ladle drying and preheating coste can be cut as much as 508, depending on utility rates, by use of electric silicon carbide globar type alements utilized in confunction with correctly dealgned ladle covers and controls. 
The high thermal efficiency of electric ladie heaters, as compared to gas combustion devices in which a very large part of the avallable heat is wastefully vented to atmosphere, will afford maximum energy savings. As an added feature automatic programmed temperature control w111 provide close temperature control without overheating.

Figure 2-23 ahows attainable curing and preheating cycles for 2,000pound, 30-inch diameter ladle with a $65 \mathrm{~kW}$ heater.
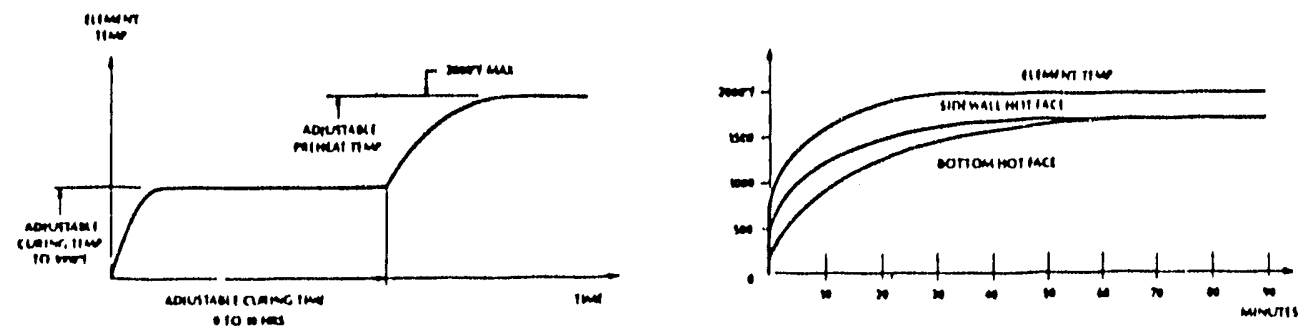

FIGURE 2-23. ELECTRIC LADLE PREHEATER PERFORMANCE ( $30 "$ DIAMETER LADLE)

Units avallable to suit ladle sizes are as follows:

$\underline{\mathrm{kW}}$

25

40

65

100
Ladle Size

$$
\begin{aligned}
& 17-1 / 2-21-1 / 2 \\
& 21-1 / 2-27 \\
& 27-34-1 / 2 \\
& 34-1 / 2-43-1 / 2
\end{aligned}
$$

Capac1ty-Pounds

$$
\begin{array}{r}
500-1,000 \\
1,000-2,000 \\
2,000-4,000 \\
4,000-8,000
\end{array}
$$

\section{Insulating Board Linings}

A recent innovation in ladle lining practice ts the use of disposal insulating board linings. The boards resemble conventional wall board In consistency, and are produced from elther silica or magnetite refractory grains bonded with an organic resin. The boards are supplied as segments that are fltted together to form the walls of a ladle lining, and are backed by a permanent refractory safety lining. The gaps between the boards and the safety are filled with dry sand. A separate board ladle bottom is also often used. These same insulating materlals are avallable in pre-shaped complete linings for small ladles as well. 
The main advantage is that these 1 inings do not require preheat and are used as "cold linings". Although the cost of these linings ls high, energy savings can often compensate. These Iinings are designed to be used only once and then replaced in order to insure the highest quality of castings. Use of the boards for more than one heat (fill) causea rapid breakdown of the refractory and resulta in deterioration of casting quality. 
This section providea all necessary charts, graphs, tables, and mathematical formulas for the development of energy avings in guantitative form for:

- Electrio power and cost savings relative to the melting of metal in all avallable types of furnaces. By utilizing hypothetical mathematical models it will be shown how to cut energy cost and/or consumption by improving power factors, installing demand limit controls, changing to "off-peak" melting and demand shifting.

- Gas energy reduction relative to melting, heat treating, and ladle preheating. By utilizing hypothetical mathematical models it will be shown how to reduce energy cost and/or consumption by improving combuation efficiencies, inatallation of ceramic fiber lining, installation of covers, and adding combustion air preheating.

- Reduction of coke usage in oupola melting by upgrading equipment guch as adding hot blast via stack gas recuperation divided blast and oxygen enrichment. Also shown is the comparat.ve energy usage for cupola versus electric melting. 


\section{A. ELECTRIC MELTING}

\section{GENERAL}

As stated previously in Section 1 of this report, approximately $34 \%$ of the total energy input (all fuels) to a typlcal steel foundry is in the form of electricity. of this $34 \%$ approximately $60 \%$ is attributed to the melting of metal. This section deals with energy and cost savings in electric melting operations and covers the following areas.

- Furnace operation

- Energy usage

- Demand

- Demand contro1

- off-peak melting

- Demand shifting

- Power factor correction

\section{INPUT DATA}

The required input data needed to analyze present melting operations, :m the standpoint of energy consumption 1s:

- Electric utility b11ls for the past twelve months

- Kllowatt demand load profile

- Rate schedule for summer and winter "Time of Day" bllling

The electric energy usage for a typlcal calendar year for a hypothetical foundry is shown in Table 3-I. The kllowat demand load profile covers a period of 48 hours and represents an electrical demand requirement for electric melting (See Flgure 3-1). The load profile was developed from the kflowatt demand printout (See Table 3-II). From Table 3-II, it should be noted that the kllowatt demand for each flve-minute interval for each 24-hour perlod 18 listed. 
TABLE 3-I . ELECTRICAL POWER USAGE

\begin{tabular}{|c|c|c|c|c|c|c|c|c|}
\hline BILLIIIO PERIOD & ENERGY KHH & $\begin{array}{l}\text { BILLING } \\
\text { DEMANO }\end{array}$ & $\begin{array}{l}\text { POWER } \\
\text { FACTOR }\end{array}$ & $\begin{array}{l}\text { ENERGY } \\
\text { CHARGEE }\end{array}$ & $\begin{array}{c}\text { FUEL } \\
\text { AD JUSTMENT } \\
\text { CHARGE }\end{array}$ & $\begin{array}{l}\text { DEMAND } \\
\text { CHARGE }\end{array}$ & $\begin{array}{l}\text { GROSS } \\
\text { BILL }\end{array}$ & NET BILL \\
\hline JAlivary & 376,800 & 2,291 & .97 & 11,570 & (638) & 5,394 & 17,602 & $1 \$ 16,964,00$ \\
\hline FEERUARY & 386,400 & 2,255 & .98 & 10,757 & $(647)$ & 5,318 & 16.722 & $16,075.00$ \\
\hline MARCH & 367.200 & 2,279 & .99 & 10,136 & $(698)$ & 5,301 & 16,145 & $15,497,00$ \\
\hline APRIL & 415,200 & $N / A$ & $\mathrm{~N} / \mathrm{A}$ & $N / A$ & $N / A$ & $N / A$ & N/A & $16,728,00$ \\
\hline MAY & 376,800 & 2,266 & .98 & 10,413 & (548) & 5,341 & 16,332 & $\begin{array}{r}15,784,00 \\
\end{array}$ \\
\hline JUlie & 376,800 & $N / A$ & $\mathrm{~N} / \mathrm{A}$ & $N / A$ & $N / A$ & $N / A$ & $N / A$ & $15,900,00$ \\
\hline JULYY & 228,000 & 2,281 & .90 & 0,646 & $(450)$ & 5,373 & 12,469 & $1 \quad 12,019,00$ \\
\hline AUGUST & 384,000 & 2,262 & .99 & 10,748 & $(476)$ & 5,333 & 16,557 & $16,081,00$ \\
\hline SEPTEMBEER & 434,400 & 2,404 & .99 & 12,117 & $(509)$ & 5,634 & 18,260 & $17,751,00$ \\
\hline OCTOBER & 432,000 & 2,443 & .98 & 12,650 & $(505)$ & 5,717 & 18.872 & $18,367,00$ \\
\hline NOLEMBER & 468,000 & 2,500 & .98 & 14.149 & $(5: 1)$ & 5,838 & 20,508 & $19,987.00$ \\
\hline DECEYBER & 427,200 & $N / A$ & .99 & $N / A$ & (256) & $N / A$ & 15,029 & $14,772,00$ \\
\hline TOTALLS & $4,672,800$ & & & & & & & $\$ 195,925.00$ \\
\hline
\end{tabular}

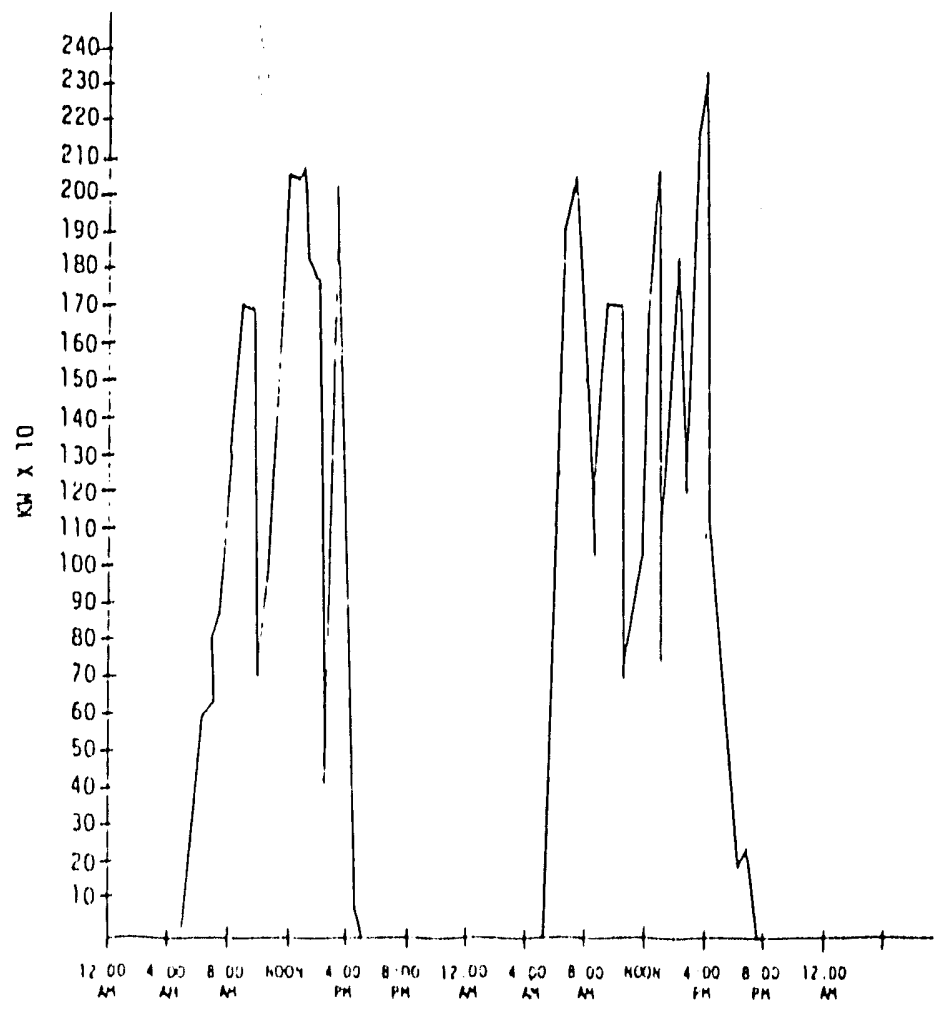

FIGURE 3-1. ELECTRICAL LOAD PROF ILES 
TABLE 3-II. KILOWATT DEMAND PRINTOUT

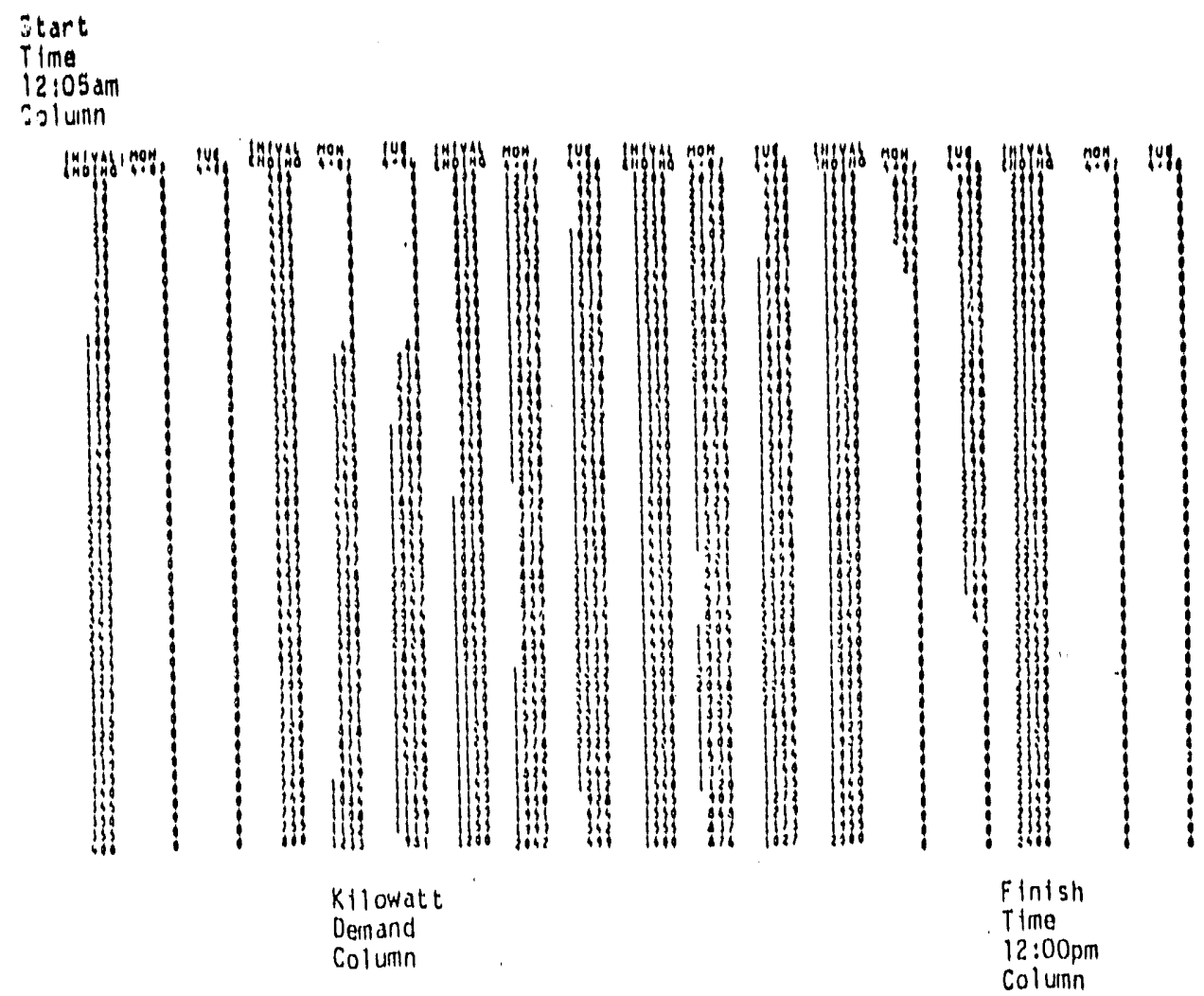

\section{LOAD PROFILE DEVELOPMENT}

Foundries with a separate electrical service to thelr melting furnaces can develop their own in-house kilowatt load profile in the following manner. Prepare a chart, using graph paper with one-tenth of an Inch/to one inch divisions, recording time along abscissa axis and kllowatt demand along ordinate axis. Along the abscissa axis set out the "time of day" billing hourg. Setting up the graph in this manner will Indicate if the high kllowat demands are occurring during the "on peak" hours (See Figure 3-2). From the kllowatt demand printout, record the thirty minute kllowatt demands for chosen time perlods. When all 30minute kllowatt demands have been recorded, connect all points to obtain profile of load. The procedure for developlng a winter kilowat toad profile is the same as "summer", but the "time of day" billing hours change (See Figure 3-3).

Foundries that are not provided with a kllowat demand printout for their electric melting operation or have only one electrical service for both melting and general plant service will need to tnstall submetering of the service feeders. 
Uaing a threemphase tap-type recording ammeter and a clipon type power factor meter the necessary data can be obtained to find the kilowatt demand.

\section{Example}

If the ammeter recorded 400 amperes with a 0.80 power factor the kdlowatts would be as follows:

$$
\begin{gathered}
\frac{I \times E \times 1.73 \times P F}{1000} \\
\frac{400 \times 480 \times 1.73 \times .80}{1000} \quad \because 265 \text { kllowatts }
\end{gathered}
$$

From the above reading the kilowatt load profile can be developed. 

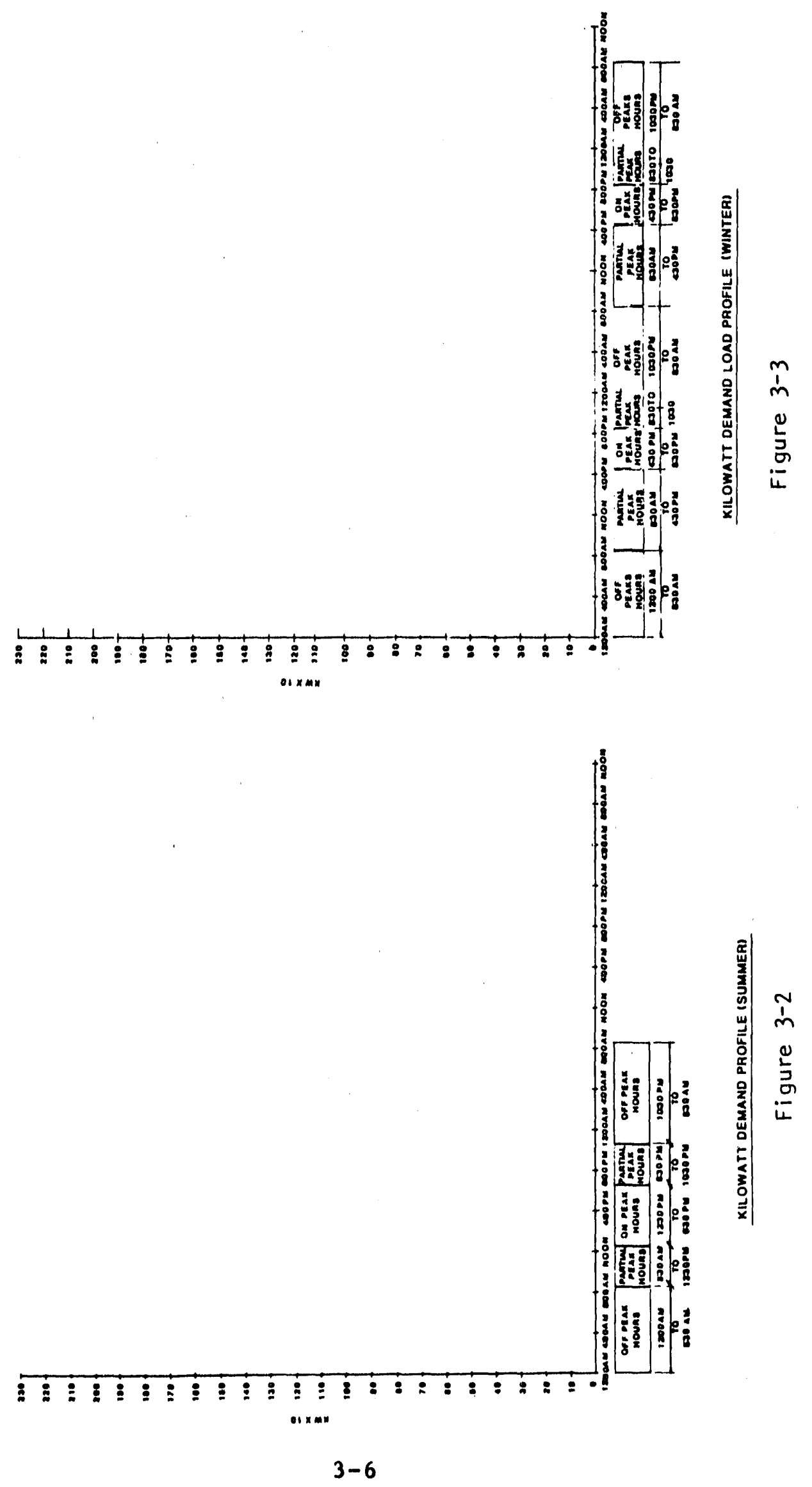
By utilizing "off-peak" hours for metal melting, substantlal cost savings can be realized through lower ing the demand and energy charges.

Figure 3-4 111ustrates a total demand load of 2,300 kilowatts, of this amount approximately $59 \%$ or $1,357 \mathrm{~kW}$ is attributed to melting of metal, the remainder is base plant electrical load.

The following sample calculations illustrate the electrical cost for demand, energy and fuel adjustment charges for melting in on-peak and offpeak hours.

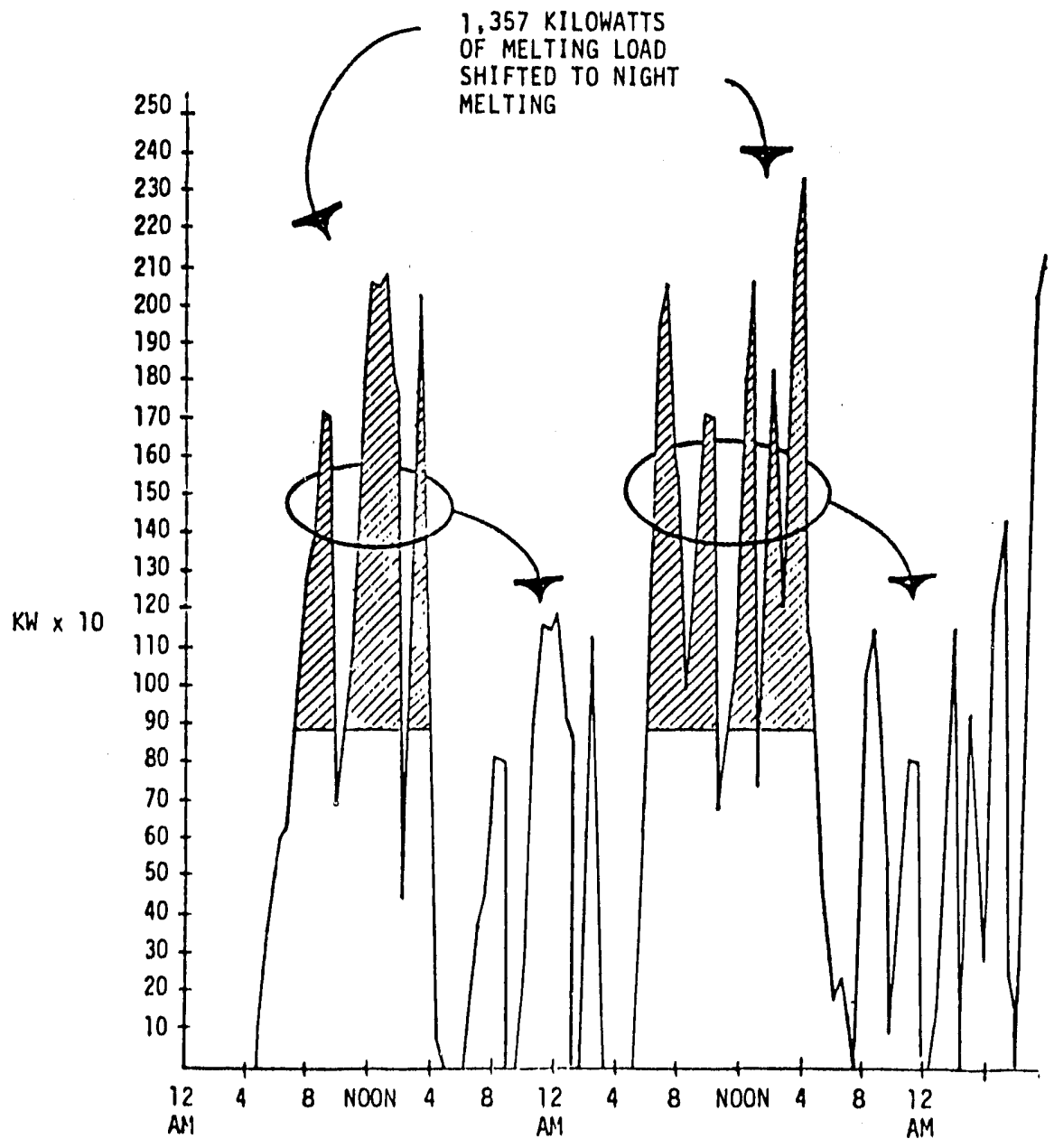

FIGURE $3-4$ 
SAMPLE CALCULATION (On-Peak Period) (Figure 3-4 - "Before")

Demand Charges:

On-peak per kilowatt of maximum demand

Total on-peak $1369 \mathrm{~kW}$ at $\$ 2.50$

$\$ 3,422$

Plus "partial peak" per kilowatt of maximum demand

Total partial peak $1363 \mathrm{~kW}$ at $\$ 0.30$

$\$ 408$

Plus off-peak, per kilowatt of maximum demand

Total off-peak $1358 \mathrm{~kW}$ no charge

$\$$

Subtotal

$\$ 3,830$

Energy Charges:

0n-peak, per kllowatt hour: $12: 30 \mathrm{pm}$ to

$6: 30$ pm 4-5 hrs/day

Total kilowatt hours $98,571 \times \$ 0.022 / \mathrm{kWh}$

$\$ \quad 2,168$

Partial peak, per kilowatt hour: 8:30 am to

$12: 30 \mathrm{pm}$ and $6: 30 \mathrm{pm}$ to $10: 30 \mathrm{pm} 8 \mathrm{hr} /$ day

Total kilowatt hours $145,135 \times \$ 0.019 / \mathrm{kWh} \quad \$ 2,757$

Off-peak, per kilowatt hours: $10: 30 \mathrm{pm}$ to

8: 30 am $10 \mathrm{hrs} /$ day

Total k1lowatt hours $183,875 \times \$ 0.010 / \mathrm{kWh}$

$\$ \quad 1,839$

Subtotal

$\$ \quad 6,764$

Fuel Adjustment Charges:

Total k1lowatt hours $=427,582 \times \$ 0.04063$

$\$ \quad 17,372$

Grand total for (demand, energy and fuel ad fustment charges)

$\$ 27,966$

Above calculations are based on normal day shift working hours and sumer "time of day" billing rates for a 30-day perlod. Figures are abstracted from power company metered print-outs. 
Off-Peak Melting (Figure 3-4 - "After")

\section{Demand Charges:}

"On-peak" per kllowatt of maximum demand

Total on-peak none at $\$ 2.50$

$\$$

Plus "partial peak" per kilowatt of maximum demand

Total partial peak none at $\$ 0.30$

$\$ \quad 0$

Plus "off-peak" per kllowatt of maximum demand

Total off-peak 1239 at no charge

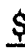

Subtotal

$\$$

0

\section{Energy Charge:}

"On-peak", per kllowatt hours: $12: 30 \mathrm{pm}$ to $6: 30 \mathrm{pm} 6 \mathrm{hrs} / \mathrm{day}$ Total kllowatt hours none $x \$ 0.022 / \mathrm{kWh} \$$

"Partial peak" lillowatt hours: 8:30 am to $12: 30 \mathrm{pm}$ and $6: 30 \mathrm{pm}$ to $10: 30 \mathrm{pm} 8 \mathrm{hrs} /$ day

Total kilowatt hours none $x \$ 0.019 \mathrm{kWh}$

"Off-peak" kilowatt hours: 10:30 pm to 8:30 am $10 \mathrm{hrs} /$ day

Total kflowatt hours $427,582 \times \$ 0.010 / \mathrm{kWh}$

$\$ \quad 4,275$

Subtotal

$\$ 4,275$

Fuel Adjustment Charges:

Total kilowate hovrs $=427,581 \times \$ 0.04063$

Grand total for (demand, energy and fuel adjustment charges)

Potentlal cost savings by shifting to off-peak melting would be $\$ 27,966-\$ 21,647 \$ 6,319$ or $22.5 \%$ savings for the 30 -day period. 
If night melting is not possible, demand shifting and control will. permit metal melting during normal "on-peak" day time hours and still save substantial costs. Demand shifting will extend the melting period; this permits the sequential operation of the furnaces, thereby reducing the peak maximum demand.

With uncontrolled operation, large kilowatt demands are developed which produces low demand factors and low efficiency of power usage. Figure 3-5 is representative of an uncontrolled operation of power input to several furnaces. Figure 3-6, Indicates how the kilowatt demand can be reduced by extending the hours of melting operations with the demand limit set at 1,700 kilowats. The sample calculations illustrate the potential cost savings if demand shifting and control is utilized. To insure complete control of a set maximum demand an automatic demand controller should be installed, this controller automatically regulates or Iimits operation in order to prevent a set maximum demand from being exceeded. With the monitored information, the controller can calculate when an overload of the set demand will occur. The controller will delay any shed action to allow time for loads to shed normally. When it is determilied that it will be necessary to shed one or more loads to keep from exceeding the set kilowatt demand, the controller will shed the necessary load. This means that shedding will occur only once during a demand interval and maximum use of available power will be realized.

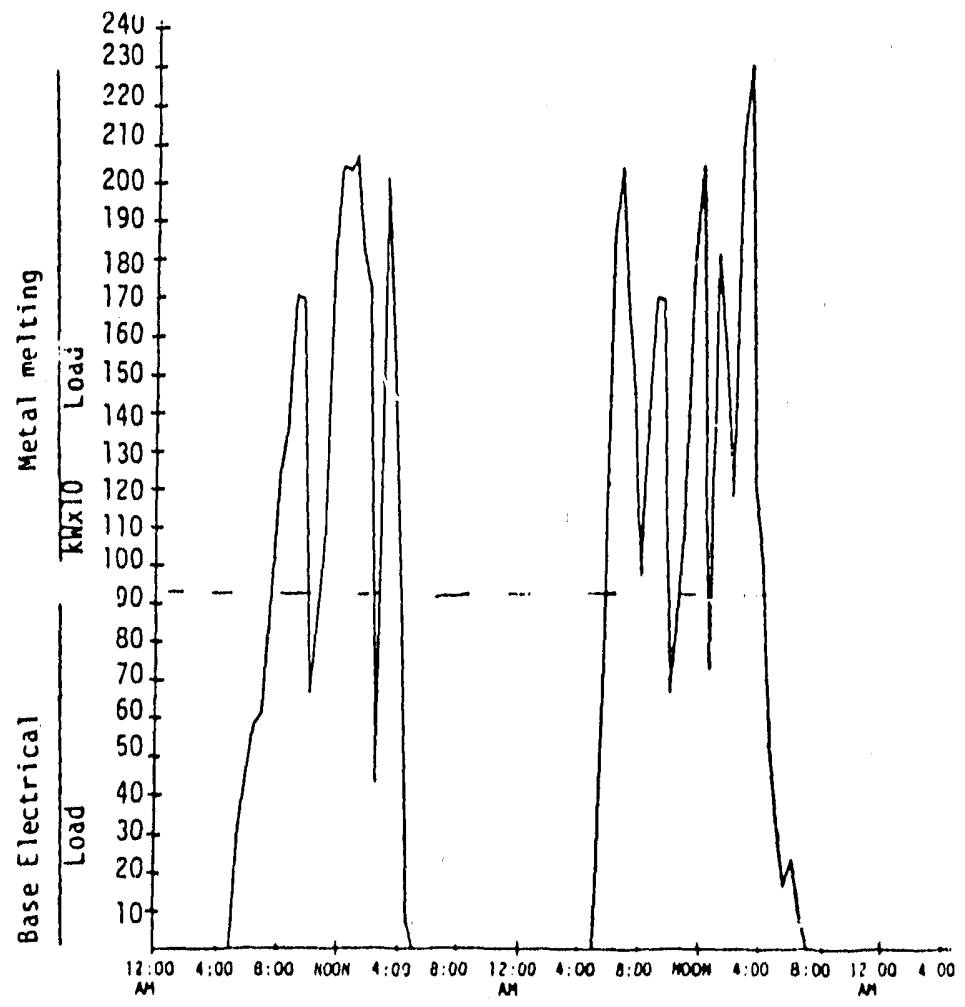

FIGURE 3-5. ELECTRICAL LOAD PROFILE (UNCONTROLLED) 


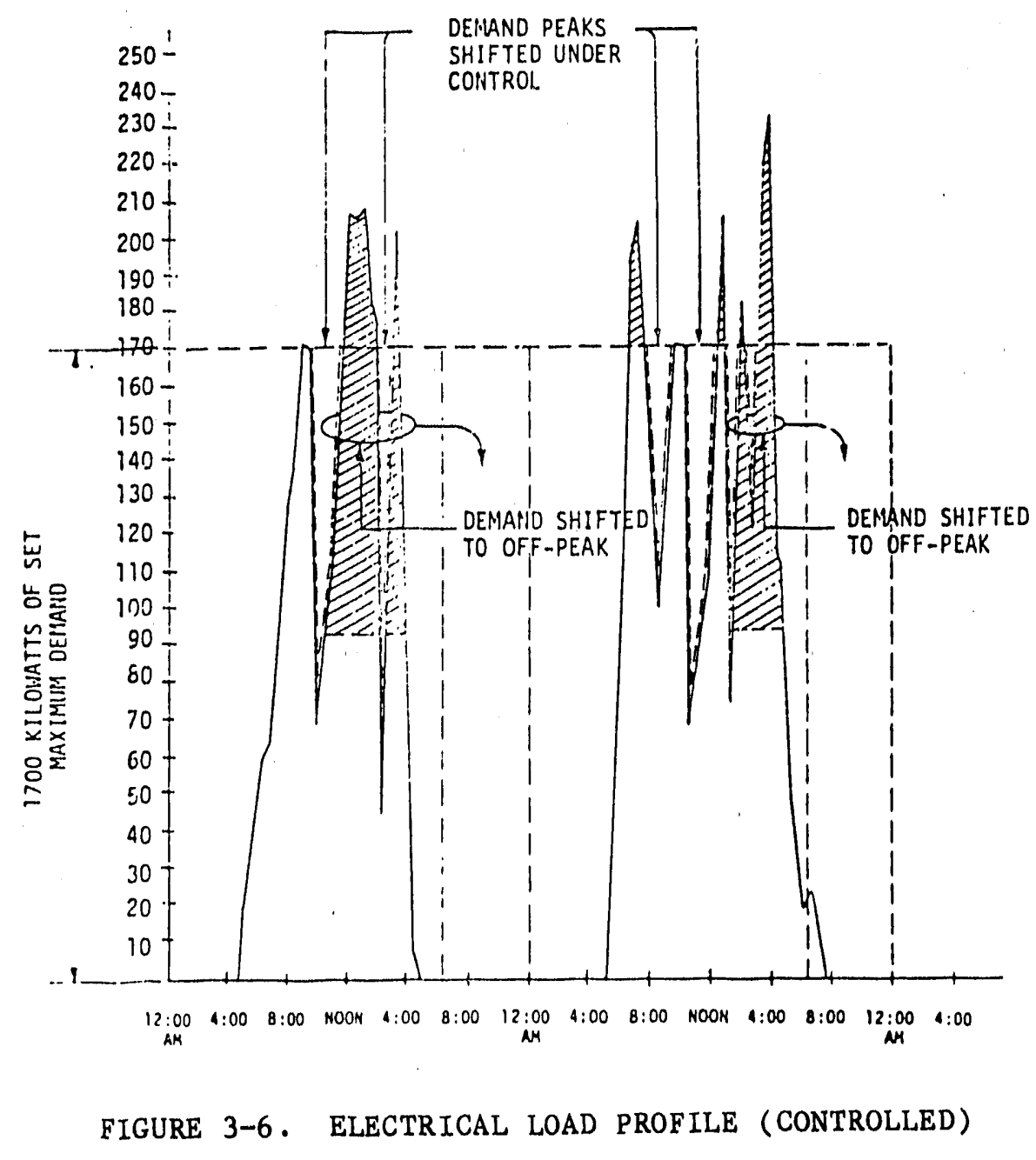


Sample Calculations (Uncontrolled Operation - Figure 3-5)

Demand Charges:

"On peak" per kllowatt of maximum demand

Total on peak $1,0333 \mathrm{kw}$ at $\$ 2.50$

$\$ 2,507$

Plus partial peak per kilowatt of maximum demand

Total partial peak $998 \mathrm{kw}$ at $\$ 0.30$

$\$ 299$

Plus "off-peak per kilowatt of maximum demand

Total off-peak $994 \mathrm{kw}$ no charge

$\underline{\$}$

Subtota1

$\$ 2,806$

Energy Charge:

"On peak", per kflowatt hour: $12: 30 \mathrm{pm}$ to $6: 30 \mathrm{pm} 6 \mathrm{hrs} / \mathrm{day}$

Total kilowatt hours $98,971 \times \$ 0.022 / \mathrm{kWh}$

$\$ 2,168$

"Partial peak" kilowatt hour: 8:30 am to

$12: 30 \mathrm{pm}$ and $6: 30 \mathrm{pm}$ to $10: 30 \mathrm{pm} 8 \mathrm{hrs} /$ day

Total kilowatt hours $15,135 \times \$ 0.019 / \mathrm{kWh}$

$\$ 2,757$

"Off-peak" per kilowatt hour: 10:30 pm to

8:30 am $10 \mathrm{hrs} /$ day

Total kilowatt hours $183,875 \times \$ 0.010 / \mathrm{kWh}$

$\$ 1,839$

Subtotal

$\$ 6,764$

Fuel Adjustment Charges:

Total kilowatt hours $=427,582 \times \$ 0.04063$

$\$ 17,372$

Grand total for (demand, energy and fuel adjustment charges)

$\$ 26,942$ 
Sample Calculations (Controlled Operation - Figure 3-6)

Demand Charges:

"On peak" per kilowatt of maximum demand

Total on peak none $\mathrm{kw}$ at $\$ 2.50$

Plus partial peak per kilowatt of maximum demand

Total partlal peak $998 \mathrm{kw}$ at $\$ 0.30$

$\$ \quad 299$

Plus "off-peak" per kilowatt of maximum demand

Total off-peak $994 \mathrm{kw}$ no charge

$\underline{\$}$

Subtotal

$\$$

299

\section{Energy Charge:}

"On-peak", per kilowatt hour: 12:30 pm to 6:30 pm $6 \mathrm{hrs} /$ day

Total kilowatt hours none $x \$ 0.022 / \mathrm{kwh}$

"Partial peak" kilowatt hour: 8:30 am to

$12: 30 \mathrm{pm}$ and $6: 30 \mathrm{pm}$ to $10: 30 \mathrm{pm} 8 \mathrm{hrs} /$ day

Total kilowatt hours $145,135 \times \$ 0.019 / \mathrm{kwh}$

"Off-peak" per kilowatt hour: $10: 30 \mathrm{pm}$ to $8: 30$ am $10 \mathrm{hrs} /$ day

Total kflowatt hours $282,446 \times \$ 0.010 / \mathrm{kwh}$

$\$ \quad 2,824$

Subtotal

$\$ \quad 5,581$

Fuel Adjustment Charges:

Total k1lowatt hours $=427,582 \times \$ 0.04063$

$\$ 17,372$

Grand total for (demand, energy and fuel adjustment charges)

$\$ 23,252$ 
DEMAND CONTROL

With a power demand controller installed on the power system supply to the furnaces, maximum kllowatt demand can be controlled.

The controller automatically regulates or limits operation in order to prevent a set maximum demand from being exceeded. The controller predetermines the demand $1 \mathrm{Imit}$ and the demand interval. The sequence of operation is similar to that described under "load shifting and control".

Figure $3-7$, 11lustrates the new load profile with demand set at $1,700 \mathrm{~kW}$. Cost savings are the same as those computed under "Load Shifting and Control."

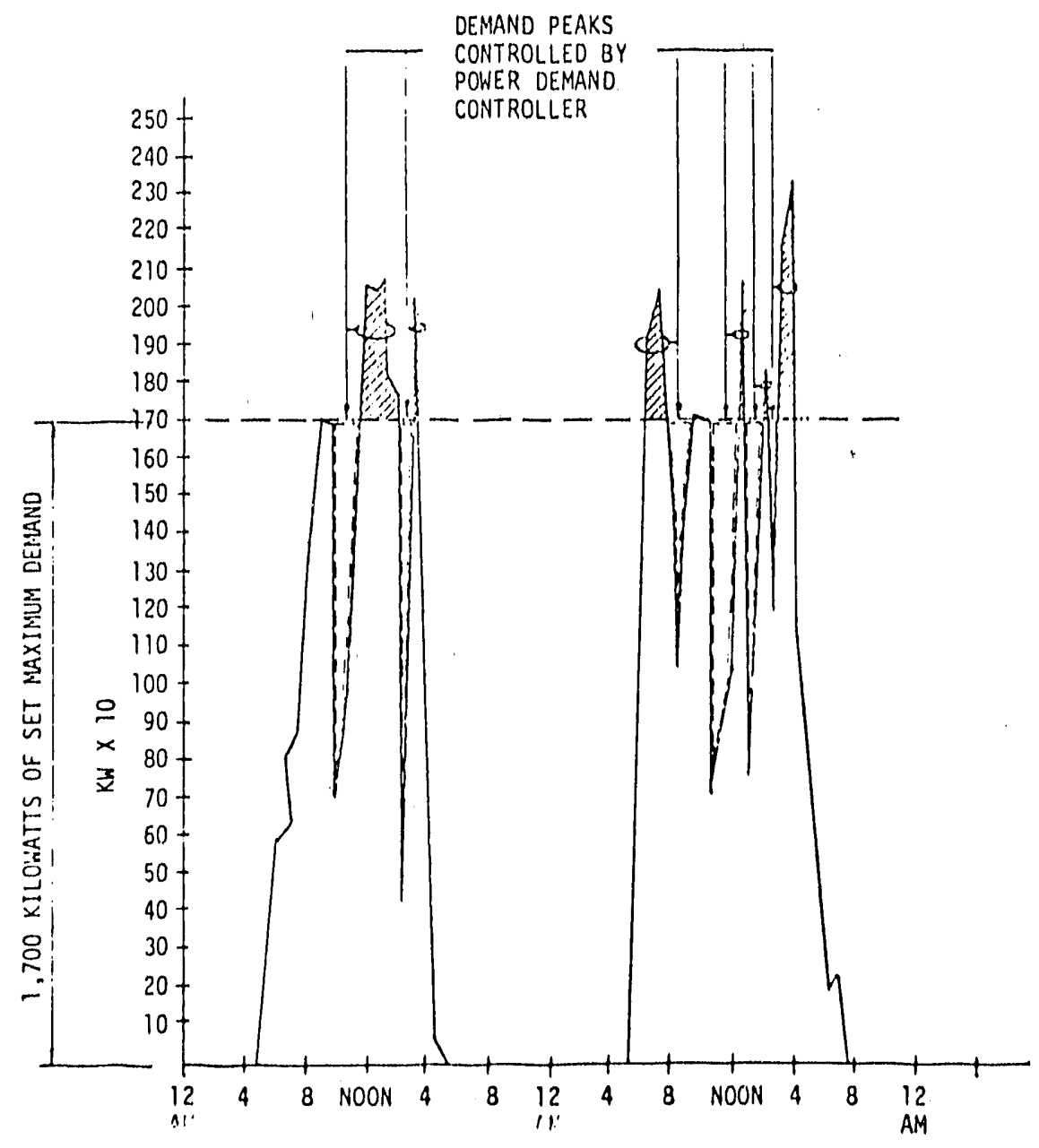

FIGURE 3-7. ELECTRIC LOAD PROFILE (DEMAND CONTROL) 
The electricul efficlency of the coreless induction furnace is approximately 76-81 percent with a power factor of approximately 90-98 percent, the channel furnace is approximately $94-96$ percent $w 1$ th a power factor of $94-98$ percent. With these high power factors designed into the furnaces, no additional correction is necessary.

On the other hand arc furnaces have an approximate power factor of 70\% if capacitors are not installed on furnace transformers. It should be noted that power factor Improvement will not save in-plant energy or reduce the customer's power b111, but will save energy at the utility company power plant thereby reducing the nation's dependence on ofl.

\section{IMPROVED FURNACE DESTGN}

\section{Induction Furnaces}

An 1mproved profile of the power coll reduces the magnetic flux lines penetrating through the outside corners, which in turn minimizes eddy current 1088 , thereby Improving furnace effictency.

Use of castable backup refractory will eliminate the need for cooling colls and save the energy that would otherwise enter into the cooling water. The efficlency of the furnace can be increased as much as $10 \%$ with these impravements. A foundry producing 25 tons a day can save approximately per year. Using representative figures for this example the savings compute as follows:

Total energy required to melt 25 tons of metal per day =

$$
\frac{25 \times 500 \mathrm{kwh} / \mathrm{ton}}{0.76 \% \text { efficiency }}=16,500 \mathrm{kwh}
$$

$10 \%$ improvement $=16,500 \times 0.10=1,650 \mathrm{kwh}$ savings/day

Savings/year at 240 days $=1,650 \times 240=400,000 \mathrm{kwh}$

Average power at $\$ 0.0427=\$ 17,000$ savings/year 


\section{Arc Furnaces}

The Invtallation of water-cooling on the sldewalls of the furnace will reduce downtime necessary for refractory replacement. With installation of water-cooled blocks there is about 108 increase in total furnace productivity; other benefits are:

- 80\% decrease in sldewall brlok consumption

- Reduction of power "on-time" by 138

- 38 anergy savinge

- 88 reduction in electrode consumption

The installation of solid-state furnace controls provides for automatic positioning of the electrodes within the furrace. The control maintaine the arc setpoint more accurately which gives conetant power input and longer refractory life. Constant arc atability provides for a higher through-put, with a higher input power usage. The energy savings that can be realized are approximately 10 percent.

\section{Electric Regigtance Reverberatory Melting Furnace (ERMF)}

Installation of furnace covers over the charging and dipout wells and the bath will gave energy.

\section{Sample Calculation}

potential energy savings in covering a four-square-foot opening based on radiation losses of $20,000 \mathrm{Btu} / \mathrm{s} / \mathrm{SF} / \mathrm{hr}$ for covered furnaces.

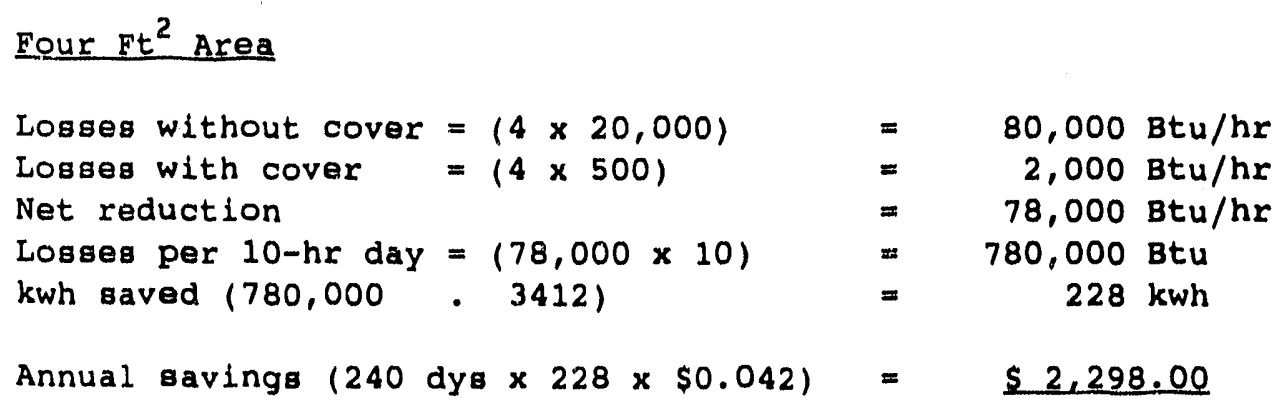

\section{Graphite Rod Holding Furnace}

As the graphite rod holding furnace is not a primary melting furnace, this furnace will not be addressed with regards to lost energy. The efficlency and utilization of energy input for metal holding io high. The power factor is maintained at near unity with this type of unit. 
TABLE 3-III. SUMMARY OF COST SAVINGS

\begin{tabular}{|c|c|c|c|c|c|}
\hline \multicolumn{6}{|c|}{$\begin{array}{l}\text { POTENTIAL ANNUAL COST SAVINGS } \\
\text { FOR ELECTIRCAL ENERGY AND DEMANDI/ }\end{array}$} \\
\hline \multirow[b]{2}{*}{ ITEM } & \multicolumn{2}{|c|}{ PRESENT CONDITIONS } & \multicolumn{2}{|c|}{ POTENTIAL CONDITIONS } & \multirow[b]{2}{*}{$\begin{array}{l}\text { POTENTIAL } \\
\text { ANNUAL COST } \\
\text { SAVIIIGS } \$\end{array}$} \\
\hline & $\begin{array}{l}\text { ENERGY } \\
\text { CONSUMED } \\
\text { KWH }\end{array}$ & $\begin{array}{l}\text { ENERGY } \\
\text { AND DEMAND } \\
\text { COST } \$\end{array}$ & $\begin{array}{l}\text { ENERGY } \\
\text { C.ONSUMED } \\
\text { KWH }\end{array}$ & $\begin{array}{l}\text { ENERGY } \\
\text { AND DEMAND } \\
\text { COST } \$\end{array}$ & \\
\hline Off-Peak Melting & $5,130,984$ & 335,592 & $5,130,984$ & 259,764 & 75,828 \\
\hline $\begin{array}{l}\text { Demand Shifting } \\
\text { and Demand Control }\end{array}$ & $5,130,984$ & 323,304 & $5,130,984$ & 279,024 & 44,280 \\
\hline $\begin{array}{l}\text { Demand Control } \\
\text { Only }\end{array}$ & $5,130,984$ & 335,592 & $5,130,984$ & 323,304 & 12,288 \\
\hline Furnace Covers & 56,272 & 2,363 & 1,406 & 65 & 2,298 \\
\hline $\begin{array}{l}\text { Improved Furnace } \\
\text { Design }\end{array}$ & $3,960,000$ & 169,092 & $3,564,000$ & 152,182 & 17,000 \\
\hline
\end{tabular}

I/ Developed from sample calculations shown previousiy in this text.

1. Potential annual cost savings are based on 240 operating days per year.

2. Energy consumed per year is based on furnace loads only. Does not include plant base loads. 


\section{B. NATURAL GAS MELT ING}

\section{GENERAL CONSIDERATIONS}

This section deals with energy savings in gas melting operations:

Formulas, calculations, and graphs have been simplified within the Scope of the Profect to reflect constant conditions during the process.

To investigate any process in depth, it is essential to establish parameters, calculate the data and plot results on a continuous basis t:o establish the limits of the operation and equipment, and identify any trend $s$.

The work sheet 11 sts the expected parameters for furnaces, burner and ancillary equipment and operational data to complete a "one shot" energy audit. This constitutes a base for any further improvements. A tape measure, thermometer, flue gas analyzer and flow meters will be the tools needed. 
TABLE 3-IV. GAS FURNACE DATA INPUT

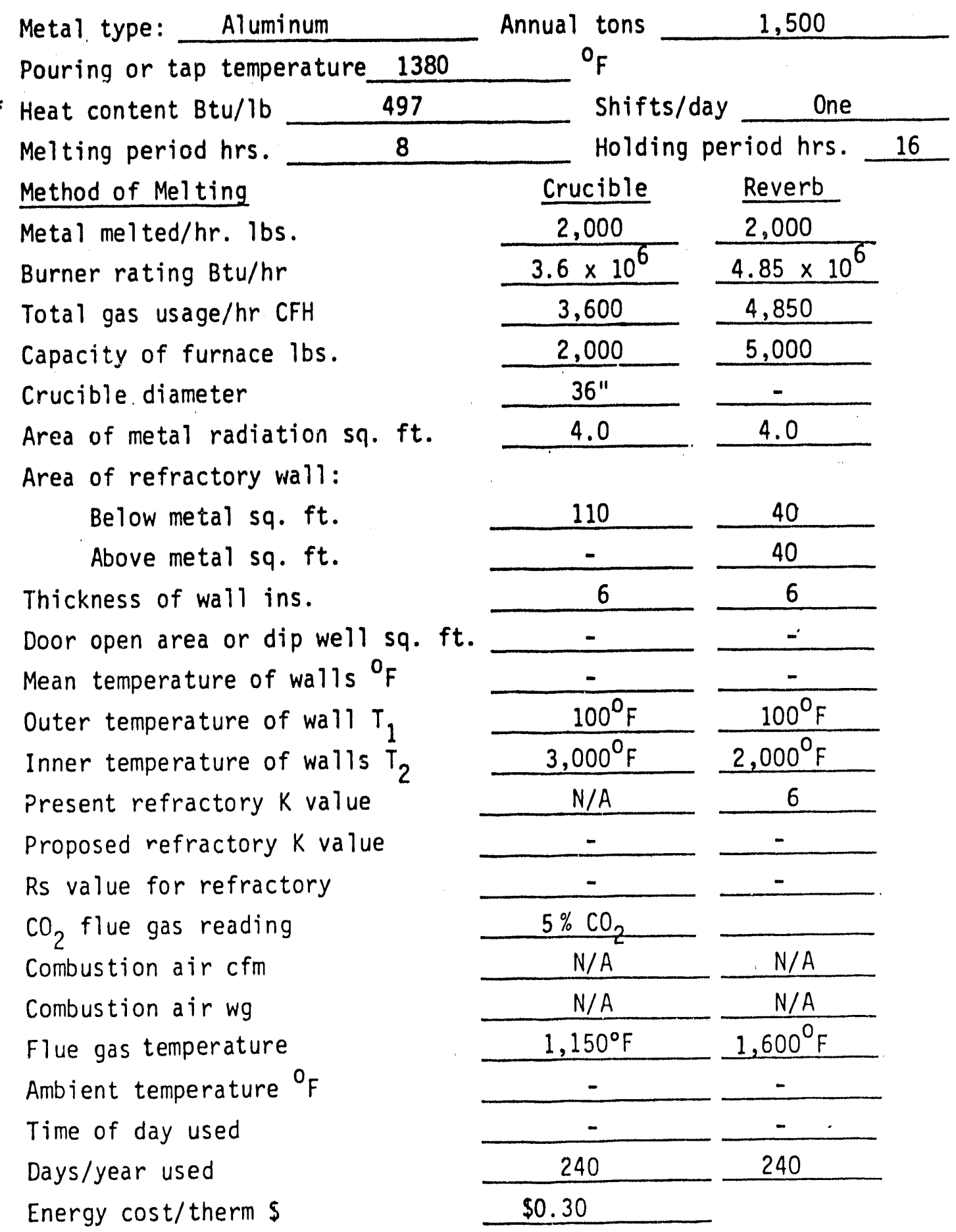

* See Figure 3-8 for input data. 
GRAPHS, TABLES AND CHARTS

The following graphs, tables and charts 111 ustrated here are to be utilized for performing sample calculations for anticipated energy reduction measures.

\section{Heat Content of Metals}

The following graph (Figure No. 3-8) shows the heat content of numerous metals and alloys for varlous temperature ranges:

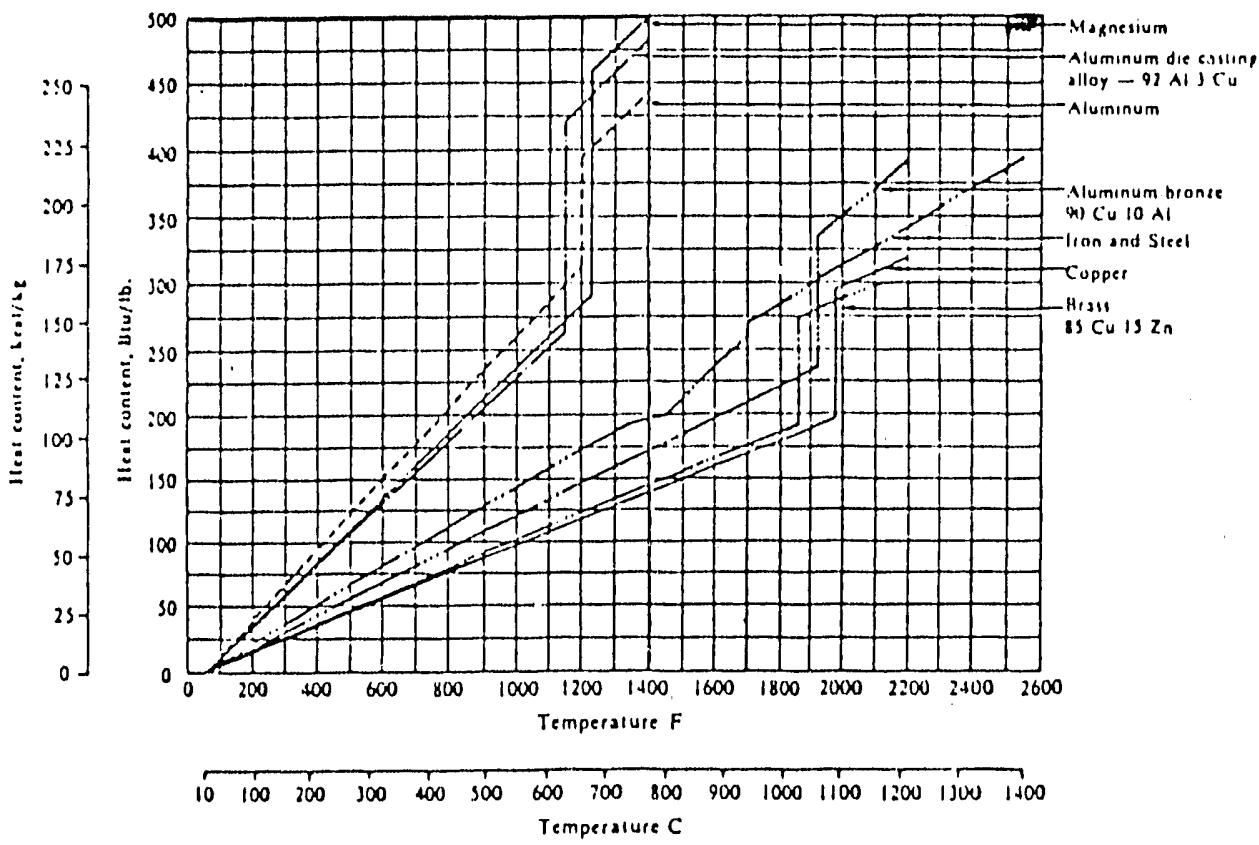

FIGURE 3-8. HEAT CONTENT OF METALS

Example of use: With a $1400^{\circ} \mathrm{F}$ metal temperature, the heat content of aluininum die casting alloy is approximately $500 \mathrm{BTU} / 1 \mathrm{~b}$. 
PERCENT EXCESS AIR FROM $\mathrm{CO}_{2}$ READING

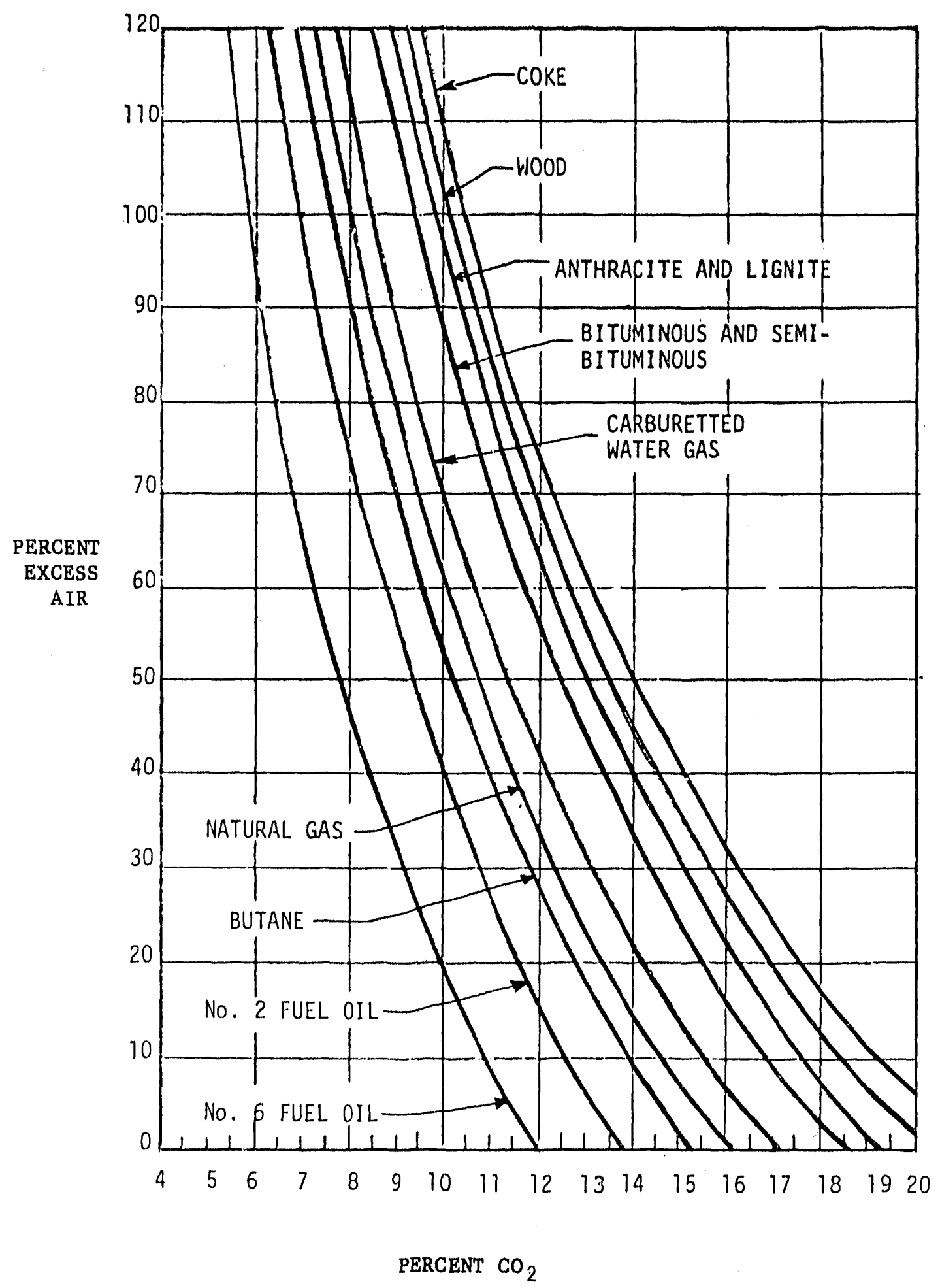

FIGURE 3-9. BURNER CHARACTERISTICS

Source: North American Combustion Handbook.

Example of Use: A combustion analysis shows $6 \% \mathrm{CO}_{2}$ content o the flue gas, with natural gas burning equipment the excess air 18 approximately $90 \%$. 
From North American Combuation Handbook

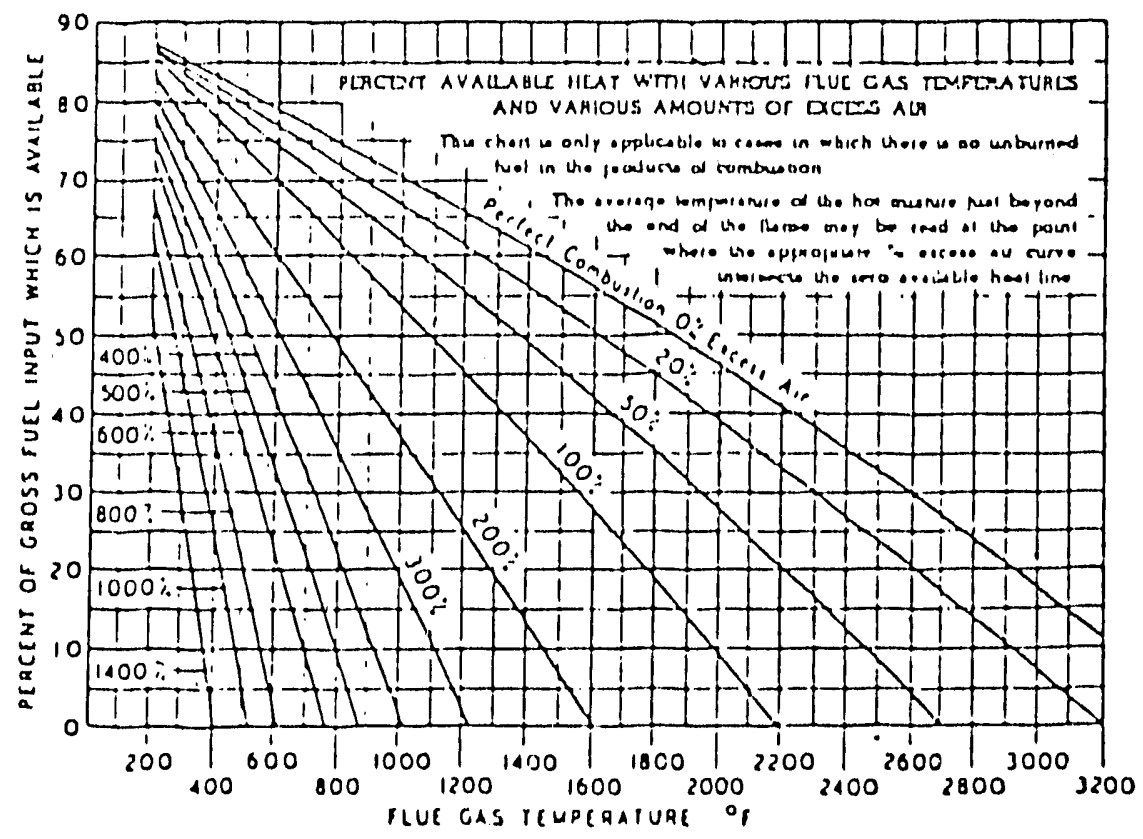

This chart is only applicable to cases in which there is no unburned fuel in the products of combuation.

The average temperature of the hot mixture just beyond the end of the flame may be read at the point where the appropriate "\& Excess Alr" curve intersects the zero available heat line.

Example of use: With a flie gas temperature of $11000 \mathrm{~F}$ and an excess air requirement of 908 , the amount of heat available for metal melting (including heat loot by radiation) is approximately 528 . 
TABLE 3-V. TYPICAL THERMAL PROPERTIES OF

REFRACTORY AND INSULATING CONCRETES

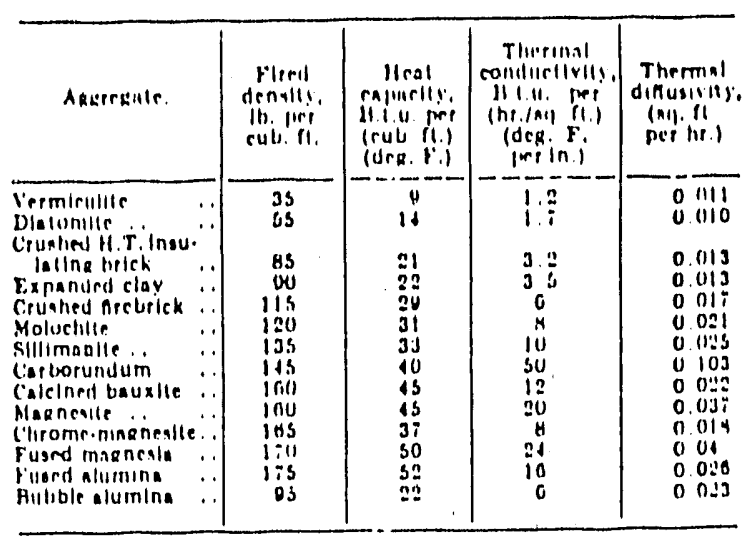

Example of use: Read " $K$ " (thermal conductivity) for type of lining in use.

PHYSICAL PROPERTIES*

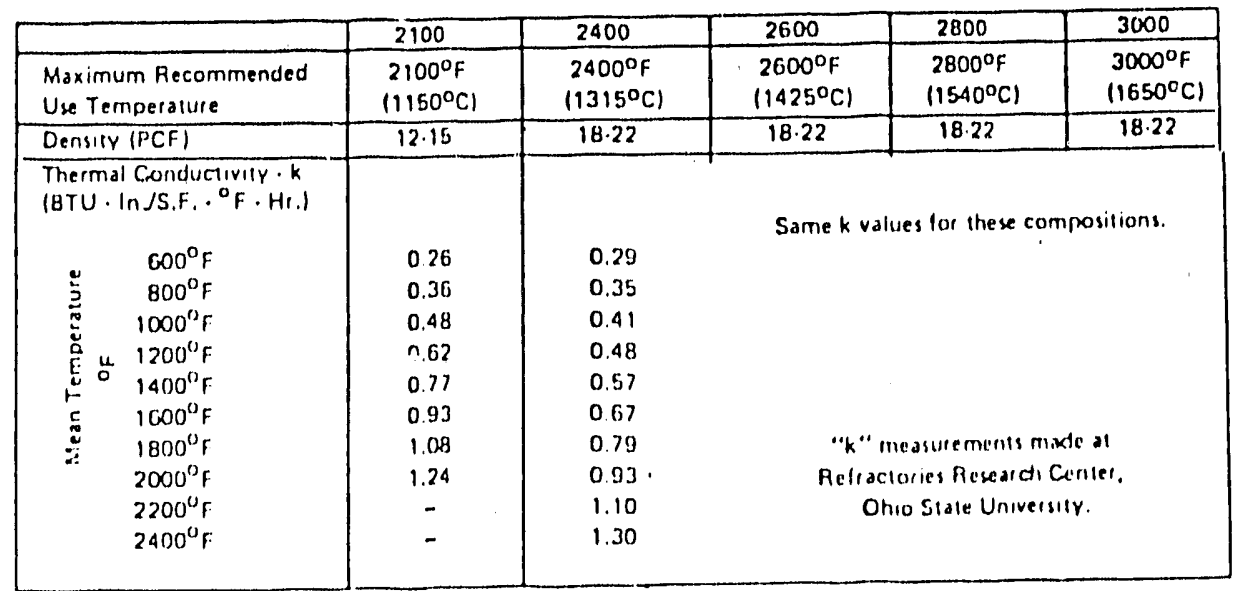

Ref. Industrial Insulations, Inc.

TABLE 3-VI. THERMAL PROPERTIES

Example of use:

Determine mean temperature from formula; $\frac{t_{1}-t_{2}}{2}=$ Mean wall temp.

Read " $K$ " thermal conductivity under maximum recommended use temperature. 


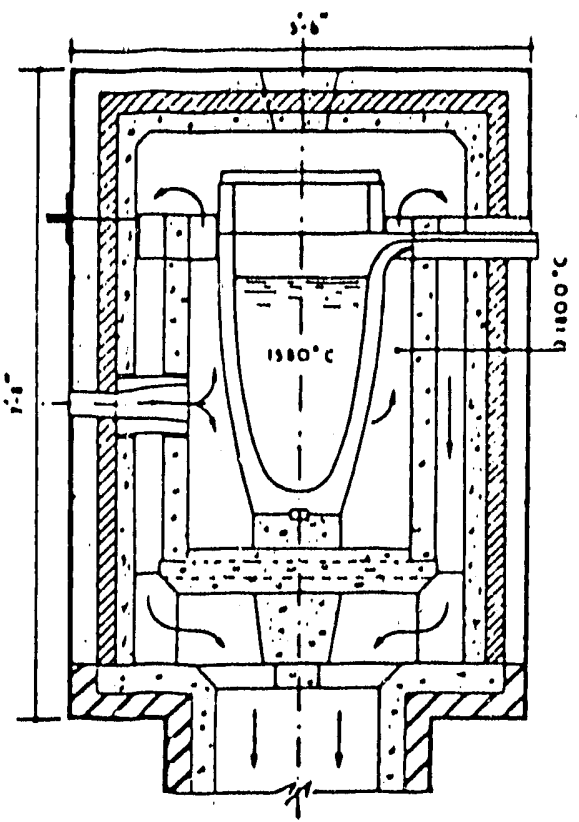

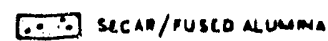

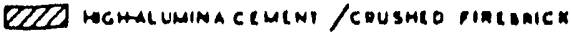

HICH-ALUMINA CIMINT/VIAOACULITE

EZ OIATOMITL onIC

FIGURE $3-11$

Composite refractory- and Insulatingconcrete lining of a propane-fired furnace

Example of $K$ values for above material

Fused alumina,

$\mathrm{K}=16$

Crushed Firebrick,

$K=6$

Vermiculite,

$\mathrm{K}=1.2$

Diatomite Brick,

$K=1.7$ 
TABLE 3-VII. HEAT STORAGE AND LOSSES BTU/SQ. FT.

\begin{tabular}{|c|c|c|c|c|c|c|c|}
\hline \multirow{3}{*}{ HinLL } & \multirow{3}{*}{ TYPE REFRACTORY } & \multicolumn{6}{|c|}{ HOT FACE TEIIPERATURE OF } \\
\hline & & \multicolumn{2}{|c|}{1,200} & \multicolumn{2}{|c|}{1.600} & \multicolumn{2}{|c|}{2,000} \\
\hline & & H. ST. & H.L. & H. ST. & H.L. & H. SY. & H.L. \\
\hline $9^{n}$ & $\begin{array}{l}\text { Composite } \\
2,000^{\circ} \text { insulation } \\
\text { and firebrick }\end{array}$ & 13,700 & 285 & 19.200 & 437 & 24,800 & 615 \\
\hline $13-1 / 2^{4}$ & $\begin{array}{l}\text { Comoosite } \\
2.000^{\circ} \text { insulation } \\
\text { and firebrick }\end{array}$ & 22,300 & 335 & 31.400 & 514 & 40,600 . & 718 \\
\hline $22-1 / 2^{\prime \prime}$ & $\begin{array}{l}\text { Composite } \\
2.000^{\circ} \text { insulation } \\
\text { and firebrick }\end{array}$ & 43,200 & 182 & 61,000 & 281 & 79,200 & 392 \\
\hline $5^{n}$ & Ceramic fiber & 842 & 208 & 1.170 & 432 & 1.490 & 672 \\
\hline
\end{tabular}

it. ST. - Heat Stored

H. L. - Heat Lost. BTU/Hr.

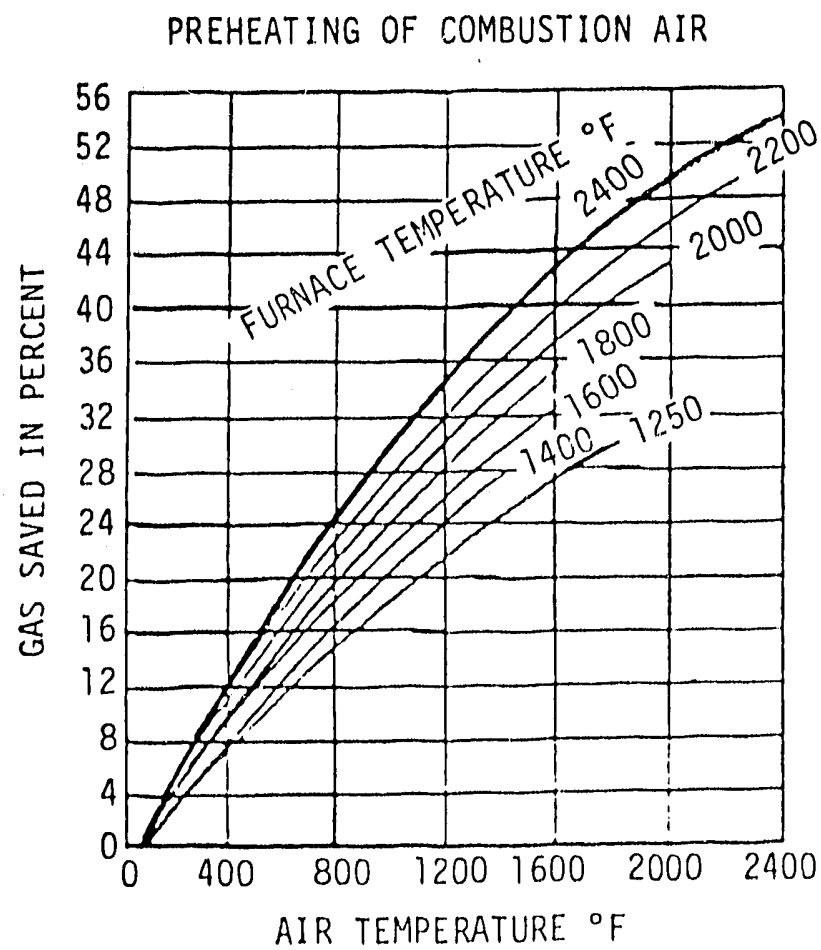

FIGURE NO. 3-12

Example of use: Read gas saved in percent against furnace temperature curve for combustion alr temperature obtained.

At $1600^{\circ} \mathrm{F}$ furnace temperature, and $1200^{\circ} \mathrm{F}$ air temperature, the gas saved is approximately 26 percent. 


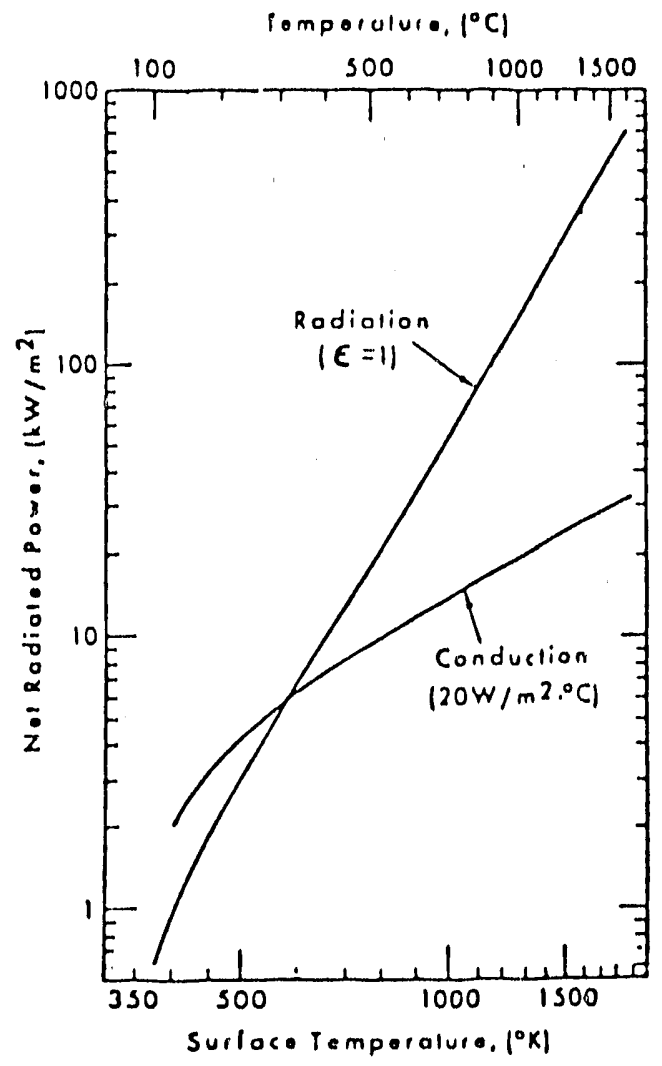

FIGURE 3-13

Example of use: Read net radiation $\left(\mathrm{kw} / \mathrm{m}^{2}\right)$ against surface temperature and radiation curve.

e.g. at $800^{\circ} \mathrm{C}$, radiated power 18 approx. $100 \mathrm{kw} / \mathrm{m}^{2}$. Where $800^{\circ} \mathrm{C}=1472^{\circ} \mathrm{F}$.

$100 \mathrm{kw} / \mathrm{m}^{2}=30,000 \mathrm{BTU} / \mathrm{sq}$. ft. 
Example: A cructble furnace melts 2,000 1bs. of aluminum per hour, flow meter readings indicate that $3,500 \mathrm{cu}$. tit. of gas per hour $\left(3.5 \times 10^{6}\right.$ BTU/hr.) is used.

Flue gas temperature was measured at $1150^{\circ} \mathrm{F}$ and the flue gas analysis showed a $\mathrm{CO}_{2}$ content of $5 \%$. Find present combistion efficlency and probable efficlency, by installation of a nozzle mix burner and fuel/air ratio controls, if $\mathrm{CO}_{2}$ content was corrected to $11 \%$ and excess air reduced to $10 \%$. For this example it has been assumed that furnaces are equipped with covers.

Present Combustion Effictency

Heat required to melt aluminum,

- Heat content of metal is 500 BTU/1b (Figure No. 3-8)

- Amount of metal heated per hour is 2,000 1b.

Therefore, heat to product is $500 \times 2000=1,000,000 \mathrm{BTU} / \mathrm{hr}$.

Heat lost to exhaust.

- From Figure No. $3-9$ with $5 \% \mathrm{CO}_{2}$ in flue gas the excess is approximately $130 \%$.

- From Figure No. 3-10 with a flue gas temperature of $1150^{\circ} \mathrm{F}$ and $130 \%$ excess air, the percent of gross fuel input avallable to do work (Including radiation 10sses) is approximately $40 \%$.

Therefore, of the 3,500,000 BTU/hr. energy input only $(3,500,000 \times$ $0.4) 1,400,000 \mathrm{BTU} / \mathrm{hr}$ (minus the radiation losses) is ut1lized.

\section{Probable Combustion Efflclency}

Heat lost of exhaust

- From Figure No. 3-9 with $11 \% \mathrm{CO}_{2}$ in flue gas the excess air is 10\% approximately.

- From Figure No. 3-10 with a flue gas temperature of $1.150^{\circ}$ and $10 \%$ excess air, the percent of gross fuel input avallable to do work (including radiation 10sses) is approximately $65 \%$.

Therefore, of the $3,500,000 \mathrm{BTU} / \mathrm{hr}$. energy input $(3,500,000 \times 0.65)$ $2,275,000 \mathrm{BTU} / \mathrm{hr}$. Is avallable for melting the metal. 
As previously stated the amount of heat required to melt $2,0001 \mathrm{bs}$. of aluminum is $1,000,000 \mathrm{BTU} / \mathrm{hr}$. Present combustion efficlency calculations show that $1,400,000 \mathrm{BTU} / \mathrm{hr}$. was avallable to melt the metal. Therefore: $1,400,000-1,000,000$ results in $400,000 \mathrm{BTU} / \mathrm{hr}$. being $108 \mathrm{t}$ by radiation effects. By 1ncreasing the avallable fuel to $65 \%$ it can be readlly seen that a smaller burner could be used to accomplish the same work.

$$
\frac{875,000 \mathrm{BTU} / \mathrm{hr} .}{350,000 \mathrm{BTU} / \mathrm{hr} \cdot} \times 100=25 \% \text { less fuel }
$$

Summary

\begin{tabular}{lrr}
\hline Item & Present Energy & Probable Eneigy \\
\hline Heat to product & $1,000,000 \mathrm{BTU} / \mathrm{hr}$. & $1,000,000 \mathrm{BTU} / \mathrm{hr}$. \\
Heat loss to Stack & $2,100,000 \mathrm{BTU} / \mathrm{hr} \cdot$ & $1,225,000 \mathrm{BTU} / \mathrm{hr}$. \\
Heat loss (Radiation) & $400,000 \mathrm{BTU} / \mathrm{hr} \cdot$ & $400,000 \mathrm{BTU} / \mathrm{hr}$. \\
\hline Gross Input & $3,500,000 \mathrm{BTU} / \mathrm{hr}$. & $2,625,000 \mathrm{BTU} / \mathrm{hr}$. \\
\hline
\end{tabular}

Process Energy Flow Diagrams

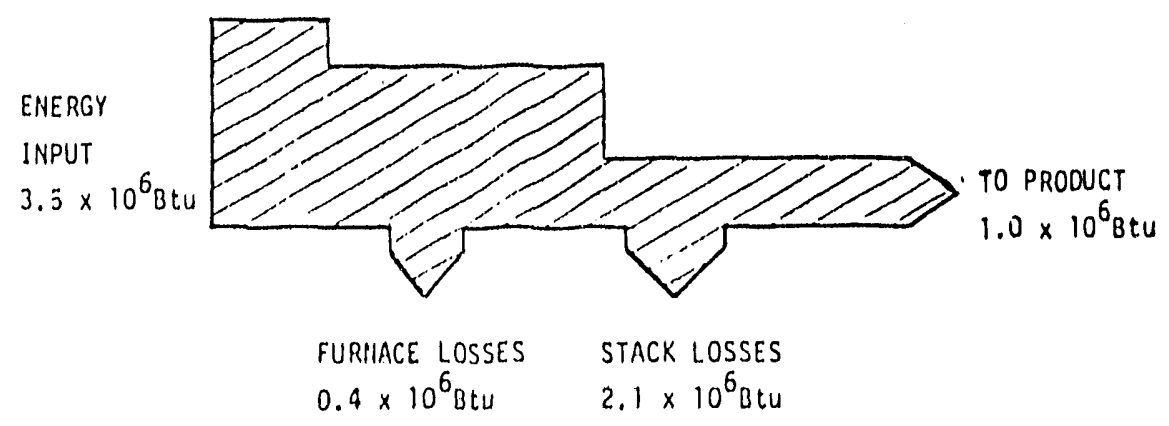

PRESEIIT CONOITION

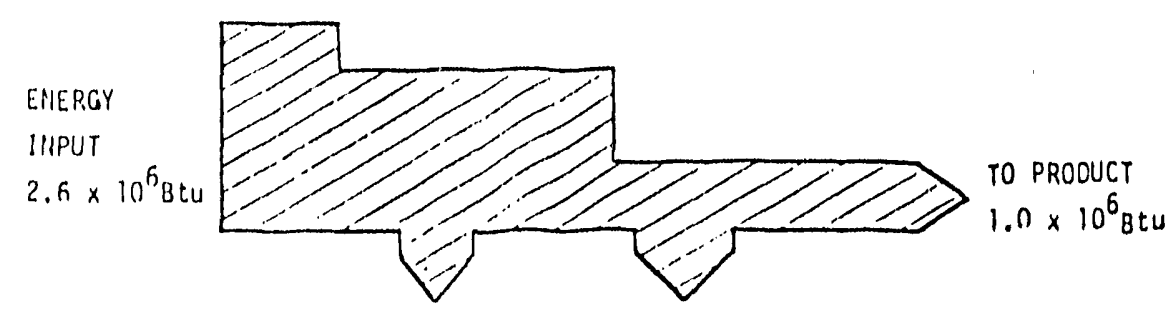

FURIACE LOSSES STACK LOSSES

$0.4 \times 10^{6} \mathrm{BtU} \quad 1.2 \times 10^{6} \mathrm{BtU}$

PROBABLE CONDITIO:1 

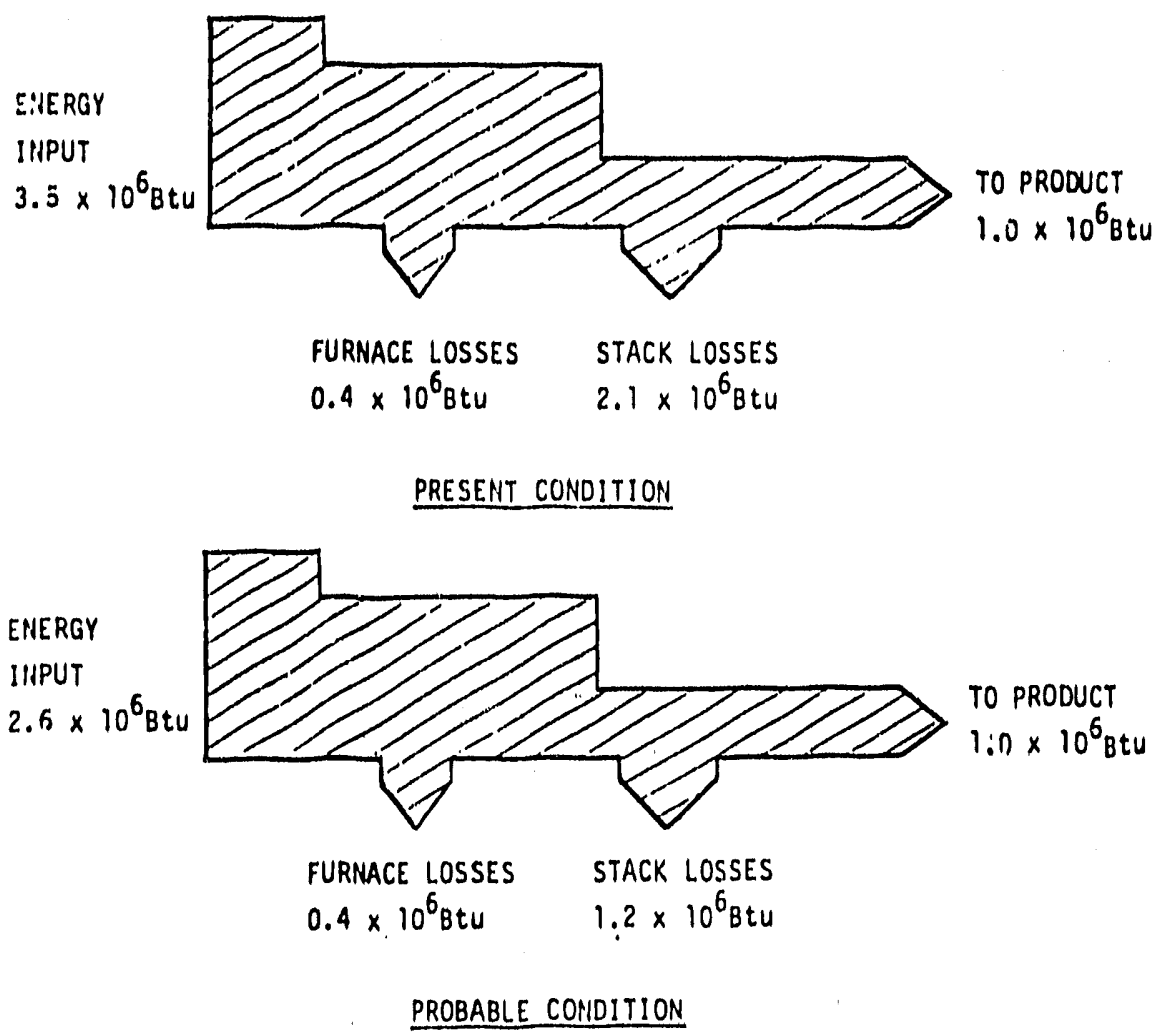

Yearly Energy Cost Savings

Assuming, using the above example, that the furnace melted 8 hours per day, 5 days per week, 50 weeks per year then the energy and cost savings would be:

$8 \times 5 \times 50 \times 875,000 \mathrm{BrU} / \mathrm{hr} .=1750 \times 10^{6} \mathrm{BTU}$ or 17500 therms/year, at $\$ 0.30$ per therm, J jarly savings would be $\underline{\$ 5,250}$

\section{COMBUSTION AIR PREHEATING}

For typlcal gas fired furnace whth flow rate of $3.5 \times 10^{6} \mathrm{BTU} / \mathrm{hr}$, improved efficlency can be attained by preheating the combustion air with the use of a hot gas recuperator. 
With Elue gas temperature of $1600^{\circ} \mathrm{F}$, If combustion alr is pre-heated to $1200^{\circ} \mathrm{F}$, energy savings of approx. $26 \%$ are avallable as obtained from Fig. 3-12. Thus heat savings can be calculated for the typical gas fired furnace as follows:

$2.625 \times 10^{6} \mathrm{BTU} / \mathrm{hr} \cdot \times 0.26=0.68 \times 10^{6} \mathrm{BTU} / \mathrm{hr}$.

Annual energy reduction based on 8 hours/day, 240 days per year is $0.68 \times 10^{6} \times 8 \times 240$ 100,000 BTU/therm

$\Rightarrow 13,100$ terms/yr. \& $\$ 0.30$ per therm, cost

reduction $=\# 3,930 /$ year

\begin{tabular}{lrr}
\hline Item & Present Energy & Probable Energy \\
\hline Heat to Melt & $1,000,000 \mathrm{BTU} / \mathrm{hr}$. & $1,000,000 \mathrm{BTU} / \mathrm{hr}$. \\
Stack Losses* & $1.225,000 \mathrm{BTU} / \mathrm{hr}$. & $545,000 \mathrm{BTU} / \mathrm{hr}$. \\
Radiant Los ses* & $400,000 \mathrm{BTU} / \mathrm{hr}$. & $400,000 \mathrm{BTU} / \mathrm{hr}$. \\
\hline Gross Input & $2,625,000 \mathrm{BTU} / \mathrm{hr}$. & $1,945,000 \mathrm{BTU} / \mathrm{hr}$. \\
\hline
\end{tabular}

* Stack and radiant losses from previous example after improvements

REFRACTORY MATERIALS - CRUCIBLE FURNACE

Samp1/a Calculation -

A cruitible furnace with composite refractory and insulating concrete lining is compared to same turnace with ceramic fiber sleeve insulating macertal. Diagram of typlcal furnace with composite ining is shown in Fig. it-11.

The heat joss through composite material is determined by calculathon of "Q".

$$
Q \text { per sq. t.t. } \Rightarrow \frac{t_{1}-t_{2}}{R_{1}+R_{2}} \text { etc. }
$$

Where $\quad t_{1}=$ Hot Face Wall Temperature.

$t_{2} \Rightarrow$ Cold Face Wall Temperature.

$\mathrm{R}^{2}:$ Resistance, which is the wall thickness divided by "K", the conductivity of the material. 
" $K$ " for various materials is obtalned from table of typlcal thermal properties (Table $3-V$ ). Thus $R_{1}+R_{2}$ etc. for various thicknesses is:

$$
\begin{array}{ll}
R 1=\frac{2}{16} \text { (fused alumina) } & =0.125 \\
R 2=\frac{3}{6} \quad \text { (crushed firebrick) } & =0.333 \\
R 3=\frac{1}{1.2} \text { (vermiculite) } & =0.833 \\
\text { Total } R_{1}+R_{2}+R_{3} & =\overline{1.291} \\
\text { Area of side walls est'mated to be } 110 \mathrm{sq} \cdot \mathrm{ft} . \\
\text { Thus heat } 10 \mathrm{ss} \text { through composite material }=\mathrm{Qa} \\
\therefore \text { Qa }=\frac{(3,000-100)}{1.291} \underline{110}=247,000 \mathrm{BTU} / \mathrm{hr} .
\end{array}
$$

NOTE: The above calculatio d demonstrates the methodology used for computing sample radiation losses. Actual radiation losses used throughout the preceding examplics is $400,000 \mathrm{BTU} / \mathrm{Hr}$.

Replace 6" composite material with 6" ceramic fiber sleeve of $3,000^{\circ} \mathrm{F}$ maximum use temperature. The calculation of mean temperature $=$

$$
\frac{t_{1}-t_{2}}{2}=\frac{3,000-100}{2}=1450^{\circ} \mathrm{F}
$$

$\mathrm{K}$ value for mean temperature of $1450^{\circ} \mathrm{F}$ (from Table 3-VI) is prorated between 0.57 and 0.67 to be 0.60

thus $R$ (ceramic fiber) $=\frac{6}{0.60}=10$

Thus heat loss through ceramic fiber sleeve $=\mathrm{Qb}$

$$
\therefore Q \mathrm{Qb}=\frac{(3,000-100) 110}{10}=31,900 \mathrm{BTU} / \mathrm{hr}
$$

Change in heat loss $Q \mathrm{a}-\mathrm{Qb}=247,000-31,900=215,100 \mathrm{BTU} / \mathrm{hr}$

Based on a melt program of 8 hours/day, 240 days per year, the annual gas usage reduction is as follows:

$$
\frac{215,100 \mathrm{BTU} / \mathrm{hr} \times 8 \times 240}{100,000 \mathrm{BTU} / \text { therm }} \times \$ 0.30=\$ 1,240 / \text { year } .
$$


If original energy input is $1.945 \times 10^{6} \mathrm{BTU} / \mathrm{hr}$, the furnace efficiency is improved from 51.4 per cent to approximately 57.8 percent, or $6.4 \%$ increase in efficlency.

Summary

\begin{tabular}{lrr}
\hline Item & Present Energy & Probable Energy \\
\hline Heat to Melt & $1,000,000 \mathrm{BTU} / \mathrm{hr}$. & $1,000,000 \mathrm{BTU} / \mathrm{hr}$. \\
Radiation Loss* & $400,000 \mathrm{BTU} / \mathrm{hr}$. & $185,000 \mathrm{BTU} / \mathrm{hr}$. \\
Radiant Losses* & $545,000 \mathrm{BTU} / \mathrm{hr}$. & $545,000 \mathrm{BTU} / \mathrm{hr}$. \\
\hline Gross Input & $1,945,000 \mathrm{BTU} / \mathrm{hr}$. & $1,730,000 \mathrm{BTU} / \mathrm{hr}$. \\
\hline $\begin{array}{l}\text { * Stack and radiant losses from previous example after improvements of } \\
\text { combustion equipment. }\end{array}$
\end{tabular}

TYPICAL ENERGY FLOW DIAGRAM

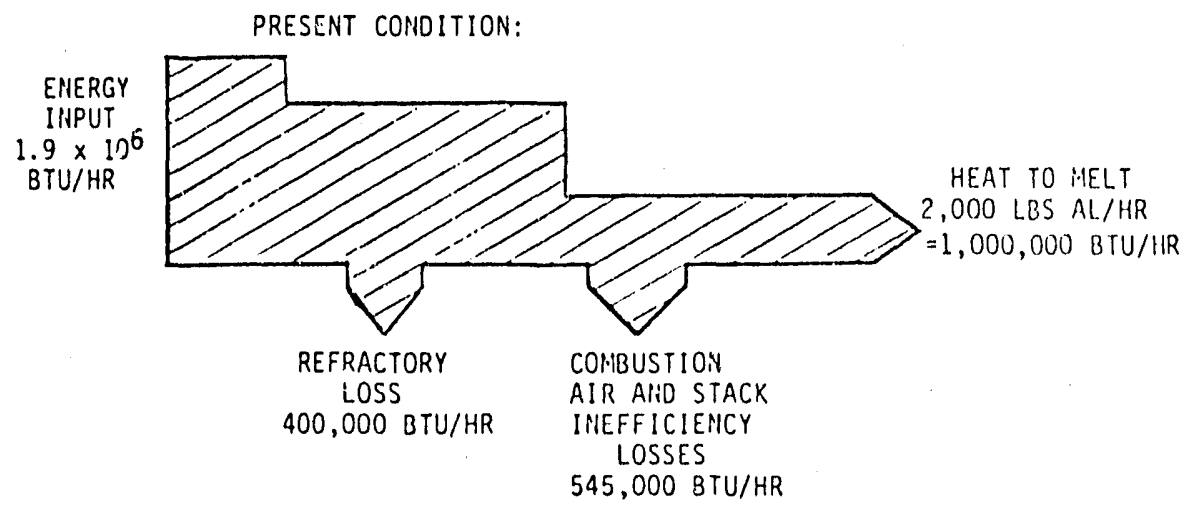

PROBABLE CONDITION:

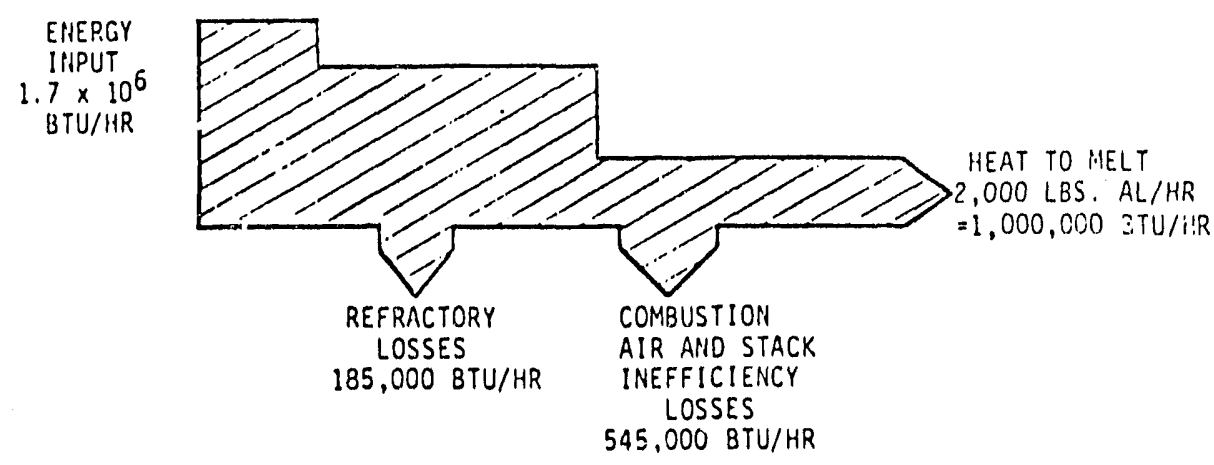




\section{FURNACE COVERS}

Ladle and furnace covers eliminate most of the radiation 108 which is the major area of energy loss from uncovered ladles and metal surfaces. Net radiated heat loss from a metal surface, emissivity, depends on the amount of slag. Emissivity of clean iron is relatively small but the thin slag layer usually present increases emissivity. Energy loss can be obtained by reference to $\mathrm{F} 1 \mathrm{~g} \cdot 3-13$ by reading net radlated power at metal temperature from the chart.

Example, at metal temperature of $800^{\circ} \mathrm{C}\left(1472^{\circ} \mathrm{F}\right)$, read for radiation at $E=1$, net radiated power $=100 \mathrm{kw} / \mathrm{m}^{2}\left(0.03 \times 10^{6} \mathrm{BTU} / \mathrm{sq} . \mathrm{ft}.\right)$

$$
\text { Where: } \begin{aligned}
1 \mathrm{~m}^{2} & =10.76 \mathrm{sq} \cdot \mathrm{ft} . \\
1 \mathrm{kw} & =3412 \mathrm{BTU} .
\end{aligned}
$$

Sample Calculation-

Consider a gas fired furnace holding aluminum at $1400^{\circ} \mathrm{F}$ with dip well area $4 \mathrm{sq}$. ft. without a cover and calculate the energy savings with a ceramic fiber cover in place.

Radiation losses, at $1400^{\circ} \mathrm{F}\left(760^{\circ} \mathrm{C}\right)$ from $\mathrm{Fig} \cdot 3-13=60 \mathrm{kw} / \mathrm{m}^{2}$

$=19,000 \mathrm{BTU} / \mathrm{sq} \cdot \mathrm{ft}$.

Thus $4 \mathrm{sq} \cdot \mathrm{ft} \cdot \mathrm{x} 19,000 \mathrm{BTU}=76,000 \mathrm{BTU} / \mathrm{hr}$.

Heat loss from dip well with cover, based on thickness of two inches for ceramic fiber cover, is:

$$
Q=\frac{t_{1}-t_{2}}{R_{1}+R_{2}} \text { etc. }
$$

where $t_{1}=$ hot face temp. $1400^{\circ} \mathrm{F}$.

$$
\begin{aligned}
\mathrm{t}_{2}= & \text { cold face temp. } 200^{\circ} \mathrm{F} . \\
\mathrm{R}^{2}= & \text { Resistance which is the thickness of the cover divided } \\
& \text { by the conductivity } \mathrm{K} \text {. }
\end{aligned}
$$

$K$ for cover material can be obtained from Table 3-V where mean temperature of the material is given by

Mean temp. $=\frac{t_{1}-t_{2}}{2}=\frac{1400-200}{2}=600 \mathrm{~F}$

Thus $\mathrm{K}$ from Table $3-\mathrm{V}$ at $600^{\circ} \mathrm{F}=0.26$ (BTU/sq. ft. per ins $-\mathrm{O}_{\mathrm{F} / \mathrm{hr} \text {.) }}$

$$
\left.\therefore Q=\frac{(1400-200)}{2 / 0.26} 4 \mathrm{sq} \cdot \mathrm{ft} \cdot=\frac{4800}{7.7}=600 \mathrm{BTU} / \mathrm{hr} .\right)
$$


Savings in energy 10ss $=76,000-600=75,400 \mathrm{BTU} / \mathrm{hr}$.

With cover in place during 16 hours holding perlod per day, the reduction in energy for 240 days per year is:

$75,400 \times 16 \times 240=289 \times 10^{6}$ BTU year @ $\$ 0.30$ per therm, the cost savings is:

$$
\frac{289 \times 10^{6} \times 0.3}{100,000}=\$ 870 \text { per year }
$$

$\underline{\text { Summary }}$

\begin{tabular}{lrr}
\hline Item & Present Energy & Probable Energy \\
\hline Heat to Melt & $1,000,000 \mathrm{BTU} / \mathrm{hr}$. & $1,000,000 \mathrm{BTU} / \mathrm{hr}$. \\
Radiation Loss* & $185,000 \mathrm{BTU} / \mathrm{hr}$. & $109,600 \mathrm{BTU} / \mathrm{hr}$. \\
Radiant Losses* & $545,000 \mathrm{BTU} / \mathrm{hr}$. & $545,000 \mathrm{BTU} / \mathrm{hr}$. \\
\hline Gross Input & $1,730,000 \mathrm{BTU} / \mathrm{hr}$. & $1,654,600 \mathrm{BTU} / \mathrm{hr}$. \\
\hline
\end{tabular}

* Stack and radiant losses from previous example for present conditions after improvements.

\section{PRESEIT COMOITION -}

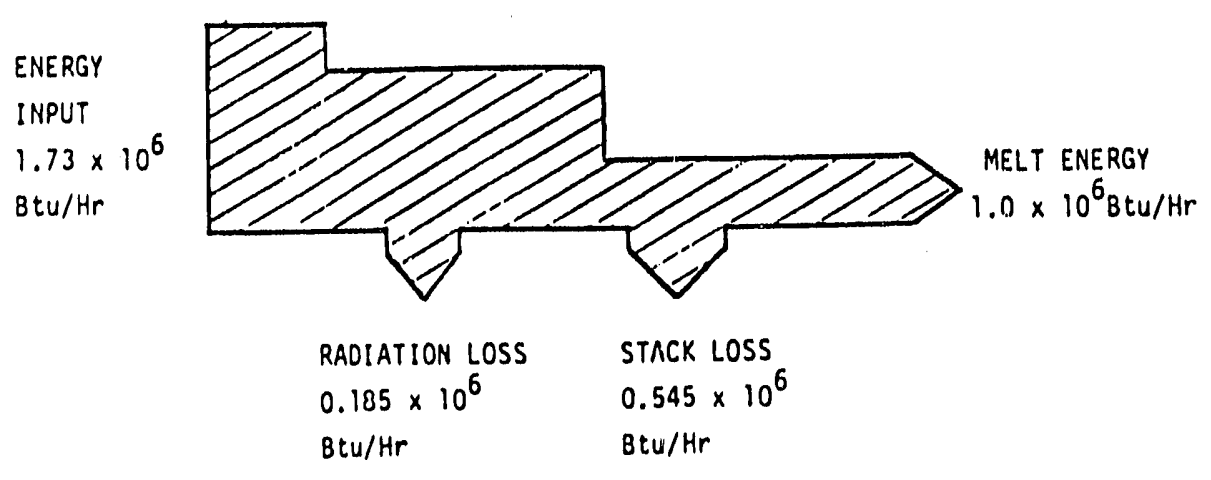

PROBABLE CONOITION -

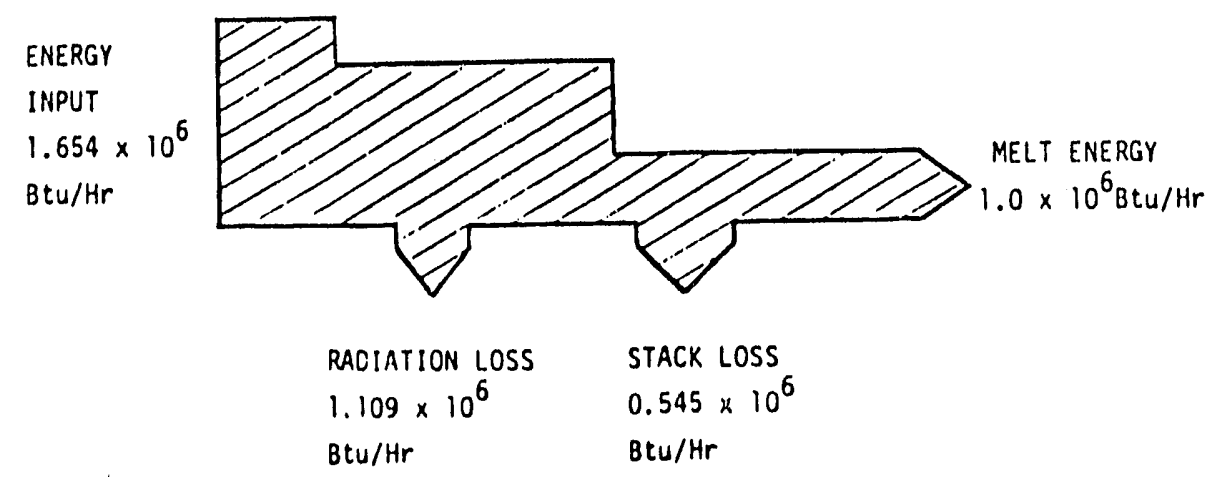


The following table sumarizes the probable cost and energy savings by carrying out all of the possible improvements prevlously covered in the examples.

Summary (Energy and Cost Savings)

\begin{tabular}{|c|c|c|c|c|}
\hline Item & $\begin{array}{l}\text { BTU/hr. } \\
\text { Reduction }\end{array}$ & $\begin{array}{l}\text { Efficiency } \\
\text { Percent } \\
\text { Increase }\end{array}$ & $\begin{array}{l}\text { Annual } \\
\text { Gas } \\
\text { Therms. }\end{array}$ & $\begin{array}{l}\text { Savings } \\
\text { Cost } \\
\text { s }\end{array}$ \\
\hline Combustion Efficiency & 875,000 & $25.0 \%$ & 17500 & 5250 \\
\hline Preheat Comb. Air & 680,000 & $26.0 \%$ & 13100 & 3930 \\
\hline Refractory Upgrade & 215,000 & $6.4 \%$ & 4130 & 1240 \\
\hline Furnace Covers & 75,000 & $2.6 \%$ & 2900 & 870 \\
\hline Total & $1,845,000$ & 31.8 & 37,630 & $\$ 11,290$ \\
\hline
\end{tabular}

$$
\begin{aligned}
& \text { Overall Thermal Efficiency }=\frac{1.0 \times 10^{6}}{(3.5-1.845) 10^{6} \times 100=60.4 \%} \\
& \text { Present Efflciency (Approximate) } \\
& =28.6 \% \\
& \text { Increased Efficlency }=60.4-28.6 \\
& -31.8 \% \\
& \text { Percent Energy Saved }=\frac{1,845,000}{3,500,000} \\
& -53 \%
\end{aligned}
$$

\section{REVERBERATORY FURNACES}

Energy savings and efficlency improvements can be developed for reverberatory furnaces. For combustion efficlency and burner preheating the previous examples are repeated and applled to reverberatory furnace summary analysis. 
REFRACTORY MATERIALS - REVERBERATORY FURNACES

Sample Calculation -

Assume a reverberatory furnace melts $2,000 \mathrm{lbs}$ of aluminum per hour. The area of refractory below metal is $40 \mathrm{sq}$. ft. and the area of refractory above metal is $40 \mathrm{sq}$. ft. Thlckness of refractory 186 Inches. Metal is at $1380^{\circ} \mathrm{F}$ and combustion gas temperature above the metal is $3000^{\circ} \mathrm{F}$. To find heat loss with conventional refractory, the thermal conductivity $k$ for the material is determined from Table $3-V$ to be 6 $\mathrm{BTU} / \mathrm{hr}$. per sq. ft. (deg. F per inch.) for crushed flrebrick.

Heat loss $Q=\frac{t_{1}-t_{2}}{R 1+F_{2}}$ etc.

Where $\quad t_{1}=$ Hot Face Wall Temperature.

$t_{2}=$ Cold Face Wall Temperature.

$\mathrm{R}^{2}$ = Resistance, which is the wall thickness of the lining divided by the conductivity of the material K.

Mean temperature $\frac{t_{1}-t_{2}}{2}$ is required to select $k$

Thus the mean temperature for area above the metal, based on a

combustion gas temperature of $3000^{\circ} \mathrm{F}=\frac{3000-100}{2}=1450^{\circ} \mathrm{F}$

Mean temperature for area below the metal $=\frac{1380-100}{2}=690^{\circ} \mathrm{F}$

$\therefore Q_{a}\left(\right.$ above the meta1) $=\frac{3000-100}{6 / 6}=2900 \mathrm{BTU} / \mathrm{Hr} / \mathrm{Sq} \cdot \mathrm{Ft}$.

$=2900 \times 40=116,000 \mathrm{BTU} / \mathrm{hr}$.

$\therefore Q b\left(\right.$ below the metal) $=\frac{1380-100}{6 / 6}=\frac{1280}{1}=1280 \mathrm{BTU} / \mathrm{hr} / \mathrm{sq} / \mathrm{ft}$.

$=1280 \times 40=51,200 \mathrm{BTU} / \mathrm{hr}$.

$\therefore$ Total heat loss through the refractory walls

$=Q a+Q b=116,000+51,200=167,200 \mathrm{BTU} / \mathrm{hr}$. 
To find the heat 10 ss with ceramic lining used for insulation between the refractory and the outer shel1, the added $R$, restatance, must be calculated.

The thermal conductivity $K$ for ceramlc fiber 18 determined from Table 3-V for 1 inch thick matertal to be $0.26 \mathrm{BTU} / \mathrm{hr}$. per sq. It. (deg. F per inch.)

Note - Mean temperature assumed between refractory and she11, $t=200^{\circ} \mathrm{F}$.

$\therefore \quad$ New heat 10ss Qa $+Q b=\frac{\left(t_{1 a}-\frac{\left.t_{2}\right) 40}{6 / 6}+\frac{\left(t_{1 b}-t_{2}\right) 40}{6 / 0.26}+1 / 0.26\right.}{6 / 6+1 / 0}$

$=\frac{(3000-100) 40}{1+3.84}=\frac{(1380-100) 40}{1+3.84}=23,970+10,600$

$=34,570 \mathrm{BTU} / \mathrm{hr}$.

Change in heat loss through 1 ining by adding 1 inch of ceramic fiber Insulation $=167,200-34,570=132,630 \mathrm{BTU} / \mathrm{hr}$. reduction, equivalent to $79.3 \%$ savings.

Based on a melt program of 8 hours per day, 240 days per year, the annual gas cost reduction $1 \mathrm{~s}$ as follows:

$$
\frac{132,600 \mathrm{BTU} / \mathrm{hr} \cdot \times 8 \times 240}{100,000 \mathrm{BTU} / \text { therm }} \times \$ 0.30=\$ 760
$$

Summary

\begin{tabular}{lrr}
\hline Item & Present Energy & Probable Energy \\
\hline Heat to Melt & $1,000,000 \mathrm{BTU} / \mathrm{hr}$. & $1,000,000 \mathrm{BTU} / \mathrm{hr}$. \\
Radtation Losses* & $250,000 \mathrm{BTU} / \mathrm{hr}$. & $117,000 \mathrm{BTU} / \mathrm{hr}$. \\
$\begin{array}{l}\text { Combustion and } \\
\text { Stack Losse } *\end{array}$ & $2,045,000 \mathrm{BTU} / \mathrm{hr}$. & $2,045,000 \mathrm{BTU} / \mathrm{hr}$. \\
\hline Gross Input & $3,295,000 \mathrm{BTU} / \mathrm{hr}$. & $3,162,000 \mathrm{BTH}, \mathrm{hr}$.
\end{tabular}

* Combustion and stack losses from previous example after Improvements are 11sted in this case for present energy use. 


\section{Energy flow dlagrams for all improvements by progression from original condition to ultimate condition are as follows:}

\section{Energy Flow Dlagrams - Reverberatory Furnace Example}

ORIGINAL CONDITION:

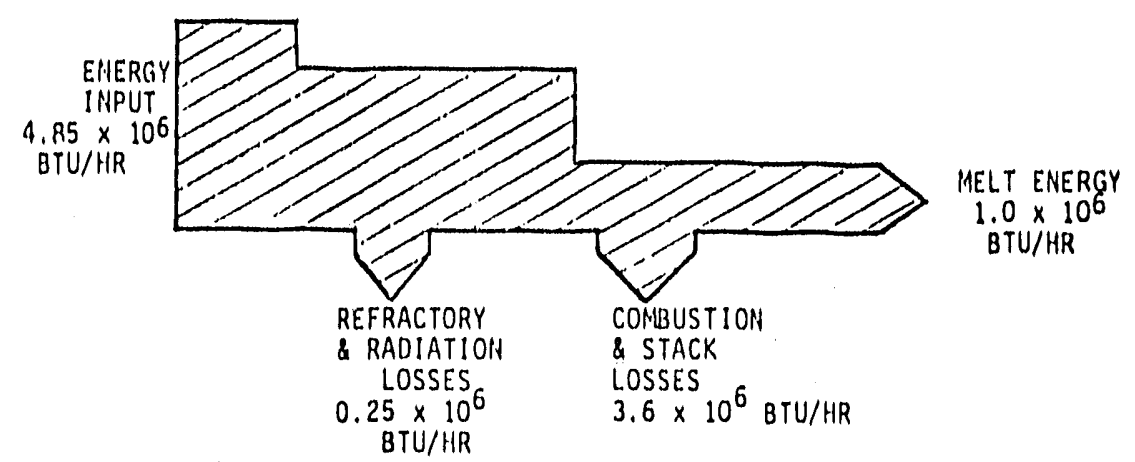

COMBUSTION IMPROVEMENT \& BURNER AIR PRE-HEAT

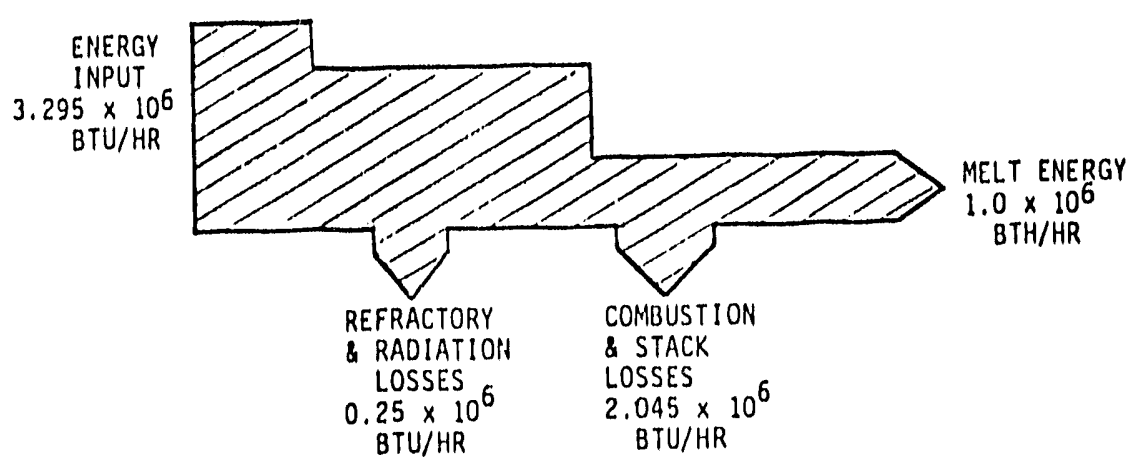

REFRACTORY \& METAL COVERS IMPROVEMENTS

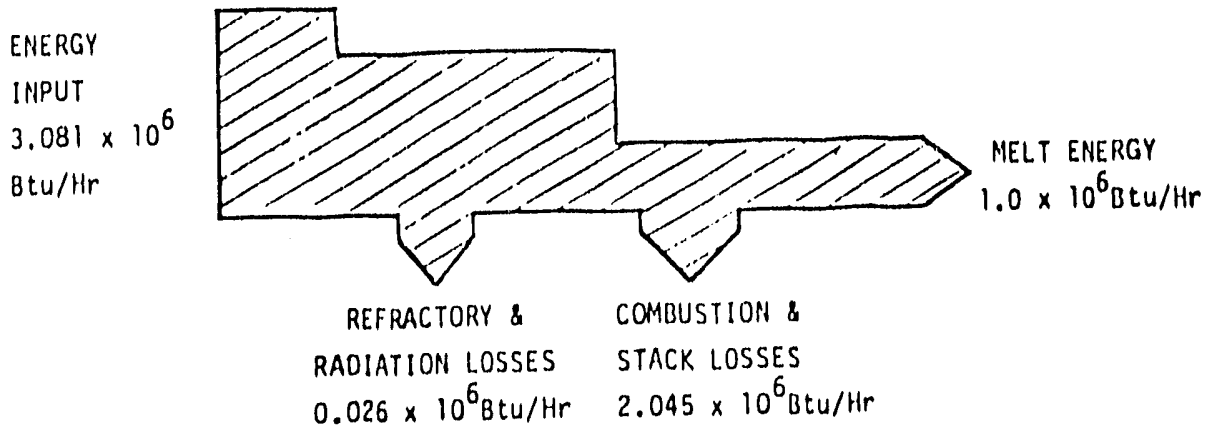


The following table summarizes the probable cost and energy saving avallable by carrying out all of the possible improvements in common with the cructble furnace per previous examples.

TABLE 3 - VIII. SUMMARY (ENERGY AN COST SAVINGS)

\begin{tabular}{|l|c|c|c|c|}
\hline \multicolumn{1}{|c|}{ ITEM } & $\begin{array}{c}\text { BTU/HR } \\
\text { REDUCTION }\end{array}$ & $\begin{array}{c}\% \text { ENERGY } \\
\text { SAVING }\end{array}$ & $\begin{array}{c}\text { ANNUAL } \\
\text { GAS THERMS }\end{array}$ & \multicolumn{1}{c|}{ SAVINGS } \\
COST $\$$
\end{tabular}

Overall percent energy reduction $=\frac{1,762,000}{4,850.000} \quad=36.3 \%$

Overa11 thermal efficiency $=\frac{1.0 \times 10^{6} \times 100}{\left(4.85-1.762 \times 10^{6}\right)}=32.3 \%$

Present efficiency (approximate) $\quad=20.6 \%$

Increased efficlency $=32.3-20.6=11.7 \%$ 
1. Replace existing burner system with a combination nozzle mix burner system-recuperator package with completely pre-wired control system Equipment Cost

$\$ 30,000.00 \quad 30,000.00$

2. Replace conventional refractory lining with ceramic fiber materlal

$\$ 2,000.00 \quad 500.00$

3. Metal covers in ceramic fiber material

$\$ \quad 200.00 \quad 200.00$

4. Labor to install Item 1

$\$ 17,000.00$

$17,000.00$

5. Engineering Costs

$\$ \quad 5,000.00 \quad 5,000.00$

TOTAL

$\$ 45,000.00 \quad 43,000.00$

Payback period

$=\frac{\text { Capital Investment }}{\text { Energy Savings } \$ / Y R}=$ Years

Therefore payback period (present day costs)

Cructble Furnace

Reverberatory Furnace $=\frac{45,000}{11,290}=3.98$ years

$=\frac{43,000}{10,850}=3.98$ years

NOTE: The above costs are for example only, actual equipment costs are to be obtalned for specific furnace 1 tem as part of normal engineering procedure. Labor costs for lining installations are assumed to be covered by normal maintenance expense budget. 


\section{HEAT TREATING}

\section{General Considerations}

Th1s section, dealing with the energy savings obtainable in the Heat Treat Furnace operation, will concentrate generally on the major areas for energy savings attributed to:

- Process operation and control

- Refractory materlals

- Combustion equipment

- Heat recuperation

Formulas, calculations, and graphs have been simplified with the Scope of the project to reflect constant conditions during the process.

To Investigate any process in depth it is essential to establish parameters, circulate the data and plot results on a continuous basis to establish the limits of the operation and equipment, and identify any trends.

The work sheet 1ists the expected parameters for furnace she11, blower, burner and ancillary equipment, and operational data to complete a "one shot" energy audit and constitute a base for any future improvements. A tape measure, thermometer, flue gas analyzer and flow meters w111 be the tools needed. 
FIGURE 3-14. HEAT TREAT DATA INPUT

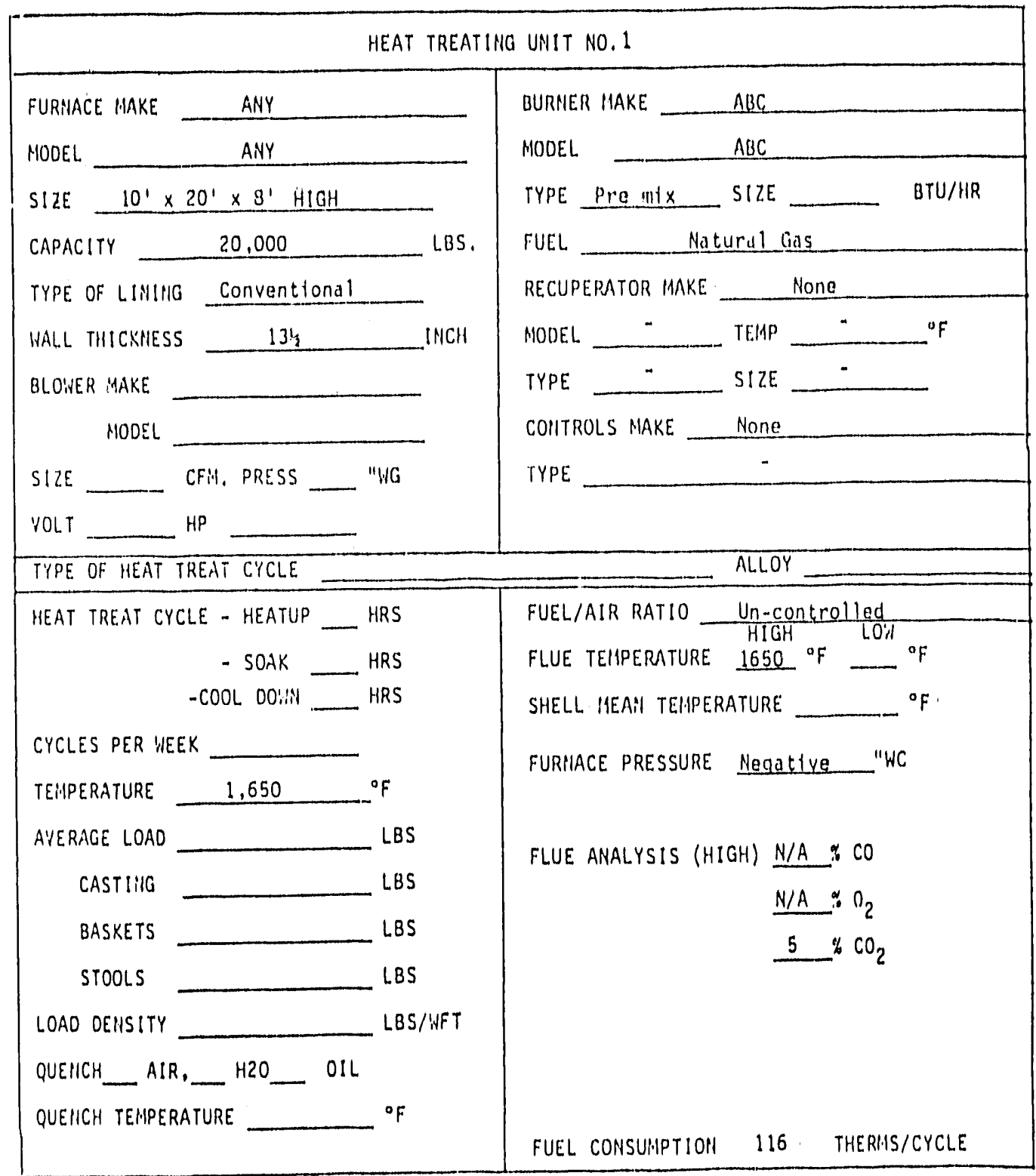

\section{MISCELLANEOUS}

WALL AREA 880 SO.FT.

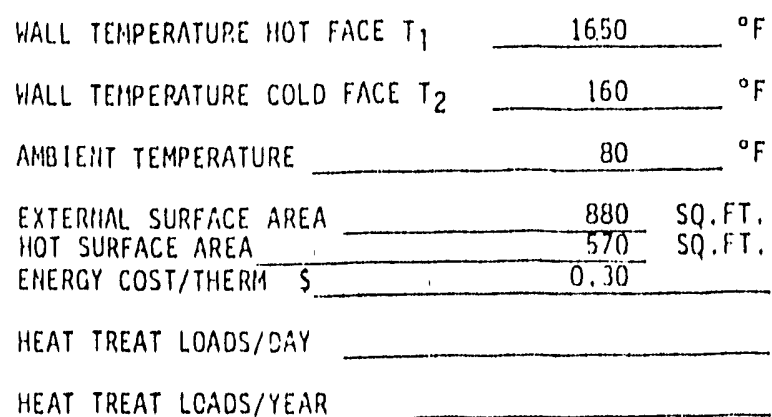

Note: Data Recorded is only that needed to perform sample calculations. 
TABLE 3-IX

APPROXINATE THERMAL CONDUCTIVITIES

OF FIRECLAY BRICK

Btu per Hour, per Square Foot, per Degree F. Temperature Dffference, for One-Inch Thickness

\begin{tabular}{|c|c|c|c|c|c|c|c|c|c|c|c|c|c|c|c|}
\hline \multirow{2}{*}{$\begin{array}{l}\text { Kind of } \\
\text { Brick }\end{array}$} & \multirow{2}{*}{$\begin{array}{l}\text { Den- } \\
\text { sityt }\end{array}$} & \multicolumn{14}{|c|}{ Mean Conductivity at $T^{\circ} \mathrm{F}$. } \\
\hline & & 200 & 400 & 600 & 800 & 1000 & 1200 & 1400 & 1600 & 1800 & 2000 & 2200 & 2400 & 2600 & 2800 \\
\hline & 147 & 9.7 & 9.7 & 9.7 & 9.8 & 9.9 & 10.0 & 10.2 & 10.3 & 10.5 & 10.7 & 10.9 & 11.1 & 11.3 & \\
\hline & 146 & 8.7 & 8.8 & 9.0 & 9.1 & 9.3 & 9.4 & 9.6 & 9.7 & 9.9 & 10.0 & 10.2 & 10.4 & 10.5 & \\
\hline & 136 & 8.4 & 8.5 & 8.7 & 8.8 & 9.0 & 9.2 & 9,3 & 9,5 & 9.6 & $9.8^{\prime}$ & 9.9 & 10.1 & $\ldots$ & \\
\hline & 127 & 7.1 & 7.3 & 7.4 & 7.6 & 7.8 & 8.0 & 8.1 & 8.3 & 8.5 & 8.7 & 8.8 & 9.0 & $\cdots$ & \\
\hline & 125 & 5.8 & 6.2 & 6.5 & 6.9 & 7.3 & 7.6 & 8,0 & 8,3 & 8.7 & 9.0 & 9.4 & 9.8 & & \\
\hline
\end{tabular}
*pounds per cubte foot.

NOTE: For brick of the same type, class, composition, and burn, the conductivities are approximately proportional to the bulk densities (weights in pounds per cublc foot).

TABLE 3-X

APPROXIMATE TILERIAL CONDUCTIVITIES

OF INSUI.ATIHG FIREBRICK

Btu per Hour, per Square Foot, per Degree F. Temperature Difference, for One-Inch' Thicknoss

\begin{tabular}{|c|c|c|c|c|c|c|c|c|c|c|c|c|c|c|}
\hline \multirow{2}{*}{$\begin{array}{l}\text { Den- } \\
\text { sitink }\end{array}$} & \multicolumn{14}{|c|}{ Thermal Conductivity at $T^{\circ} \mathrm{F}$} \\
\hline & 200 & 400 & 600 & 800 & 1000 & 1200 & 1400 & 1600 & 1800 & 2000 & 2200 & 2400 & 2600 & 2800 \\
\hline 36 & 1.06 & 1.20 & 1.31 & 1.48 & 1.63 & 1.77 & 1.91 & 2.05 & 2.19 & $\cdots$ & $\ldots$ & $\ldots$ & $\ldots$ & $\cdots$ \\
\hline 38 & 1.26 & 1.10 & 1.54 & 1.63 & 1.83 & 1.97 & 2.11 & 2.2 .5 & 2.40 & $\cdots$ & $\ldots$ & $\cdots$ & $\cdots$ & $\cdots$ \\
\hline 46 & 1.44 & 1.59 & 1.75 & 1.91 & $? .06$ & 2.22 & 2.38 & 2.53 & 2.69 & 2.85 & 3,00 & $\ldots$ & $\ldots$ & $\cdots$ \\
\hline 31 & 0.78 & 0.30 & 0.94 & 1.02 & 1.09 & 1.17 & 1.25 & 1.33 & 1.41 & 1.48 & 1.56 & $\ldots$ & $\ldots$ & $\ldots$ \\
\hline 49 & 1.83 & 1.98 & 2.13 & 2.28 & 2.13 & 2.58 & 2.73 & 2.883 & 3.03 & 3.18 & 3.33 & 3.48 & $\ldots$ & $\ldots$ \\
\hline 56 & 1.95 & 2.10 & 2.25 & 2.40 & 2.55 & 2.70 & 2.85 & 3.00 & 3.15 & 3.30 & 3.45 & 3.60 & 3.75 & 3.90 \\
\hline 60 & 2.20 & 2.35 & 2.50 & 2.65 & 2.80 & 2.95 & 3.10 & 3.25 & 3.40 & 3.55 & 3.70 & 3.85 & 1.00 & 4.15 \\
\hline
\end{tabular}


FIGURE 3-15. THERMAL CONDUCTIVITY OF CERAMIC FIBER INSULATION

Therinal Conducllwlly we Alean 'Tenmeralure (per As'TM C.1771"*

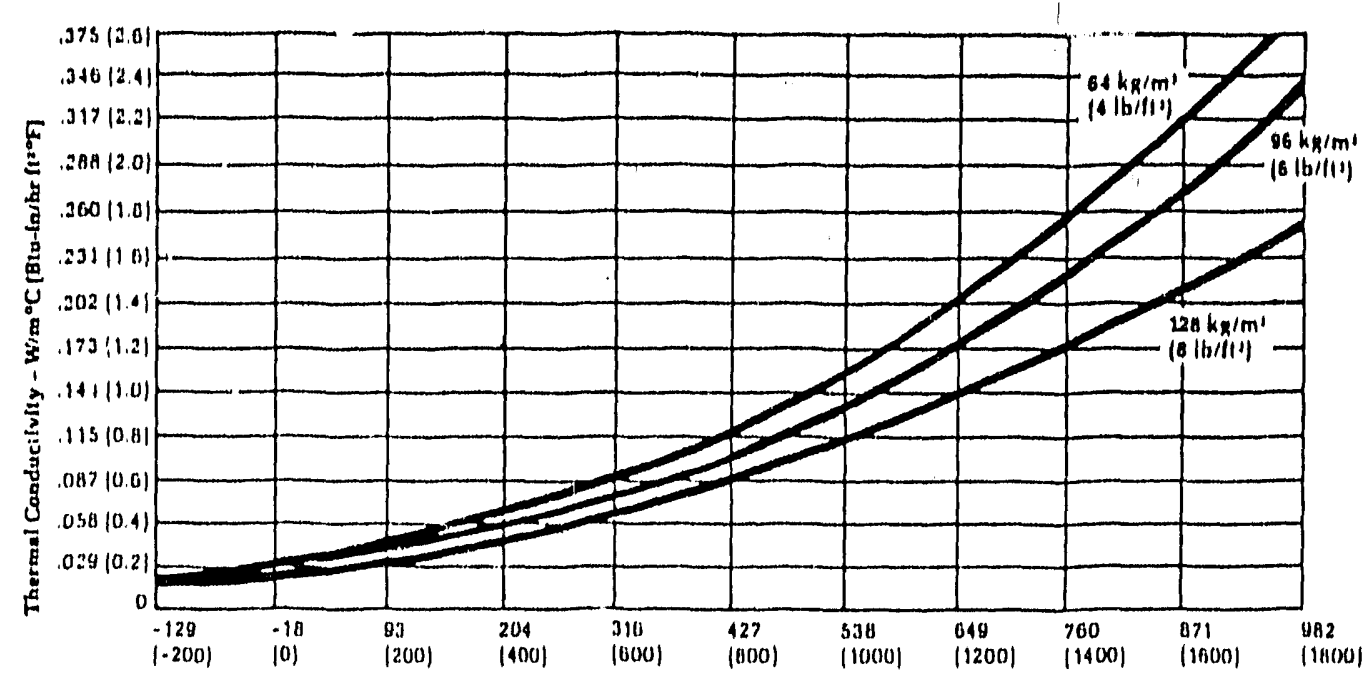

Mean Temperulure ${ }^{\circ} \mathrm{C} /{ }^{\circ} \mathrm{F}$

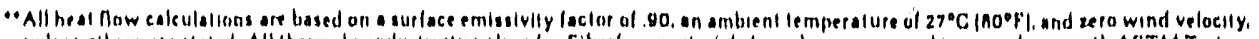

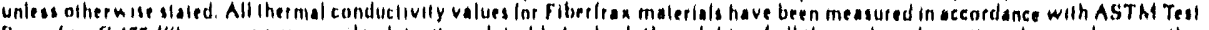

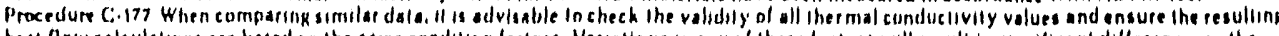

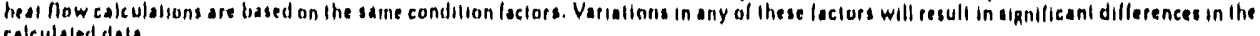
calculaled dala.

Heat atorage and $1088 \theta 8$ can be approximated baged on the following

Table $3-X I$.

TABLE 3-XI. HEAT STORE AND LOSSES BTU/SQ. FT.

\begin{tabular}{|c|c|c|c|c|c|c|c|}
\hline \multirow{3}{*}{$\begin{array}{c}\text { HALL } \\
\text { THICKAESS }\end{array}$} & \multirow{3}{*}{ TYPE REFRACTORY } & \multicolumn{6}{|c|}{ HOT FACT TELPERATURE OF } \\
\hline & & \multicolumn{2}{|c|}{1,200} & \multicolumn{2}{|c|}{1,600} & \multicolumn{2}{|c|}{2,000} \\
\hline & & H. ST. & II.L. & H. ST. & H.L. & H. ST. & H.L. \\
\hline $9^{\prime \prime}$ & $\begin{array}{l}\text { Connosite } \\
2,000^{\circ} \text { Insulation } \\
\text { and firebick }\end{array}$ & 13,700 & 285 & 19,200 & 437 & 24,800 & 615 \\
\hline $13-1 / 21$ & $\begin{array}{l}\text { Composite } \\
2,000^{\circ} \text { insulation } \\
\text { and firebrick }\end{array}$ & 22,300 & 335 & 31,400 & 514 & 40,600 & 718 \\
\hline $22-1 / 2^{\prime \prime}$ & $\begin{array}{l}\text { Compos t te } \\
2,000^{\circ} \text { insulation } \\
\text { and firebrick }\end{array}$ & 43,200 & 182 & 61,000 & 281 & 79,200 & 392 \\
\hline $6 "$ & Ceramic fiber & 842 & 208 & 1,170 & 432 & 1,490 & 672 \\
\hline
\end{tabular}

H. ST. - Heat Stored

H. L. - Heat Lost Btu/hr 


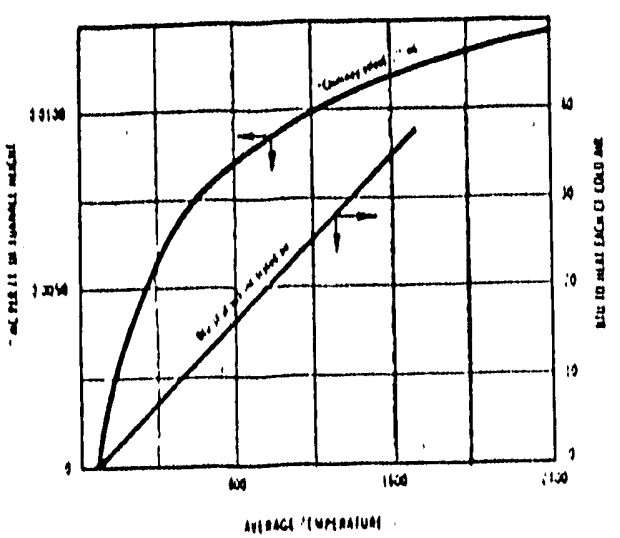

FIGURE 3-18A

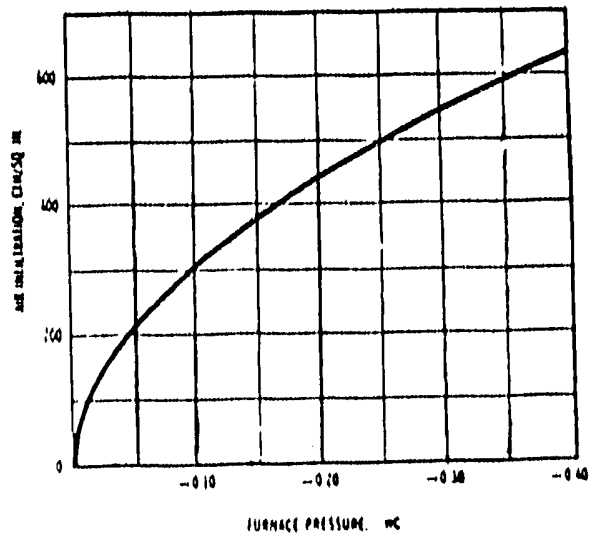

FIGURE $3-18 B$

Courtegy of American Gas Association

Above table to be ured for calculating air infiltration through oraoks.

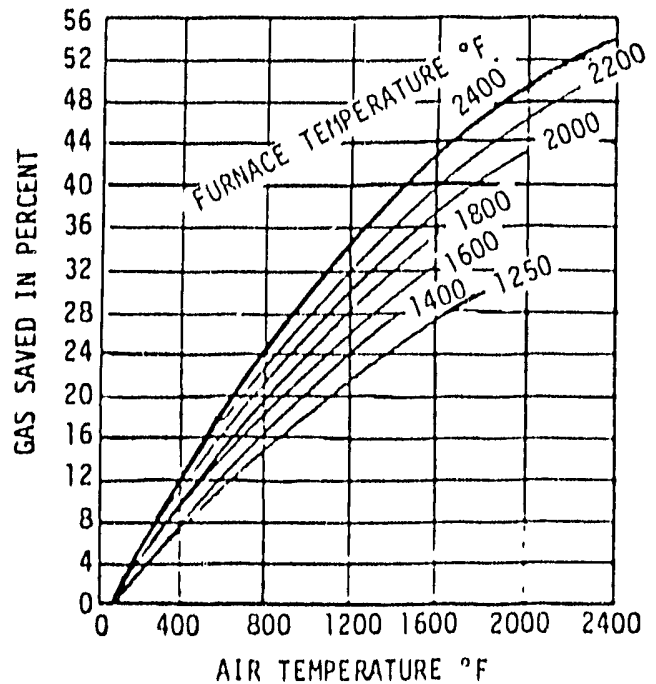

FIGURE 3-19. PREHEATING OF COMBUSTION AIR*

* From AGa Catalog 


\section{SAMPLE CALCULATIONS}

Upgrading Furnace Linings

Heat 108 s through various refractory linings can be calculated by the use of the following mathematical formula:

HEAT LOSS " $Q$ " $=\frac{T_{1}-T_{2}}{R_{1}+R_{2}}$ etc.

WHERE :

$$
\begin{array}{ll}
t_{1}= & \text { Hot face wall temperature } \\
t_{2}= & \text { Cold face wall temperature } \\
R \quad=\quad \begin{array}{l}
\text { Resigtance, which is the thickness of the lining } \\
\text { divided by the conductivity of the material " } K "
\end{array}
\end{array}
$$

Typical values of " $K$ ", thermal conductivity in Btu/hr, per square foot, per degree "F" temperature difference, for one inch thickness are listed in Tables $3-I X$ and $3-X$ for fire clay and brick refractories.

" $K$ " values for ceramic fiber linings are shown in Figure 3-15.

The heat required to get refractories up to furnace operating temperature (heat storage effect) is listed in Table 3-XI.

To obtain " $K$ " factors from Tabies 3-IX, 3-X, and Figure 3-15, it is necessary to calculate the mean temperature. This is accomplished by adding $t_{1}$ and $t_{2}$ and dividing by 2. Thus mean temperature for this set of conditions is:

$$
\frac{1650^{\circ} \mathrm{F}-160^{\circ} \mathrm{F}}{2}=905^{\circ} \mathrm{F}
$$

Example: Determine heat loss through furnace walls lined with:
(a) Conventional brick refractory lining
(b) Laminated ceramic lining
(c) Full ceramic fiber lining

(a) Conventional refractory lining is composed of the following materials:

- 9" fire brick with a density of $147 \mathrm{lbs} / \mathrm{cu}$. ft.

- 4-1/2" insulated brick with a density of 31 1ba/cu. ft. 


\section{Therefore:}

$$
\text { Heat 1080 }=\frac{1650-160}{91+4.24}=289 \mathrm{Btu} / \mathrm{hr} / \mathrm{F}^{2}
$$

To find resietance " $R$ " for ingulated brick, enter Table 3-X at $905^{\circ}$ F (mean temperature) and read down to the $31 \mathrm{lb}$. density column, the resultant " $K$ " factor is approximately 1.06,

Therefore $R=\frac{4-1 / 2}{1.06}=4.24$

Total heat lose through furnace walls:

$=289 \mathrm{Btu} / \mathrm{hr} / \mathrm{ft}^{2} \times 570 \mathrm{sq}$. ft. $=164,730 \mathrm{Btu} / \mathrm{Hr}$.

(b) Laminated refractory lining is composed of:

- 9n fire brick with a density of $147 \mathrm{lb} / \mathrm{cu}$. ft.

- 4-1/2" insulated brick, density of $31 \mathrm{lbs} / \mathrm{cu}$. ft.

- 1" coramic fiber lining, density of $8 \mathrm{lb} / \mathrm{cu}$. $\mathrm{ft}$.

\section{Therefore:}

Heat LOsB $=\frac{1650-160}{.91+4.24+1.43}=226 \mathrm{Btu} / \mathrm{hr} / \mathrm{F}^{2}$

Total heat loss through furnace walls:

$=226 \mathrm{Btu} / \mathrm{Hr} / \mathrm{F}^{2} \times 570 \mathrm{sq} . \mathrm{ft} .=128,820 \mathrm{Btu} / \mathrm{hr}$.

(c) Full ceramic fiber lining composed of the following:

- 12" ceramic fiber at $8 \mathrm{lbs}$. density/cu. ft.

Therefore:

Heat LOBg $=\frac{1650-160}{17.14}=87 \mathrm{Btu} / \mathrm{hr} / \mathrm{F}^{2}$ 
To find resistance " $R$ " for ceramic fiber, enter Figure 3-15 at $905^{\circ}$ F., extend up to the $8 \mathrm{lb}$. density column and read 0.7 at the left hand side of the graph, therefore:

$$
R=\frac{12}{0.7}=17.14
$$

Total heat loss through furnace walls:

$=87 \mathrm{Btu} / \mathrm{hr} / \mathrm{Ft}^{2}$ x $570 \mathrm{Sq} . \mathrm{Ft} .=49,590 \mathrm{Btu} / \mathrm{hr}$.

TABLE 3-XII. SUMMARY - HEAT LOSS FOR VARIOUS LININGS

\begin{tabular}{|l|c|c|}
\hline ITEM & Btu/hr & $\begin{array}{c}\text { \% Savings over } \\
\text { Basic Refract. }\end{array}$ \\
\hline Conventional Refractory & 164,730 & $-0-$ \\
Laminated Refractory & 128,820 & $22 \%$ \\
Ceramic Fiber & 49,590 & $70 \%$ \\
\hline
\end{tabular}

Equivalent total gas usage reduction, utilizing ceramic fiber lining, is $164,730-44,590=115,140 \mathrm{Btu} / \mathrm{hr}$ or 1.15 Therms per hour.

Based on a continuous heat treat operation (with furnace in equilibrium) of 16 per day, 5 days per week-50 weeks per year, the total yearly gas savings would be as follows:

$$
\frac{115,140 \mathrm{Btu} / \mathrm{Hr} \times 16 \times 5 \times 50}{100,000 \mathrm{Btu} / \text { Therm }} \times \$ 0.3=\$ 1,382.00 \text { per year }
$$

Batch type heat treat operation is very costly in terms of gas usage due to the input energy required to heat the refractory mass up to furnace operating temperature, the following table illustrates the amount of energy required to heat the refractory to $1,600^{\circ} \mathrm{F}$. versus that required for ceramic fiber:

TABLE 3-XIII. EFFECT OF USE OF CERAMIC FIBER INSULATION

\begin{tabular}{|c|c|c|}
\hline ITEM & $\begin{array}{c}\text { 1/Heat Capacjut: } \\
\text { Stored - Btu }\end{array}$ & $\begin{array}{c}\text { \% Savings over } \\
\text { Bas ic Refractory }\end{array}$ \\
\hline Conv. Refractory (13-1/2") & $17,898,000$ & \\
Ceramic fiber (12") & $1,333,800$ & $92.5 \%$ \\
\hline
\end{tabular}

* Based on $570 \mathrm{sq}$. ft. Inside furnace area and heat storage figures from Table IV. 
Operating batch furnaces on a rapld change-over schedule will realize substantial fuel savings, also consideration must be given to the product to be processed. The scheduling effort to load to design capacity wi11 be more than offset by the fuel savings obtained by reduced heating of the lining.

Quantitative figures for overall savings, as a percentage of gas input to furnace, for upgrading conventlonal lining cannot be stated due to the many variables encountered in actual heat treat practices as applied to individual foundry operations. Savings shown in the example calculations, for lining replacements is attributed to radiation loss savings only.

Improving Combustion Efficiency

A Heat Treat Furnace has the following characteristics (from input data sheet);

- Furnace size: $20^{\prime} \times 10^{\prime} \times 8 \mathrm{ft} \cdot \mathrm{high}$.

- Furnace capacity: 20,000 1bs.

- Operating temperature: $1,650^{\circ} \mathrm{F}$.

- $5 \% \mathrm{CO}_{2}$ in flue gas.

- Flue gas temperature: $1,650^{\circ} \mathrm{F}$.

- Natural gas flow rate: $116 \mathrm{Terms} / \mathrm{Hr}$. or $11,600 \mathrm{cu}$. ft.

- Furnace physical condition: $1 / 4^{\prime \prime}$ crack visible all around door.

Calculate present combustion and furnace efficlency and probable furnace efficlencies if the furnace was upgraded as follows:

- Install nozzle mix burners with flue/air ratio controls.

- Install furnace pressure controls.

- Install hot gas recuperator for preheating combustion alr.

- Repalr furnace door and seal cracks.

Example No. 1: Calculate present excess air and avallable heat.

Excess air through burner system with $5 \% \mathrm{CO}_{2}$ in flue gas (from Figure $3-9)$ is $130 \%$.

Therefore, avallable heat to do work, (from F1gure 3-10) with 130\% excess air and $1,650^{\circ} \mathrm{F}$. flue gas temperature, is $20 \%$ of $11,600 \mathrm{cu}$. $\mathrm{ft} . / \mathrm{Hr}$. of natural gas which is:

$11,600 \mathrm{cu} \cdot \mathrm{ft} / \mathrm{Hr} \times 0.20=2.320 \mathrm{cu}$. ft/Hr or $2,320,000 \mathrm{Btu} / \mathrm{Hr}$

Example No. 2: Calculate secondary excess air infiltration due to door leakage.

From Figure 3-16 A with an average furnace temperature of $1,650^{\circ} \mathrm{F}$., the furnace negative pressure due to chimney effect is 0.011 " WC per foot of furnace helght. 
Therefore, total negative pressure 18 $0.011 \times 8=0.088$ "WC.

From Figure 3-16B with a total furnace negative preasure of 0.088 , the alr infiltration 18 approximately 280 cubio feet per hour per square inch of crack opening.

Therefore, total crack opening 18 , based on 28 linear feet of door circumference, 336 inches $\times 1 / 4^{\prime \prime}=84 \mathrm{gq}$. Inches.

From Figure 3-16A with an average furnace temperature of $1,650^{\circ} \mathrm{F}$, approximately 35 Btu is necesaary to heat each cuble foot of infiltrated alr, therefore, total heat required is:

35 Btu $x 84$ sq. Inches $\times 280 \mathrm{cu}$. $\mathrm{ft} / \mathrm{Hr} / \mathrm{sw}$. Inch $=823,200 \mathrm{Btu} / \mathrm{Hr}$. Present Combustion Efflolency

$\begin{array}{ll}\text { From Example 1. Avallable heat } & =2,320,000 \mathrm{Btu} / \mathrm{hr} . \\ \text { From Example 2. Heat Lost (Infiltration) } & = \\ \text { Net Heat Avallable } & =1,496,800 \mathrm{Btu} / \mathrm{hr} . \\ \text { Efflelency }=\frac{1,496,800}{11,600,000} \times 100=12.9 \%\end{array}$

Example No. 3: Calculate probable combuation efficiency after installing new burner syatem and sealing furnace cracks. $\mathrm{CO}_{2}$ content corrected to 118 and positive pressuxe maintained in furnace.

Available heat to do work (from Figure 3-10) with 108 .

Excess atr is $538 \times 11,600,000 \mathrm{Btu} / \mathrm{hr}=6,148,000 \mathrm{Btu} / \mathrm{hr}$

Net increase in heat content available is:

$$
\begin{aligned}
& 6,148,000 \mathrm{Btu} / \mathrm{hr}-1,496,800 \mathrm{Btu} / \mathrm{hr}=4,651,200 \mathrm{Btu} / \mathrm{hr} \\
& \text { or } 75.658 \text { increase }
\end{aligned}
$$

Based on 5 days per week, 50 weeks per year heat treat operation with heat-up time averaging 6 hours, the yearly energy savings would amount to:

$$
\begin{aligned}
& \frac{4,651,200 \mathrm{Btu} / \mathrm{hr} \times 5 \times 50 \times 6}{100,000 \mathrm{Btu} / \text { Therm }}=69,000 \text { Therms per year. } \\
& \text { At } \$ 0.30 \text { per therms, dollar savings would be } \$ 20,700 / \text { year }
\end{aligned}
$$


From the preceding examples approximately $5,452,000 \mathrm{Btu} / \mathrm{hr}$ $(11,600,000-6,148,000)$ is lost through the exhaust stack and radiation losses through the furnace walls. By preheating the combustion alr with the use of a hot gas recuperation, the following additional energy savings can be realized.

Example No. 4: W1th flue gas temperature of $1650^{\circ} \mathrm{F}$, calculate the energy savings if combustion alr is preheated to $1200^{\circ} \mathrm{F}$.

From Figure No. 3-12 the resultant fuel savings will amount to approximate1 y $28 \%$.

Therefore, additional heat saved per hour

$=0.28 \times 11,600,000 \mathrm{Btu} / \mathrm{hr}=3,248,000 \mathrm{Btu} / \mathrm{hr}$

Annual energy savings, using same operating time as stated in example 3 , is:

$$
\frac{3,248,000 \mathrm{Btu} / \mathrm{hr} \times 1,500 \mathrm{Hrs} .}{100,000 \mathrm{Btu} / \text { Therm }}=48,000 \mathrm{Therm} / \mathrm{yr}
$$

At $\$ 0.30$ per therm, dollar savings would amount to $\$ 14,400$

Overall Furnace Efficiency

The following table sumarizes the possible cost and energy savings by upgrading existing furnace.

TABLE 3-XIV. SUMMARY OF COST: AND ENERGY SAVINGS

\begin{tabular}{|l|c|c|c|c|}
\hline \multirow{2}{*}{ Item } & \multirow{2}{*}{$\begin{array}{l}\text { Btu/hr } \\
\text { Saved }\end{array}$} & $\begin{array}{l}\text { ENERGY } \\
\text { SAVINGS } \\
\text { PERCENT }\end{array}$ & $\begin{array}{l}\text { Annual Gas Savings } \\
\text { (Therms) }\end{array}$ & Cost \\
\hline Furnace Radiation Losses & 115,140 & $70 \%$ & 4,600 & $\$ 1,382$ \\
Improve Comb. Efficiency & $4,651,000$ & $53 \%$ & 69,000 & $\$ 20,700$ \\
Pre-heat Combustion Air & $3,248,000$ & $28 \%$ & 48,000 & $\$ 14,400$ \\
Total & $8,014,140$ & & 121,600 & $\$ 36,482$ \\
\hline
\end{tabular}

Overal1 Energy savings $=\frac{8,014,140}{11,600,000} \times 100=69 \%$

Note: The foundry industry, in general, is experfencing between 50 to $60 \%$ actual Energy Savings by upgrading their present heat treat furnaces. Energy calculations in Section 3 of this study are based on $56 \%$ savings. 
It must be restated that this analysis has been oversimplified to 11.ustrate the need for improving existing thermal efficlency. The examples used can be a valuable tool in estimating potential savings. A full heat balance and thermal analysis should be made by an expert in this fleld before a mafor convergion is made. The energy savings are there if product requirements can be adfusted toward that goal.

Economica1 Evaluation

(a) Replace exlsting burner system with a combination nozzle mix Burner system - recuperator package with completely pre-wired control system. (Equipment cost) $\ldots \ldots \ldots \$ 90,000$

(b) Replace conventional refractory lining with 12" thick ceramic fiber insulation - material cost .......\$15,000

(c) Labor to Install 1 tem No. $1 * \ldots \ldots \ldots \ldots \ldots \ldots \ldots \ldots \$ 40,000$

(d) Engtneerting costs...................... $\$ 10,000$

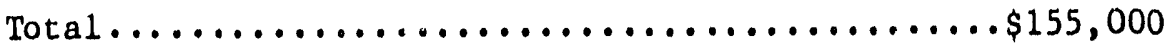

Pay Back Perlod $=\frac{\text { Capital Investment }}{\text { Energy Savings Cost }}=\ldots$ yrs.

Therefore: Pay Back $=\frac{\$ 155,000}{36,482}=4.25$ years

The above pay back period does not take into account future cost of natural gas which could increase as high as $15 \%$ per year, or government tax credits for installation of energy saving devices.

*Installation labor does not include the relining of the furnace. It is assumed that this labor would be performed by foundry maintenance personnel and expensed. 


\section{General}

Ladle Heating is a very necessary requirement in any foundry operation. It $1 \mathrm{~s}$ a large user of natural gas and probably represents the greatest abuse of gas energy in foundries today. This Section will examine the requirements for upgrading or replacing existing equipment for ladle drying and heating, covering the following:

- Ladle covers

- Burner efficiencies

- Improved insulation

Formulas, calculations, and graphs have been simplified within the scope of the project to reflect constant conditions during the process.

To investigate any process in depth it is essential to establish parameters, calculate the data and plot results on a continuous basis to establish the limits of the operation and equipment and identify any trends.

FIGURE 3-18

OPERATIONAL DATA FACT SHEET

LADLE PREHEAT DATA

LADLE CAP TONS 1.0

HEAT CYCLES/DAY 3

LADLE AREA INSIDE 12 SQ FT. LINING THICKNESS 2.5 ins. COVERED NO TYPE OF LINING Firebrick

INSIDE TEMP $1560{ }^{\circ} F$ OUTER SHELL TEMP $300^{\circ} \mathrm{F}$ AMBIENT TEIMP $N / A$ ${ }^{O} F$ GAS USAGE/HR $550 \mathrm{CU} F \mathrm{FT}, \mathrm{CO}, \mathrm{READING}$ $N / A$ COMBUSTION AIR N/A CFI PRESSURE

${ }_{-\cdots}^{-}{ }^{{ }}{ }_{F}$

PREHEAT CYCLE TIME 1.0 HRS FLUE TEMP

REFRACTORY $K$ VALUE 6 RS VALUE 0.33

BLOWER HP $N / A$ RECUPERATOR EFFCY

FUEL COST/THERM $\$ 0.3$ ANNUAL USE $N / A$ BTU $\times 10^{6}$

NUMBER OF UNITS IN USE 1 
Figure 3-19 shows typical relationship of time versus temperature to fuel input for uncovered and covered ladles both with tight fitting and ralsed covers.

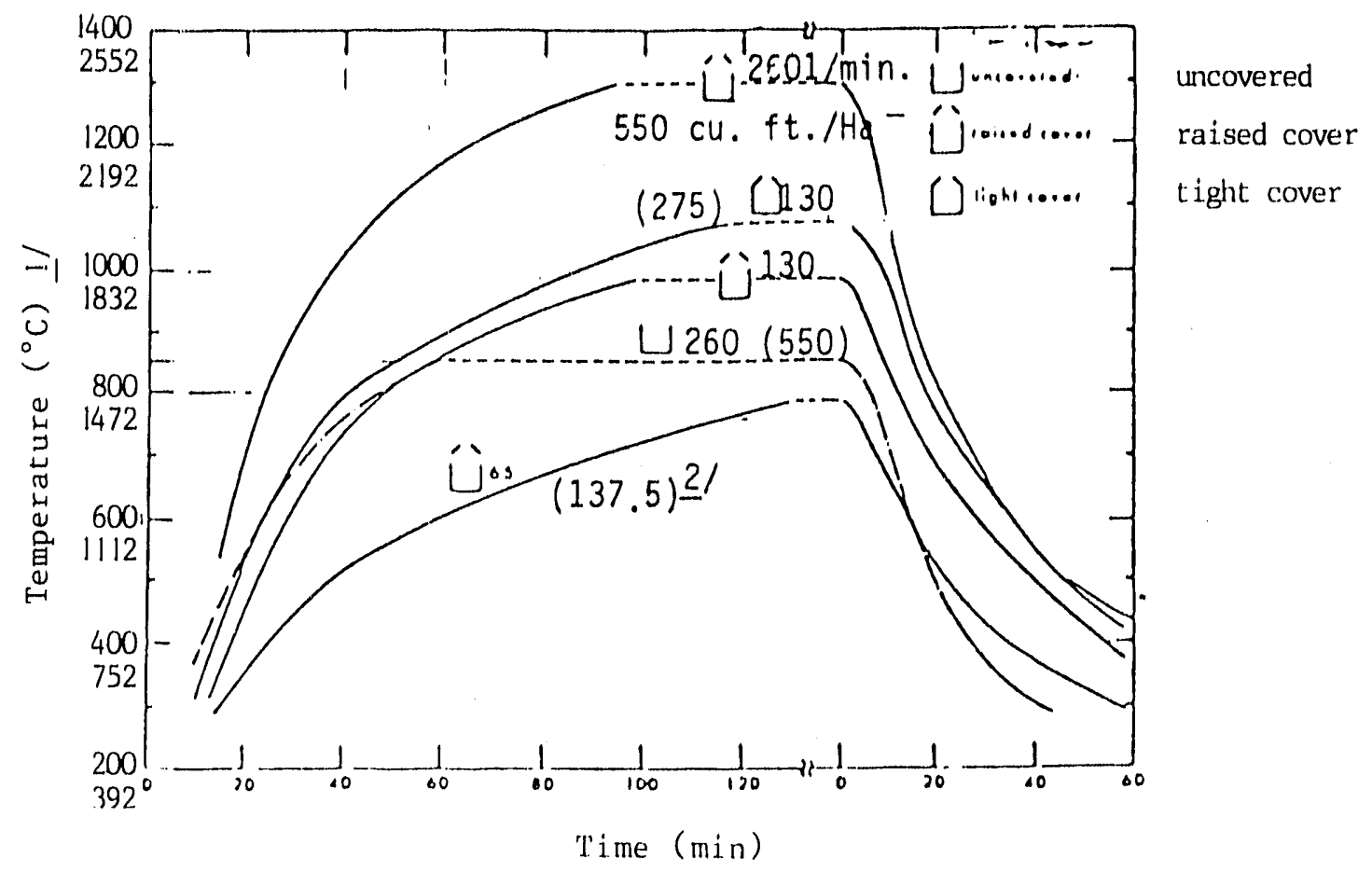

FIGURE NO. 3-19. EFFECT OF LADLE COVERS

1/ Temperatures both in ${ }^{\circ} \mathrm{C}$ and $\mathrm{O}_{\mathrm{F}}$ at the inside bottom of the Ladle.

2/ Figures shown as gas flow rates in liters per min. and cubic feet per hour.

Example of use: Curve is developed for speciflc ladle size with measured gas flow rates.

Read elapse time from intersection of curve with temperature.

For covered ladle at $275 \mathrm{cu}$. $\mathrm{ft} /$ hour gas flow, the time to attain required temperature $850^{\circ} \mathrm{C}$, is approximately 50 minutes. 
FIGURE $3-20$

\section{HEATING CHARACTERISTICS}

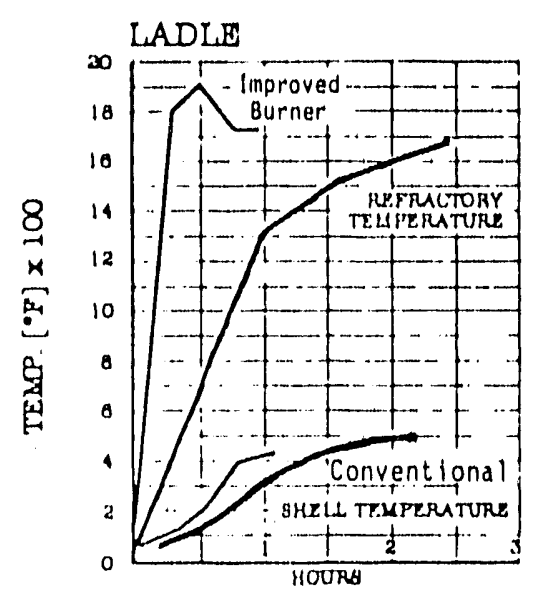

FIGURE $3-21$

FUEL CONSUMPTION

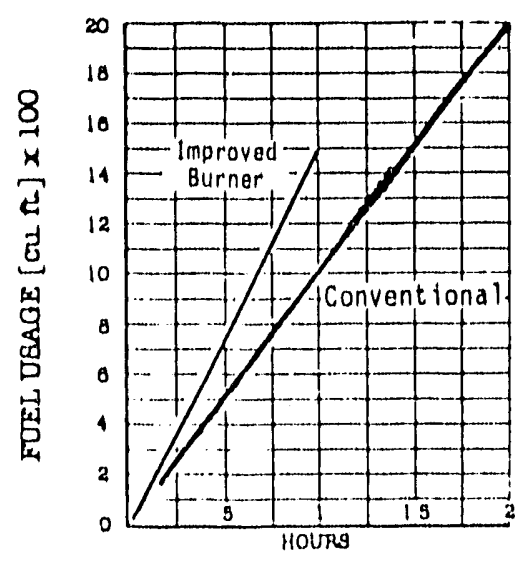

Reference: Hotwork Mfg. Inc.

Example of use:

Figure 3-20: Read elapsed time hours at intersection of temperature with approved burner graph line; then,

Figure 3-21: Obtain fuel usage for improved burner by reading up from elapsed hours to intersection with graph 1ine and across to fuel usage.

For example: At temperature requirement of $1300^{\circ} \mathrm{F}$, read approximately 0.25 hours (for improved burner) from Figure 3-20.

Transfer hours (0.25) onto Figure 3-21 and read approximately 400 cu. ft. fuel used by improved burner. 
TABLE 3-XI. THERMAL PROPERTIES OF CONCRETES

- Fyoleal thermal Propertles of Rervactory and insulating concrates IHIa

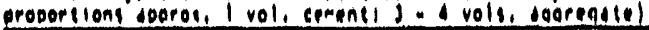

\begin{tabular}{|c|c|c|c|c|}
\hline Agorrente. & $\begin{array}{l}\text { lired } \\
\text { densiligy, } \\
\text { lo. pirs } \\
\text { cub. } 16 .\end{array}$ & 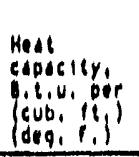 & 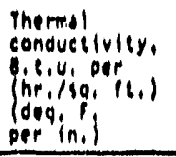 & 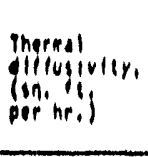 \\
\hline Vemievillo & $5 s$ & 9 & 1.2 & 0.011 \\
\hline Dlatemile & $s 5$ & 10 & 1.9 & 0.010 \\
\hline $\begin{array}{l}\text { Crussed } N_{1} \text { T, insu- } \\
\text { lating ories }\end{array}$ & 85 & 21 & 3.2 & 0.013 \\
\hline Capanded clor & 90 & 22 & 3,5 & 0.013 \\
\hline Crushed flrebrich & ils & 29 & 6 & 0.011 \\
\hline Iblochile & 120 & 31 & $B$ & .0 .021 \\
\hline s1111-anite & 135 & 33 & 10 & 0.025 \\
\hline carborundum & 145 & 40 & 50 & 0.103 \\
\hline calcined bavalle & 160 & 45 & 12 & 0.022 \\
\hline Magnesilte & 160 & 45 & 20 & 0.031 \\
\hline Chroreemagneslle & 165 & 31 & 8 & 0.013 \\
\hline fused magnested & 110 & 50 & 24. & 0.04 \\
\hline Puied alumina & 173 & 32 & 16 & 0.026 \\
\hline Subole dimina & 95 & 22 & 6 & 0.023 \\
\hline
\end{tabular}

TABLE 3-XVI. THERMAL CONDUC'TIVITY OF CONCRETES

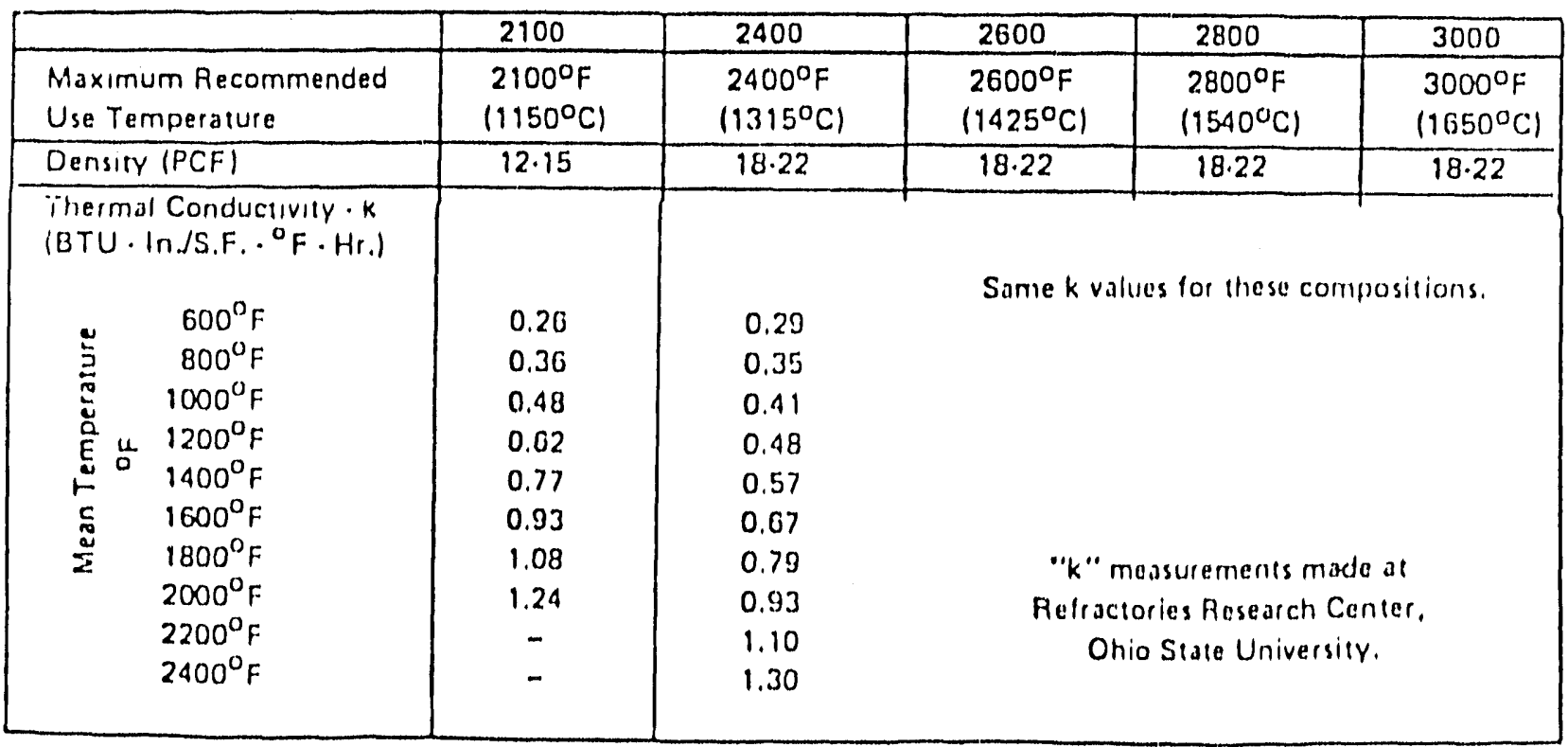

* Ref. Industrial Insulations Inc. 


\section{SAMPLE CALCULATIONS}

\section{Ladle Covers:}

Heat loss during pre-heat of ladle relates to time in attalning required temperature measured at the inolde bottom of the ladle.

Typical burner olzes for average ladle capactites of 1 ton (tron) 16 $1.0 \times 10^{6} \mathrm{Btu} / \mathrm{hr}$. Therefore energy savings for any capactity ladie car be prorated based on pre-heat time for any size burner.

\section{Example:} cu.ft./hr.

Burner size $1^{\prime \prime}\left(1.0 \times 10^{6} \mathrm{Btu} / \mathrm{hr}\right)$ shows a gas flow rate of 275

The elapsed time to attain $850^{\circ} \mathrm{C}\left(1560^{\circ}\right.$ F) with the tight-cover ladle, is approximately 50 minutes, reference Figure 3- 19.

Thus gas usage $=\frac{50}{60} \times 275,000=0.230 \times 10^{6} \mathrm{Btu}$.

The elapsed time to attain $850^{\circ} \mathrm{C}\left(1560^{\circ} \mathrm{F}\right)$ with a ralsed cover ladle utilizing gas flow rate of $275 \mathrm{cu} . \mathrm{ft} . / \mathrm{hr}$, is approximately 50 minutes, reference Figure 3-19.

Thus gas usage $=\frac{60}{60} \times 275,000=0.275 \times 10^{6} \mathrm{Btu}$

The elapsed time to attain $850^{\circ} \mathrm{C}\left(1560^{\circ} \mathrm{ir}\right)$ with an open ladle utilizing gas flow rate of $550 \mathrm{cu} . \mathrm{ft} . / \mathrm{hr}$ is approximately 60 ininutes, reference Flgure 3-20.

Thus gas usage $=\frac{60}{60} \times 55,000=0.55 \times 10^{6} \mathrm{Btu}$

Relative savings for the alternate arrangements 1s:

\begin{tabular}{|l|c|c|}
\hline Item & Btu's & Change in energy \\
\hline Uncovered ladle & 550,000 & $-0-$ \\
Raised cover ladle & 275,000 & $-50.0 \%$ \\
Tight cover ladle & 230,000 & $-58.0 \%$ \\
\hline
\end{tabular}


In quantitative termo the covered ladle (tight cover) results in gas usage reduction of:

$$
550,000 \times 0.58-320,000 \mathrm{Btu} / \mathrm{hr}
$$

At $\$ 0.30$ per therm, cost reduction $=\$ 0.96 / \mathrm{hr}$

Based on $20 \%$ ut11lzation, 8 hours/day, 240 days per year, the annua 1 cost reductions:

$$
0.96 \times 8 \times 240 \times 0.2=\$ 370
$$

It should be noted that the example 18 worked for one ladle only whereas generally more than one ladle is in use dally. Also slze of ladle and therefore burner stze will have impact on total posalble savings.

\section{COMBUST ION SYSTEMS}

High efflitency burners reduce drying and preheating time which translates into increased ladle utilization and energy reduction.

Comparison between a conventional burner (high intensity) and a high efficlency burner is shown in Figure 3-20 and Figure 3-2 1 .

Example: Time required to ralse ladle refractory to $1300^{\circ} \mathrm{F}$ is 1 hour, using conventional burner.

Ind lcated time for Improved burner with high efficlency characteriatics, is shown on Figure 3-20 to be approxl nately 0.25 hours. With fuel usage of $1,000 \mathrm{cu}$. ft. and $400 \mathrm{cu}$. ft. respectively as Indicated on Figure $3-22$.

Thus efficlency Improvement is calculated from

$$
\begin{aligned}
& \frac{\text { Fuel usage reduction } \times 100}{\text { Orlginal fuel usage }}=\text { percent } \\
& \text { Therefore: } \frac{(1,000-400) \times 100}{1,000}=60.0 \%
\end{aligned}
$$

Equivalent energy reduction for ladle preheating in previous example using $230,000 \mathrm{Btu} / \mathrm{hr}$, the gas usage reduction 1s:

$$
230,000 \times 0.60=138,000 \mathrm{Btu} / \mathrm{hr} .
$$

At $\$ 0.30$ per therm, the cost reduction

$$
\frac{138,000 \mathrm{Btu} / \mathrm{hr} \times 0.3}{100,000 \mathrm{Btu} / \mathrm{Therm}}=\$ 0.414 / \mathrm{hr}
$$


Based on $20 \%$ ut111zation, 8 hours/day, 240 days per year, the annual cost reduction 1s:

$$
\$ 0.414 \times 8 \times 240 \times 0.2=\$ 160
$$

INSULATION

Ladle insulation and covers increase heating efficlency which leads to quicker heating and thus less time for losing energy by conduction and radiation through the ladle walls. Improved wall Insulation saves energy in two ways, first by reduction in pre-heat gas requirements and second by minimizing the metal temperature $108 s$ during the pour, thus lowering the Inttial superheat required by the melter and extending the usable pourting pertod of the ladle with the possibility of reducing scrap castings by pouring less cold metal.

Example of energy savings by Instaling $1 / 2$ Inch Insulation between the 2 Inch refractory and the shell. The heat lost during ladie preheating is to be calculated and compared to lining without insulation.

Area of 1 ining $30^{\prime \prime} \mathrm{d}$ la. $x 30^{\prime \prime}$ deep $=12 \mathrm{sq}$. ft.

Heat loss through conventional Infag matertal is calculated from

$$
\begin{aligned}
& Q=\frac{t_{1}-t_{2}}{R_{1}+R_{2}}=B t u / S q \cdot F t / h r \\
& \text { Where } R=\frac{\text { Th1ckness of Lining }}{K^{\prime \prime} \text { value }} \\
& t_{1}=\text { hot face temperature }\left(1300^{\circ} \mathrm{F}\right) \\
& t_{2}=\text { cold face temperature }\left(200^{\circ} \mathrm{F}\right) \\
& K=\text { thermal conductivity of 11ning meterial from F1gure } 4 \\
& \text { and F1gure } 5
\end{aligned}
$$

Thus Qa (no Insulation) $=\frac{(1300-200)}{R_{1}} 12$ sq.ft.

$$
R_{1} \text { (high alumina cement) }=\frac{2.5 \text { Inches }}{K}=\frac{2.5}{6}=0.42
$$$$
Q=\frac{1100 \times 12}{0.42}=31,400 \mathrm{Btu} / \mathrm{hr}
$$

$Q b($ with insulation $)=\frac{(1300-200)}{R_{1}+R_{2}} 12$ 
$R_{1}=\frac{2 \text { inches }}{6}=0.333$

$R_{2}$ (ceramic fiber) $=\frac{0.5}{\mathrm{~K}}=\frac{0.5}{0.29}=1.72$

Note: Ceramic fiber layer assumed to have a mean temperature below $600^{\circ} \mathrm{F}$.

$Q b=\frac{1100 \times 12}{0.333+1.72}=6,400 \mathrm{Btu} / \mathrm{hr}$

Reduction in heat loss $=31,400-6,400=25,000 \mathrm{Btu} / \mathrm{hr}$

Equivalent to $79.6 \%$ savings in energy .

From previous example, net reduction in energy usage is:

$31,400 \mathrm{Btu} / \mathrm{hr} \times 0.796=25,000 \mathrm{Btu} / \mathrm{hr}$

At $\$ 0.30$ per therm, cost reduction

$$
\frac{25,000 \times 0.3}{100,000 \mathrm{Btu} / \text { Therm }}=\$ 0.075 / \mathrm{hr}
$$

Based on $20 \%$ utilization, 8 hours per day, 240 days per year, annual energy cost savings is $=0.075 \times 8 \times 240 \times 0.2=\$ 28.80 /$ year .

SUMMARY (PROBABLE ENERGY SAVINGS)

The following table summarizes present and probable energy requirements for ladle heating as determined in sample calculations if all the improvements are carried out.

TABLE 3-XVII. PROBABLE SAVINGS

\begin{tabular}{|l|c|c|c|c|}
\hline \multicolumn{1}{|c|}{ ITEM } & $\begin{array}{c}\text { BTU/HR } \\
\text { SAVED }\end{array}$ & \%SAVINGS & GAS THERMS & \multicolumn{1}{c|}{ SAVINGS } \\
COST \$
\end{tabular}

Actual overall energy saving between $50 \%$ and $60 \%$ is considered to be practical for the majority of ladie heating operations. Additional savings can be realized if ladle heater utilization is reduced to $15 \%$ of the typical 8 hour shift period. 
Item

1. Provide Insulated cover (material cost)

$=\$ 500.00$

2. Replace burner with 'High Efficlency' unit with gas controls

$=4,000.00$

3. Add insulation to ladle lining

$1 / 2$ " $12 \mathrm{gq}$. ft. (material cost) = 50.00

4. Labor to install cover

SUBTOTAL

5. 108 Engineering cost

TOTAL
450.00

$\overline{5,000.00}$

500.00

$\$ 5,500.00$

Note - Installation of insulated lining is assumed to be carried out during normal reline schedule and labor cost is expensed. The above costs are "order of magnitude" only. 
C. COKE FUEL MELTING - CUPOLA

GENERAI

Methods of melting to be analyzed in this section are:

- Lined Cold Blast Cupola

- Lined Cupola With $500^{\circ}$ F Hot Blast

- Water Cooled Cupola With $1,000^{\circ} \mathrm{F}$ Hot Blast

- Divided Blast Cupola, Cold Blast

- Lined Cupola, Cold Blast with 2-48 Oxygen Enrichment

COKE USAGE

The conventional cupola is a vertical shaft type furnace with a refractory lining and equipped with a windbox and tuyeres for the admission of air. The sequential material charges, through the stack of the cupola, comprise alternate layers of metallics and coke with some fluxes added. The descending fuel replaces that burned from the original coke bed and maintains the height of this bed.

COKE BED CALCULATIONS

Example

Recommended coke bed height above the tuyeres is;

$10.5 \times \mathrm{sq}$. root of blast pressure (ounces) +6 *

Therefore if windbox pressure $=16$ ounces

Bed coke height $=(10.5 \times \sqrt{16})+6=48^{\prime \prime}$

Thus the volume of bed coke required per melt campaign is obtainable by reference to Table 3-XVIII. Consider above example and determine weight of coke required in initial bed as follows:

Read Table 3-XVIII, for volume at $16 \mathrm{onz}$. pressure $=38.5 \mathrm{cu}$. ft., therefore at $30 \mathrm{lbg} / \mathrm{cu}$. ft., weight of coke $=1155 \mathrm{lbg}$.

Additional coke may be required to be added to maintain bed height during initial melt period, to obtain full burning of the bed prior to the first charge of metal, and for starting the blast. Additional coke to fill the hearth up to tuyere level, must be made based on opecific cupola design. Total energy required to operate the cupola, including bed coke and electric power, is to be calculated as shown on the work sheet as follow日:

*6 is a suggested factor which may have to vary for a specific cupola. 
STANDARD CALCULATION FORMAT FOR CUPOLA ENERGY DATA

Standard 48" Lined, Cold-Blast Cupola. (Desired melt rate $9.0 \mathrm{TPH}$ )

Melt rate TPH. $9.0 \times 2000 \quad 18,000 \quad$ LBS $/$ HR.

Metal to Coke ratio 10:1, Coke charged/hr_ 1,800 1bs.

CFM air Reqd. 4,100 @ Blast Pressure 18 ONZ

Fan HP . . . . . . 50.0

Skip Loader . . . . 7.5

Dust Collector . . . 55.0

Misc. Power ...... 5.0

Equivalent BTU/HR $\frac{117.5 \times .746 \times 3412}{1.73}=172,878$

Coke Charged/HR . . . $1800 \mathrm{LBS} / \mathrm{HR}$

Bed Coke $\times 1 / 8$. . . . 225

Equivalent BTU/HR $2,025 \times 12,500=2,312,500$
TOTAL BTU/HR
AVERAGE BTU/TON OF METAL CHARGED $=25,713,410$

OPERATION OF SPECIAL CUPOLAS

Comparison of current cupola operation with alternate systems, hot blast type, divided blast or oxygen enilched blast, can be made by reference to the model energy chart graphs at specific melt rate requirements.

It assumed that the cupola melt rate, in all cases, is based on conventional practice prior to improvements.

TABLE 3-XVIII. BED COKE REQUIREMENTS

\begin{tabular}{|c|c|c|c|c|}
\hline $\begin{array}{c}\text { NORMAL } \\
\text { WINOBOX } \\
\text { PRESSURE } \\
\text { (O2) }\end{array}$ & $\begin{array}{c}\text { BED COKE } \\
\text { ABOVE } \\
\text { TUYERES } \\
\text { (IIICHES) }\end{array}$ & $\begin{array}{c}\text { MELT } \\
\text { DIAMETER } \\
\text { (INCHES) }\end{array}$ & $\begin{array}{c}\text { ZONE } \\
\text { AREA } \\
\text { (SGINS; }\end{array}$ & $\begin{array}{c}\text { VOL.UME } \\
\text { COKE } \\
\text { (CU.FT.) }\end{array}$ \\
\hline 7 & $28-34$ & 18 & 254 & 5.0 \\
12 & $36-42$ & 23 & 415 & 10.0 \\
14 & $40-46$ & 32 & 804 & 21.4 \\
16 & $42-48$ & 42 & 1,385 & 38.5 \\
18 & $45-51$ & 48 & 1,809 & 53.4 \\
20 & $47-53$ & 72 & 4,071 & 124.9 \\
\hline
\end{tabular}

As sumption:

Density of Cupola Coke $=30 \mathrm{lbs} / \mathrm{cu} . \mathrm{ft}$. 
GRAPHS, TABLES, AND CHARTS

TABLE 3-XIX. CUPOLA OPERATING CHARACTERISTICS

\begin{tabular}{|c|c|c|c|c|}
\hline $\begin{array}{c}\text { IRON TO } \\
\text { COKE RAT10 }\end{array}$ & $\begin{array}{c}\text { COKE PER } \\
\text { TON OF MELT } \\
\text { LB }\end{array}$ & $\begin{array}{c}\text { MELTING RATE } \\
\text { TONS PER HOUR }\end{array}$ & $\begin{array}{c}\text { METAL } \\
\text { TEMPERATURE } \\
\text { OF }\end{array}$ & $\begin{array}{c}\text { APPROXIMATE } \\
\text { THERMAL } \\
\text { EFF., } \%\end{array}$ \\
\hline 12 to 1 & 167 & 16.0 & 2,656 & 46.7 \\
11 to 1 & 182 & 15.2 & 2,672 & 43.0 \\
10 to 1 & 200 & 14.2 & 2,686 & 39.5 \\
9 to 1 & 222 & 13.1 & 2,706 & 36.0 \\
8 to 1 & 250 & 12.0 & 2,730 & 32.0 \\
7 to 1 & 286 & 10.9 & 2,762 & 28.4 \\
6 to 1 & 333 & 9.8 & 2,798 & 27.0 \\
\hline
\end{tabular}

\section{LINED CUPOLA - IRON MELTING}

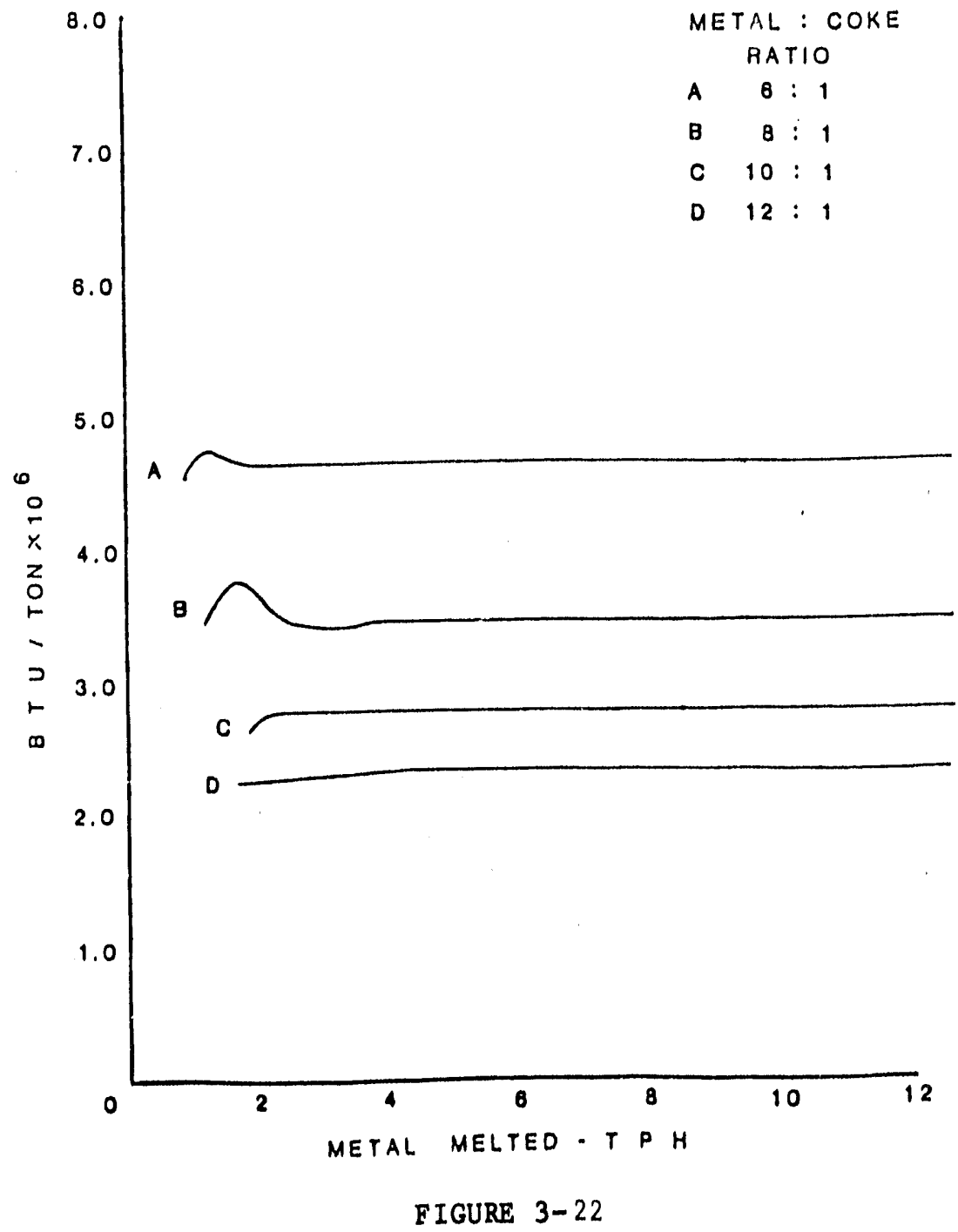

CUPOLA OPERATING CHARACTERISTICS - LINED CUPOLA - IRON MELTING 
MELTING GRAY IRON

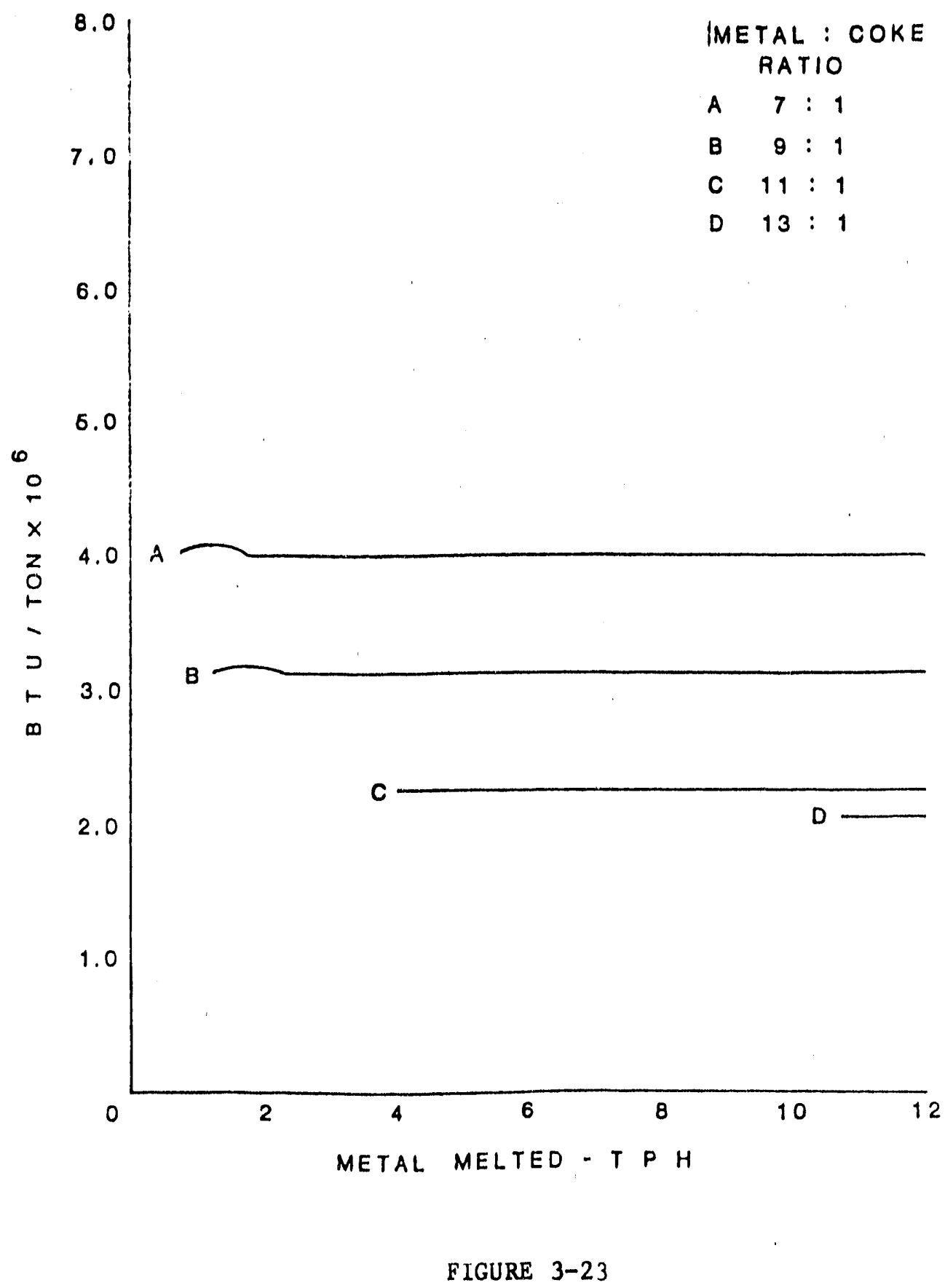

CUPOLA OPERATING CHARACTERISTICS - LINED CUPOLA, 500\% HOT BLAST 


\section{MELTING GRAY IRON}

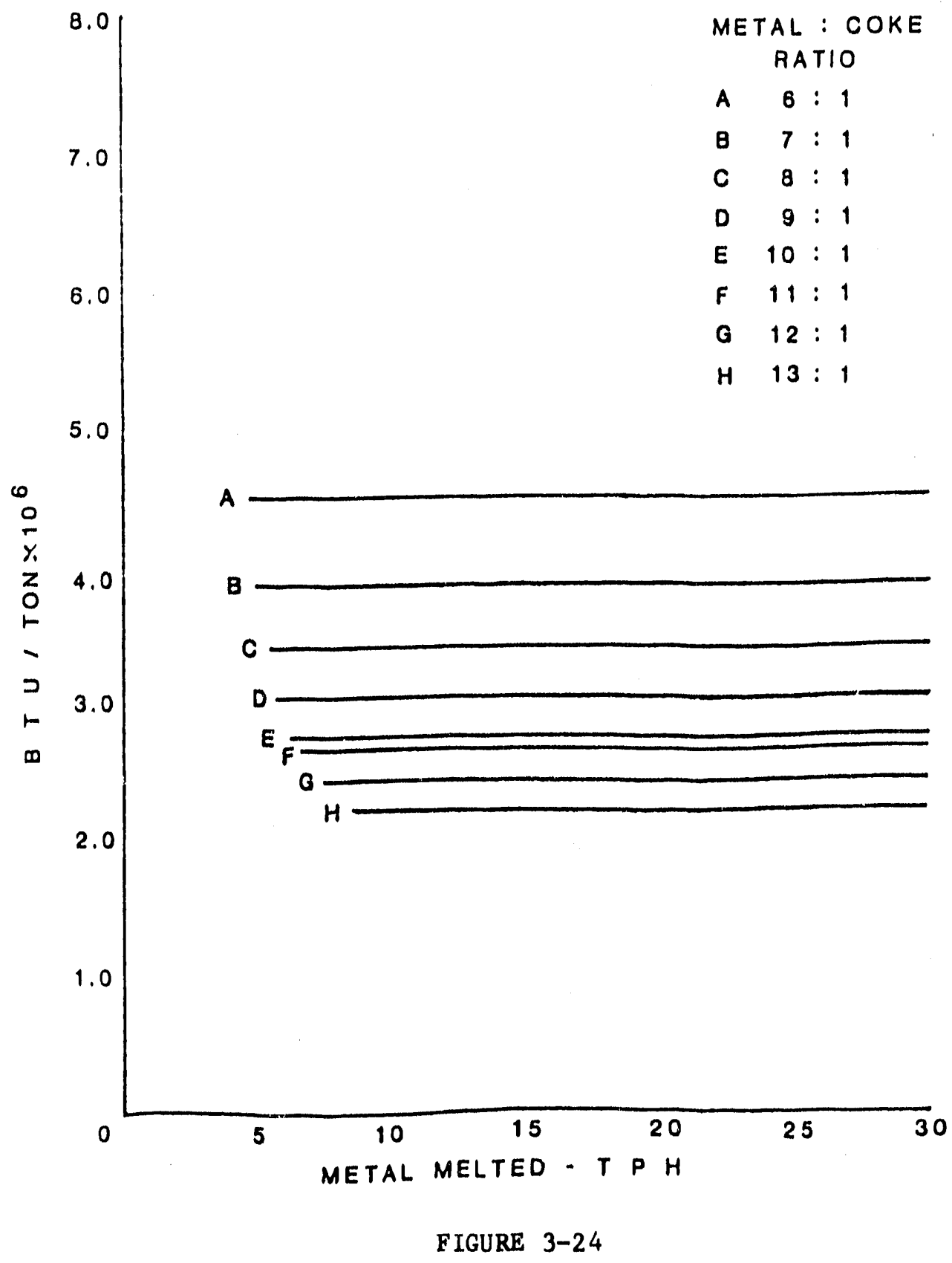

CUPOLA OPERATING CHARACTERISTICS - LININGLESS $1000^{\circ} \mathrm{F}$ HOT BLAST CUPOLA 
MELTING GRAY IRON

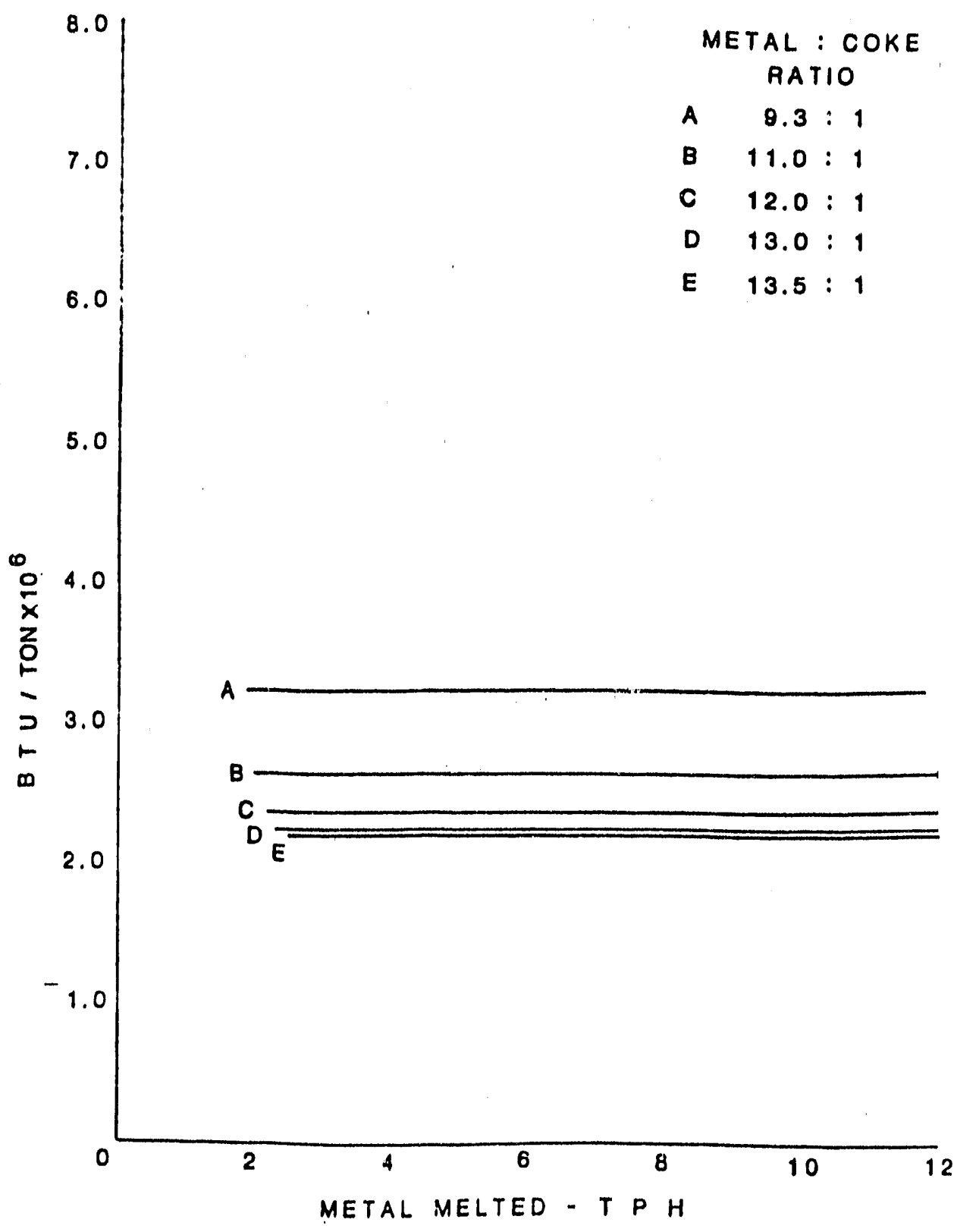

FIGURE 3-2 5

CUPOLA OPERATING CHARACTERISTICS - DIVIDED-BLAST CUPOLA 
MELTING GRAY IRON

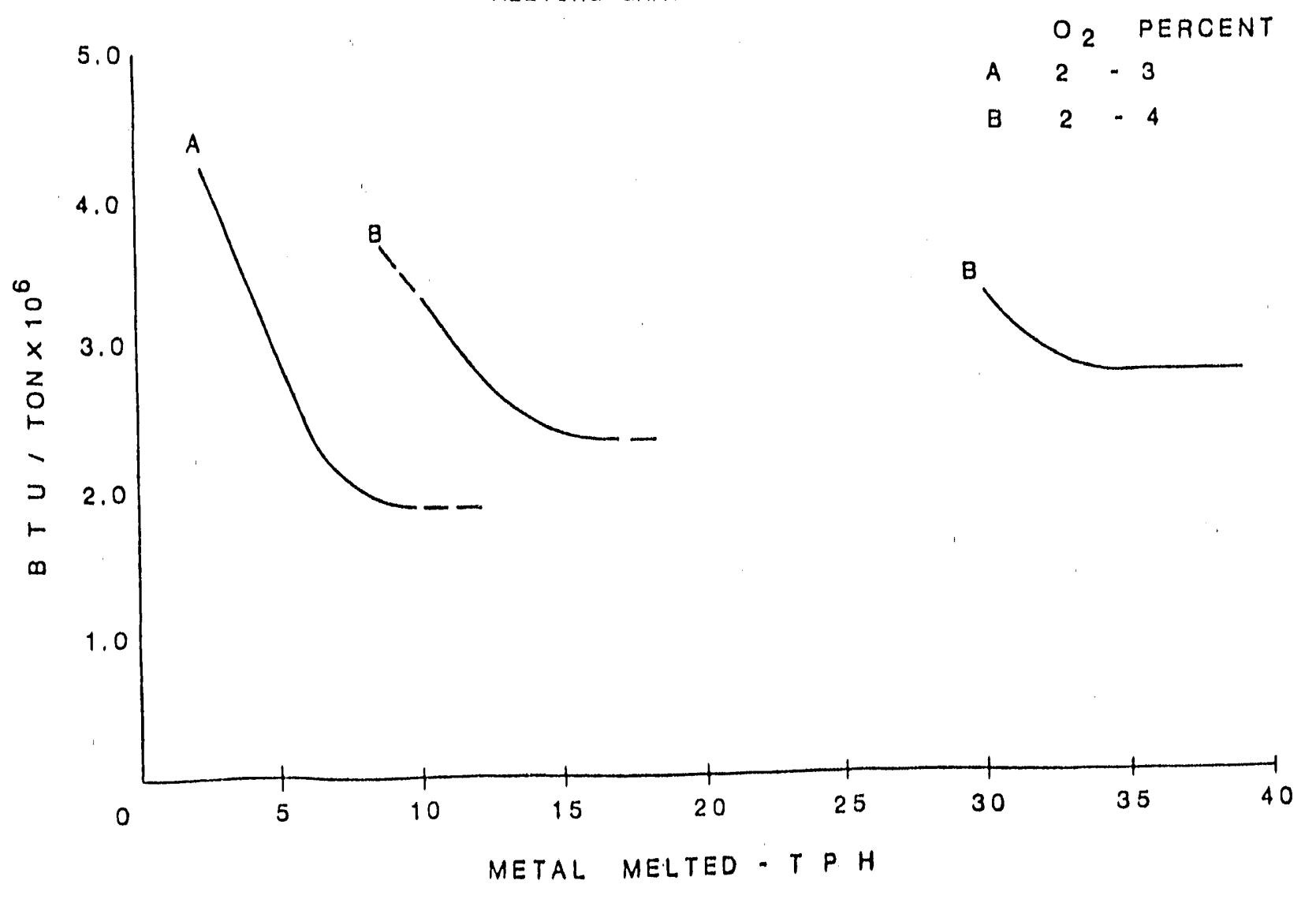

FIGURE 3-26

CUPOLA OPERA'TING CHARACTERISTICS

LINED COLD BLAST CUPOLA WITH OXYGEN ENRICHED BLAST 
FIGURE 3-27

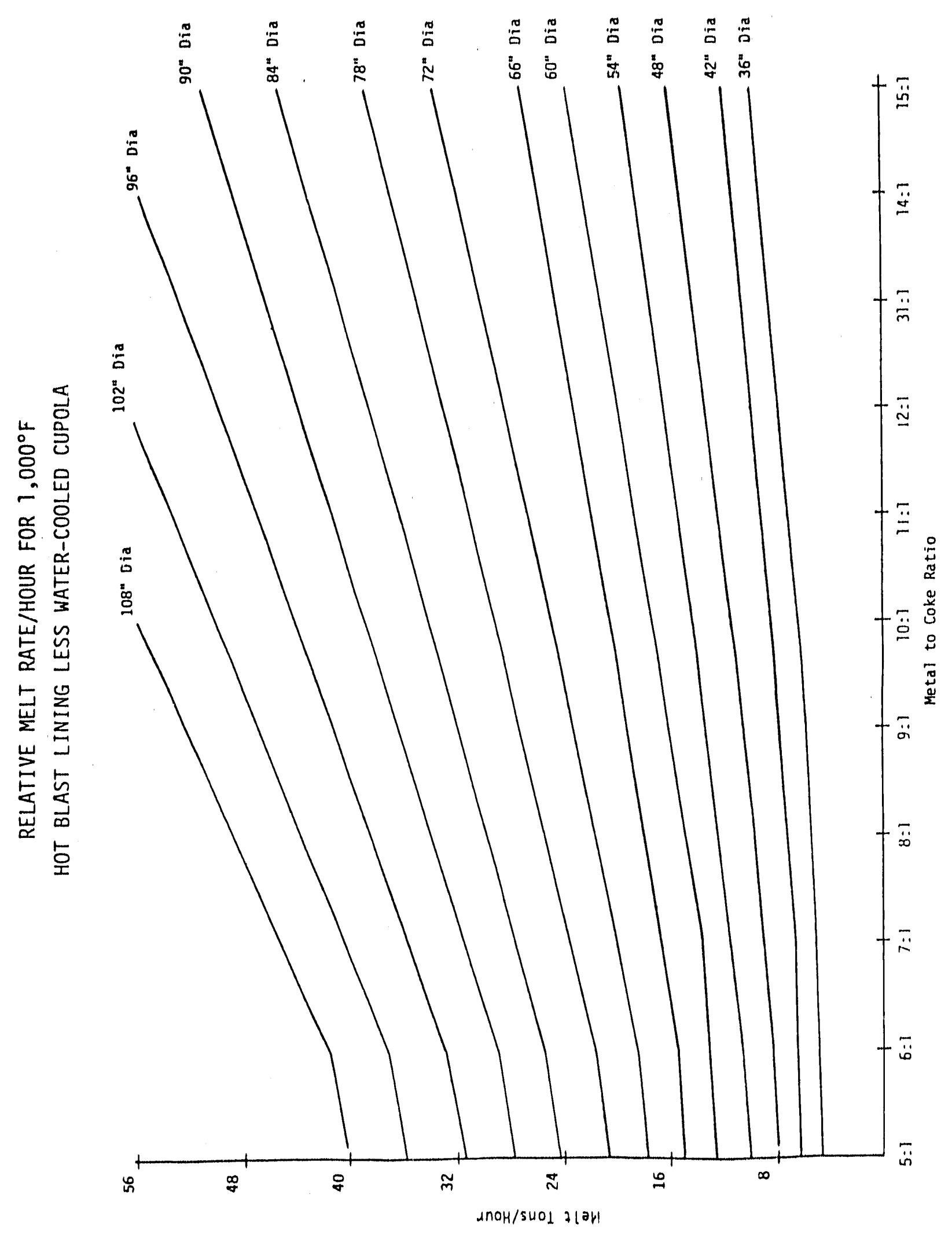


Figure $3-28$

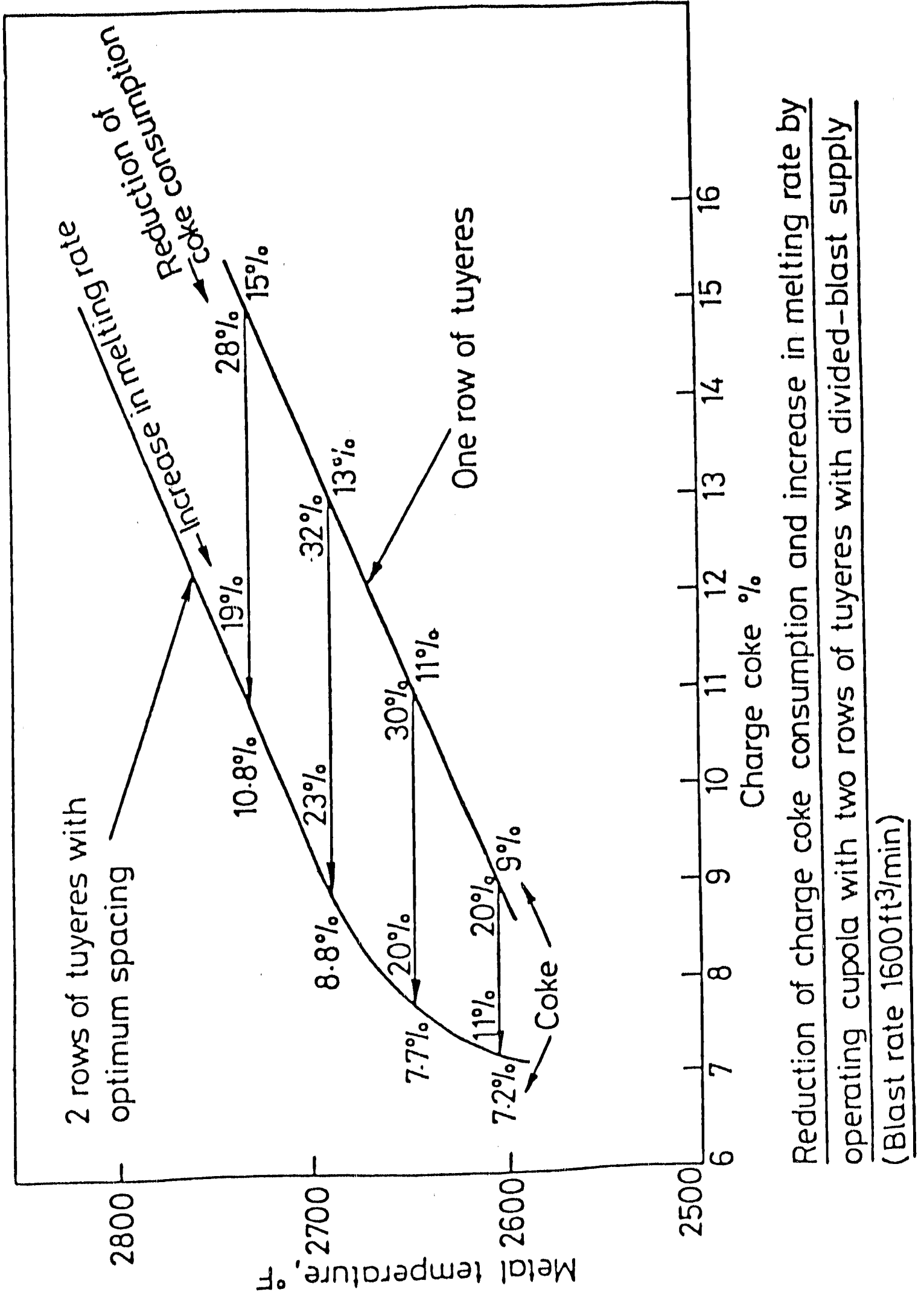


The range of dzes and operating reoommendatione for conventional oupolas has bean developed over a long perlod of time realting in falrly atandard data (wee Table 3-XIX). Ratlo of metal welght to ooke charged, exoluding the bed ooke, determines the melt rate and/or temperature of iron as it leaves the cupola with oonventional designed oupolas. Higher tapping temperatures involve o penalty in coke urage and melt rate.

\section{Bxample}

If metal ig to be tapped from a oupola at $2,762^{\circ} \mathrm{F}$, oaloulate the energy (ooke) penalty compared to tap temperature of $2,686^{\circ} \mathrm{F}$. From Table X-XIX, a oupola produoing 10.9 tong per hour with lron to ooke ratio of $7: 1$ for $2,762^{\circ}$ F tap temperature, results in approximate thermal efflolenoy of 28.48 at $2,686^{\circ} \mathrm{F}$. 1 the oupola would produce 14.2 tong/hour with iron to ouke ratio of $10: 1$ and approximate thermal offlolenoy of 39.58 .

Thus at $7: 1$ ratio, coke usage $=286 \mathrm{lbg} / \mathrm{ton}$ melted

$10: 1$ ratio coke usage $=2001 \mathrm{bs} /$ ton melted

Reduation $\quad=\overline{86} \mathrm{lbg} /$ ton melted

$\therefore$ Penalty for $76^{\circ} \mathrm{F}$ auper heat 1 s equivalent tor

$86 \times 12,500 \mathrm{BTU} / 1 \mathrm{~b}=1.075 \times 10^{6} \mathrm{BTU} /$ ton melted

At $\$ 0.09$ per lb for coke, the oogt difference

$86 \times 0.09=\$ 7.74$ per ton melt.ed melted

Annual energy reduotion based on 15,000 tons per year of metal

$$
\begin{aligned}
& =1.075 \times 10^{6} \times 15,000=16.125 \times 10^{6} \mathrm{BTU} \\
& \text { Energy reduction }=\frac{86}{286}=30.08
\end{aligned}
$$

Cost aavinge per year $=\$ 7.74 \times 15,000=\$ 116,100$

Thermal efficlency improvement $=39.5=28.4=11.18$

Note- In above example the coke bed helght in each case le the same and does not effect the melting energy difference.

Tap temperature reduction may be impractical without other operational improvements auch as ingulation of launders, pouring ladies, etc. Control of production scheduling is required to minimize holding periode or delays prior to pour off, also, redealgn of gating to enable lower casting pouring temperatures is another requirement. 
To obtain Inoreased melting or higher temperature and more offlolent coke uasge, refinoment to the vtandard oupola are avaliable.

Blast oondltioning, through utilization of roouperative hot blawt, oan be provided uaing the waste heat from the oupola exhaust.

\section{HOT BLAST SYSTHY}

Model energy uaage in BTU/ton of Lron malted oan be detarmined by referenoe to speolfic oharta and by profecting a point on the graph, at known matal to ooke ratio, from desired melt rate in tons per hour. (Figure $3-23-24$ )

Value determined from the graph can be oompared to proposed operation under new conditiona of operation, by calculation of actual energy uagge differenoe fox requirementa, as per following example.

Example

In the previour example, the metal to coke ratio in a conventional

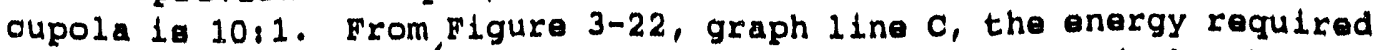
to melt 1. $2.85 \times 10^{6}$ BTU/ton. (Inoludes melt coke, bed coke and electrioal energy.)

From Figure 3-27, for conditions of $1,000^{\circ} \mathrm{F}$ hot blast, a amilar glze 48" diameter oupola lo Indloated to be oapable of melting 14.2 tong/hr. at 13,1 metal to coke ratio.

Thus reading energy required for $1000^{\circ} \mathrm{F}$ hot blast cupola at $13: 1$ metal to coke ratio, from Figure $3-25$ is:

Energy requlred $=2.20 \times 10^{6} \mathrm{BTU} / \mathrm{ton}$ BTU/ton

Reduotion in energy/ton $=(2.85-2.20) 10^{6} \mathrm{BTU} /$ ton $=650,000$

Whioh is equivalent to $\frac{0.65}{2.85}=22.88$ improvement

$\therefore$ Annual energy reduction based on 15,000 tona of metml melted

per year $=\frac{650,000 \mathrm{Bth} / \mathrm{ten} \text { melted }}{12,500 \mathrm{BTU} / 1 \mathrm{~b} \text {. }}=52 \mathrm{lba}$ coke/ton

At $\$ 0.09$ par $1 \mathrm{~b}$, cost raduation $=52 \times 15,000 \times 0.09=\$ 70,200$ par year 


\section{DIVIDED BLAST CUPOLA}

Provision of two rows of tuyeres enables higher metal tapplng temperatures to be obtalned for a given consumption of coke, or reduction of 20 to 30 percent coke with Increased melt rate of 11 to 23 percent with a given blast rate and constant tapping temperature. Comparison of thermal balances for conventional (one row of tuyeres vo. divided blast operation) is as follows:

\begin{tabular}{|c|c|c|}
\hline Item & Conventional & Dividad \\
\hline Coke charge $\#$ & 12.0 & 12.0 \\
\hline Netal temp. ${ }^{\circ} \mathrm{F}$ & 2655 & 2755 \\
\hline Top gas composition $\mathrm{CO}_{2} \%$ & 11.9 & 13.1 \\
\hline Top gas composition CO $\%$ & 15.0 & 13.0 \\
\hline Combustion ratio $\quad \mathrm{CO}_{2} \times 100$ & 44.2 & 49.8 \\
\hline Top gas temp. of ${ }^{\mathrm{CO}_{2}+\mathrm{CO}}$ & 860 & 970 \\
\hline
\end{tabular}

Ut111zation of Heat Supplied

Sensible heat in metal at Top temp. (thermal efficlency) Latent heat in top gas Sensible heat in top gas other losses

TOTAL

$\begin{array}{lll}\% & 34.7 & 35.7 \\ \% & 38.9 & 35.0 \\ \% & 12.8 & 15.1 \\ \% & \frac{13.6}{100.00} & \frac{14.2}{100.00}\end{array}$

Example

Show reduction of charge coke consumption and increase in melting rate by operating a cupola with two rows of tuyeres at a blast rate of $1,600 \mathrm{cu}$. ft/min, compared to the cupola operating under previous example conditions. At $13: 1$ metal to coke ratio, the charge coke $187.7 \%$ addition. Read Figure 3-28 for reduction of coke with two rows of tuyeres (divided blast) at $2,686^{\circ} \mathrm{F}$ metal temperature and $7.7 \%$ charge coke.

$\therefore$ From graph line (Figure 3-28) for 2 rows of tuyeres, the reduction of coke consumption $=30 \%$

Thus coke savings for divided blast cupola operation,

$=2,000 \times 0.077 \times 0.3=36.2 \mathrm{lbs} / \mathrm{ton}$ of melt

(a 12,5000 BTU/1b, energy saved per ton of melt $=46.2 \times 12,500$

- $577,500 \mathrm{BTU}$

Total energy requirements for cupola from prevlous example 18 approximately $2.20 \times 10^{6} \mathrm{BTU} /$ ton melted at $13: 1$ metal to coke ratio. 
Revised energy requirement: divided blast cupola, per ton

$=2.20 \times 10^{6}-577,500=1.62 \times 10^{6} \mathrm{BTU}$

By calculation, the new metal to coke ratio is equivalent to energy required at $15.8: 1$ metal to coke ratio or approximately 126 lbs of coke per ton of melt.

$\therefore \quad$ Annual energy reduction based on 15,000 tons of melt required per year $=577,500 \times 15,000=8662.5 \times 10^{6} \mathrm{BTU}$

$$
\begin{aligned}
& \text { Percent energy reduction }=\frac{577,500}{2.20 \times 10^{6}}=26.2 \% \\
& \text { Cost reduction for } 15,000 \text { tons per year me1t requirement } \\
& \quad=15,000 \text { tons } \times 46.2 \mathrm{lbs} / \text { ton } \times \$ 0.09 / 1 \mathrm{~b}=\$ 62,370
\end{aligned}
$$

OXYGEN ENRICHED BLAST SYSTEM

A minimum production rate of 15 tons/day and 3 days per week is generaily needed to justify the use of oxygen to gain production increase. Also no major reduction in coke usage occurs above 10 tons per hour melt rate with $2-3 \% 0_{2}$ enrichment. Savings at lower production rates are obtained as follows:

Example

Increased melting rate and/or tap temperature can be obtained by oxygen enrichment of $2-3 \%$.

The total energy required can be read from graph ' $A$ ' Figure 3-26 for production under 10 tons/hour.

Thus energy at 9 tons/hour metal melted $=1.85 \times 10^{6} \mathrm{BTU} / \mathrm{ton}$

Energy reduction compared to say a divided blast cupola (ref. Figure 3-25) with metal to coke ratio of 13.5:1 (graph "E")

$$
\begin{aligned}
& 2.20 \times 10^{6}-1.85 \times 10^{6}=350,000 \mathrm{BTU} / \text { ton } \\
& \text { Percent savings }=\frac{350,000}{2.20 \times 10^{6}}=16 \%
\end{aligned}
$$

Cost reduction based on reduction of coke $=\frac{350,000}{12,500} \mathrm{BTU} / \mathrm{lb}$

$=28 \mathrm{lbs} /$ ton melted at $\$ 0.09$ per $1 \mathrm{~b}$, the annual savings in coke energy for 15,000 tons melted $=15,000 \times 28 \times 0.09=\$ 37,800 / \mathrm{yr}$.

OVERALL ENERGY SAVINGS

The following table summarizes the possible cost and energy savings by improvements to the cupola operation. 
TABLE 3-XIX.

SUMMARY OF COST AND ENERGY SAVINGS

\begin{tabular}{|c|c|c|c|c|}
\hline ITEM & $\begin{array}{c}\text { BTU/TOM } \\
\text { SAVED }\end{array}$ & $\begin{array}{c}\text { ENERGY } \\
\text { IMPROVEMENT }\end{array}$ & $\begin{array}{c}\text { ANNUAL } \\
\text { COKE THERMS }\end{array}$ & $\begin{array}{c}\text { SAVINGS } \\
\text { COST } \$\end{array}$ \\
\hline Tap Temp. Reduction & $1,075,000$ & $30.0 \%$ & 161,250 & $\$ 116,100$ \\
Hot Blast System & 650,000 & $22.8 \%$ & 97,500 & 70,200 \\
Divided Blast System & 577,000 & $26.2 \%$ & 86,625 & 62,370 \\
$\begin{array}{c}\text { Oxyren Enrichment } \\
\text { (Not Applicable) }\end{array}$ & & - & - & - \\
\hline \multicolumn{1}{|c|}{ TOTAL } & $2,302,000$ & & 345,375 & $\$ 248,670$ \\
\hline
\end{tabular}

ECONOMIC EVALUATION

The order of magnitude cost, to implement all improvements for the sample cupola considered, is used to emphasize the viability of large capital expenditures for energy conservation measures. The payback is further improved, if full tax credits are accounted for and adjustments made for impact of future energy cost.

Example

$$
\begin{aligned}
& \text { Payback period }=\frac{\text { Capital Investment }}{\text { Energy Cost Savings/year }} \\
& \therefore \text { Payback }=\frac{\$ 1,000,000}{248,670} \quad=4.0 \text { years }
\end{aligned}
$$




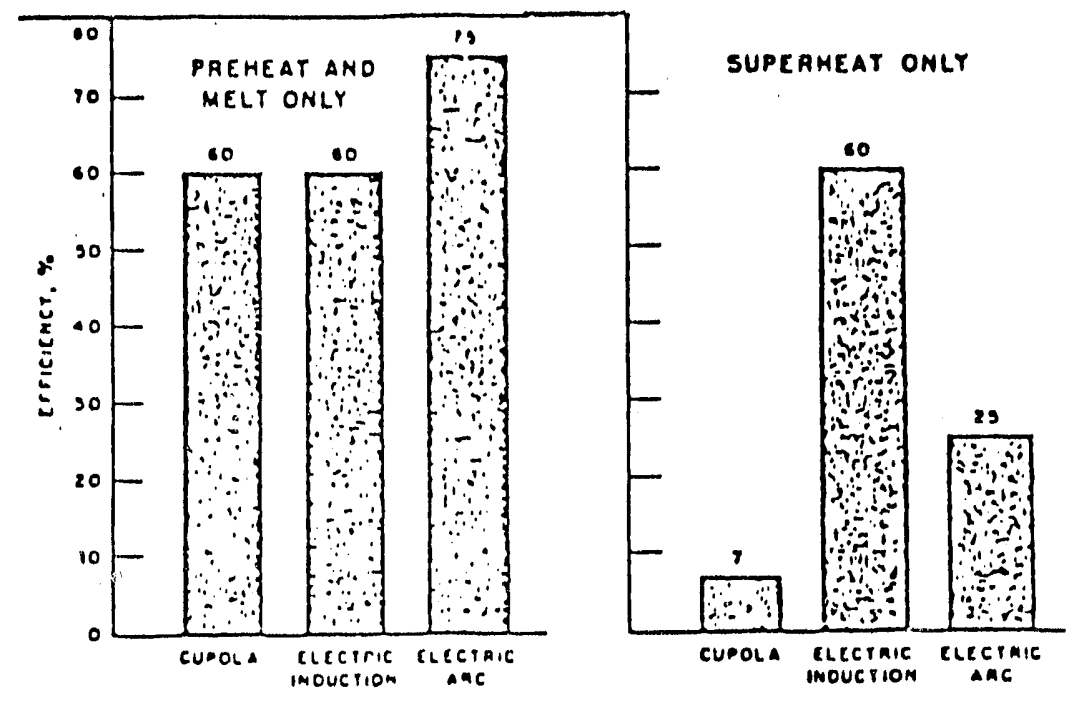

FIGURE 3-29. MELTING EFFICIENCIES

The following TABLE compares the three practical melting methods with respect to energy economics.

TABLE 3-XXI. MELTING METHOD COMPARISON

\begin{tabular}{|c|c|c|c|}
\hline ITEM & CUPOLA & $\begin{array}{l}\text { ELECT. } \\
\text { INOUCTION } \\
\end{array}$ & $\begin{array}{l}\text { ELECT. } \\
\text { ARC. }\end{array}$ \\
\hline $\begin{array}{l}\text { Cost to preheat } \\
\text { Cost to melt } \\
\text { Cost to superheat } \\
\text { TOTAL }\end{array}$ & $\begin{array}{r}58.01 \\
2.71 \\
13.74 \\
24.46\end{array}$ & $\begin{array}{r}513.99 \\
4.73 \\
2.80 \\
521.52\end{array}$ & $\begin{array}{r}\$ 11.19 \\
3.79 \\
6.72 \\
521.70\end{array}$ \\
\hline BTU's required $\times 10^{6}$ & 3.65 & 1.84 & 1.85 \\
\hline
\end{tabular}

\section{Example}

Cost to pre-heat one ton of metal by cupola to melt temperature;

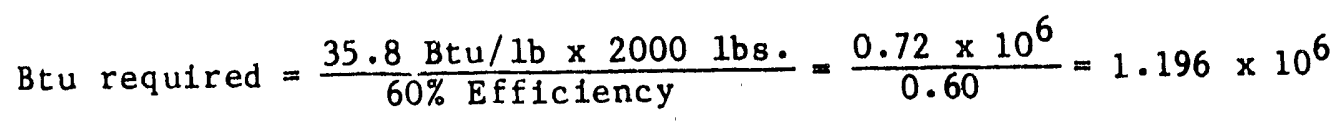

Cost of energy @ $\$ 6.70 / \mathrm{m} 111$ ion Btu $=1.196 \times 6.70=\$ 8.01$

On the basis of this analysis, the electric induction furnace is more energy efficient. However, the analysis can be applied to any combination of melting methods to obtain the most energy cost effective results (See Figure 3-29). 
COMPARATIVE ANAIYSIS

Determining the best method involves consideration of a complex interrelationship of specific foundry neede, relative to furnace operation. Energy for melting 1o only one aspect and not necesaarliy the primary factor, however, this analysis deals with differences in costs of melting due to energy only.

Based on calculated cost of energy developed elsewhere in this study, the cost of potential heat by alternate methods is summarized as follows:

TABLE 3-XV.

COST SUMMARY - COKE AND ELECTRICITY

\begin{tabular}{|l|c|c|}
\hline Item & Foundry Coke & Electricity (Ave.) \\
\hline Cost of Energy & $\$ 167.50 /$ net ton $*$ & $\$ 0.0400 / \mathrm{KW} . *$ \\
Potential Heat & \\
Content & $12500 \mathrm{Btu} / \mathrm{lb}$. & $3415 \mathrm{Btu} / \mathrm{KWH}$ \\
Cost per million & & $\$ 11.70$ \\
Btu & $\$ 6.70$ & $\$$ \\
\hline
\end{tabular}

* representative values

Energy for pre-heating, melting and superheating 1 ton of cast iron to $2,7000 \mathrm{~F}$.

$552 \mathrm{Btu} / 1 \mathrm{~b} \times 2000=1,100,000 \mathrm{Btu} /$ ton

Percent of energy requirement for each phase of the melting cycle is as follows:

Btu/1b.

Pre-heat to melt temp.

552 Btu/1b $\times 65 \%=358.8$

Melt to liquid state

$552 \mathrm{Btu} / 1 \mathrm{~b} \times 228=121.4$

super heat to $2,700^{\circ} \mathrm{F}$

552 Btu $/ 1 b \times 1.38=71.8$

For melting efficiencies of different types of equipment used for melting cast iron (see Figure 3-29). 


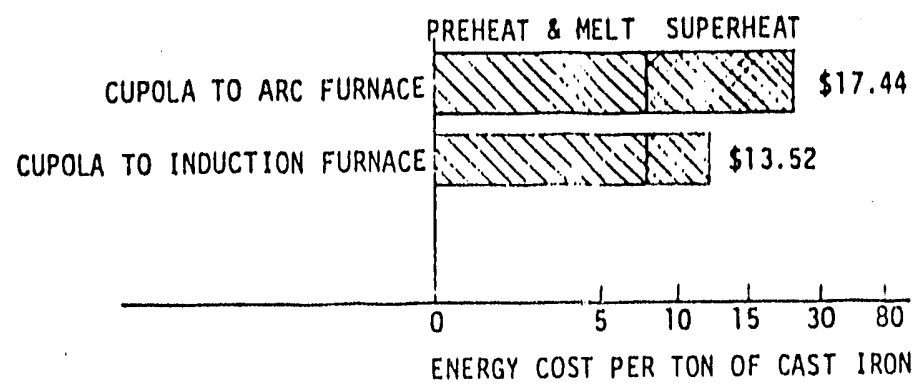

FIGURE 3-30. ENERGY COST COMPARISON FOR MELTING AND HOLDING

Subject to the practical feasibility of these combinations and not accounting for other capital or operating costa, the cupola to induction furnace approach at $\$ 13.52$ per ton melted is the least cost. Btu's required by this method based on previous calculations are:

$$
\begin{array}{ll}
\text { Cupola } & 1.60 \times 10^{6} \\
\text { Induction } & \frac{0.24 \times 10^{6}}{\text { TOTAL }} \\
& 1.84 \times 10^{6} \mathrm{Btu} / \text { ton }
\end{array}
$$

Note: As mentioned in section 2, a cost analysis computer model to evaluate cupola ve. electric melting is avallable through the EPRI Center for Materials Production. 
GENERAI

Furnace charge preheating, up to $1000^{\circ} \mathrm{F}$ for lron or steel, regults in energy and cost reductions of up to 258 .

This section deals with charge preheating by:

- Gas-fired burner units.

- Oxygen assisted burners.

Diagrame and tables indicate typlcal data and performance for equipment commercially avallable. Similar information should be reviewed from alternate sources prior to actual energy audit work being carried out.

\section{Example}

Required: Scrap preheat temperature of $1,000^{\circ} \mathrm{F}$ for butcher of one ton size to be charged to an electric melting unit, operating 2 hours per day, 240 days per year at annual rate of say 3,000 tons of gray iron.

Increased melt production percentage is obtained by reference to Figure $3-31$, reading for 'iron' at $1,000^{\circ} \mathrm{F}$ scrap temperature.

e $1,000^{\circ} \mathrm{F}$, resulting increase $=308$

Equivalent Energy Requirementg:

Natural Gas-Fired Unit:

e $1,000^{\circ} \mathrm{F}=600 \mathrm{cu}$. ft $/$ ton $=600,000 \mathrm{Btu}$ (from Table $3-\mathrm{XXII}$ ).

Thus: Cost $\mathrm{\$}$ : $30 /$ Therm $\times 6$ Therms $=\$ 1.80 /$ ton

Electrical Energy Ugage Reduction

e $1,000^{\circ} \mathrm{F}=117 \mathrm{~kW} /$ ton (from Table $3-\mathrm{XXII}$ ).

Thus: Cost $\$ 0.042$ per $k W=\$ 4.91 /$ ton

Net cost savings $=(4.91-1.80)=\$ 3.11$ per ton

Annual cost reduction $=3,000 \times 3.11=\$ 9,330$ 


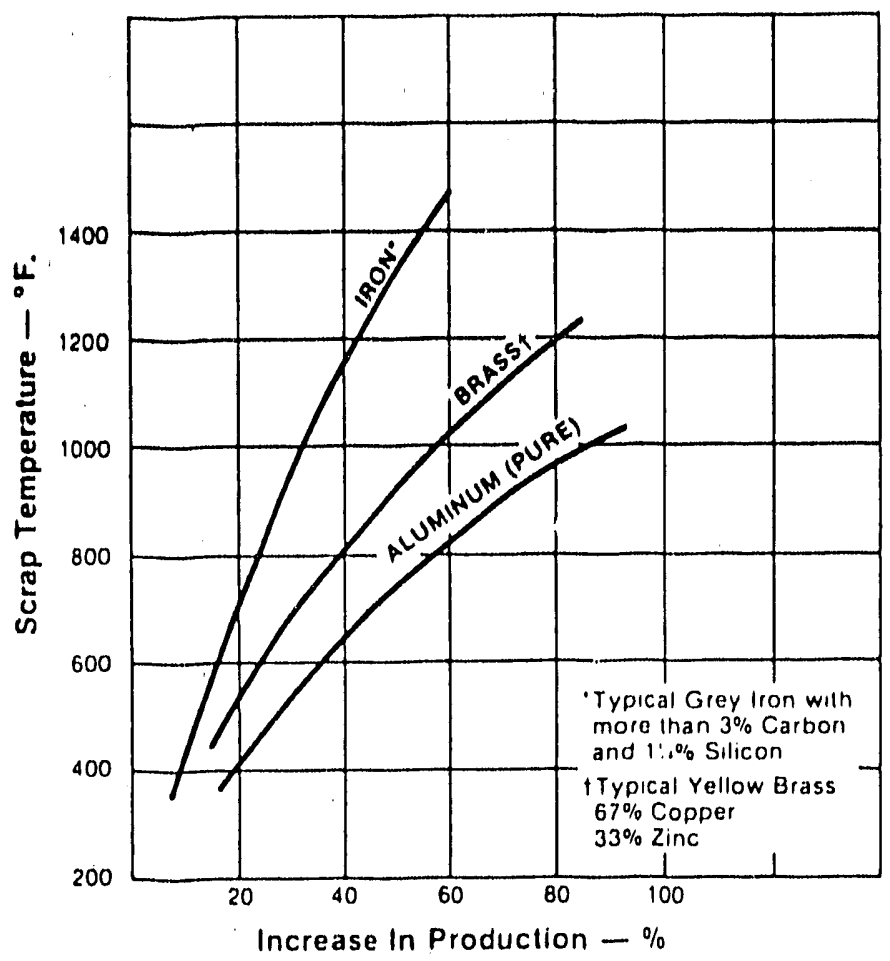

FIGURE 3-31. INCREASED MELT PROLÜCTION

TABLE 3-XXII.

Furnace Charge Preheating Energy Comparison for Arc and Induction Melting of Iron, Aluminum and Brass

Elficiency Basis: Induction Furnace@ 00\%/Fuel (Gas, Propane, Oil @ 47\% 10 93\%, depending on Temperalure).

\begin{tabular}{|c|c|c|c|c|c|c|c|c|c|c|c|c|}
\hline \multirow[t]{2}{*}{$\begin{array}{l}\text { Preheal } \\
\text { Temp. 'f. }\end{array}$} & \multicolumn{3}{|c|}{$\begin{array}{c}\text { KW Usage per Ton } \\
\text { Cold Mell }\end{array}$} & \multicolumn{3}{|c|}{$\begin{array}{c}\text { Venella Usage per Ton/CF } \\
\text { Nalural Gas } \\
\text { (a) } 1000 \text { BiU/Cu. Fl. }\end{array}$} & \multicolumn{3}{|c|}{$\begin{array}{c}\text { Venella Usage pet Ton/Gal. } \\
\text { Propane } \\
\text { (a) } 91,735 \text { Bru/Gal. }\end{array}$} & \multicolumn{3}{|c|}{$\begin{array}{c}\text { Venella Usage pet Ton/Gal. } \\
\text { "1 or M2 Fuel Oil } \\
\text { 158.000 BTU/Gal. }\end{array}$} \\
\hline & Iron & Alum & Brass & Iron & Alum & Brass & lron & Alum & Biass & Iron & Alum & Buass \\
\hline 500 & 59 & 101 & 44 & 150 & 256 & 105 & 164 & 28 & 114 & 11 & 19 & 8 \\
\hline 600 & 70 & 121 & 53 & 216 & 365 & 151 & 2.4 & 40 & 165 & 16 & 26 & 11 \\
\hline 700 & 82 & 141 & 62 & 276 & 469 & 193 & 30 & 50 & 2.1 & 20 & 34 & 14 \\
\hline 800 & 94 & 161 & 70 & 372 & 640 & 261 & 41 & 70 & 28 & 27 & 46 & 19 \\
\hline 900 & 106 & 181 & 79 & 480 & 808 & 332 & 52 & 88 & 36 & 35 & 59 & 24 \\
\hline 1000 & 117 & 201 & 89 & 600 & 1012 & 117 & 65 & 110 & 45 & 43 & 73 & 30 \\
\hline 1100 & 129 & & & 792 & & & 86 & & & 57 & & \\
\hline 1200 & $1+1$ & & & 1008 & & & 110 & & & 73 & & \\
\hline 1300 & 152 & & & 1320 & & & 144 & & & 96 & & \\
\hline 1400 & 164 & & & 1680 & & & 183 & & & 122 & & \\
\hline
\end{tabular}


Oxy-fuel aseisted melting involves supplying additional heat energy during melt down by introducing oxygen with the fuel to supplement or replace the electrical power input to the furnace. oxy-fuel asalated meiting practice has been applied ouccessfully to most nonferxous and ferrous metals with the exception of brass which exhibits high zinc loss. sultable stolchiometric firing rates are chosen for each metal to minimize oxidation.

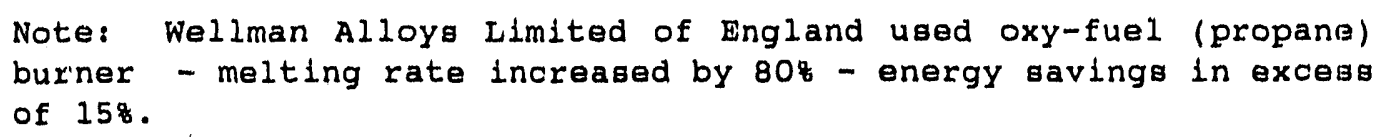

Example

Data based on various induction furnaces incorporating oxy-fuel indicates average of 268 improvement in power input, reference Table 3-XXIII.

TABLE 3-XXIII. OXY-FUEL ASSISTED MELTING IN INDUCTION FURNACES

\begin{tabular}{|c|c|c|c|c|c|c|c|c|c|c|c|c|c|c|}
\hline \multicolumn{6}{|c|}{$\begin{array}{l}\text { Dole Obleined Fram Varloue Induellon Furnaces } \\
\text { Incorpololing Ory. Fual }\end{array}$} & \multicolumn{3}{|c|}{$\begin{array}{l}\text { Moll Down Time } \\
\text { Tap lo Tap. MIn. }\end{array}$} & \multicolumn{3}{|c|}{$\begin{array}{l}\text { Fuinece Elocitical } \\
\text { Pow ot Input kwhition. }\end{array}$} & \multicolumn{3}{|c|}{$\begin{array}{l}\text { Molling Raled } \\
\text { Ion/he }\end{array}$} \\
\hline Call & $\begin{array}{l}\text { Furnace } \\
\text { Copocely } \\
\text { Ton nol }\end{array}$ & $\begin{array}{c}\text { Furnoce } \\
\text { Aelling } \\
k=0\end{array}$ & $\begin{array}{l}\text { Melertal } \\
\text { Moned }\end{array}$ & Fuel & 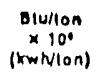 & Normal & Alolinted & $\underset{\substack{\text { Improve } \\
\text { monl }}}{ }$ & Normal & Aocleted & 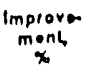 & Hormal & Aoclotod & 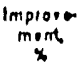 \\
\hline 1 & (20s) & 200 & $\begin{array}{l}\text { Duetile } \\
\text { Iron }\end{array}$ & Propane & $\begin{array}{l}773 \\
(221)\end{array}$ & נד & si & 30 & 897 & 020 & 30 & .240 & .034 & 4 \\
\hline 2 & $i^{3}(x)$ & 150 & $\begin{array}{l}\text { NiCr } \\
\text { Nloy }\end{array}$ & Prapene & $\infty$ & 150 & OS & 30 & 1040 & 120 & 31 & .20 & 210 & so \\
\hline I & $(1010)$ & 300 & $\begin{array}{l}\text { Carion } \\
\text { Siool }\end{array}$ & Propene & $\begin{array}{l}.3175 \\
(03)\end{array}$ & 150 & 105 & 30 & 015 & 000 & 17 & .42 & .60 & 4] \\
\hline $4^{\circ}$ & $\begin{array}{l}1.0 \\
(1010)\end{array}$ & 300 & $\begin{array}{l}\text { NICl } \\
\text { Allay }\end{array}$ & Propane & .025 & 184 & 87 & 47 & 1003 & 300 & 42 & .325 & .812 & as \\
\hline 1 & $\begin{array}{l}10 \\
(1011)\end{array}$ & 600 & $\begin{array}{l}\text { NICA } \\
\text { Nloy }\end{array}$ & Bulane & $\begin{array}{l}.592 \\
\text { (11) }\end{array}$ & 90 & $\infty 0$ & 33 & 73 & 030 & 11 &.$\infty$ & .00 & II \\
\hline 0 & $\begin{array}{l}20 \\
(2000)\end{array}$ & $\infty \infty$ & $\begin{array}{l}\text { Alloy } \\
\text { Slool }\end{array}$ & Nal, Cal & $\begin{array}{l}.503 \\
(14 t)\end{array}$ & 175 & 133 & 23 & 178 & 810 & 22 & .61 & 1.0 & 41 \\
\hline 1 & $\begin{array}{l}30 \\
\text { (20) } 11\end{array}$ & $\infty \infty$ & $\begin{array}{l}\text { Gior } \\
\text { lion }\end{array}$ & Propeno & $\begin{array}{l}730 \\
12141\end{array}$ & 100 & 123 & 34 & 170 & 625 & 32 & .002 & .070 & st \\
\hline 1 & 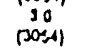 & $\infty \infty$ & $\begin{array}{l}\text { giar } \\
\text { lion }\end{array}$ & Propene & $\begin{array}{l}.297 \\
(07)\end{array}$ & os & $n$ & 3 & $B 80$ & 471 & 10 & .840 & 1.384 & 12 \\
\hline Casto & $\begin{array}{l}\text { Fouros: } \\
\text { Courtesy } \\
\text { slourbic }\end{array}$ & $\begin{array}{l}\text { ind Resu } \\
\text { Welimar } \\
\text { got Wos }\end{array}$ & 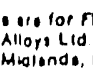 & $\begin{array}{l}\text { Tol. Butro } \\
\text { Ambleco } \\
\text { England. }\end{array}$ & & $\begin{array}{l}\text { Avoroge } \\
\text { impiove } \\
\text { meni }\end{array}$ & & 24.9 & $\begin{array}{l}\text { Averege } \\
\text { Improve } \\
\text { ment }\end{array}$ & & 20 & $\begin{array}{l}\text { Arelage } \\
\text { Implove } \\
\text { mont }\end{array}$ & & 48 \\
\hline
\end{tabular}

Extracted from Foundry H \& T MPS - March 1978

by J. Allread / Grede foundries, Milwaukee 
SECTION 4

ENERGY AUDIT FORMS

A. ENERGY USE TABLES AND PRODUCTION STATISTICS

4-1 


\section{ELECTRICAL POWER USAGE}

\begin{tabular}{|c|c|c|c|c|c|c|c|c|}
\hline BILLING PERIOD & ENERGY KWH & $\begin{array}{l}\text { BILLING } \\
\text { DEMAND }\end{array}$ & $\begin{array}{l}\text { POWER } \\
\text { FACTOR }\end{array}$ & $\begin{array}{l}\text { ENERGY } \\
\text { CHARGE }\end{array}$ & $\begin{array}{c}\text { FUEL } \\
\text { ADJUSTMENT } \\
\text { CHARGE }\end{array}$ & $\begin{array}{l}\text { DEMAND } \\
\text { CHARGE }\end{array}$ & $\begin{array}{c}\text { GROSS } \\
\text { BILL. }\end{array}$ & NET BILL \\
\hline \multicolumn{9}{|l|}{ JANUARY } \\
\hline \multicolumn{9}{|l|}{ FEBRUARY } \\
\hline \multicolumn{9}{|l|}{ MARCH } \\
\hline \multicolumn{9}{|l|}{ APRIL } \\
\hline \multicolumn{9}{|l|}{ MAY } \\
\hline JUNE & & & & & & & & . \\
\hline \multicolumn{9}{|l|}{ JULY } \\
\hline \multicolumn{9}{|l|}{ AUGUST } \\
\hline \multicolumn{9}{|l|}{ SEPTEMBER } \\
\hline \multicolumn{9}{|l|}{ OCTOBER } \\
\hline \multicolumn{9}{|l|}{ NOVEMBER } \\
\hline \multicolumn{9}{|l|}{ DECEMBER } \\
\hline TOTALS & & & & & & & & \\
\hline
\end{tabular}

AVERAGE POWER COST \$

$=\$$ / K!!H

\section{REMARKS:}


ANNUAL GAS CONSUMPTION

\begin{tabular}{|l|l|l|l|}
\hline PERIOD & THERMS & BTU $\times 10^{6}$ & COST \\
\hline & & & \\
\hline & & & \\
\hline & & & \\
\hline & & & \\
\hline & & & \\
\hline & & & \\
\hline & & & \\
\hline & & & \\
\hline
\end{tabular}

HEAT CONTENT OF GAS = BTU/CU FT (FROM BILL)

100,000 BTU $=1$ THERM

COST OF GAS $=\$$ THERMS $=\$$ PER THERM

REMARKS: 
ANNUAL COKE CONSUMPTION

\begin{tabular}{|l|l|l|l|}
\hline PERIOD & TONS & BTU $\times 10^{6}$ & COST \\
\hline & & & \\
\hline & & & \\
\hline & & & \\
\hline & & & \\
\hline & & & \\
\hline & & & \\
\hline & & & \\
\hline & & & \\
\hline & & & \\
\hline
\end{tabular}

AVERAGE COST OF COKE $=\$$

\section{TONS}

PER TON

$1 \mathrm{LB}$, OF COKE $=12,500 \mathrm{BTU}$

REMARKS: 
ANNUAL OIL CONSUMPTION

\begin{tabular}{|l|l|l|l|}
\hline PERIOD & GALLONS & BTU $\times 10^{6}$ & COST \\
\hline & & & \\
\hline & & & \\
\hline & & & \\
\hline & & & \\
\hline & & & \\
\hline & & & \\
\hline & & & \\
\hline & & & \\
\hline
\end{tabular}

AVERAGE COST OF OIL $=\$$

GALLONS

PER GALLON

REMARKS:

FORM 4-4 
ANNUAL PROPANE CONSUMPTION

\begin{tabular}{|l|l|l|l|}
\hline PERIOD & GALLONS & BTU $\times 10^{6}$ & COST \\
\hline & & & \\
\hline & & & \\
\hline & & & \\
\hline & & & \\
\hline & & & \\
\hline & & & \\
\hline & & & \\
\hline & & & \\
\hline
\end{tabular}

REMARKS:

FORM $\quad 4-5$

$4-6$ 
YEAR

METAL CAST

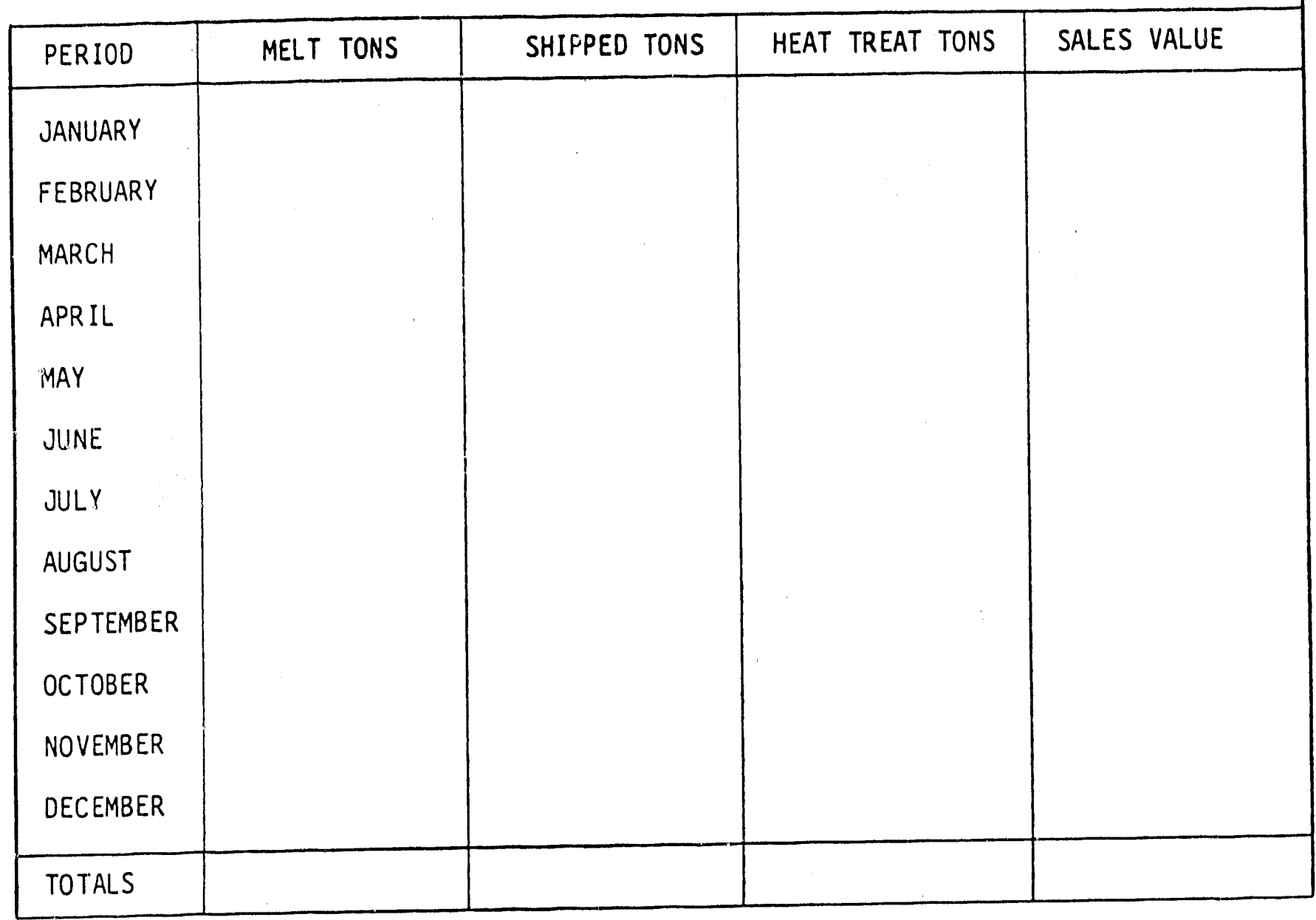

AVERAGE MELT TONS/DAY =

REPORTED \% SCRAP

REPORTED \% MELT LOSS

AVERAGE FOUNDRY YIELD $\%$

FORM A-6 
PLANT EQUIPMENT HORSEPOWER LIST

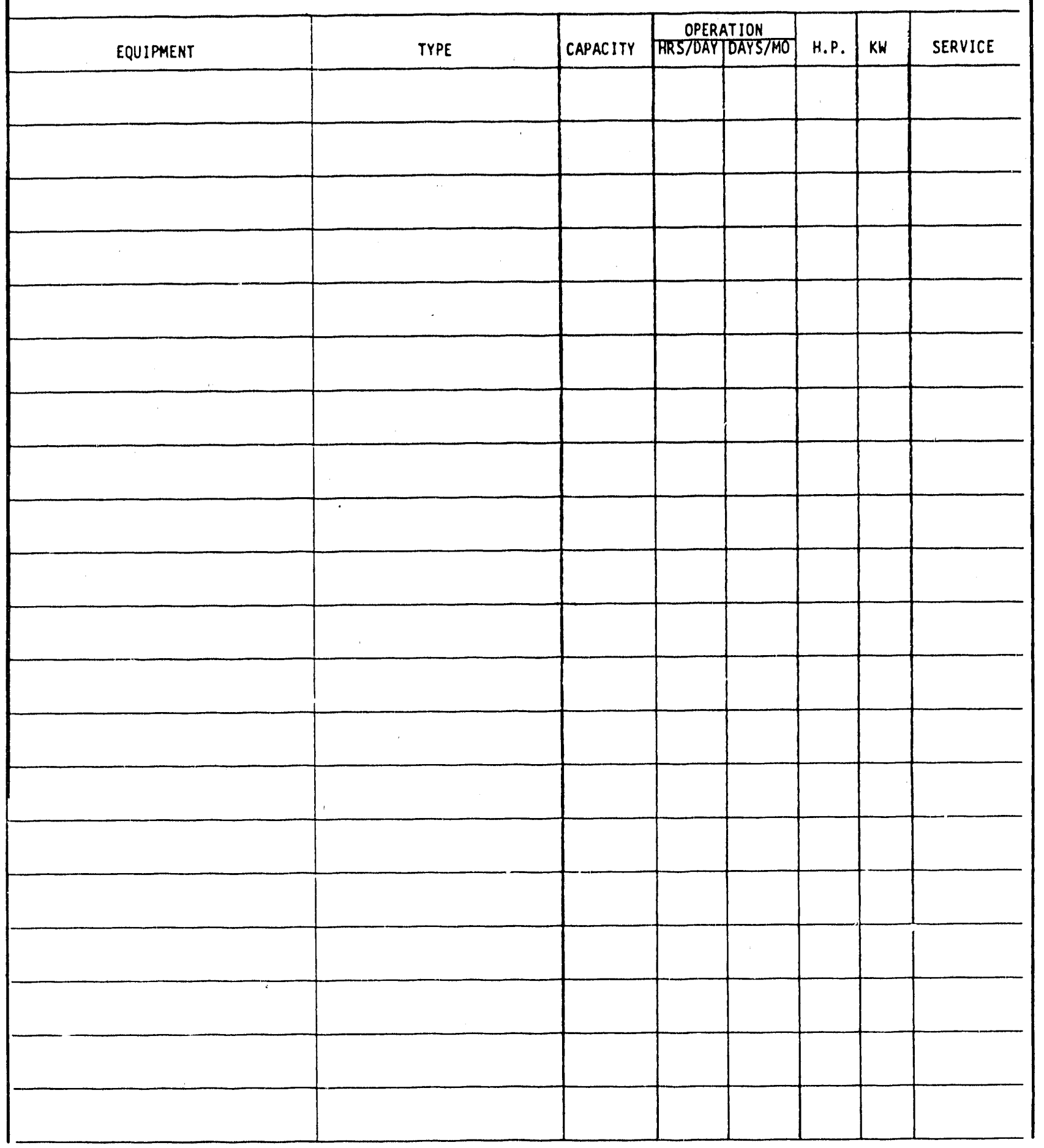

FORM 4-7 
DESCRIPTION AND FLOW RATES OF GAS-FIRED EQUIPMENT

\begin{tabular}{|c|c|c|c|c|c|c|c|}
\hline \multirow[b]{2}{*}{ EQUIPMENT } & \multirow{2}{*}{ TYPE } & \multicolumn{2}{|c|}{ BURNERS } & \multicolumn{2}{|c|}{ OPERATION } & \multirow{2}{*}{$\begin{array}{c}\text { AVERAGE } \\
\text { CFH }\end{array}$} & \multirow{2}{*}{$\begin{array}{c}\text { MAXIMUM } \\
\text { CFH }\end{array}$} \\
\hline & & No. & TYPE & HRS/DAY & DAYS/MO & & \\
\hline & & & & & & & \\
\hline & & & & & & & \\
\hline & & & & & & & \\
\hline & & & & & & & \\
\hline & & & & & & & \\
\hline & & & & & & & \\
\hline & & & & & & & \\
\hline & & & & & & & \\
\hline & & & & & & & \\
\hline & & & & & & & \\
\hline & & & & & & & \\
\hline & & & & & & & \\
\hline & & & & & & & \\
\hline
\end{tabular}

FORM 4-8 


\section{PRESENT ENERGY-EFFICIENCY RECORD}

MONTH OR YEAR RECORDED

UNITS OF PRODUCTIOH

FUEL COSTS

- Electricity

- Natural Gas

- Propane

- 0 il

- Coke

- Other

s

TOTAL

ENERGY USED

- $\mathrm{KNH}$

3,412 Btu

$B$ Bu $\times 10^{6}$

- Mcf gas

$x \quad y$

- Gal. Propane

$\times 91,600 \mathrm{Btu}$

- Gal. 011

$\times 140,000$ Btu

- coke - lb.

$\times \quad 12,500$ Btu

TOTAL BTU

ENERGY USED PER UNIT OF PRODUCTION

(Million Btu)

Btu $\times 10^{6} /$ Ton (Units)

COST PER MILLION BTU

(Energy Cost)

Million Btu)

$\cos t / B \operatorname{tu} \times 10^{6}$

COST PER UNIT OF PRODUCTION

(Total Cost)

(Units)

$\cos t /$ Unit

I/ I Mcf = 1,000 cu.ft./hr - See Gas Bill for Btu contenl/cu.ft.

FORM 4-9

$$
4-10
$$




\section{POTENTIAL ENERGY-EFFICIENCY RECORD}

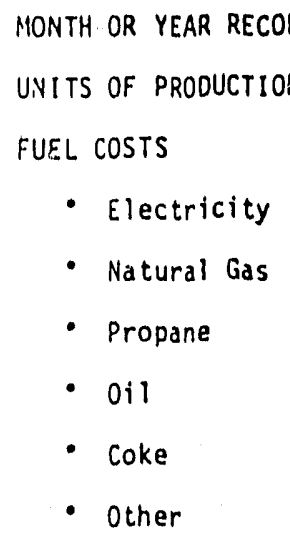

\section{\$}

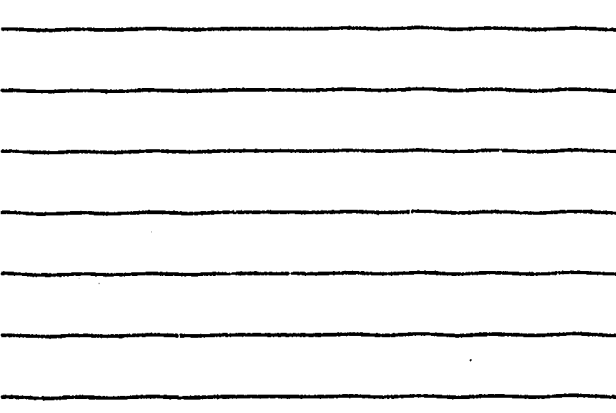

ENERGY USED

- KWH x 3,412 Btu

Btu $\times 10^{6}$

- Mcf gas

$x$

- Gal. Propane

$\times 91,600$ Btu $=$

- Gal. oil

$\times 140,000$ Btu

- Coke - lb.

$\times \quad 12,500 \mathrm{Btu}$

-

TOTAL BTU

ENERGY USED PER UNIT OF PRODUCTION

(Million Btu) (Units)

Btu $\times 10^{6} /$ Ton

COST PER MILLION BTU

(Energy cost)

(iifilion Btu)

$\cos t / 8 \operatorname{tu} \times 10^{6}$

COST PER UNIT OF PROOUCTION

(Total $\cos t)$

(Units)

Cost/Unit

1/ 1 Mcf = 1,000 cu.ft./hr - See Gas Blll for Btu content/cu.ft.

FORM $\quad 4-10$ 
B. OPERATIONAL DATA FACT SHEETS

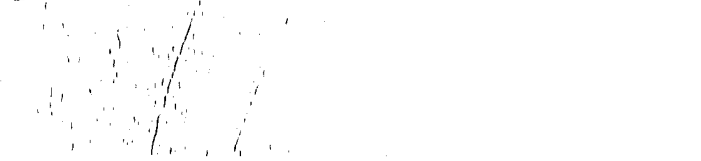

4-12 


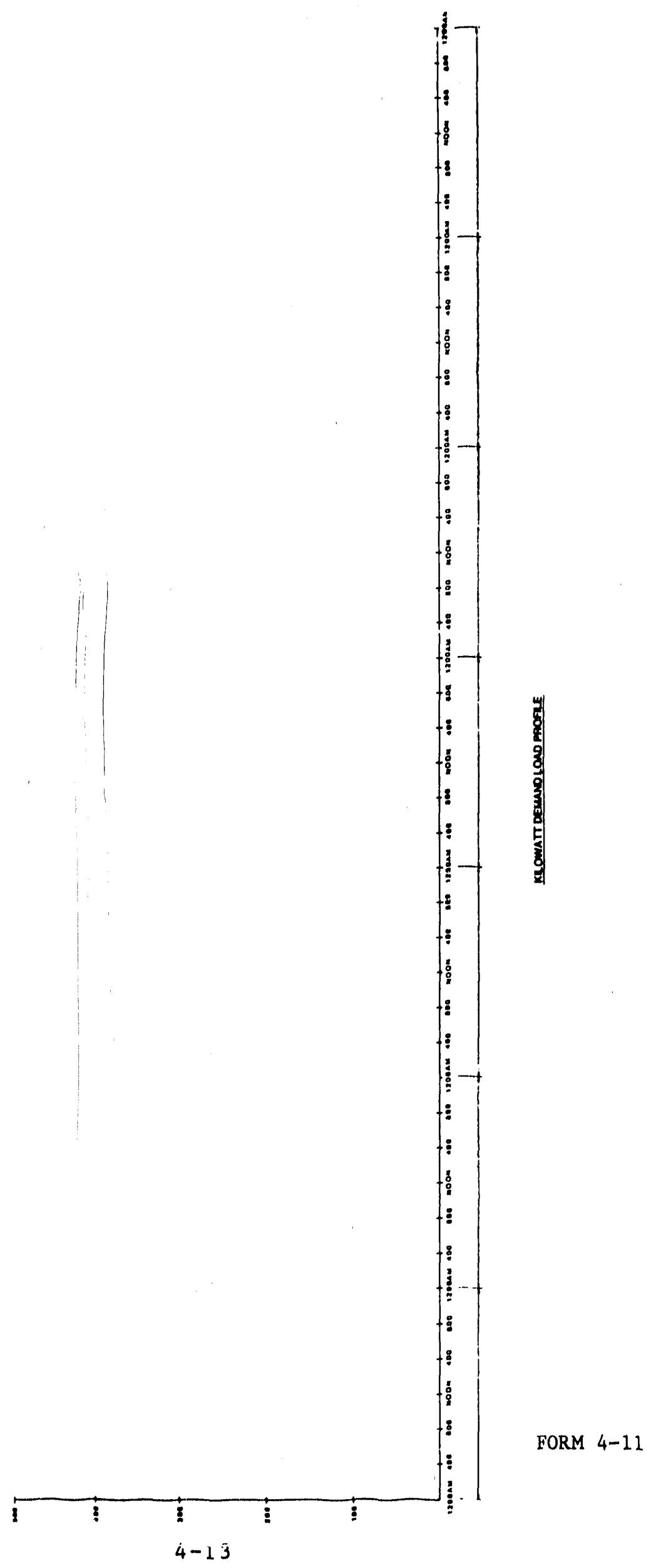



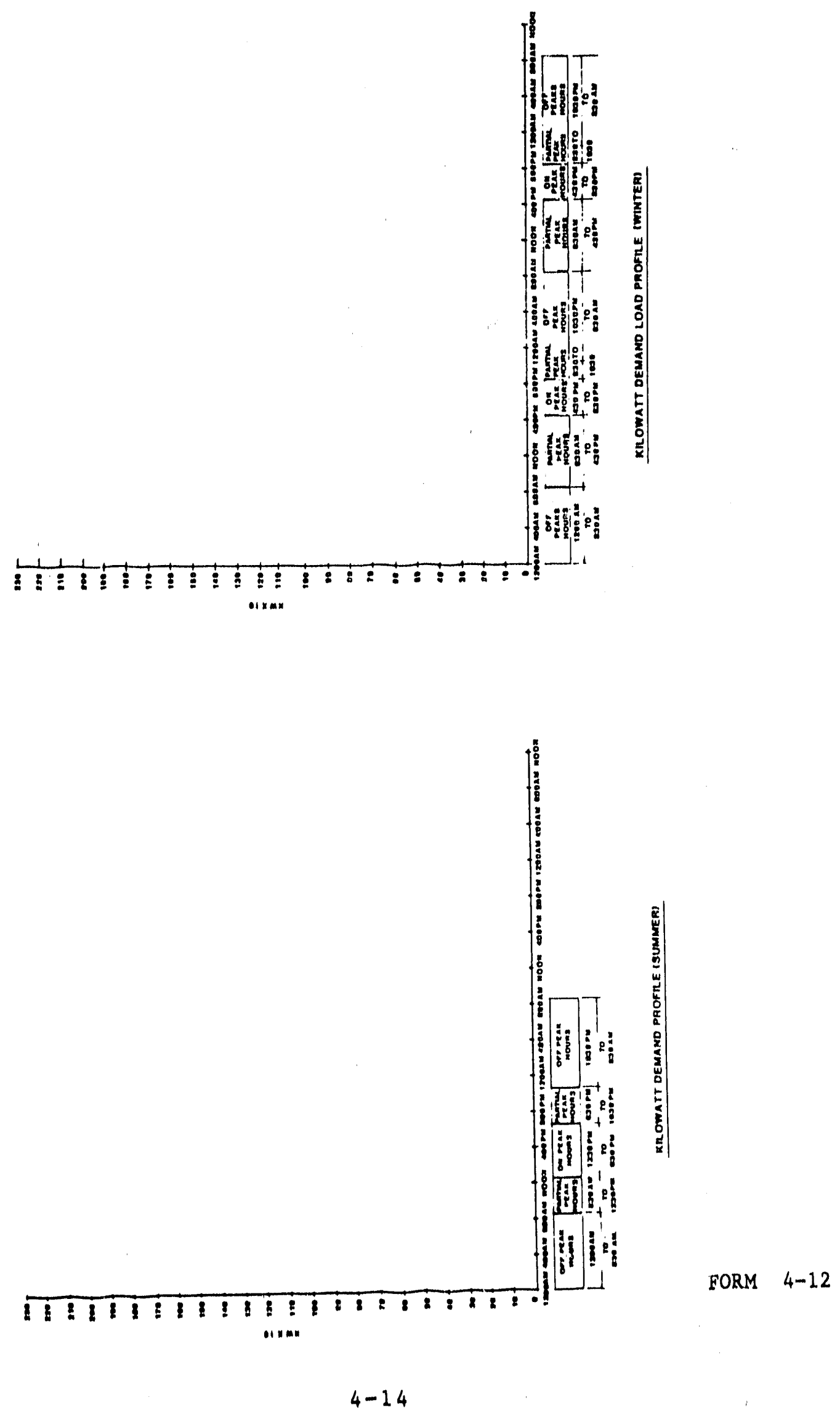


\section{OPERATIONAL DATA FACT SHEET}

ARC FURNACE DATA

Furnace make

Model

Shell Dia.

Bath Depth

FEET

Capacity INCHES TONS
Electrode Dia. Transformer

Primary.

Taps 1st 2nd $3 r d$ Ton/YR

Output

A110y

Melt cycle minutes

Heat size tons

Heats per day

Temperature

No. of Back charges

No. of slag cycles

Blow down cycle $\mathrm{O}_{2}$ ${ }^{\circ} \mathrm{F}$

Type of fume collection:

Furnace pressure oz

Exhaust CFM

Water Cooling GPM

Roof , Glan , Slag Door Bazel

Water temperature in ${ }^{\circ} \mathrm{F}$, out of

Type of refractory ining.

REMARKS :

Form 4-13 
OPERATIONAL DATA FACT SHEET

CORELESS INDUCTION FURNACE

Furnace make Transformer KVA

Mode1 Primary Voltage

Capacity Secondary Voltage

Output tons/yr. tons/day

Alloy

Melt cycle minutes

Tap Quantity lbs.

Charge Quantity lbs.

Tap temperature ${ }^{\circ} \mathrm{F}$

Holding temperature ${ }^{0} \mathrm{~F}$

Slag cycle minutes

Fume collection CFM Water cooling....GPM. Temp........ in ${ }^{{ }^{\circ}} \mathrm{F} . \ldots$. . out ${ }^{\circ} \mathrm{F}$

Type of Refractory

Energy consumption KWH/YR

Energy Cost f $/ \mathrm{KW}$

REMARKS: 
Metal type:

Pouring or tap temperature

Heat content Btu/1b

Melting period hrs.

METHOD OF MELTING

Metal melted/hr.lbs.

Burner rating Btu/hr

Total gas usage/hr

Capacity of furnace lbs .

Crucible diameter

Area of metal radiation sq.ft.

Area of refractory wall:

Below metal

Above metal

Thickness of wall

Door open area or dip well sq.ft.

Mean temperature of walls ${ }^{\circ} \mathrm{F}$

Outer temperature of walls $\mathrm{T}_{1}$

Inner temperature of wils $\mathrm{T}_{2}$

Present refractory $K$ value

Proposed refractory $K$ value

Rs value for refractory

$\mathrm{CO}_{2}$ flue gas reading

Combustion air cfm

Combustion air wg

Flue gas (or comb.) temperature

Ambient temperature ${ }^{\circ} \mathrm{F}$

Time of day used

Days/year used

Energy cost/therm \$
Annual tons

${ }^{\circ} \mathrm{F}$

Shifts/day

Holding period hrs.

CRUCIBLE

REVERB
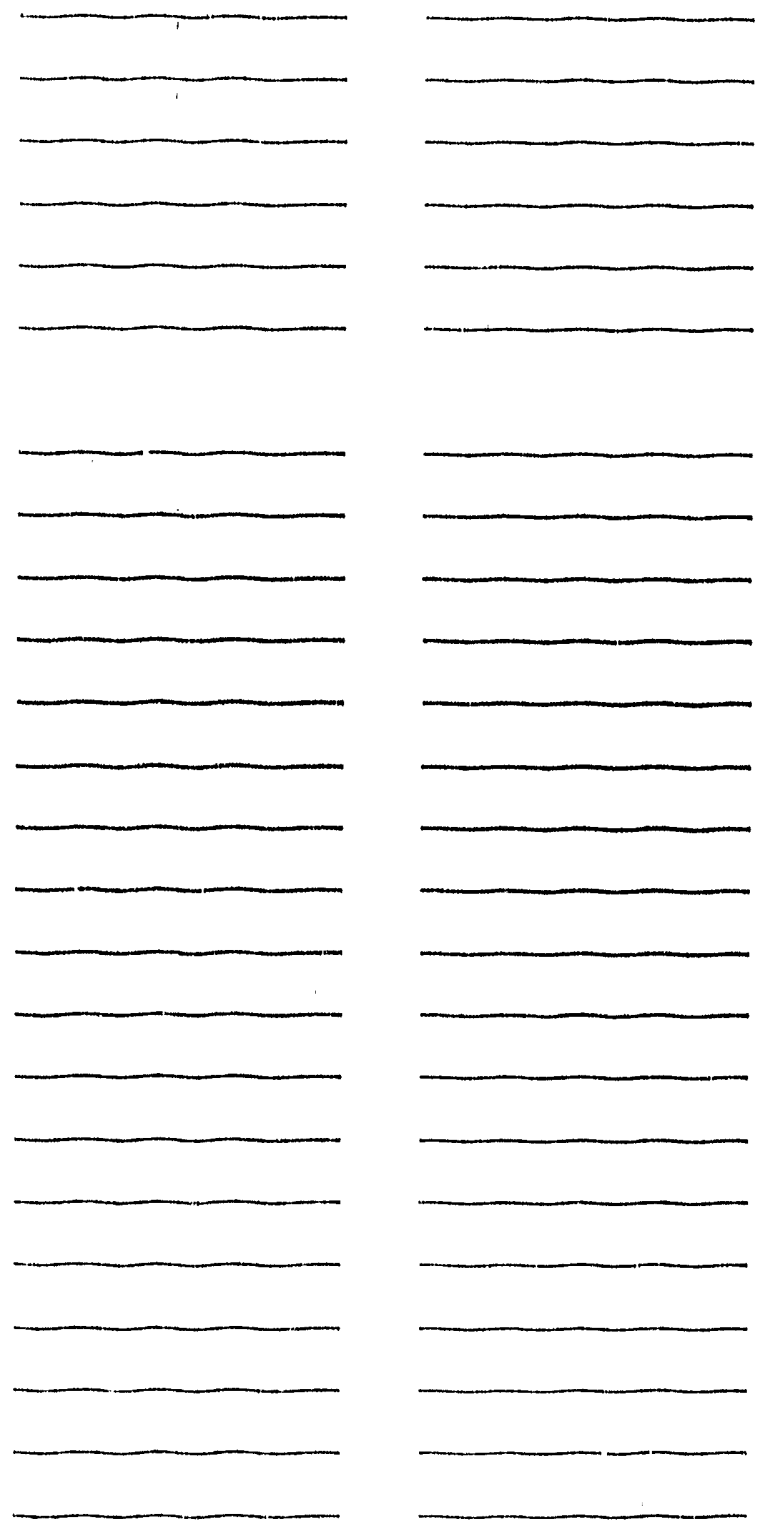

FORM 4-15 


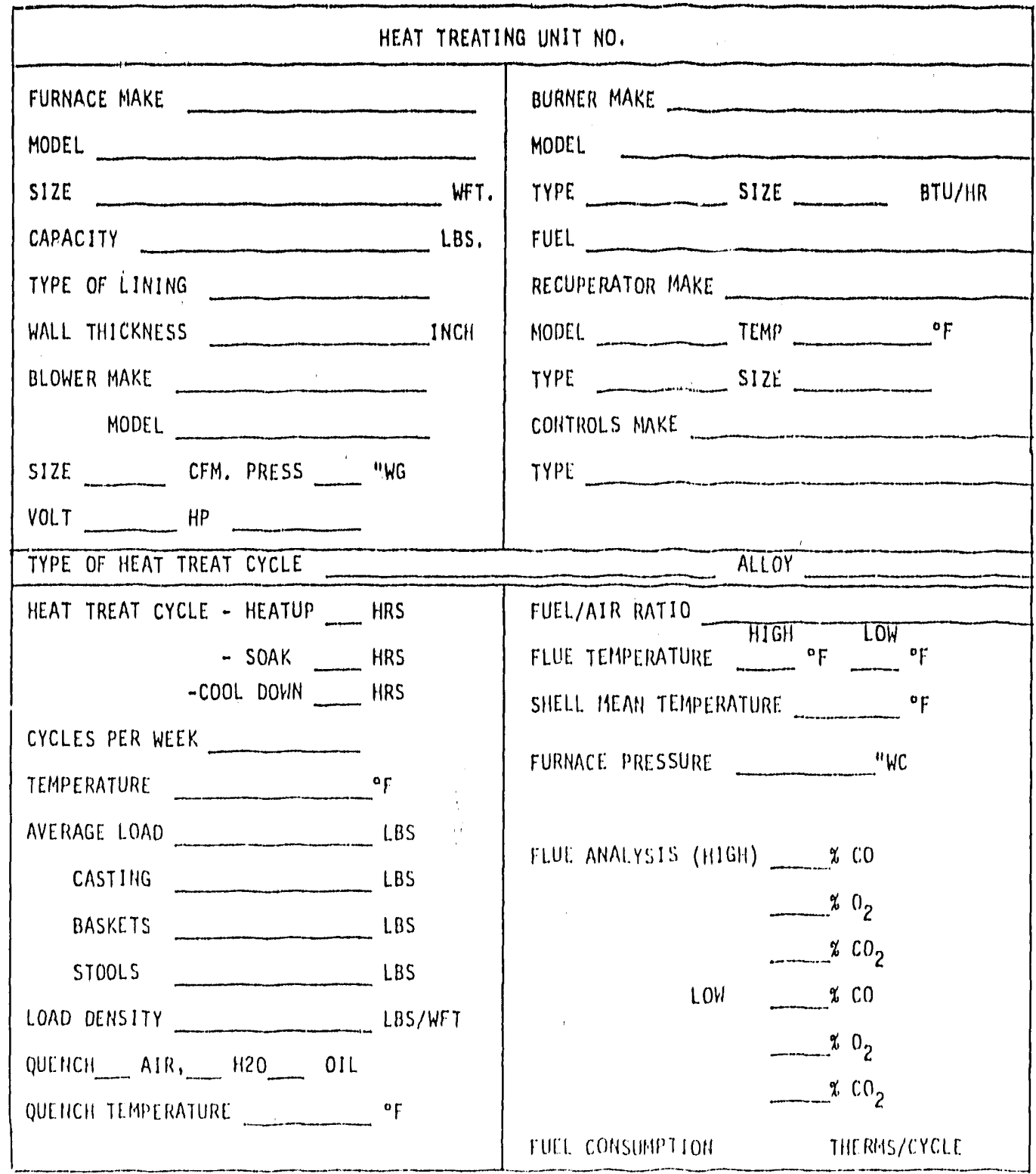

WALL AREA SQ.RT.

WALL TEMPIRATIJRT HOT IACE T, of

haLL temPIRATURE COLD IACE $T_{2}$ "T

AMBIENT TLMPLRATURE. 01

EXTIRIAL SURIACE AREA SQ.TT.

[HERGY COST/THERM \$

HLAT TREAT LOADS/DAY

HEAT TREAT LOADS/YEAH

FORM $4-16$ 
OPERATIONAL DATA FACT SHEET

BURN -OUT FURNACES

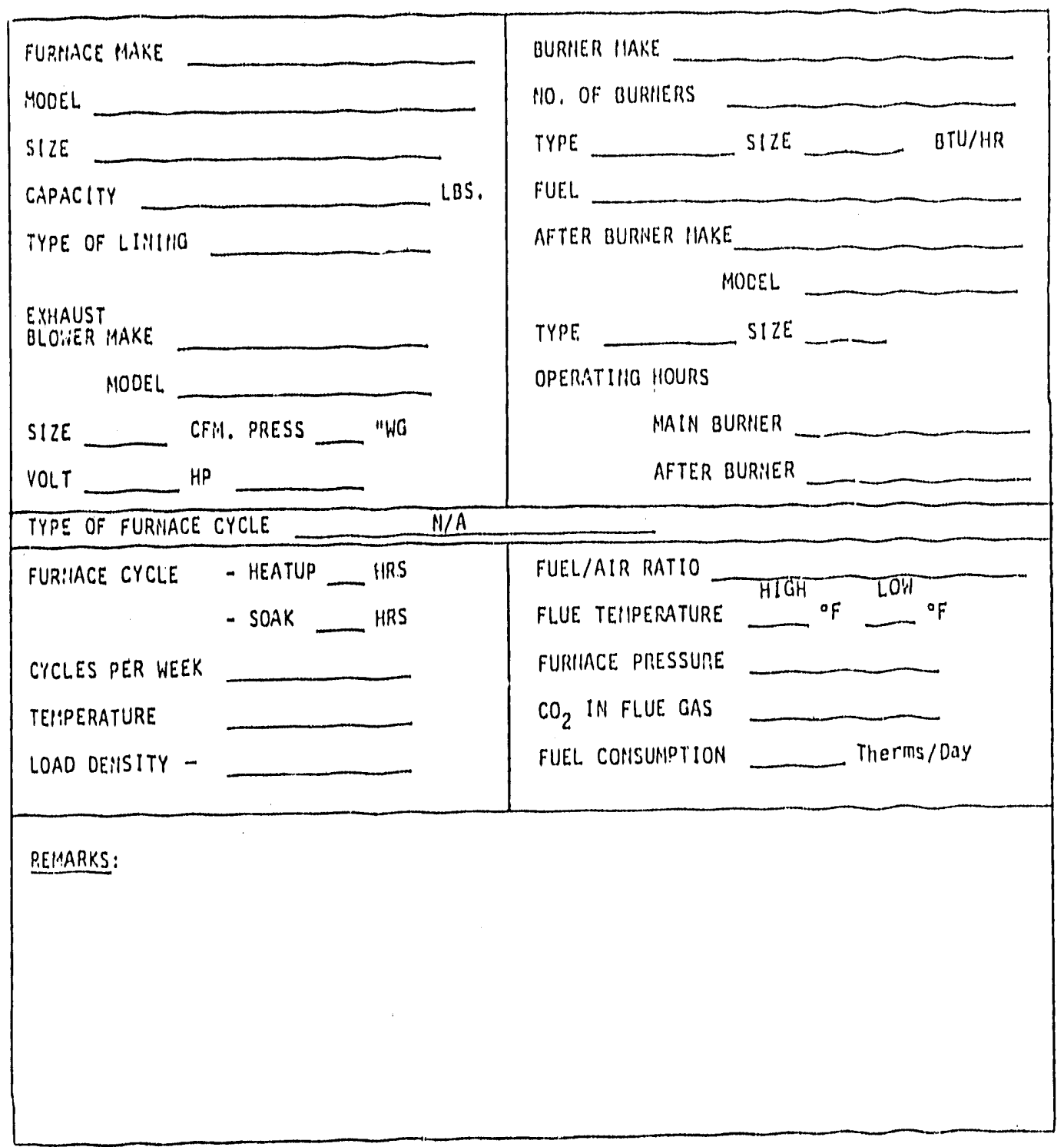

FORM $\quad 4-17$ 
OPERATIONAL DATA FACT SHEET

LADLE PREHEAT DATA

LADLE CAP TONS

HEAT CYCLES/DAY

LADLE. AREA INSIDE

SQ FT. LINING THICKNESS

COVERED

TYPE OF LINING

INSIDE TEMP

${ }^{\circ} F$ OUTER SHELL TEMP

AMBIENT TEMP ${ }^{0} \mathrm{~F}$

GAS USAGE/HR $\mathrm{CU} \mathrm{FT}, \quad \mathrm{CO}_{2}$ READING

COMBUSTION AIR CFM PRESSURE WG PREHEAT CYCLE TIME HRS FLUE TEMP ${ }^{O_{F}}$ REFRACTORY $K$ VALUE RS VALUE

BLOWER HP RECUPERATOR EFFCY

FUEL COST/THERM \$ ANNUAL USE

BTU $\times 10^{6}$ NUMBER OF UNITS IN USE

REMARKS:

FORM $\quad 4-18$ 


\section{OPERATIONAL DATA FACT SHEET \\ CUPOLA DATA}

CUPOLA DIA SHELL INS REFRACTORY THICKNESS

LINING INS WATER COOLING GPM

HEIGHT OF TUYERES ABOVE HEARTH INS

LAUNDER LENGTH WIDTH

METAL TO COKE RATIO BED COKE LBS

MELT RATE TPH COKE ADDITION/HR LBS

BLAST RATE CFM PRESSURE ONZ

NUMBER OF TUYERES DIAMETER IN NUMBER OF ROWS OF TUYERES SPACING IN

COOLING WATER USAGE GPM $\quad r_{1}-t_{2}$ ${ }^{0} \mathbf{F}$

FAN HP MISC. HP

HOT BLAST TEMP ${ }^{\circ} \mathrm{F}$ RECUPERATOR CAP BUT / HR AFTER BURNER RATING BTU/HR OXYGEN ENRICHMENT PERCENT ADDITION $q$ MELTING PERIOD; BLAST ON BLAST OFF COKE BREEZE ADDITION, PERCENT OF COKE 8 ANTHRACITE ADDITION, PERCENT OF COKE

\section{REMARKS :}


OPERATIONAL DATA FACT SHEET

HEAT TREAT FURNACES (ELECTRIC)

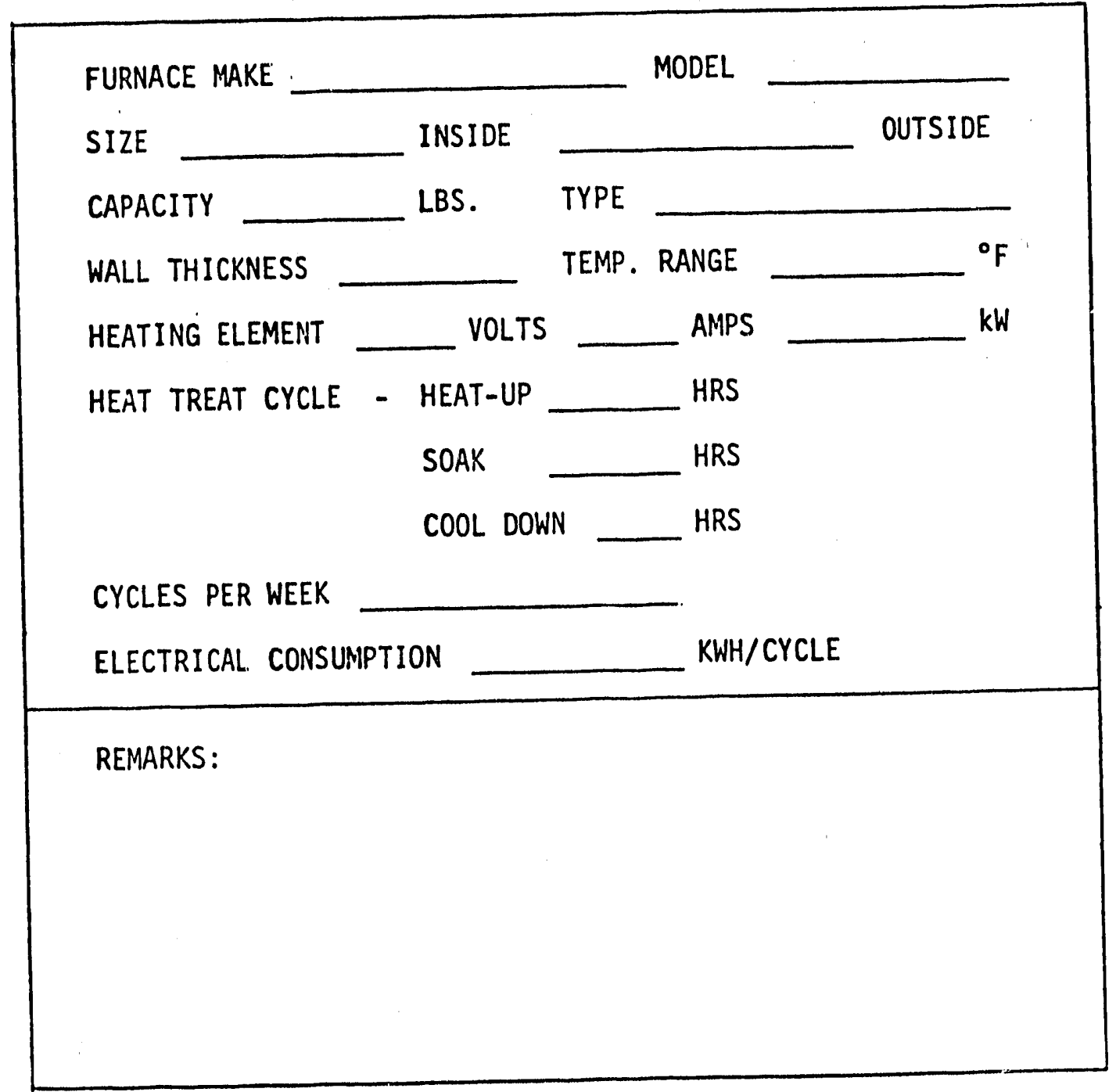


OPERATIONAL DATA FACT SHEET

GAS-FIRED SCRAP PREHEAT

METAL TYPE

DENSITY

LBS/CU.FT.

PREHEAT TEMPERATURE

${ }^{\circ} \mathrm{F} . \quad$ CYCLE

HRS

MELTING CAPACITY

TONS/DAY. MELT RATE

TONS/HR

FUEL AVAILABLE FOR PREHEAT

COST/THERM

CHARGE SIZE/WEIGHT PER BATCH LBS

PREHEAT BURNER RATING BTU/HR

$\mathrm{CO}_{2}$ FLUE GAS READING

TEMPERATURE

${ }^{\circ} \mathrm{F}$

COMBUSTION AIR CFM

PRESSURE

WG

AMBIENT TEMPERATURE

TIME OF DAY USED

SHIFTS PER DAY

DAYS/YEAR

REMARKS:

FORM 4-21 
Mary energy savings opportunities exist in all foundries that can be instituted immediately without requiring large capital equipment investments. The checklist that follows presents these no cost/low cost energy savings ideas together with suggestion modifications and changes that will require medium to major capital investments:

Infiltration-Infiltration of cold air into the plant through cracks, openings, gaps around doors and windows, etc., increases the building's heat load and may be responsible for 20 to 25 percent of the yearly space-heating energy consumption. This waste can be eliminated, and an additional saving in heat ing realized, by taking the following steps:

1. Replace broken or cracked window panes.

2. Caulk cracks around wincow and door frames.

3. Weatherstrip windows and doors.

4. Close windows while the building is being heated.

5. Check sealing gaskets and latches for all operable windows to see that they are working properly.

6. Close ali rolling-type coors when they are not being used.

7. Eliminate unnecessary windows and skylights.

Heating, Ventilating, and Air-Conditioning (HVAC) Systems--HVAC systems have a significant impact on the plant's total energy consumption. These changes in operational routine can cut HVAC energy use 5 to 15 percent:

1. Establish mininum temperature leveis for the heating season and maximum levels for the cooling season. Establisting these levels requires consideration of occupied and unoccupied periods.

2. Repair or replace all damaged or defective thermostats or control equipment; calibrate as necessary.

3. Mount thermostats on inside walls and columns only.

4. Lock all thermostats to prevent unauthorized personnel from tainpering with then.

5. Eliminate the use of mechanical cooling when the plant is unoccupied. Turn off heat or maintain a $50 \mathrm{~F}$ minimum in unoccupied areas.

6. Inspect all outside air clampers to ensure that they establish an air-tight fit when closed.

7. Establish startup and shutoff times for HVAC systems.

8. Shut off or adjust HVAC systems during week ends and holidays.

9. Minimize outdoor air intake.

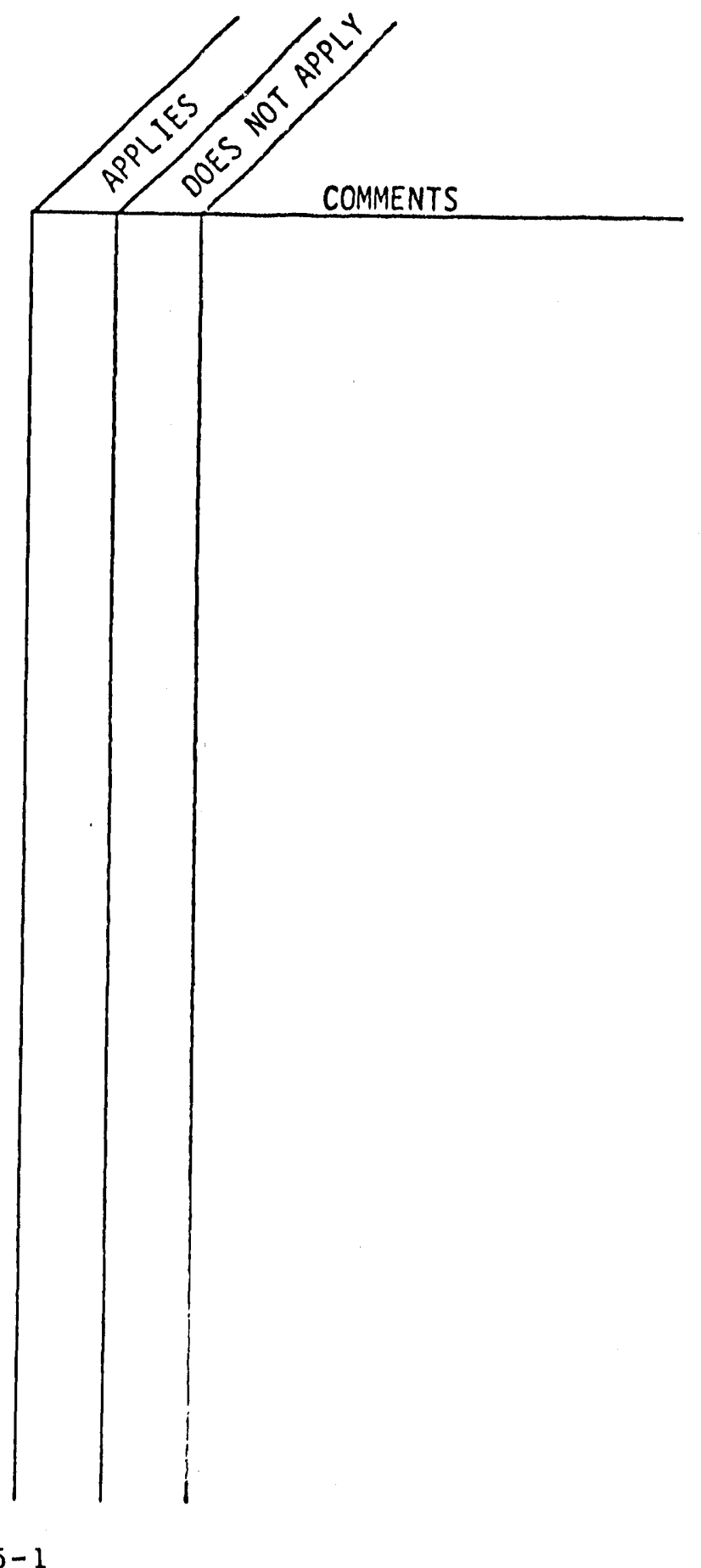


Maxeup-Air Units-- Whenever air must be heated, ineffictencies are probable. The following modifications to makeup-air units can help conserve energy:

1. Adjust burners for proper flame patterns.

-2. Clean burner nozzles periodically to remove mineral deposits and corrosion buildup.

3. Observe the fire when the un it shuts down. A fire that does not cut off immediately could indicate a faulty control valve. Repair or replace the control valve as necessary.

4. Keep all heat-exchanger surfaces clean.

5. Inspect casings for air leaks. Seal them as necessary.

6. Clean or replace a ir filters regularly.

7. Keep fan blades clean.

8. Inspect and lubricate motor bearing regularly.

9. Inspect fan inlets and discharge screens to keep them free of dirt and debris at all times.

Insulation--Transmission heat losses and gains through walls, glass, roof, floor, etc, can be controlled with adequate insulation. The savings depend on the loss reductions achieved. A 5 to 10 percent saving is possible.

Lighting--Lighting represents a major portion of electrical energy use. A reasonable effort should be made to use only the amount of lighting necessary for safety and efficiency. Taking the following steps could lower plant electrical energy consumption approximately 5 to 15 percent:

1. Use daylight for illumination when possible. Turn off lights when sufficient daylight is available.

2. Turn off lights at $n$ ight and in unoccupled areas during the day.

3. Install simple timers on light switches throughout the plant, including in offices.

4. Keep lighting equipment clean and in good working order.

5. Replace burned out or darkened lamps and clean all fixtures.

6. Increase the light-reflective quality of walls and ceilings with light colors. Such improvements may permit additional lighting reductions.

Boilers-- In any boiler operation, the main source of energy waste is inefficient combustion. A 10 to 25 percent energy saving is possible by reularly following these simple checks and guidelines:

1. Inspect boilers for scale deposits.

-2. Keep all heat-transfer surfaces as clean as possible to reduce temperature differences.

3. Follow the boller manufacturer's recomendations.

4. Follow the feedwater treatment and blowdown procedures recomended by the supplier. This measure will save fuel by minimizing scale formation.

5. Inspect door seals and other seal gaskets. Leaking gaskets waste fuel; doors may be deformed.

6. Check boiler stack temperature. If it is too high (more than 150 to $200 \mathrm{deg} F$ above steam temperature), clean the tubes and adjust the burner.

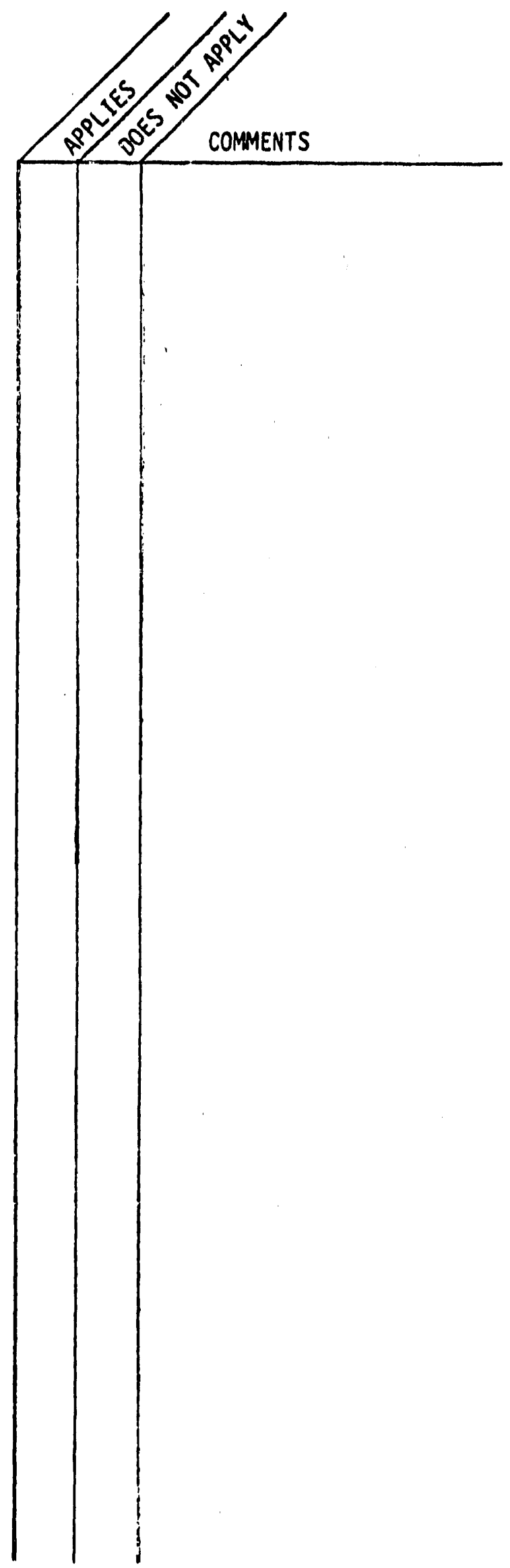


7. Adjust the burner so that the stacks are free of haze.

8. Collect and analyze flue gas samples regularly to determine if combustion is efficient.

9. Minimize the amount of excess air supplied for combustion.

10. Operate only one boiler unless it cannot sup. ply the load.

11. Prevent short-cycle firing.

Steam Lines and Traps--Whether small or large, the leaks in steam piping, fittings, valves, and traps add up and san waste large amounts of energy. A detalled survey of all such piping should be made weekly or monthly and the following steps should be taken:

1. Repair or replace defective or missing insulation.

2. Inspect steam traps and replace those that are worn, inoperat ive, or iniproperly sized.

3. Inspect pressure-reducing and regulating valves and their related equipment. Adjust, repair, or replace as necessary.

4. Check pressure gauges and thermometers for recording accuracy.

Fans, Pumps, and Motors--Proper maintenance of fans, pumps, and motors can significantly improve the ir operational efficiency. The following steps can save energy at a lmost no cost:

Fans:

1. Clean the blades.

-2. Inspect and lubricate bearings regularly.

-3. Inspect belts for proper tension.

-4. Keep inlet and discharge screens free of tirt and debris.

Pumps:

1. Check packings for wear. Bad packings waste water and erode the shaft.

2. Inspect bearings and belts regulariy. Motors:

1. Keep motors clean.

2. Prevent overvoltage and undervoltage.

-3. Eliminate excessive vibration.

-4. Correct loose connections, bad contacts, belts, pulleys, bearings, etc.

5. Check for overheating and provide adequate ventilation.

6. Prevent imbalance in power phase sources. This candition can cause inefficient motor operation.

Domestic Hot and Cold Water--Following these guidelines can maximize the efficiency of domestic water use:

1. Inspect the water supply system and repair leaks, especially faucet leaks.

2. Inspect insulation on storage tanks and piping. Repair as needed.

3. Turn off the pump when the building is unoccupied, if hot water is distributed by forced circulation.

4. Inspect and test hot-water controls. Regulate, repair, or replace as necessary.

5. Disconnec: all refrigerated water fountains, if acceptable to bufiding occupants. 


\section{Compressed Air Systems}

1. Instali either solenoid valves or remote operated valves on assembly line air matns to eliminate normal or accidental air leaks during non-operating hours.

2. Avoid utilizing expensive city water for once through compressor cooling system. Instead, investigate recycling cooling water through a cooling tower.

3. Investigate utilizing waste air compressor af tercooler cooling water $\left(95-115^{\circ} \mathrm{F}.\right)$ as boiler make up. This both saves the energy that would be required to heat city water from $55^{\circ}$ to $95^{\circ}$ and reduces the waste water discharged to city sewers with a resultant sewer charge reduction. As a rule of thumb, this will result in a 2 gallon fuel ofl saving per 1000 gallons of make up water.

4. Install solenoid valves on all machine air supply lines to limit air use to actual machine operating perlods.

5. If large quantities of low pressure compressed air are required, consider installing a separate low pressure compressor rather than reducing from the main plant supply.

6. Be sure the compressed air intake is in a cool location. Every $5^{\circ} \mathrm{F}$. drop in intake air temperature results in a $1 \%$ increase in compressed air volume for the same compressor hor sepower requirements.

7. Extra air receivers at points of high periodic air demand may permit operation without extra air compressor capacity.

8. Keep compressor values in good condition for maximum efficiency (worn valves can easily reduce compressor efficiency 50x). Many compressor manufacturers recommend removal and inspection every 6 months.

9. Match compressor pressure to actual system requirements. Operating a compressed air system at higher than requiered pressure results in higher compressor maintenance and reduced efficiency, as well as increased operating costs.' Most air tools are designed to operate with 90 PSI at the tool. Higher pressures result in increased maintenance and shorter tool 1 expectancy. Typically, a 10x increase $j$ "essure will reduce too life about $14 x$.

10. Size air hoses "or minimal pressure drop to air tools. For instance, a tool designed to operate on 90 PSI will operate on 80 PSI, but at a 15\% reduction in production.

11. Consider the installation of double acting water cooled piston compressors rather than rotary screw compressors if the compressor will be operating at partial load much of the time. A double acting water cooled piston compressor requires as itttle as 5-7\% of full load hor sepower when unloaded, while a rotary screw compressor can require as much as 60 . $75 \%$ of full load horsepower when unloaded.

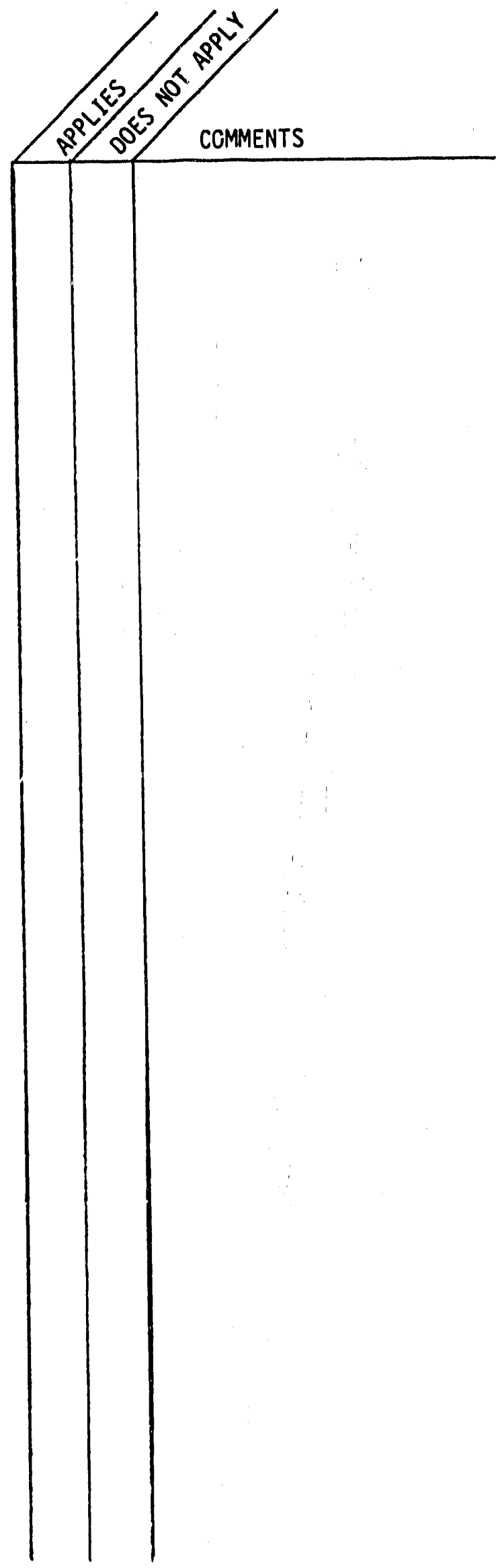


12. Locate and repair all piping leaks. Typically, many manufacturing plants lose about 10x of the ir compressed air through leaks, usually from loose pipe fittings, valve packing, shut off valves, worn out filters-regulators-lubricators, quick couplers, and unused air tools. A $1 / 16^{\text {" leak can waste } 6.5}$ $\mathrm{cfm}$, and in addition to wasting compressor horsepower, will cost $\$ 8.00$ per month. The hundreds of leaks in many industrial air systems can represent a tremendous energy waste.

13. Be careful to size compressor capacity fairly closely to load, since a compressor's effi. ciency is highest at full load.

14. Consider the installation of several smaller compressors rather than one large unit. Sequential operation will enable each compressor to operate at full load.

15. Prohibit all use of compressed air operated fans or compressed air hoses for personal cooling.

16. Remember that it requires about 1 horsepower to produce 5 CFM 100 PSI while a 1 horsepower vane type air motor requires about 25 CFM 90 PSI. Investigate replacing high usage air motors with electric motors where practical.

17. Consider using solenoid valves to cycle punch press blow off nozzles for only a short interval. Many blow off nozzles have a $1 / 8^{4}$ orifice and, if operated continuously, will consume about 25 CFM 8100 PSI (the equivalent of $5 \mathrm{HP}$ compressor).

18. Consider reducing the operating speed/pres sure on air operated paint pumps and paint agitators during off-shift hours. Depending on pigmentation and metallic content it may even be possible to stop all agitation or circulation of some enamels or lacquers during off hours.

19. In addition to poor partial load mechanical efficiency, induction type compressor motors have extremely poor power factors at reduced outputs. For instance, a $250 \mathrm{HP}$ induction motor has a .87 PF at full load and a .55 PF at $1 / 4$ load. Significant low load operation can drastically raise utility power factor charges.

20. For highest efficiency, be sure air tools are kept in good repair and are not excessively worn. For instance, a sand blast nozzle worn from $5 / 16^{\prime \prime}$ to a new diameter of $3 / 8^{\prime \prime}$ would consume an additional 65-70 CFM.

21. Minimize low load compressor operation. If air demand is less than 50\% of compressor capacity, consider converting smaller compressors from constant speed operation to start/stop operation.

22. Install timers on desiccant type cumpressed air dryers to match dryer. recharging cycles to actual system requirements.

23. Match compressor operation to building hours. A time switch can permit close control of compressor hours and permit shut down of high unloaded horsepower compressors during meal breaks or shift changes. 
Welding Operations

1. Investigate converting heating equipment fuel from acetylene, natural gas, or propane to methylacetylene propadiene, stabllized (MAPP). This gas may reusit in the improved performance, higher cutting speeds and reduced oxygen consumption.

2. If product design is applicable, consider utflizing seam welding (RSEW) instead of coated electrode metal arc welding (SMAW), metallic inert-gas welding (GMAW), or submerged arc welding (SAW). Since high frequency seam welding only heats the actual welding zone, distortion is minimized. The process is also less energy intensive than most other applicable welding processes.

3. Consider utilizing electronic precipitators to "scrub" welding exhaust fumes and thereby eliminate building exhaust with its attendant heat loss.

4. Install solenotd valves on welder or water cooled torch supply lines to limit cooling water flow to actual welder operating periods.

5. Consider the installation of smoke detectors to control welding exhaust fans.

6. Investigate inerta welding for uniform tubular or solid sections and simflar shapes. Inerta welding can of ten replace alternative welding methods with their related preparatory machining operation.

7. Investigate using bag type dust collectors/filters to reduce bullding exhaust.

8. If welding shop workload varies widely, investigate ordering any new transformer type welders with built-in power factor correcting capacitors.

9. If oxy-acetylene welding/cutting torches are frequently used throughout the day, consider installing weight actuated automatic torch valves. This should help insure that an unused torch is turned off when it is hung up.

10. Investigate the installation of automatic cutting torches, which nonmally operate at maximum speed, thus yielding maximum cutting for minimum gas consumption. Their cutting speed and accuracy can often replace more energy intensive alternative manufacturing methods.

11. Be sure gas welding equipment connections and hoses are tight. Leaks both waste expensive gas and are fire hazards.

12. Investigate using high frequency induction heating for brazing operations instead of hand-held torch or a furnace.

13. Consider operating automatic cutting torches on natural gas or propane instead of acetylene. Acetylene has a higher flame temperature than normally required for steel cutting.

14. Consider using hot air instead of direct gas flame soldering torches. Since hot air is supplied at lower temperatures, it conserves energy and improves product apperance, as well as reducing fire hazards.

15. Replace cont inuous pilot lights for gas welding torches with conventional flint lighters. 
16. Be careful to avold over-welding, efther during design or manufacture.

17. Use flame gouging instead of chipping hamers to remove tack welds, full welds, defects, blow holes, or sand inclusions.

18. Consider using flame deseaming or scarfing instead of chipping hamers to remove cracks, seams, scabs, and crowsfeet. Hot scarfing can clean up forgings without the cooling and reheating required by chipping.

19. In general, transformer type arc welders are more energy effictent than motor-generator welders. At full rated load, transformer type welders will consume slightly less power than a comparable motor-generator welder.' At partial or no load, however, motor generator efficiency and power factor drop appreciably.

20. Motor generator welders are valuable where ripple-free $D C$ is required from single phase power. A transformer-rectiffer welder cannot normally deliver weil filtered $D C$ from single phase power.

21. Investigate "stack cutting" with automatic cutting torches. In many cases, a thicker cut uses proportionately less oxygen per piece than a thinner cut. Cutting accuracy is a maximum below 2 " total thickness and gradually deteriorates unt il the normal maximum cutting thickness of $6^{\prime \prime}$ is attained.

22. Shut down transformer type and motor-generator arc welders when not in use and during breaks and lunch. Savings will be minimal with transformer type welders but will become increasingly significant when motor-generator welders are stopped.

23. Be sure unused automatic torchies are turned off when not in use. Avoid excessive idle time.

Process and Manufacturing Operations

1. Evaluate all machine tool purchases carefully for operating efficiency. In some cases, an alternative manufacturing method may result in lower energy usage per piece.

2. Consider installing electrostatic precipitators to minimize dust or particle exhaust. such as from welding operations.

3. Investigate installing smoke detectors to operate exhaust fans.

4. Inter lock process ventilation equipment with the equipment it serves.

5. Replace simplex or duplex steam pumps with motor driven pumps where feasible.

6. Install timers on punch presses, press brakes, and hydraulic pressses to shut down equipment if left idling for more than 10-12 minutes.

7. Install solenoid valves on all machine air supply lines to limit air use to machine operating periods.

8. Investigate using mechanical methods, such as a cam or solenoid to eject punch press parts instead of using compressed air.

9. Install either automatic doors or insulated flaps on conveyor type heat treating ovens to reduce heat loss.

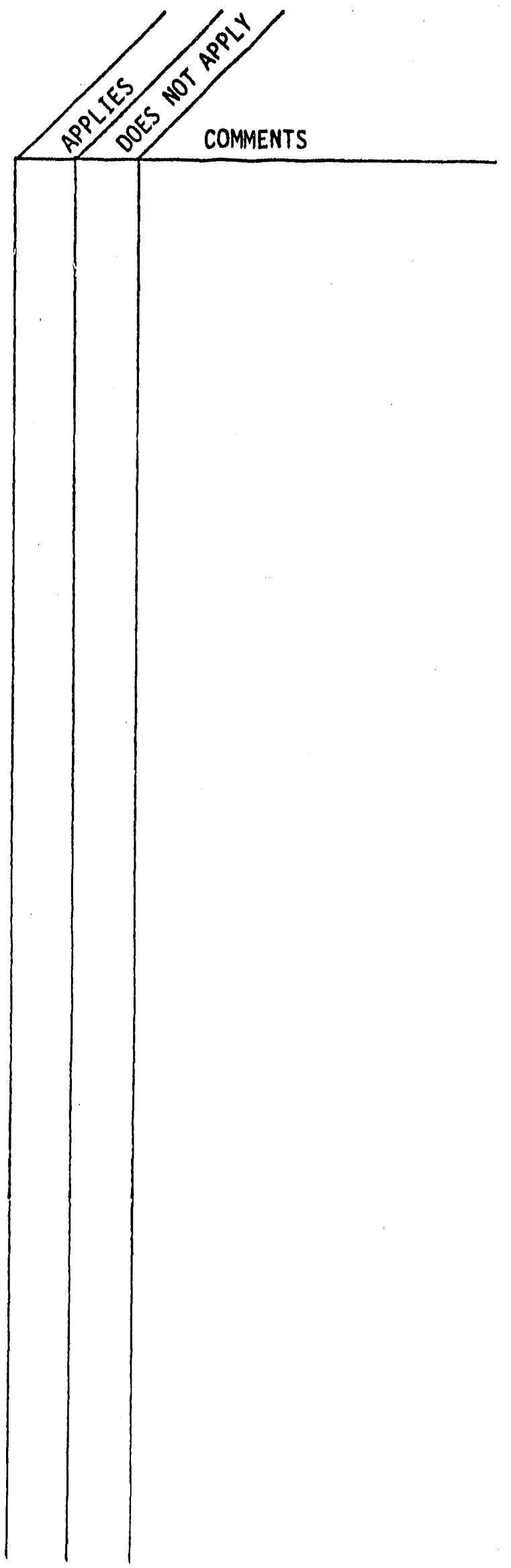


10. Install solenold values on all water cooled equipment water lines to min imize water leakage.

11. Redesign processes to eliminate process exhaust ventilation.

12. Investigate the installation of reflecting shielding or thermal barriers around heat treating equipment to minimize cooling load on adjacent areas, particularly in metallurgical laboratories.

13. All water pumping equipment will have to operate at less than full design flow, consider the installation of variable speed pumps to minimize reduced flow power consumption.

14. Avoid severely oversizing production equipment. An oversized tool is normally heavier and requires more power than a smaller, correctly sized tool.

15. Operate air tools on correct pressure. Most air tools are designed to operate on 90 PSI. Tool operation on lower pressures reduces output, whlle only a 10 pound pressure increase results in a $14 \%$ tool life expectancy reduction.

16. Meter unusual gas or process chemical requirements. "Billing" a department for actual consumption can of ten result in phenomonal consumption reductions.

17. Modify product test or analysis procedures to avoid high energy consumption tests. For instance, minimize test time on engine operated equipment.

18. Investigate the feasibllity of operating production machinery at 100\% load for one shift rather than at partial load for two shifts. For instance, careful scheduling of vapor degreaser opeation may permit full load operation for fewer hours.

19. Attempt to reduce machine idle time as much as feasible to maintain high power factors.

20. Assign specific plant personnel to be sure all production equioment is shut down after shift and during breaks and lunch.

21. Operate melt. furnace exhausts only during furnace charging or fluxing if feasible.

22. Shut down process ventilation, bullding exhaust, and dust collection during breaks and lunch.

23. If heat treating ovens are not required for imediate use, energy can be saved by reverting to a reduced temperature condition. Investigate constructing a $\mathrm{cool}$ down/reheat time chart for varfous furnace temperature. This will enable operating personnel to easily reduce furnace temperatures and still be able to have the furnace up to heat by the desired time.

24. Consider operating heat treating ovens 24 hours/day to make maximum usage of energy.

25. Use fixed cycle times for heat treating/annealing operations. Many actual oven times are far longer than actually required, with a resulting energy waste.

26. Operate chip conveyors only when needed, not continuously.

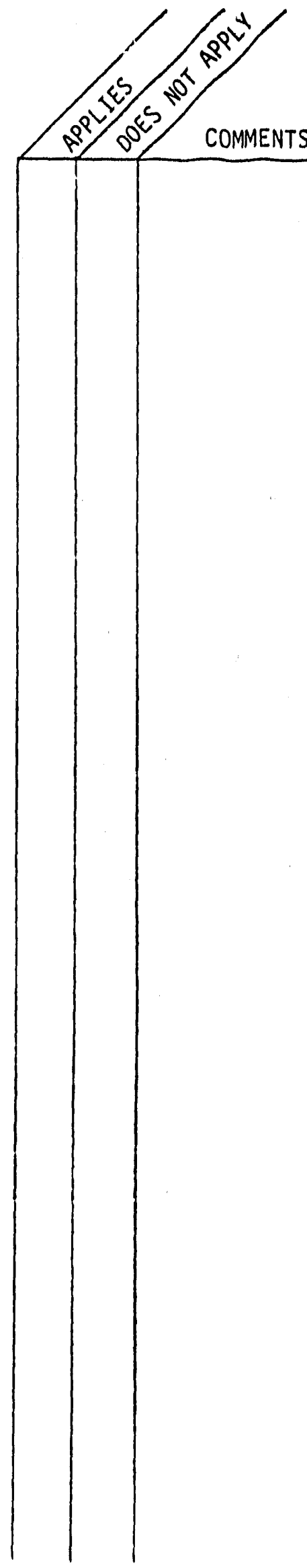


27. Avold partial heat treating furnace loads.

28. Shift or combine operations for both reduced bullding hours and improved machine ut lilization.

29. Minimize leaks and overflow from heated process tanks.

Mater fal Handling and Transportat ton Systems

1. Instaif "bump throughi" doors in fork lift areas to reduce open door time.

2. Install a flexible covering, such as rubber or canvas strip, over scrap conveyor openings in butlding walls.

3. Shrouds should be used in all dock doors when possible. Investigate using atr curtain fans If shrouds are not avallable.

4. Investigate installation of "air pallets". In some cases, they can offer energy reductions compared to lift trucks, particularly where an oddly shaped work plece must be moved short distances at slow speeds.

5. Be sure fork lift air cleaners are clean. Some high dust locations may require centrifugal pre-cleaners to prolong filter element life.

6. Be sure to purchase fork lift fuel that meets the manufacturers standards. Barga in fuel can actually reduce operating efficiency.

7. In a large operation, consider the installation of two-way radto equipment on material handling equipment to reduce the number of empty return trips. Try to schedule several moves for fork lifts in an area to maximize productivity.

8. Consider purchasing diesel fueled fork lifts. Their reduced fuel consumption and lower maintenance should result in substantial savings over gasoline or propane lifts.

9. Investigate replacing internal combustion fork lifts with electric fork lifts. In many cases, operating costs (and energy consumption) will be lower. In some cases matntenace costs may drop up to $30 \%$. Electric trucks al so have lower downt ime, are non-polluting, and are quiteter.

10. Consider installing electrical hoists rather than air operated hoists since "l horsepower" air ho ist requires about 5 compressor horsepower, while a "1 horsepower" electric hoist requires only 1 horsepower.

11. Replace old, out-moded (and inefficient) motor-generator electric fork lift battery chargers with new, solld state, power factor corrected high efficiency battery chargers.

12. Avoid pushing loads. Though this only wastes fuel and wears clutches with an engine operated truck, it can severely damage a battery operated lift truck's drive motor.

13. Install overspeed governors on all internal combustion material handling equipment, particularly fork lifts, to eliminate empolyee hot rodding.

14. Investigate fork ifft records or contact manuf acturers to discover the best fork ifft fuel consumption: Log all machine fuel to determine operator errors or machine deterioration. 
15. Be careful not to overfill fork lift fuel tanks. Spilled gasoline or diesel fuel or vented LPG is both wasteful and hazardous.

16. If a light load has to be moved a short distance, use a hand truck rather than a fork lift. Be sure fork lifts are used for material handling, not personal transportation.

17. Be sure pneumatic fork lift tires are properly inflated. Under inflation both damages tires and wastes fuel.

18. Avoid using a far larger fork lift then required. For initance, use a 2000 pound ifft to maneuver oil barrels rather than a 6000 pound lift.

19. Avoid excessive fork ifft idling. Start a lift only when there is work to be done - and stop it as soon as it is completed.

20. Avoid making a hatit of using a drastically oversized crane for a drastically undersized load. If a machine frequently requires a crane to load small work pieces, consider installing a small jib crane with an electric hoist. This both frees up the main crane for heavier jobs and saves energy.

21. Install automatic timers to shut down crane motor generators if no crane moves are made within ten minutes.

Paint Line Operations

1. Consider use of airless spray instead of air spray paint application. While it requires about 9.5 HP to atomize $1 \mathrm{GPM}$ using air spray, it only requires about $1.3 \mathrm{HP}$ to atomize I GPM using airless spray. Airless spray is particularly suited to large, heavy work pleces that must be painted with one coat, in place, such as heavy construction equipment, barges, structural steel, or railroad cars.

2. Since natural gas is a decreasing resource, investigate the applicability of ultraviolet cured metal finishes to your product. Frequently, product redesign may enable the use of ultra-violet post coating or may permit using pre-coated coil stock. In many cases, coll coating uses only about $20 \%$ of the energy required for post painting.

3. Consider installation of direct fired paint ovens instead of indirect fired. The heat transfer coefficient for dirct fired is about 97\% versus 60\% for indirect fired, with comparable differences in fuel consumption.

4. Investigate conversion to water base painting materials. Water base usually cuts energy consumption by reducing spray booth air flow, oven exhaust, air makeup requirements, and oven times. In some cases, finishing lines have reudced total natural gas consumption up to $45 \%$.

5. Research is currently being done to develop low temperature cure and air dry waterbase coatings. Current future forecasts of ten predict water base may account for up to $60 x$ of the industrial finishing market by 1985 .

6. Consider utilizing gas fired washer combus. tion products to provide heat for dry off oven. This would be paricularly applicable to direct fired washers. 
7. If your product configuration is applicable, consider converting to a high intensity infra-red curing which uses as little as 10\% of the energy required for a comparable gas fired oven.

8. Investigate converting paint ovens to the "Raw Oven Exhaust Recycle Process". This system returns part of the oven exhaust back to the oven after passing through an incinerator.

9. Investigate conversion to airless paint drying from conventional oven baking. This system holds oven oxygen content to as low as $1 \%$, with resulting reductions in oven exhaust and gas requirements.

10. Reduce spray booth/makeup air temperature to $65^{\circ}-68^{\circ}$

11. Investigate installing electric ovens instead of gas or oil fired. Higher operating costs are somewhat reduced by better temper. ature control, constant one-fuel operation, and more readily controlable oven atmosphere.

12. Consider insulating the entire paint line parts washer to reduce heat loss. Some plant operators estimate they have achleved up to 20\% fuel reduction in metal pretreatment operations after insulating parts washers.

13. If insulat ing the entire washer is not feasible, investigate insulating the heated por$t$ ion of the washer.

14. Consider additional paint oven wall insulation. Doubling the present thickness (usually only 2") will cut wall losses in half. Since most paint oven heat is lost through oven roofs, this portion in particular should be well insulated.

15. Consider utilizing ambient temperature solvent flash off if possible. In many casses, a slightly longer or slower conveyor may be all that is required.

16. Considerable heat is lost through oven "air seals", which are generally ineffective. Consider installation of bottom entry/exit oven, which better retain heated air within the oven.

17. Consider installations of oil fired paint ovens instead of gas fired. New oven technology can minimize paint discoloration and soot problems if a light, low sulfur (1x). oil is used.

18. Consider heat recovery equipment, such as "heat pipes", in spray booth and bake oven stacks. If heat recovery equipment is used, a regular maintenance program is required to minimize heat losses caused by paint residue build up.

19. Consider switching to low or ambient temperature parts washer cleaners and phosphating compounds. For instance, iron phosphates are now being successfully used at $100-120^{\circ} \mathrm{F}$. in some applications.

20. Investigate staging spray booth air flow. If painters work only in the first section. with automatic spray equipment in the remaining zones, the booth air can flow into the first zone, and be exhausted to the other zones. In many cases, solvent concentration in the final zone would stlll be below the $25 \%$ LFL limit. 
21. Replacing manual spray with automatic paint spraying machinery may permit a reduction in spray booth air velocity with a resultant make up air reduction. Material flamability and toxicity must be investigated to determine if any reductions are feastble. This normally requires approval from insurance inspectors, fire inspectors, 0.S.H.A., and any other applicable agencies.

22. Investigate using process steam condensate as heat source for paint line parts washer tanks.

23. Use a fixed or ifice rather than an adjustable valve to meter water into process or paint line constant overflow tanks for minimum flow.

24. Check booth velocity carefully to avoid over exhausting. Consider using electrostatic spray since this usually pernits a reduction of booth velocity of about $40 \%$.

25. Investigate inter locking paint line conveyors with parts washers and bake ovens.

26. Investigate the feasibility of operating fume incinerators at reduced temperatures.

27. If paint line or process exhausts include extremly high solvent concentrations, investigate recovering and re-refining these otherwise wasted solvents. In some cases, solvents have been reclaimed at an energy cost $1 / 5-1 / 6$ the price of new solvent.

28. Be sure plant is not occasionally under negative pressure. Negative pressure can starve gas burners resulting in a fuel rich flame with excess CO. Negative pressure also results in increased air infusion through walls and windows, with resulting cold drafts and worker complaints.

29. Be sure all stages in a process are really necessary. In some applications, washer stages may be eliminated or partially shut down, as may dry off ovens.

30. If batch ovens are used, maximize loading and opt imize working hours for highest energy ef ficiency. Similarly, minimize warm up time as much as possible.

31. Because solvents are increasingly scarce and expensive, consider filtering, distilling, or otherwise recycling solvent.

32. It may be possible to improve paint oven heat transfer by increasing circulating air velocities or volume and by utilizing heating system radiant energy. Improved heat transfer may permit increased travel speeds with resulting increases in production with little or no increase in fuel reuqirements.

33. Sequentially shut down ovens at end of shift or production run.

34. Attempt to schedule all paint line operations for one shift if feasible.

35. Be sure all gas immersion tubes used for liquid heating are clean (both interior and exterior) for best heat transfer.

36. Be sure all air filters are kept clean.

37. Change paint line conveyor speed and hook configuation as required with product changes to maximize productivity and minimize oven idle time.

38. Reduce conveyor speed when parts are not flowing through wash or bake ovens.

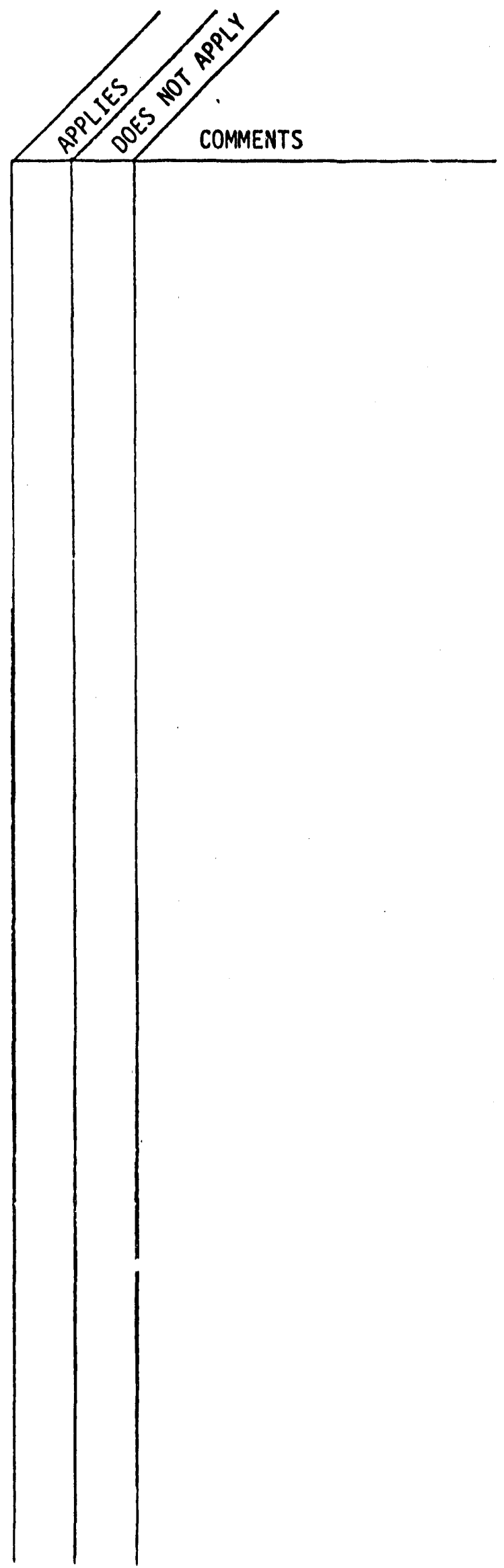


NOTE: DATA AND CALCULATIONS ARE FOR A HYPOTHETICAL FOUNDRY "A".

\section{GENERAL DESCRIPTION}

The foundry produces fobbing type Gray and Ductile Iron castings, averaging 17 pounds each. Cope and drag green sand molding systers and a no-bake line operates one shift per day.

\section{Facllitieg}

$\begin{array}{lll}\text { Building Area } & - & 90,000 \text { Square Feat } \\ \text { Manning Total } & - & 139 \\ \text { Average Shipments } & - & 1,530 \text { tons/Year } \\ \text { Average Sales Volume } & - & \$ 5.0 \mathrm{Million} \\ \text { Average Foundry Yield } & - & 39.3 \%\end{array}$

Melting Furnaces

Capacities: 2 Cupolas, 42" diameter water cooled w/apprx. 18

$O_{2}$ enrichment melt at 4.5 tons/hr

1 Coreless Induction furnace, $340 \mathrm{KW}$

3,000 pound capacity (600* charge)

Melting: 8 hours per day - 5 days per week

48 weeks per year

\section{Equipment}

Molding comprises 4 squeezer machines, 3 cope and drag units and a no-bake mixer, 350 per minute capacity. Sand plant mixing capacity is 3,000 pound batch muller with 100 ton storage and distribution system. Core sand preparation is in 75 pound capacity batch mixers serving 5 Isocure machines. Two shell core machines are avallable. The cleaning department provides for cut-off by abragive and gas torch methods. Heat treat furnaces operate on 21-hour and 18-hour cycles. Air compressors in three sizes operate up to 20 hours per day. No propane or fuel oll is used in the process except trucks. 
TABLE 6-I

ELECTRICAL POWER USAGE*

\begin{tabular}{|c|c|c|c|c|c|c|c|c|}
\hline BILLING PERIOD & ENERGY KWH & $\begin{array}{l}\text { BILLING } \\
\text { DEMAND }\end{array}$ & $\begin{array}{l}\text { POWER } \\
\text { FACTOR }\end{array}$ & $\begin{array}{l}\text { ENERGY } \\
\text { CHARGE }\end{array}$ & $\begin{array}{c}\text { FUEL } \\
\text { ADJUSTMENT* } \\
\text { CHARGE }\end{array}$ & $\begin{array}{l}\text { DEMAND } \\
\text { CHARGE }\end{array}$ & $\begin{array}{l}\text { GROSS } \\
\text { BILL }\end{array}$ & NET BILL \\
\hline JANUARY & 74,560 & N/A & $N / A$ & $N / A$ & $N / A$ & $N / A$ & $N / A$ & $3,833.60$ \\
\hline FEBRUARY & 78,720 & & & & & & & $3,835,00$ \\
\hline MARCH & 19,520 & & & & & & & $1,136,00$ \\
\hline APRIL & 62,080 & & & & & & & $3,025.00$ \\
\hline MAY & 58,880 & & & & & & & $2,892.00$ \\
\hline JUNE & 38,400 & & & & & & & $1,891.00$ \\
\hline JULY & 22,720 & & & & & & & $1,202.00$ \\
\hline AUGUST & 35,840 & & & & & & & $1,765.00$ \\
\hline SEPTEMBER & 23,680 & & & & & & & 1.219 .00 \\
\hline OCTOBER & 26,560 & & & & & & & $1,365, n 0$ \\
\hline NOVEMBER & 22,080 & & & & & & & $1,246,00$ \\
\hline DECEMBER & 49,920 & & & & & & & $2,590.00$ \\
\hline TOTALS & 512,960 & 1 & $r$ & T & t & 1 & 1 & $25,999.00$ \\
\hline
\end{tabular}

* general plant electric power usage.

AVERAGE POWER COSTS $=\frac{25,999}{512,960}=\$ 0.051 / \mathrm{KWH}$ 
TABLE 6-I

ELECTRICAL POWER USAGE*

\begin{tabular}{|c|c|c|c|c|c|c|c|c|}
\hline BILLIIIG PERIOD & ENERGY XWH & $\begin{array}{l}\text { BILLING } \\
\text { DENAND }\end{array}$ & $\begin{array}{c}\text { POWER } \\
\text { FACTOR }\end{array}$ & $\begin{array}{l}\text { ENERGY } \\
\text { CHARGE }\end{array}$ & $\begin{array}{c}\text { FUEL } \\
\text { ADJUSTMENT } \\
\text { CHARGE }\end{array}$ & $\begin{array}{l}\text { DEMAND } \\
\text { CHARGE }\end{array}$ & $\begin{array}{l}\text { GROSS } \\
\text { BILL }\end{array}$ & NET BILL \\
\hline JMilUARY & 179,400 & $\mathrm{~N} / \mathrm{A}$ & $N / A$ & $N / A$ & $N / A$ & $N / A$ & $N / A$ & $7,531.00$ \\
\hline FEBRUARY & 178,200 & & & & & & & $7,045.00$ \\
\hline MARCH & 90,600 & & & & & & & $4,135.00$ \\
\hline APRIL & 133,200 & & & & & & & $5,509,00$ \\
\hline MAY & 176,100 & & & & & & & $6,889.00$ \\
\hline JUNE & $173, i 00$ & & & & & & & $6,893.00$ \\
\hline JULY & 119,100 & & & & & & & $5,125.00$ \\
\hline AUGUST & 167,400 & & & & & & & $6,658.00$ \\
\hline SEPTEMBER & 150,900 & & & & & & & $6,133.00$ \\
\hline OCTOBER & 153,300 & & & & & & & $6,432.00$ \\
\hline NOVEMBER & 148,200 & & & & & & & $6,446.00$ \\
\hline OECEMBER & 132,900 & & & & & & & $5,914.00$ \\
\hline TOTALS & $1,803,000$ & $\checkmark$ & $\downarrow$ & t & $\uparrow$ & 1 & 1 & $74,710.00$ \\
\hline
\end{tabular}

* helt furilace electrical poler usage.

AVEPAGE POHER COST $=\frac{74,710}{1,803,000}=\$ 0.041 / \mathrm{KWH}$

COST SUIMIARY (PLANT \& MELT FURNACE)

\begin{tabular}{|c|c|c|}
\hline SERVICE & XWH & COST \\
\hline FURMACE & $1,803,000$ & $74,710.00$ \\
\hline GENERAL PLANT & 512,960 & $25,999.00$ \\
\hline & & \\
\hline TOTALS & $2,315,960$ & $100,709.00$ \\
\hline
\end{tabular}


TABLE 6-II

ANNUAL GAS CONSUMPTION

\begin{tabular}{|l|c|c|c|}
\hline \multicolumn{1}{|c|}{ PERIOD } & THERMS & BTU $\times 10^{6}$ & COST \\
\hline JANUARY & 32,288 & $3,228.8$ & $\$ 8,609.00$ \\
\hline FEBRUARY & 31,672 & $3,167.2$ & $8,445.00$ \\
\hline MARCH & 12,389 & $1,238.9$ & $3,304.00$ \\
\hline APRIL & 27,027 & $2,702.7$ & $7,206.00$ \\
\hline MAYY & 24,784 & $2,478.4$ & $6,608.00$ \\
\hline JUNE & 25,081 & $2,508.1$ & $7,175.00$ \\
\hline JULY & 17,232 & $1,723.2$ & $5,106.00$ \\
\hline AUGUST & 22,930 & $2,293.0$ & $6,793.00$ \\
\hline SEPTEMBER & 16,508 & $1,650.8$ & $4,891.00$ \\
\hline OCTOBER & 21,890 & $2,189.0$ & $6,805.00$ \\
\hline NOVEMBER & 18,617 & $1,861.7$ & $6,359.00$ \\
\hline DECEMBER & 20,306 & $2,030.6$ & $7,049.00$ \\
\hline & 270,724 & $27,072.4$ & $\$ 78,350.00$ \\
\hline TOTALS & & & \\
\hline
\end{tabular}

HEAT CONTENT OF GAS $=1,000$ BTU/CU FT (FROM BILL)

100,000 BTU $=1$ THERM

COST OF GAS $=\frac{78,350}{270,724}=\$ 0.289$ PER THERM 
TABLE 6-III

ANNUAL COKE CONSUMPTION

\begin{tabular}{|l|c|c|c|}
\hline \multicolumn{1}{|c|}{ PERIOD } & TONS & $\begin{array}{c}\text { BTU } \times 10^{6} \\
(012,500 \text { BTU/LB })\end{array}$ & COST \\
\hline JULY & 13 & 325 & $\$ 2,264.00$ \\
\hline AUGUST & 61.1 & $1,527.5$ & $10,801.00$ \\
\hline SEPTEMBER & 64.4 & 1,610 & $10,888.00$ \\
\hline OCTOBER & 134.1 & $3,352.5$ & $23,772.00$ \\
\hline NOVEMBER & 95 & 2,375 & $17,001.00$ \\
\hline DECEMBER & 177.8 & 4,445 & $30,656.00$ \\
\hline JANUARY & 169.4 & 4,235 & $31,367.00$ \\
\hline FEBRUARY & 105.4 & 2,635 & $19,429.00$ \\
\hline MARCH & 56.1 & $1,402.5$ & $10,801.00$ \\
\hline APRIL & 141 & 3,525 & $56,551.00$ \\
\hline MAY & 143.6 & 3,590 & $27,595.00$ \\
\hline JUNE & 122.74 & $3,068.5$ & $23,762.00$ \\
\hline & $1,283.64$ & 32,091 & $\$ 264,887.00$ \\
\hline
\end{tabular}

AVERAGE COST PER TON $=\frac{264,887}{1,283.64}=\$ 206.35$ 
TABLE 6-IV

DESCRIPTION AND POWER USAGE OF ELECTRICAL EQUIPMENT

\begin{tabular}{|c|c|c|c|c|c|c|c|}
\hline EQUIPMENT & TYPE & CAPACITY & $\begin{array}{r}\text { OPERA } \\
\text { HRSTJOAY }\end{array}$ & $\frac{\text { ATION }}{\text { OAYSTMO }}$ & H.P. & KWH & SERVICE \\
\hline \multicolumn{8}{|l|}{ MOLDING \#I DEPARTMENT } \\
\hline CONVEYOR & DELIVERY & & & & 5 & & \\
\hline CONVEYOR & GOOOMAN & & & & 10 & & \\
\hline SHAKEOUT & & & & & 10 & & \\
\hline CASTING CONVEYOR & & & & & 7.5 & & \\
\hline INCLINED CONVEYOR & & & & & 5 & & \\
\hline INCLINED CONVEYOR & & & & & 5 & & \\
\hline HOPPER CONVEYOR & & & & & 5 & & \\
\hline DUST COLLECTOR & & & & & 25 & & \\
\hline SPILLAGE CONVEYOR & & & & & 5 & & \\
\hline SAND MILL & & & & & 15 & & \\
\hline SAND IIILL & & & & & 50 & & \\
\hline BUCKET CONVEYOR & & & & & 7.5 & & \\
\hline MISCELLANEOUS & & & & & 18 & & \\
\hline SUBTOTAL & & & & & 168 & & \\
\hline MOLDING \#2 & & & & & & & \\
\hline CRAIIES & & & & & 50 & & \\
\hline PRE IIIX & & & & & 8.5 & & \\
\hline SHAKEOUT & & & & & 20 & & \\
\hline MISCELLANEOUS & & & & & 5 & & \\
\hline SUBTOTAL. & & & & & 83.5 & & \\
\hline
\end{tabular}


TABLE 6-IV (CONTINUED)

\begin{tabular}{|c|c|c|c|c|c|c|c|}
\hline EQUIPMENT & TYPE & CAPACITY & $\begin{array}{r}\text { OPERAT } \\
\text { TRSTOAAY }\end{array}$ & $\frac{\text { ATION }}{\text { TOAYS/MO }}$ & H.P. & XWH & SERVICE \\
\hline CORE ROONI & & & & & & & \\
\hline MYERS HOIST & ROBBINS & & & & 10 & & \\
\hline MIXERS & & & & & 11 & & \\
\hline DELIVERY CONVEYOR & & & & & 9 & & \\
\hline SAND MIXER & & & & & 5 & & \\
\hline HOIST & SHEPHERD NILES & & & & 5 & & \\
\hline MISCELLANEOUS & & & & & 11 & & \\
\hline .SUBTOTAL. & & & & & 51 & & \\
\hline CLEANING DEPARTMENT & & & & & & & \\
\hline GR!IIDERS & & & & & 50 & & \\
\hline TUMBLAST & & & & & 25 & & \\
\hline SWING GRINDER & & & & & 50 & & \\
\hline OVEN \#1 & & & & & 10 & & \\
\hline CUTOFF SAN & & & & & 25 & & \\
\hline DUST COLLECTOR & & & & & 15 & & \\
\hline CRANES & & & & & 44 & & \\
\hline CASTING BURINER & & & & & 5 & & \\
\hline CASTING FAN & & & & & 10 & & \\
\hline NIISCELLANEOUS & & & & & 15 & & \\
\hline SUBTOTAL & & & & & 249 & & \\
\hline
\end{tabular}


TABLE 6-IV (CONTINUED)

\begin{tabular}{|c|c|c|c|c|c|c|}
\hline EQUIPMENT & TYPE & CAPACITY & \begin{tabular}{|c|} 
OPERATION \\
TRSTOAY DAYSTMO \\
\end{tabular} & H.P. & $\mathrm{KW}$ & SERVICE \\
\hline \multicolumn{7}{|l|}{ PATTERN SHOP } \\
\hline TABLE SAM $\|$ & & & & 7.5 & & \\
\hline BAND SAW & & & & 5 & & \\
\hline BAND SAW & & & & 5 & & \\
\hline MISCELLANEOUS & & & & 6 & & \\
\hline SUBTOTAL & & & & 23.5 & & \\
\hline \multicolumn{7}{|l|}{ MELTING DEPARTMENT } \\
\hline CUPOLA BLOWER & & & & 30 & & \\
\hline SHOG BLOWER & & & & 50 & & \\
\hline INDUCTION FURNACE & & 3,000 & & 6 & 340 & \\
\hline MISCELLANEOUS & & & & 7 & & \\
\hline SUBTOTAL & & & & 93 & & \\
\hline \multicolumn{7}{|l|}{ GENERAL } \\
\hline COIP. $\# 1$ & & & & 125 & & \\
\hline COMP. \#2, 3 AND 4 & & & & 220 & & \\
\hline MISCELLANEOUS & & & & 11 & & \\
\hline SUBTOTAL & & & & 356 & & \\
\hline GRAND TOTAL & & & & 1,024 & 340 & \\
\hline & & & & & & \\
\hline
\end{tabular}


TABLE 6-V

DESCRIPTION AND FLOW RATES OF GAS-FIRED EQUIPMENT

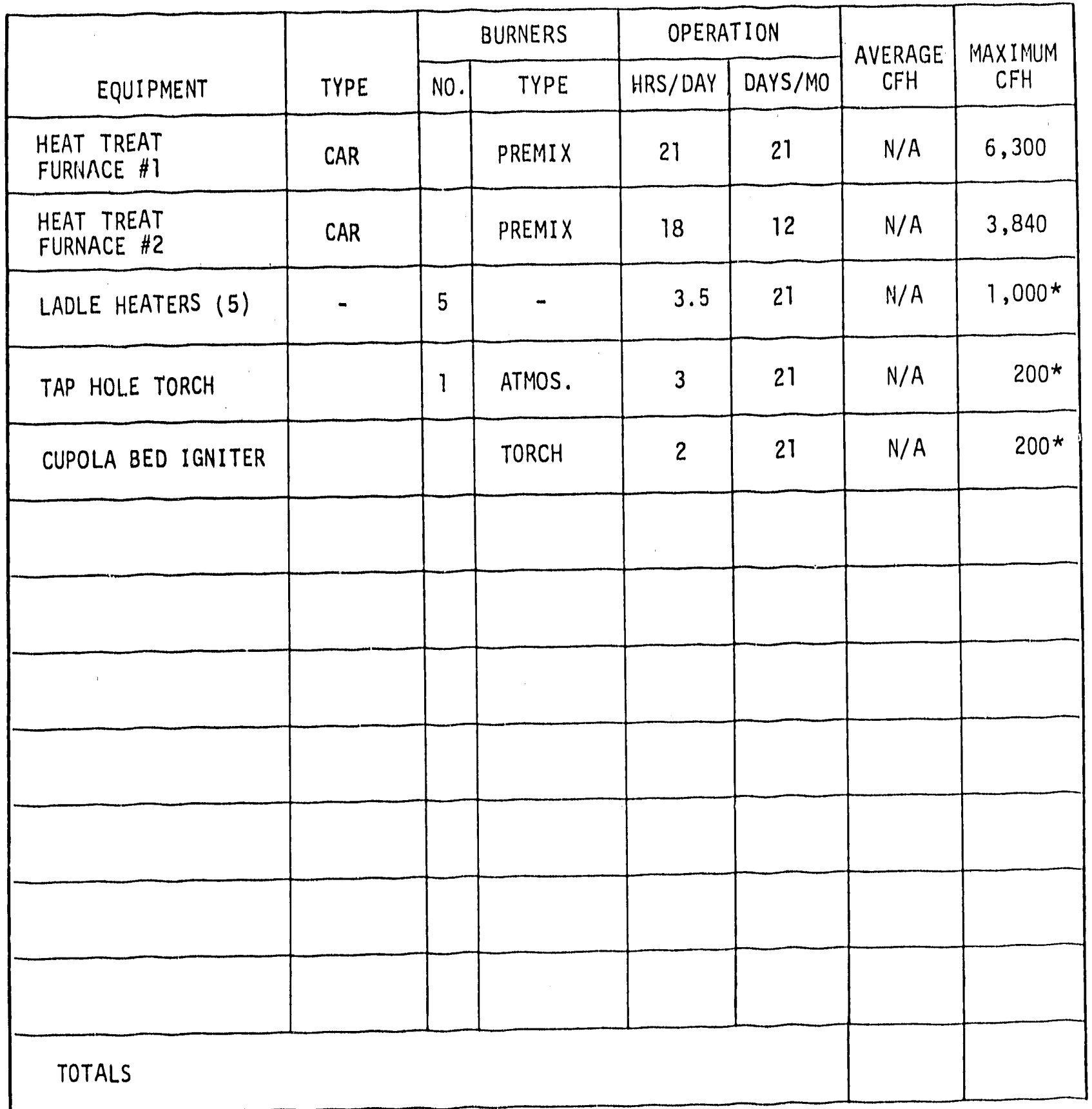

*ESTIMATED GAS USAGE. 


\section{ENERGY-EFFICIENCY RECORD}

MONTH OR YEAR RECORDED

UNITS OF PRODUCTION

YUEL costs

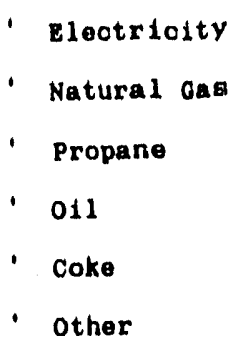

$1989 / 80$ Calendar Year

1.530

Net sood tons shipped

1

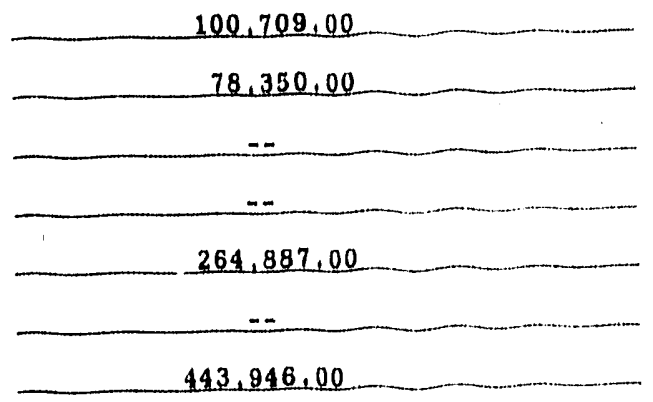

TOTAL

$\$$

$443,846,00$

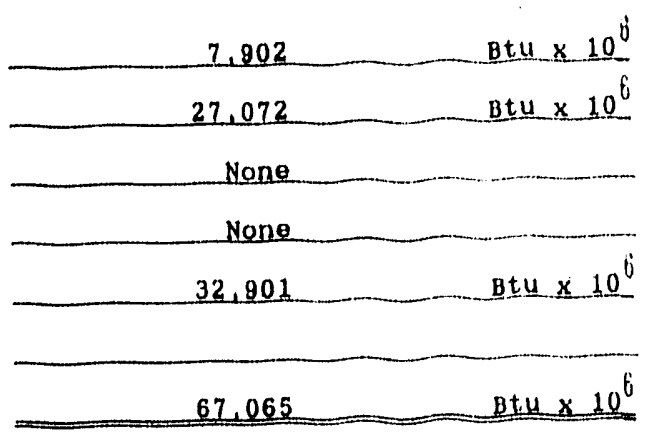

TOTAL BTU

RNERGY USED

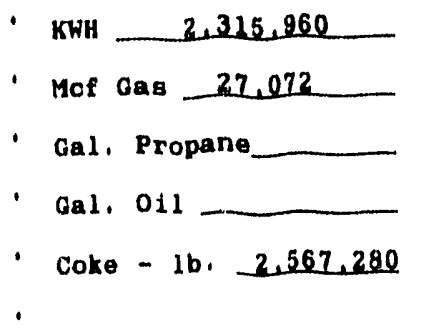

x 3,412 Btu $=$

$\times \quad 11$

$\times 91,600 \mathrm{Btu}=$

$\times 140,000$ Btu $=$

$\times 12,500$ Btu $=$

ENERGY USED PEH UNIT OP PRODUCTION

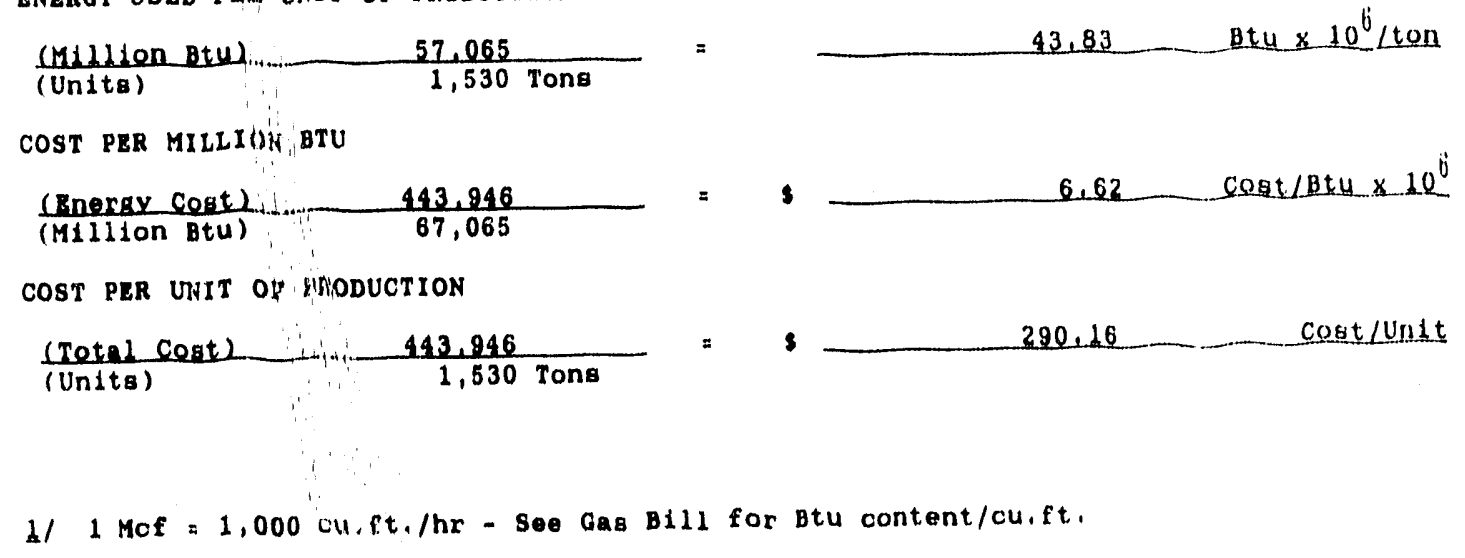


ENERGY-EFFICI ENCY RECORD 2/ 31

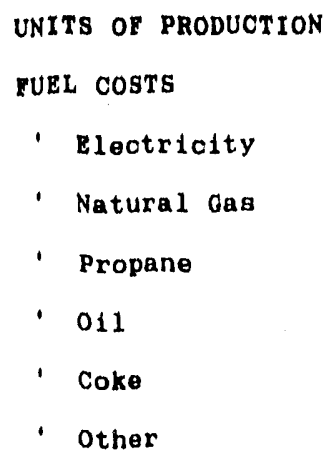

BNERGY USED

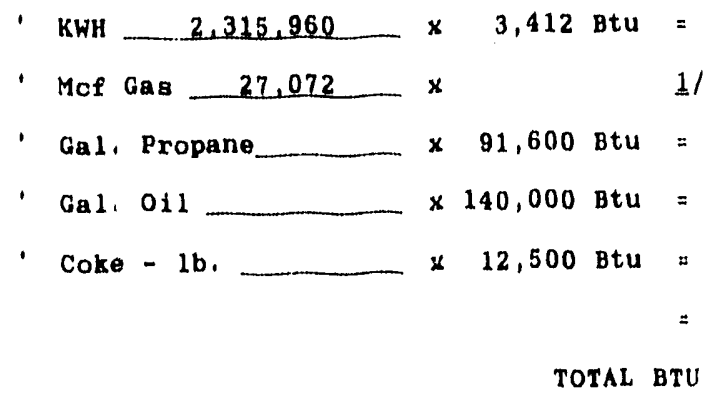

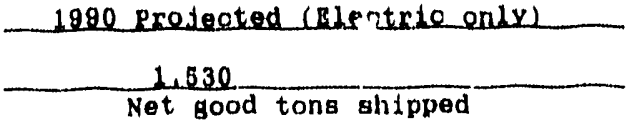

$\$$

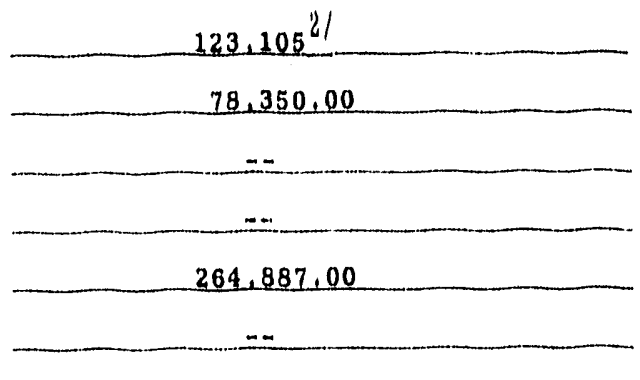

s 466,342

ENERGY USED PER UNIT OF PRODUCTION

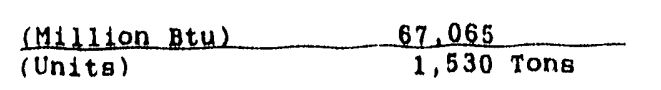

COST PER MILLION BTU

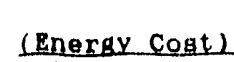
(Milion Btu)

$$
466,342
$$$$
67,065
$$

COST PER UNIT OF PRODUCTION

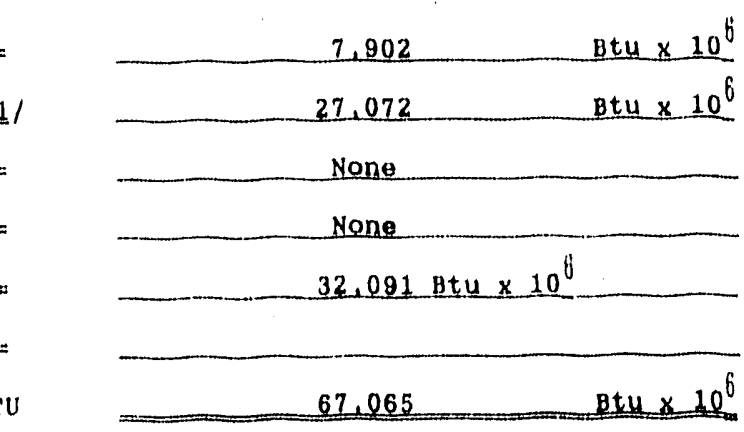

$43.83 .804 \times 10^{\circ}$

$\$$ $6.95 \quad \mathrm{cost} / \mathrm{B}+4 \times 10^{\circ}$ 304.79 cost/Unit

1/ 1 Mcf $=1,000 \mathrm{cu}, \mathrm{ft} \cdot / \mathrm{hr}-$ See Gas B1ll for Btu content/cu,ft,

2/ The electrical cost shown represents 1990 calendar year costs and are based on 1989 energy consumption with the new billing rates applied. The projected electrical cost is used as a base for calculating cost savings by implementation of demand control.

3/ All other energy costs are repregentative 1989 rates. 
TABLE 6-VIII

ANNUAL PRODUCTION

FOUNDRY CODE A

CASTING METAL DI \& GI

\begin{tabular}{|c|c|c|c|c|}
\hline PERIOD & MELT TONS & SHIPPED TONS & HEAT TREAT TONS & SALES VALUE \\
\hline JANUARY & 459.1 & 216.6 & $N / A$ & \\
\hline FEBRUARY & 285.6 & 142.3 & & \\
\hline MARCH & 152.0 & 44.4 & & \\
\hline APRIL & 382.1 & 147.8 & & \\
\hline MAY & 389.2 & 163.1 & & \\
\hline JUNE & 332.6 & 152.1 & & \\
\hline JULY & $N / A$ & 99.5 & & \\
\hline AUGUST & & 154.1 & & \\
\hline SEPTEMBER & & 77.8 & & \\
\hline OCTOBER & & 141.7 & & \\
\hline NOVEMBER & & $8 ? .7$ & & \\
\hline DECEMBER & 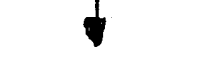 & 80.9 & $\checkmark$ & \\
\hline TOTALS & 3,890 & 1,530 & & $\$ 5,000,000$ \\
\hline
\end{tabular}

AVERAGE MELT TONS/DAY = 30.0

REPORTED \% SCRAP CASTINGS

14.17

REPORTED \% MELT LOSS

10.8

AVERAGE FOUNDRY YIELD \% 39.3

AVERAGE SALES VALUE/LB.

$\begin{array}{r}10.8 \\ \hline \$ 1.63 \\ \hline\end{array}$

*Melting on alternate days only 


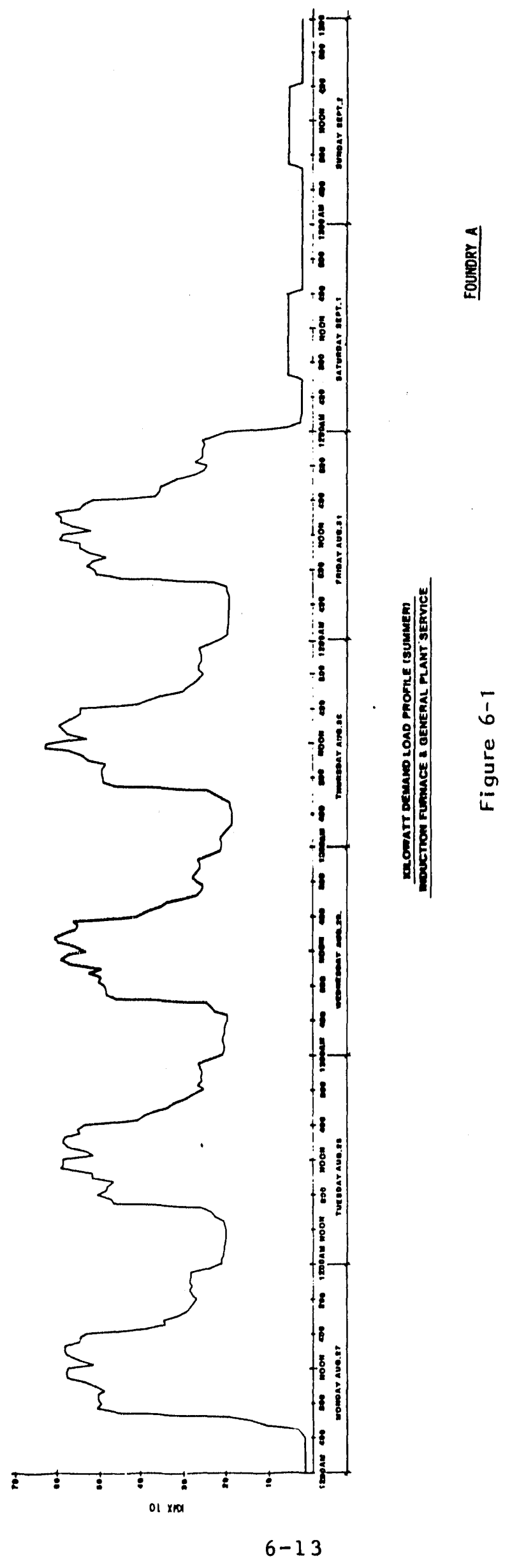


TABLE 6-IX

OPERATIONAL DATA FACT SHEET

HEAT TREAT FURNACES

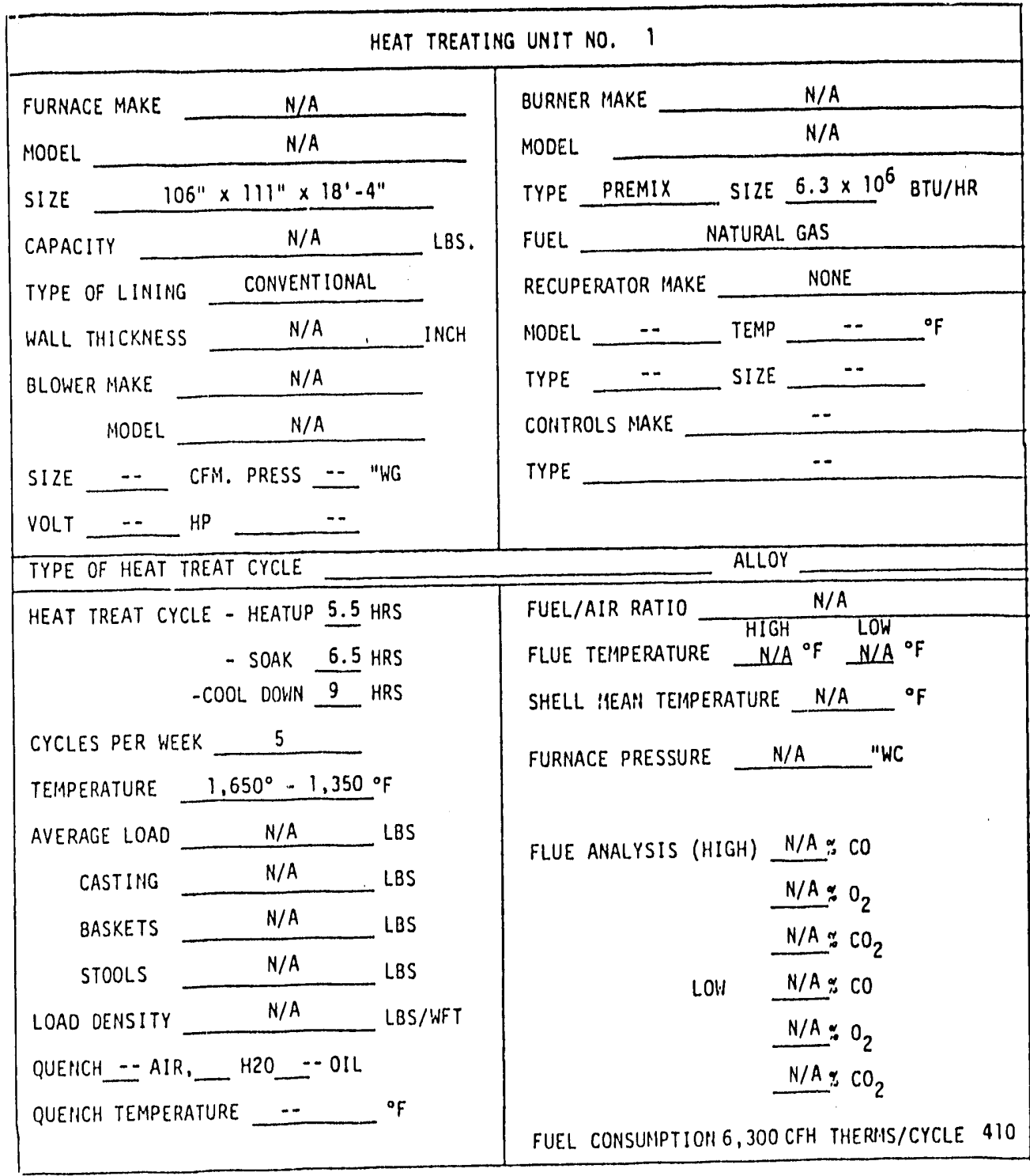

WALL AREA

878 SQ.FT.

WALL TENPERATURE HOT FACE $T_{1}$ WALL TEMPERATURE COLD FACE $T_{2}$ AMBIENT TEMPERATURE

$\frac{N / A}{N / A}{ }^{\circ} \mathrm{F} / A$

ENERGY COST/THERM $\&$ 0.3

HEAT TREAT LOADS/DAY

$N / A$

HEAT TREAT LOADS/YEAR

$N / A$ 
TABLE 6-IX (CONTINUED)

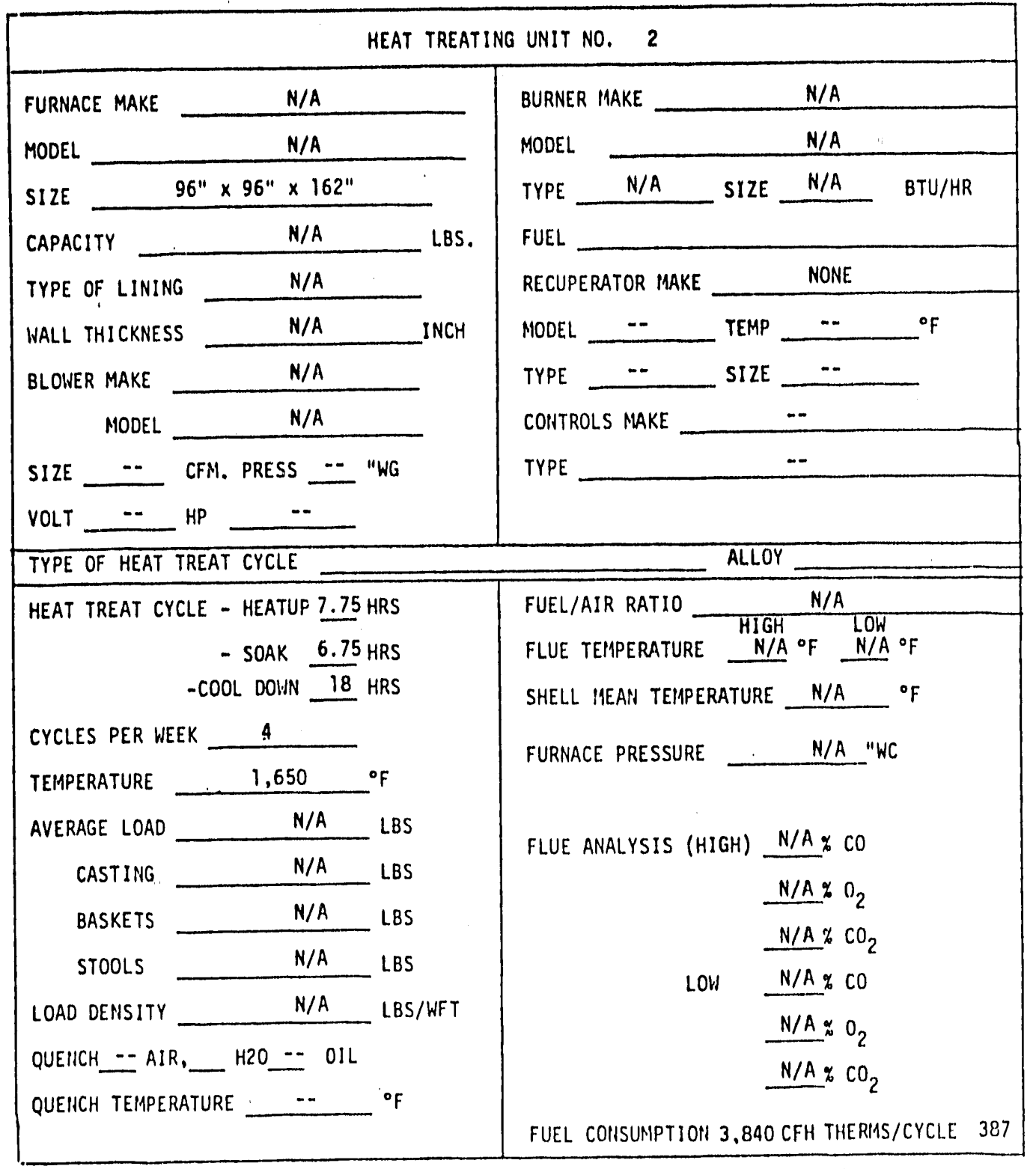

WALL AREA SQ.FT.

WALL TEMPERATURE HOT FACE $T_{1} \frac{N / A}{N / A}{ }^{\circ} \mathrm{F}$
WALL TEMPERATURE COLD FACE $T_{2}{ }^{\circ} \mathrm{F}$
AMBIENT TEMPERATURE

\begin{tabular}{l} 
ENERGY COST/THERH $\$ \frac{0.3}{N / A}$ \\
HEAT TREAT LOADS/OAY $\frac{N / A}{\text { HEAT TREAT LOADS/YEAR }}$ \\
\hline
\end{tabular}


TABLE 6-X

OPERAT IONAL DATA FACT SHEET

LADLE REHEAT DATA

\begin{tabular}{|c|c|c|c|}
\hline DLE CAP TONS & $N / A$ & HEAT CYCLES/DAY & $N / A$ \\
\hline \multirow{2}{*}{$\begin{array}{l}\text { LADLE AREA INSIDE } \\
\text { COVERED }\end{array}$} & $N / A$ & \multirow{2}{*}{$\begin{array}{l}\text { SQ FT. LINING THICKNESS } \\
\text { TYPE OF LINING }\end{array}$} & $N / A$ \\
\hline & No & & $N / A$ \\
\hline NSIDE TEMP & $N / A$ & \multirow[t]{2}{*}{ OUTER SHELL TEMP } & $\mathrm{N} / \mathrm{A}$ \\
\hline MBIENT TEMP & & & ${ }^{O} \mathrm{~F}$ \\
\hline GAS USAGE/HR & 200 & \multirow{2}{*}{$\begin{aligned} & \text { CU FT, } \mathrm{CO}_{2} \text { READING } \\
& \text { CFM } \text { PRESSURE } \\
&\end{aligned}$} & $N / A$ \\
\hline COMBUSTION AIR & $N / A$ & & $N / A$ \\
\hline PREHEAT CYCLE TIME & & \multirow{2}{*}{$\begin{array}{c}\text { HRS FLUE TEMP } \\
\text { RS VALUE } \\
\end{array}$} & $N / A$ \\
\hline REFRACTORY K VALUE & $N / A$ & & $N / A$ \\
\hline BLOWER HP & None & \multirow{3}{*}{$\begin{array}{l}\text { RECUPERATOR EFFCY } \\
\text { ANNUAL USE } \\
\end{array}$} & None \\
\hline COST/THERM \$ & 0.3 & & \multirow[t]{2}{*}{ BTU $\times 10^{6}$} \\
\hline OF. IINITS & & & \\
\hline
\end{tabular}

I/ Used 3.5 hours per day - 240 days per year. 
TABLE 6-XI

OPERATIONAL DATA FACT SHEET

CUPOLA DATA (TNO UNITS)

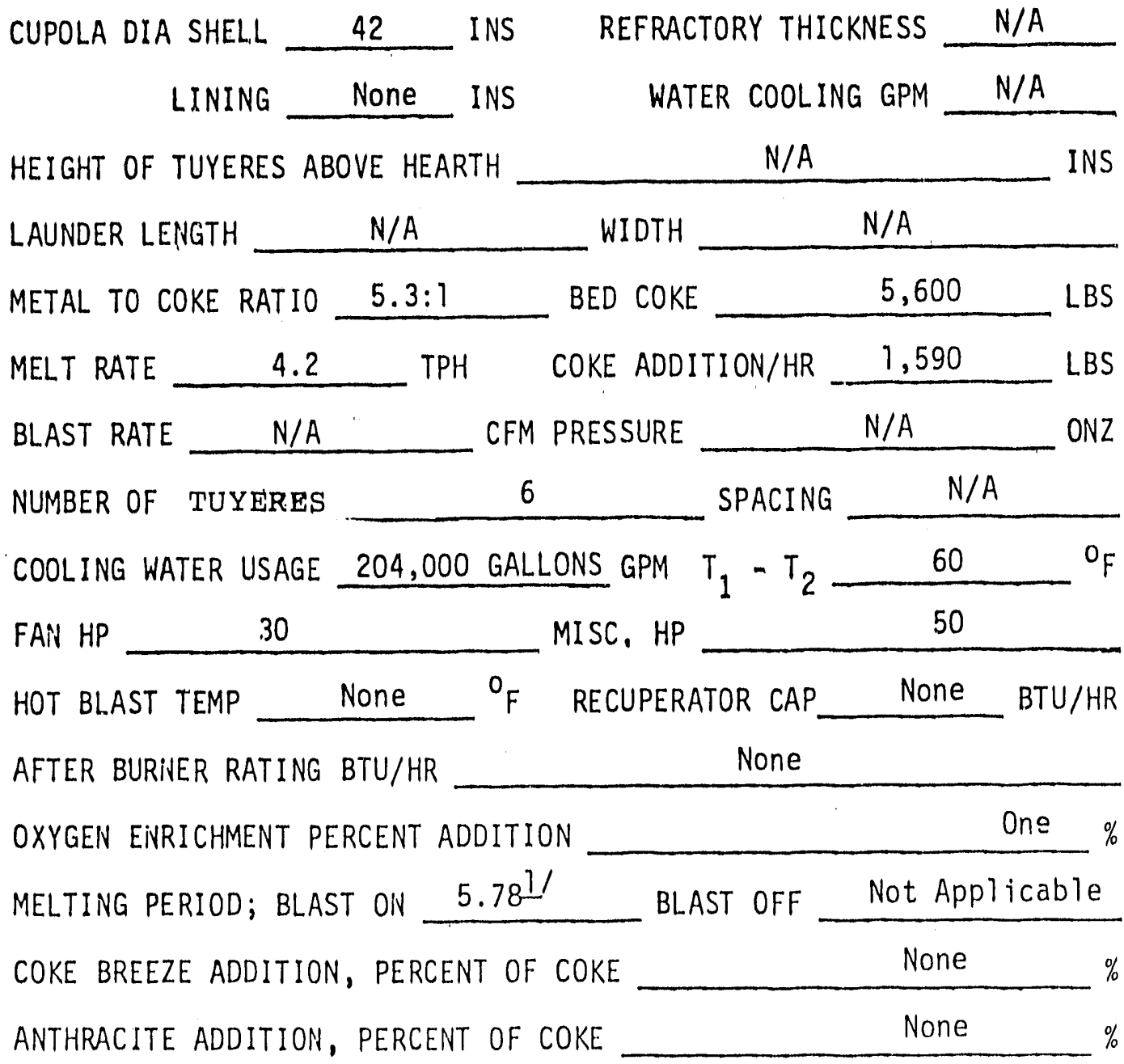

1/ Average figure. 
METHODOLOGY

As discussed throughout this study, certain input data is a prerequisite in calculating potential energy savings from different foundry processes. The lack of information pertaining to combustion air analysis and gas flow rates to varlous equipment precludes calculation of actual energy savings as 11lustrated in SECTION II of this study.

Potential energy savings for upgrading gas-fired equipment will be figured on a percentage basis; percentages used are conservative as compared to documented savings, from similax changes, as recorded by the Foundry Industry.

Electrical energy savings are factual. Calculations are based on actual kllowatts consumed by melt furnaces. Load profiles were developed from utility company computerized data for 15- to 30-minute periods. 


\section{ELECTRICAL ENERGY COST SAVINGS}

Electrical power cost savings can be realized by improved controls and changes in melting energy usage as calculated in the following work sheets.

Based on a sample bllling period of one year, the cost reduction potential 18:

1. Demand Contro1

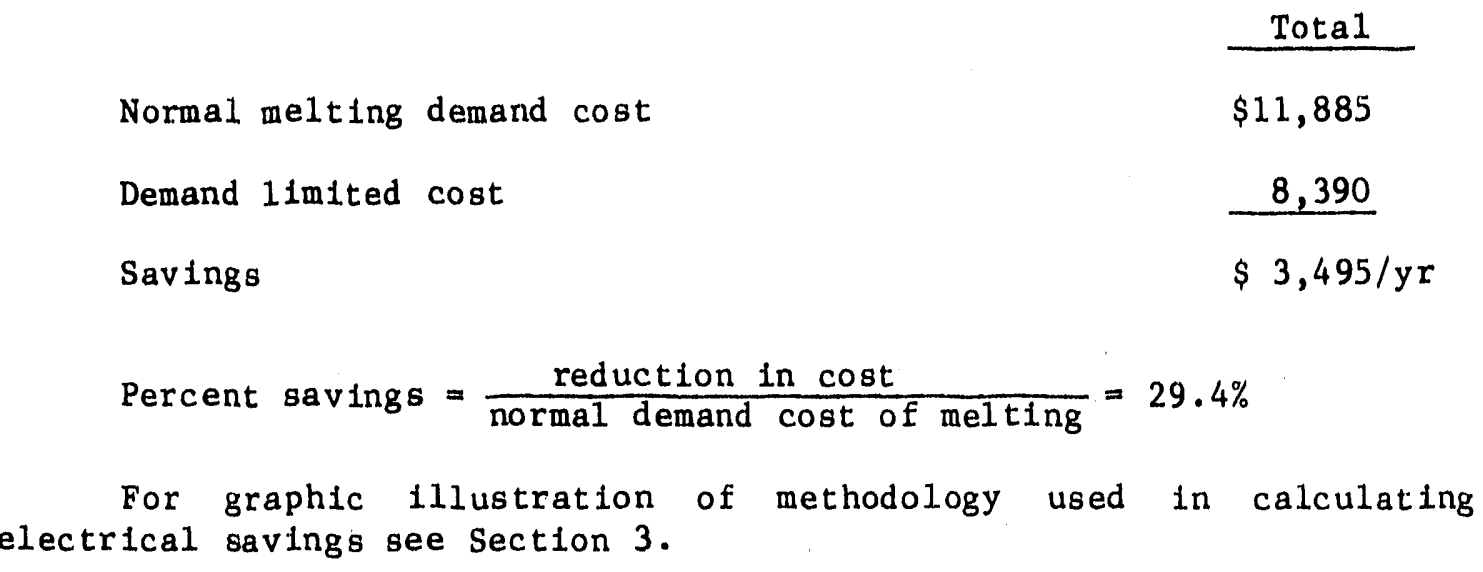


The following approximate cost savings can be realized by the installation of demand limiting controls. Controlling the Peak Kllowatt demand to 350 kilowatts.

Potential Cost Savings $=\$ 130$ per month Annual Cost Savings $=\$ 1,670$

For graphic illustration of methodology used for calculating cost saving see drawing below.

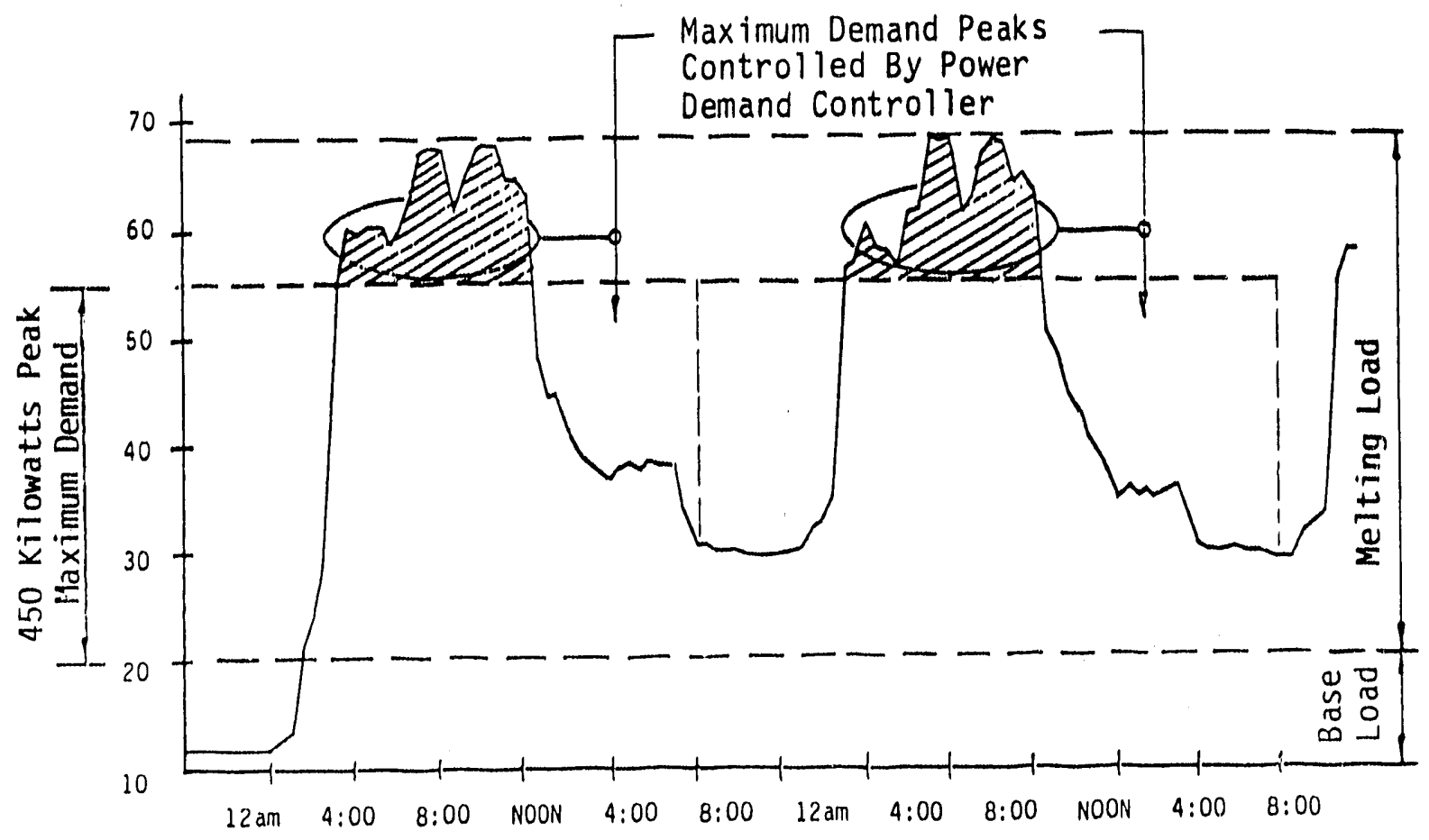

FIGURE 6-2. KILOWATT DEMAND LOAD PROFILE INDUSTRIAL BILLING RATE 
TABLE 6-XII

DEMAND CONTROLLING

\begin{tabular}{|c|c|c|c|c|c|c|}
\hline \multicolumn{3}{|c|}{ NORMAL MELTING COST } & \multicolumn{4}{|c|}{ DEMAND CONTROLLING COST } \\
\hline Month & $\begin{array}{l}\text { Kilowatt } \\
\text { Demand }\end{array}$ & $\begin{array}{l}\text { Demand } \\
\text { Charge }\end{array}$ & $\begin{array}{l}\text { Kilowatt } \\
\text { Demand }\end{array}$ & $\begin{array}{l}\text { Demand } \\
\text { Charge }\end{array}$ & Savings & $\%$ \\
\hline Jan. & 512 & $\$ 994.24$ & 350 & $\$ 699.4$ & $\$ 294$ & 29.6 \\
\hline Feb. & 513 & 996.06 & & & 296 & 29.7 \\
\hline March & 499 & 970.58 & & & 271 & 27.9 \\
\hline April & 505 & 981.50 & & & 282 & 28.7 \\
\hline May & 511 & 992.42 & & & 293 & 29.5 \\
\hline June & 518 & $1,005.16$ & & & 306 & 30.4 \\
\hline July & 508 & 986.96 & & & 288 & 29.2 \\
\hline Aug. & 503 & 977.86 & & & 278 & 28.5 \\
\hline Sept. & 500 & 990.60 & & & 291 & 29.4 \\
\hline oct. & 514 & 997.88 & & & 298 & 29.9 \\
\hline Nov. & 513 & 996.06 & & & 297 & 29.8 \\
\hline Dec & 513 & $\frac{996.06}{\$ 11,885}$ & i & $\frac{1}{\$ 8,390}$ & $\frac{297}{3,495}$ & 29.8 \\
\hline
\end{tabular}

Potential yearly saving (average) $=29.4 \%$

Based on a maximum demand of $350 \mathrm{kw}$. 
Upgrading Heat Treat Furnaces

Amount of total gas consumed

$=\quad 270,724$ therms/yr

Total natural gas cost

$=\$ 78,350.00$

Average cost per therm

$=\$$

0.289

Maximum gas usage per hour:

Heat Treat Furnace \#1

- 6,300 cu. ft.

Heat Treat Furnace \#2

- $\quad 3,840 \mathrm{cu}$. ft.

Total

$\square$

$10,140 \mathrm{cu} \cdot \mathrm{ft}$.

Average heat-up time (Total)

-

13.25 hours

Average holding time (Total)

$=\quad 13.25$ hours

Total cycles per year

$=\quad 150$

Assume yearly gas consumption attributed to heat treat operations 1s $80 \%$ of total plant gas input of $(270,724 \times 0.8) 216,000$ therms/yr.

Approximately $56 \%$ energy savings can be reallzed by:

- Installing ceramic fiber lining - 12-inch thick

- Upgrading burner system and controls

- Adding combustion alr preheating

Energy saved $=216,000$ therms $\times 0.56=120,960$ therms/yr

Cost savings $=120,960$ therms $\times 0.289=\$ 34,957.00$ 


\section{Upgrading Ladle Heaters}

Quantity of ladle heaters used at one time $=5$

Hours of operation per year

$-882 \mathrm{hrg} / \mathrm{yr}$

Assumed average gas consumption

$=1,000 \mathrm{cu} \cdot \mathrm{ft} . / \mathrm{hr}$

Total gas used per year:

$(1,000 \mathrm{cu} . \mathrm{ft} \cdot / \mathrm{hr} \times 882 \mathrm{hrs})$

- $882,000 \mathrm{cu} \cdot \mathrm{ft} \cdot / \mathrm{yr}$

OR

8,820 therms

Approximately $40 \%$ energy savings can be reallzed by:

- Upgrading 1InIng

- Installing ladle covers

- Upgrading burner system

Energy saved $=8,820$ terms $\times 0.4$

3,528 therms

Cost savings $-3,528$ therms $\times 0.289$

$=\$ 1,020.00$ 
Amount of coke consumed

Total cost of coke

Average cost per ton

Cupola size diameter

Cupola melt rate Tons/Hour

Total tons melted/Year

Metal to coke ratto (charged)

Spectal conditions $-0_{2} \%$

Energy (coke) savings can be reallzed by:

- Hot blagt conditioning

- Divided blast supply

Energy savings (charged coke only) =
$22.8 \%$

$26.2 \%$

$49.0 \%$

\footnotetext{
$$
\frac{3,000 \text { melt tons }}{(5.3: 1) \text { coke usage/ton }} \times \quad 0.49=277 \text { tons }
$$

Cost savings $=277$ tons $x \$ 206.35-\$ 57,160 /$ year
}

\section{CONVERT TO ELECTRIC MELTING}

Replacement of cupola melting with electric furnace melting involves consideration of multiple varlables which occur in foundry operation. An in-depth analysis is necessary to carry out a complete analysis and is not covered in this report. 


\section{ECONOMIC ANALYSIS}

Payback perlod 1s calculated as follows:

Tota1 Cap1ta1 Investment Gross Energy Cost Reductions/Year

- Years

Payback years for individual profects are 11sted in PART $G$ based on order of magnitude costs as follows:

- Demand Controller

- Upgrading Heat Treat Furnaces

- Upgrade Ladle Heaters

- Upgrading Cupola

$$
\begin{array}{r}
\$, 000 \\
80,000 \\
12,000 \\
250,000 \\
\hline
\end{array}
$$

TOTAL

The following conditlons could lower the anticlpated payback perfod constderably:

- Present day equipment costs used. However, the energy cost savings is based on 1989 calendar year average energy cost, except for electrical energy which is escalated to show approxImate 1990 costs.

- No credit taken for government tax credit for installation of energy-savings devices.

- Calculation of return on Investment ut1lizing life-cycle testing methods, which take into account depreclation, cost of money, and escalation of energy cost over the 11 fetime of the equipment, could possibly make the capital investment attractive. 
SIMMAARY TABULATION

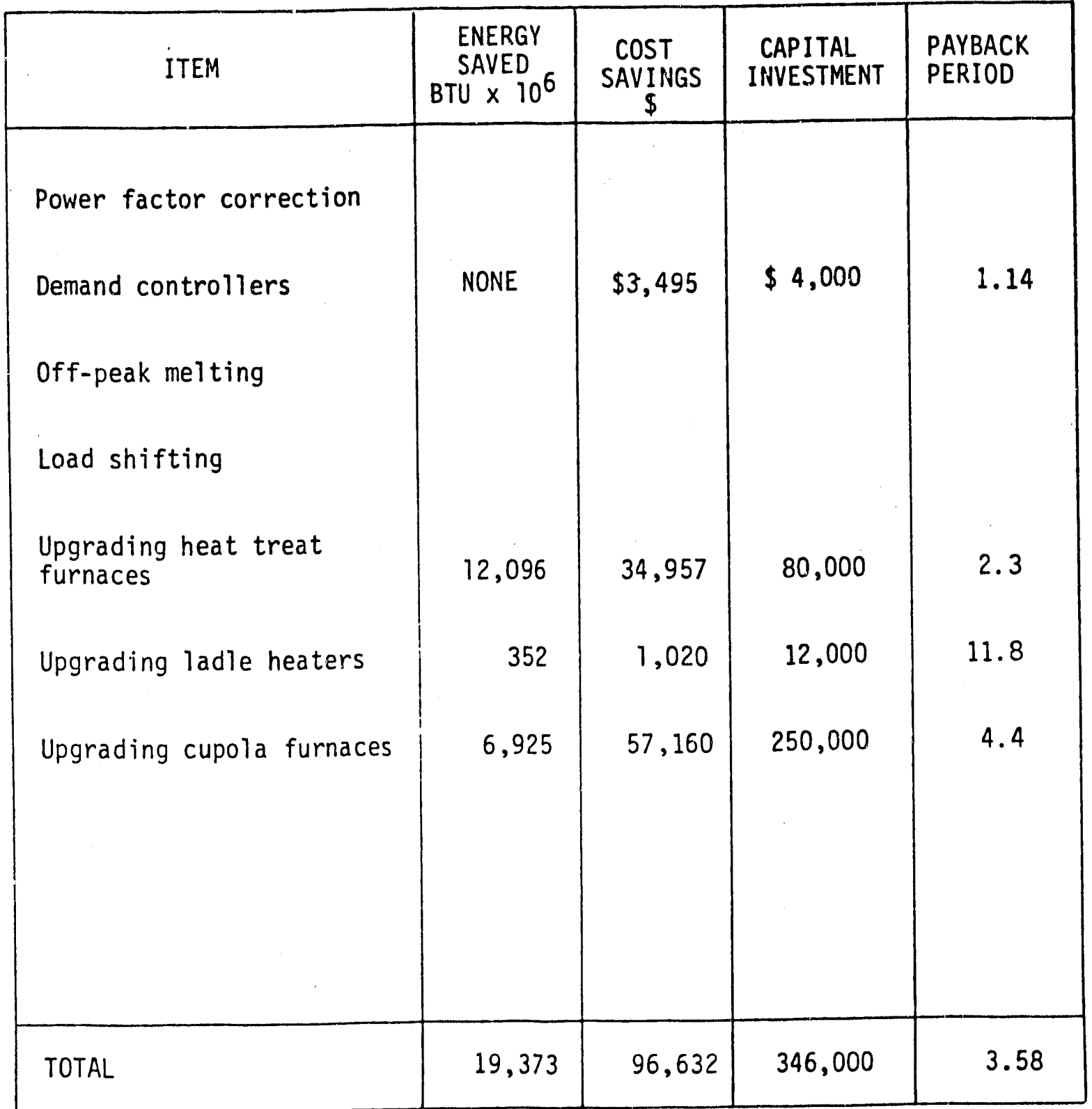

Total Btu reduction/ton of castings shlpped

$=\frac{19,373 \times 10^{6}}{1,530}=12.66 \times 10^{6} \mathrm{BIU}$ 
MONTH OR YEAR RECORDED

UNITS OF PRODUCTION

PUEL Costs

- Electricity

- Natural Gas

- Propane

- 011

- Coke

- other

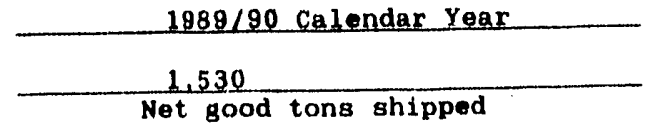

$\$$

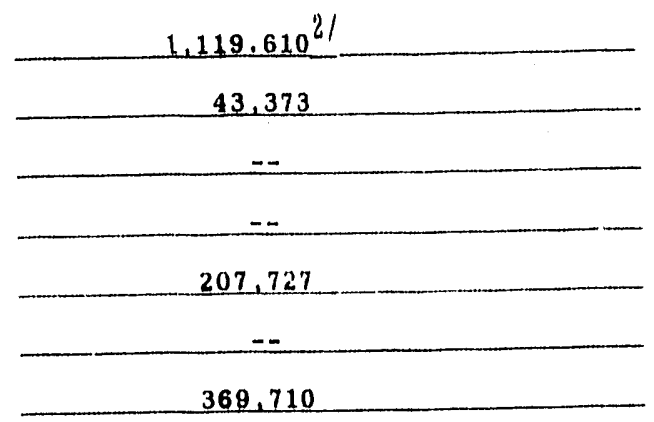

TOTAL

s 369,710

BNERGY USED

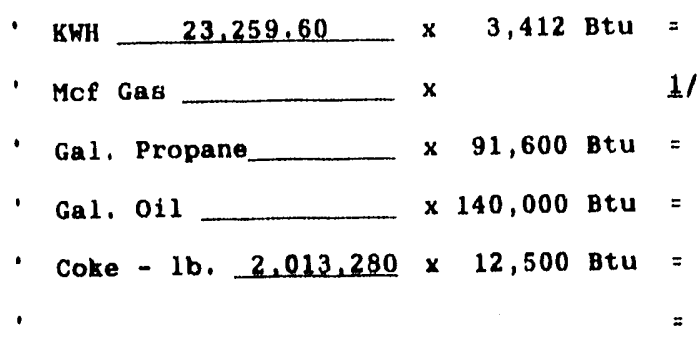

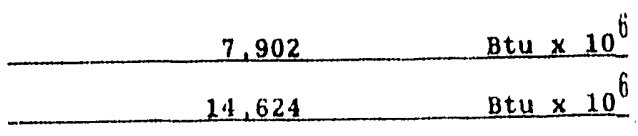

1

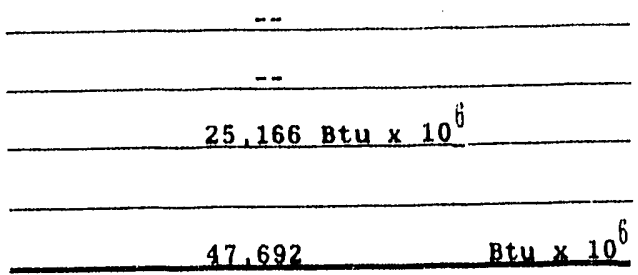

TOTAL BTU

ENERGY USBD PER UNIT OP PRODUCTION

$\begin{array}{ll}\text { (Million Btu } & 47,692 \\ \text { (Units) } & 1,530 \text { Tons }\end{array}$

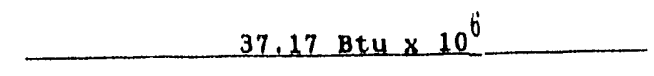

COST PER MILLION BTU

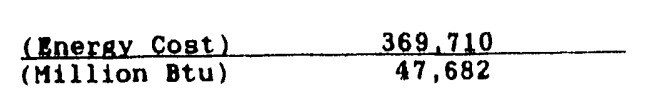

$\$-7.75 \quad \operatorname{Cos} t /$ Bty $\times 10^{6}$

COST PER UNIT OF PRODUCTION

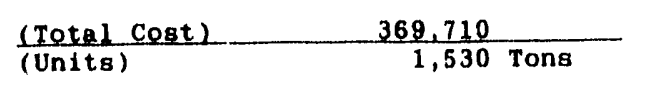

s

241.6 Cost/Unit

1/ 1 Mcf $=1,000 \mathrm{cu}, \mathrm{ft} . / \mathrm{hr}$ - See Gas Blll for Btu content/cu.ft.

2/ Electrical cost based on representative 1990 billing rates

\section{ALTERNATE 1}



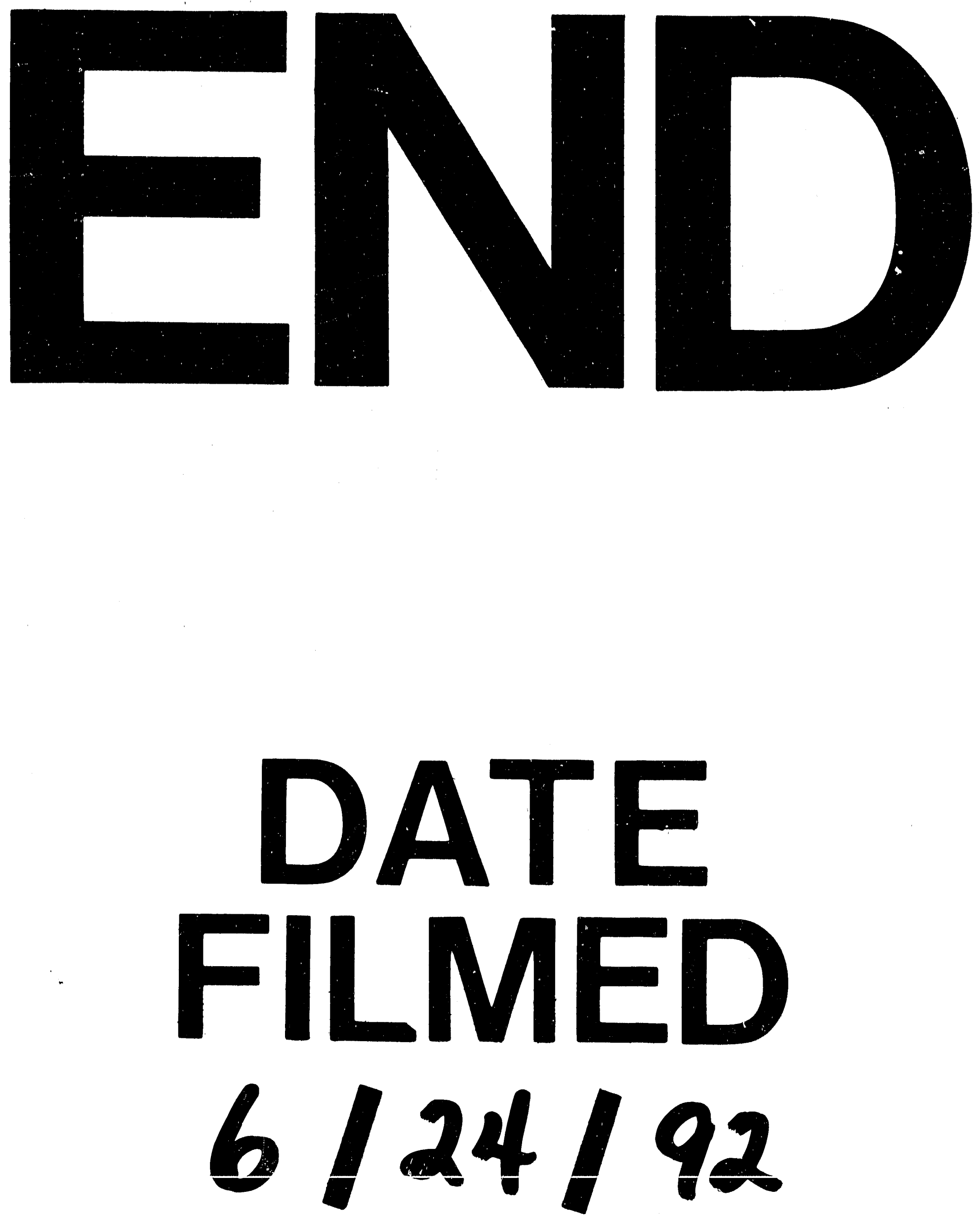
